\title{
The History of and Prospects for Public Sector Reforms in Sri Lanka
}

\author{
By
}

Ranjanee Kusumsiri De Alwis

\begin{abstract}
A thesis
submitted to the Victoria University of Wellington in fulfilment of the requirement for the degree for

Doctor of Philosophy in Public Policy
\end{abstract}

Victoria University of Wellington

2009 


\section{Abstract}

Public sector ${ }^{1}$ reform is about improving the management of the public sector. Such reform has no universal framework. What can be done in any country is a product of its history, structure and culture. Moreover, public sector reform is not simply simple 'technical' change. It depends upon, and actually comprises reform of a nation's political system.

The main focus of this thesis is administrative reform in Sri Lanka (SL). The key research question is why this has encountered so many problems in the SL public administration system despite many attempts at reform since 1950. And, why and how have key historical, structural, sociological economic and political factors since Independence contributed to this current impasse?

Answers to key questions investigated were sought through qualitative and quantitative research. Using a combination of official documents and interviews with senior political elites, public officials and academics, this thesis analyses the current situation of public administration in SL. In order to better understand the current situation, the history of public administrative reform in SL is investigated. The focus of the analysis lies in understanding the complexity and specificity of the present situation in order to better assess prospects for future reforms. This provides a backdrop to effective future agendas and highlights issues in the present system that must be addressed within that agenda. In this process this thesis examines when, how and why administrative reforms took place in SL since the 1950s, which political parties were in power, and who gained and lost due to reforms. The, Administrative Reform Committee Reports (ARC) of 1986/88 are central to this analysis because they made comprehensive recommendations on all aspects of administrative reform. The experience of the ARC carries valuable lessons to administrative reformers.

\footnotetext{
${ }^{1}$ Public sector includes : Government and the Organs of State (Organs of State includes Presidential Secretariat, Legislature, Public Service Commission, Police Service Commission, Commission to Investigate Allegation of Bribery and Corruption, Attorney General Department, Auditor General Department, Finance Commission and Salaries and Cadre Commission) and Public Enterprises.
} 
Because this thesis is exploring historical and political questions, the Pollitt and Bouckaert model of public management, which focuses on historical institutionalism, is used as the theoretical framework.

This thesis finds that all reforms in SL from 1950-2005 were isolated, ad hoc, and reactive to crisis situations, not proactive. On many occasions such changes lacked adequate examination as to their effects on the administrative system as a whole. This further resulted in more problems and even greater complexity, with the ARC recommendations not fully implemented. This thesis analyses underlying factors responsible for thwarting efforts to create an effective and efficient public administration system in SL.

The originality and significance of this thesis lies in two areas: (a) it is the first systematic historical analysis of public sector reform in SL that pulls together a wide range of evidence from divers sources; (b) this thesis confirms the importance of understanding the history and political dynamics of a country before serious and wholesale attempts at public sector reform are attempted. I hope that future SL reformers will be able to learn the lessons of history in that respect.

This thesis concludes that this state of affairs remains a product of complex interactions of many different historical, social, political, and cultural conditions. Therefore, this thesis argues, any future programme of reform must take full account of those specifics. 


\section{Acknowledgements}

During the past 42 months a number of people assisted me in completing this $\mathrm{PhD}$ thesis in various ways. They all deserve thorough acknowledgement.

Firstly, I would like to express my sincere gratitude to my two supervisors A/Professor (Dr) Bill Ryan and Mr. Rob Laking for their excellent direction, guidance and encouragement throughout this research. Their critical comments and suggestions are the strengths of this research product. They have also been very supportive beyond my academic life and a consoling source in all difficult times. The completion of this study would not have been possible without their thoughtful scholarship which steered me on the right track. My heartfelt respect, gratitude, and best wishes are due to both of them.

I am also grateful to the New Zealand Government (NZAID) for awarding me a scholarship to study in Victoria University of Wellington. I also would like to thank the School of Government staff, Victoria University of Wellington for providing me necessary resources including financial assistance for my field work and the conference in Fiji. Many thanks go to Dr. Deborah Laurs, Senior Adviser, Student Learning Support Service, for excellent support. I also extend my thanks to Ms. Janet Keilar, Commerce Librarian for retrieving books from Sri Lanka and other countries on my request and Ms. Kamy Ooi, Subject Librarian, and Mr. Victor Lipski, Law Librarian, for assisting me with the references.

I also would like to thank Dr. (Mrs) Hanifa Koya and her staff at the Wakefield Hospital for their efficient and excellent service during my stay in the hospital. This enabled me to recover early from my health problems and complete this thesis in time.

I would also take this opportunity to thank the Government of Sri Lanka for granting me study leave. Many thanks go to key respondents who were willing to participate in the narrative enquiry of this research (all respondents are listed in Appendix 3). Thanks also go to my friend Sanath Perera, Director, External Resources Department of the Treasury for sending me updated information from time to time. I also thank my friends J. M. Karunadasa, Senior Assistant Secretary, Ministry of Public Administration, Jinasiri Dadallage, Director, Public Service Training Institute, P. 
Sumanapala, Director, National Planning Department, and Seetha Fernando, Accountant, Ministry of Provincial Councils and Local Government for their kind support during my field work.

I also would like to take this opportunity to thank Dr. B.S.Wijeweera, former Civil Servant, for providing me necessary materials and participating in the narrative enquiry in this thesis. My thanks also go to him for proof reading and editing the thesis. His kind support is very much appreciated. Any mistakes that remain yet are mine.

At last but not least, I extend my deepest gratitude to my family, husband - Nelson De Alwis, and two sons, Kamal and Gihan, and daughter, Madushi. Without their love and support this research may never have been completed.

In particular, this thesis is dedicated to my late parents, Mr. D.C. Weragoda Arachchi and Mrs. A. Weerasinghe Pathirana, and my eldest sister, Mrs. S. Weragoda Arachchi and her late husband, Mr. Yasapala Edirisooriya, who have taught me the value of education and provided me with inspiration. I owe an enormous debt to them. 


\section{Abbreviations}

AAT

ADB

AG

AIS

ARC

BOI

CA

CBSL

CC

CEB

$\mathrm{CH}$

COPA

COPE

DDCs

DDCs

DSs

FRs

FMRP

GAs

HOD

ICTA

IMF

JSC

JVP

LTTE

$\mathrm{MC}$

MCs

MPs

NARC

NPM
Administrative Appeal Tribunal

Asian Development Bank

Auditor General

All Island Services

Administrative Reforms Committee

Board of Investment

Court of Appeal

Central Bank of Sri Lanka

Constitutional Council

Ceylon Electricity Board

Chief Headman

Committee on Public Accounts

Committee on Public Enterprises

District Development Councils

Divisional Development Councils

Divisional Secretaries

Financial Regulations

Fiscal Management Reform Programme

Government Agents

Head of Department

Information and Communication Technology Agency

International Monetary Fund

Judicial Service Commission

Janatha Vimukthi Peramuna

Liberation Tigers of Tamil Eelam

Mahinda Chintana

Municipal Councils

Members of Parliament

National Administrative Reforms Council

New Public Management 


$\begin{array}{ll}\text { NPS } & \text { National Productivity Secretariat } \\ \text { NPC } & \text { National Police Commission } \\ \text { NPSC } & \text { National Public Service Commission } \\ \text { OECD } & \text { Organisation for Economic Co-operation and Development } \\ \text { PA } & \text { Performance Appraisal } \\ \text { PCs } & \text { Provincial Councils } \\ \text { PEs } & \text { Public Enterprises } \\ \text { PPS } & \text { Provincial Public Service } \\ \text { PPSCs } & \text { Provincial Public Service Commissions } \\ \text { PSs } & \text { Pradeshiya Sabhas } \\ \text { SAP } & \text { Structural Adjustment Reform Programme } \\ \text { SC } & \text { Supreme Court } \\ \text { SEMA } & \text { Strategic Enterprises Management Agency } \\ \text { SL } & \text { Sri Lanka } \\ \text { SLAS } & \text { Sri Lanka Administrative Service } \\ \text { SLIDA } & \text { Sri Lanka Institute of Development Administration } \\ \text { SLFP } & \text { Sri Lanka Federal Party } \\ \text { SLPS } & \text { Sri Lanka Public Service/Public Sector } \\ \text { SLRs } & \text { Sri Lanka Rupees } \\ \text { UCs } & \text { Urban Councils } \\ \text { UNDP } & \text { Village Headman Nations Development Programme } \\ \text { UNP } & \text { VH }\end{array}$




\section{Table of Contents}

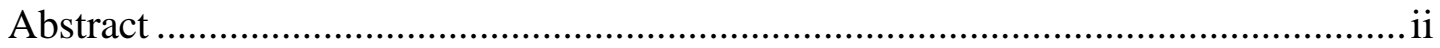

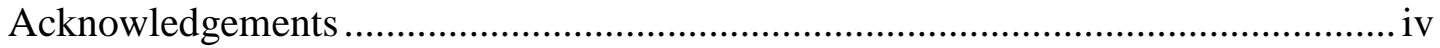

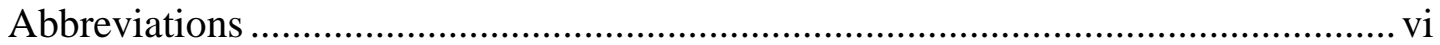

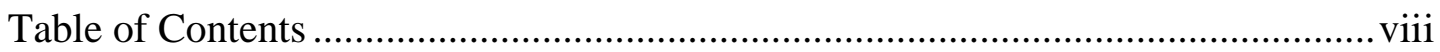

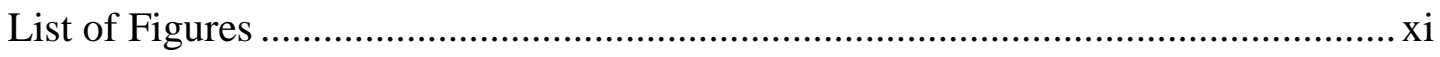

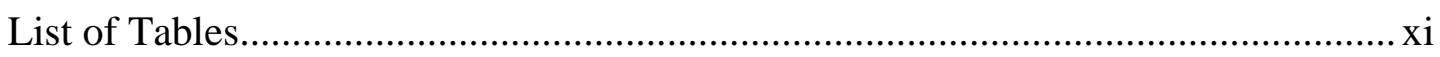

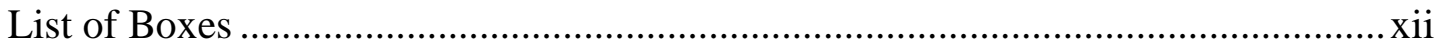

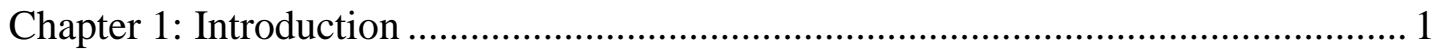

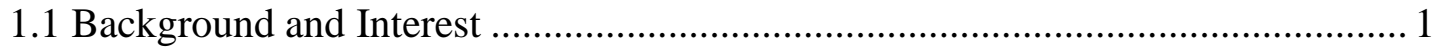

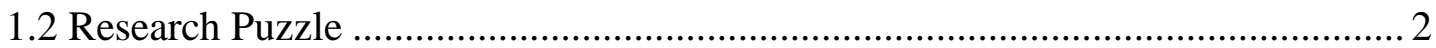

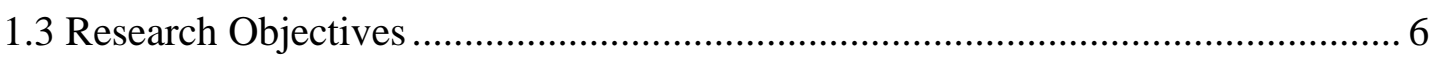

1.4 Main Focus and Research Questions ............................................................ 7

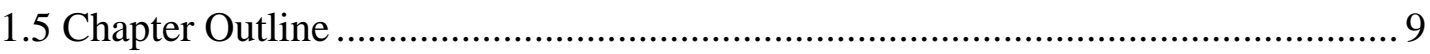

Chapter 2: Conceptual Framework and Methodology ............................................ 12

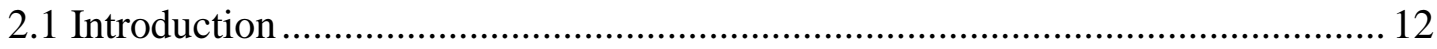

2.2 Historical vs. Rational Choice Approaches, and a Rationale for Adopting the Former 13

2.3 Generic Prescription and Policy Transfer Approaches ...................................... 16

2.4 Historical Institutionalism: Pollitt and Bouckaert.............................................. 20

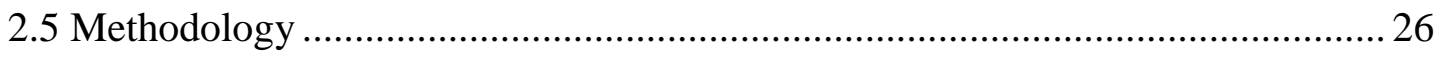

Chapter 3: Structure and Process of Government .................................................... 36

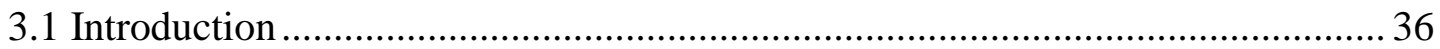

3.2 Current Composition and Structure of Government …...................................... 36

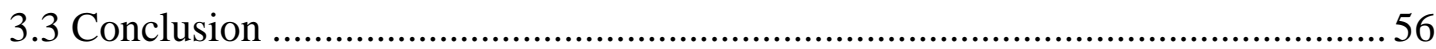

Chapter 4: The Current Situation of

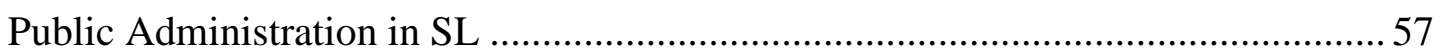

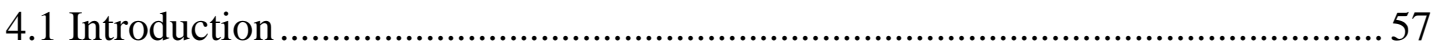

4.2 Part I: Scope of Public Administration, Structural and Service Delivery Problems, Positive Aspects of SL's Public Administration and Public Enterprises.. 58

4.3 Part II: Public Service Cadres, Cost \& Personnel Management ........................... 94

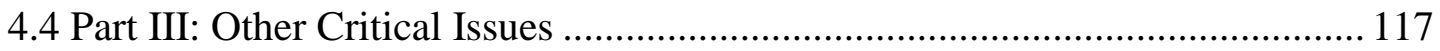

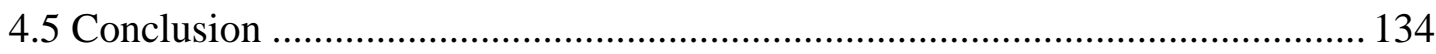


Chapter 5: Public Sector Reforms in Sri Lanka from 1950- 2005. 136

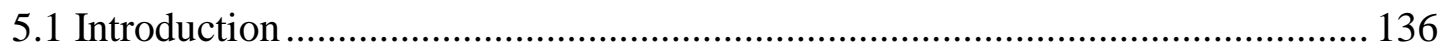

5.2 Part I: The Reforms During the 1950s and 1960s............................................. 137

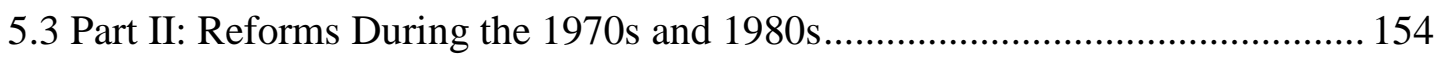

5.4 Part III: Reform Initiatives from 1990 to 2000 ...................................................... 194

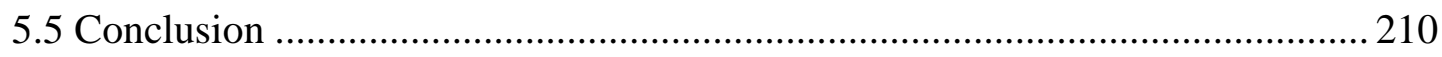

Chapter 6: Review of the Administrative Reform Committee (ARC) Report of

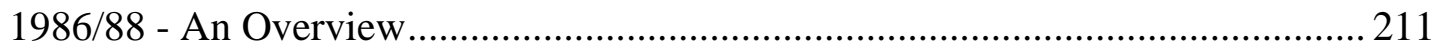

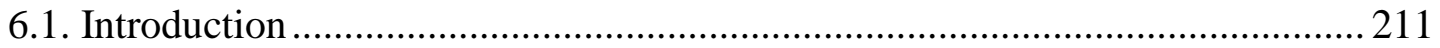

6.2 Why ARC and How it Came into Being? ...................................................... 213

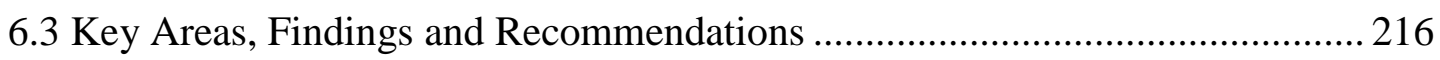

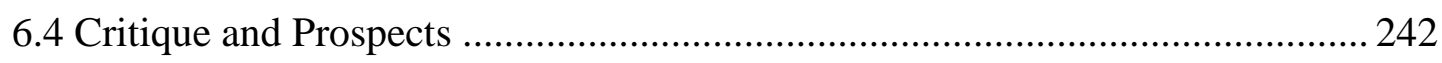

6.5 Why were ARC Recommendations not Fully Implemented? ........................... 244

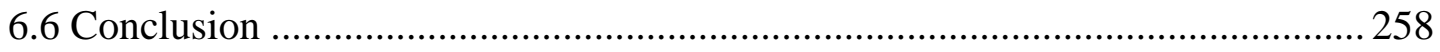

Chapter 7: Study Findings and Future Prospects .................................................. 260

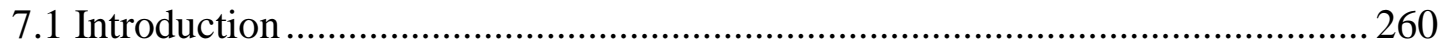

7.2 Applicability of the Pollitt and Bouckaert Analytical Model ........................... 260

7.3 Revision of Pollitt and Bouckaert Model of Public Management ................... 268

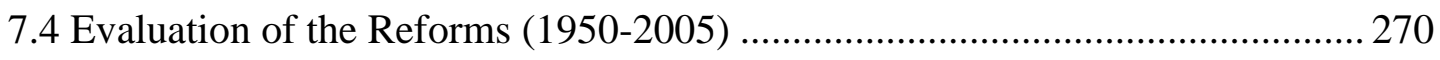

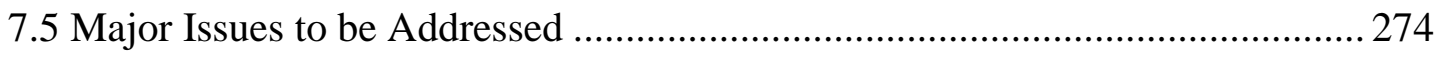

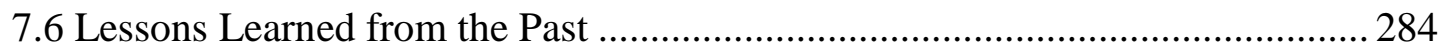

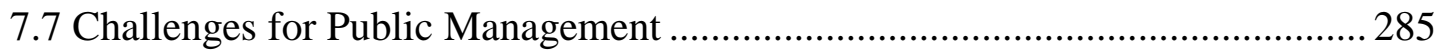

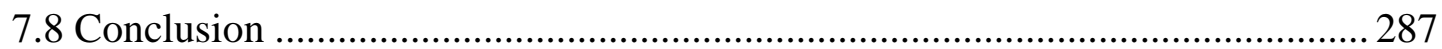

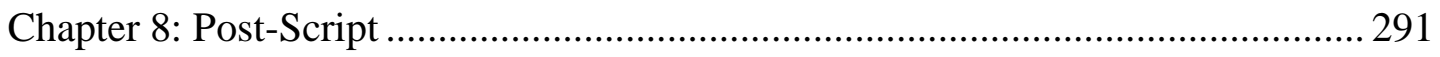

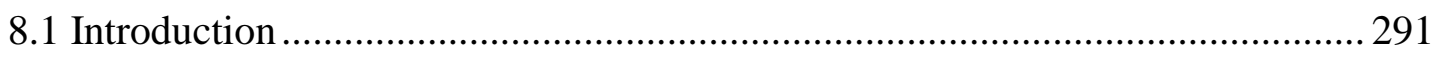

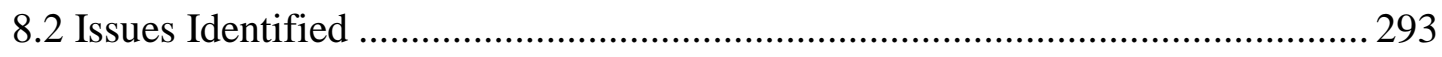

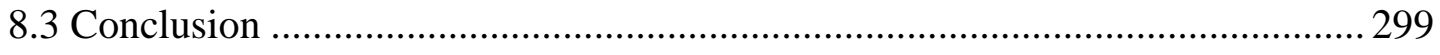

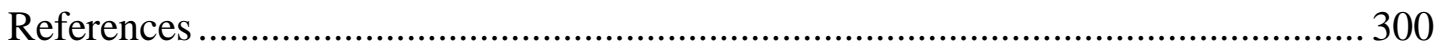

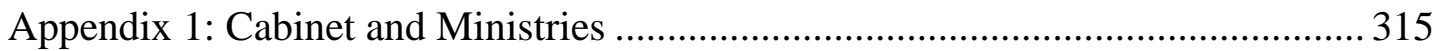

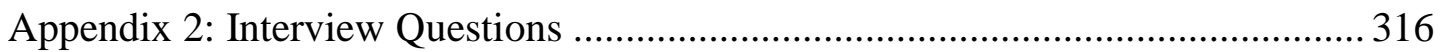

Appendix 3: Interviewees (in alphabetical order) ................................................ 319

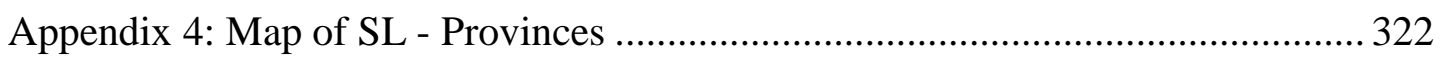

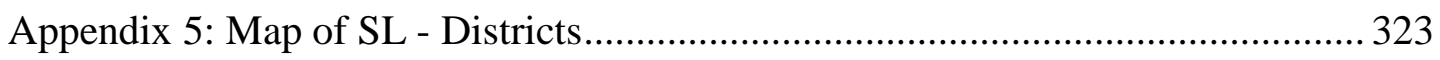

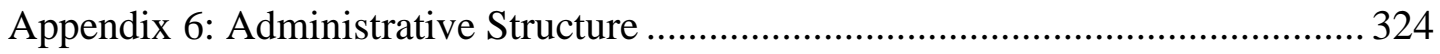


Appendix 7: Delegation of Authority of the National Public Service Commission 325

Appendix 8: ARC Recommendations Implemented Fully or Partially

Appendix 9: ARC Recommendations Not Implemented... 328 


\section{List of Figures}

Figure 1: Pollitt and Bouckaert Conceptual Model 21

Figure 2: The Process of Public Accountability 43

Figure 3: Financial Releases by the Treasury to PCs from 2005-2008 61

Figure 4: Devolved Revenue by the Provinces from 2004-2008 63

Figure 5: The Public Sector Employment from 1990 to 2006

Figure 6: Typical Hierarchy of Current Decision-Making in a Ministry 123

Figure 7: The Trends of Budget Deficits and Public Debt from 2003-2008 129

Figure 8: The Post-Independence Administrative Structure of SL 247

Figure 9: The Revised Model of Public Management Reform 269

\section{List of Tables}

Table 1: Composition of the SL Government in 2008

Table 2: Degree of Decentralisation 1990-2004 64

Table 3: Budget Outturn for Provincial Council 65

Table 4: Number of Complints Received by the Bribery and Corruption Commission $\begin{array}{ll}\text { from 2000-2007 } & 120\end{array}$

Table 5: Reporting Requirements under the Fiscal Management (Responsibility) Act $\begin{array}{ll}\text { of } 2003 & 128\end{array}$

Table 6: Revenue Figures of IRD, Government Financial Statements and Annual $\begin{array}{ll}\text { Reports of the Central Bank } & 130\end{array}$

Table 7: Capital Budget and its Utilisation 133

Table 8: Gross and Net Privatisation Proceeds as a Percentage of GDP, Selected $\begin{array}{ll}\text { Years } & 179\end{array}$

Table 9: Capital Investment in Selected Privatised companies 180

Table 10: Direct Employment effects of Privatisation for Selected Companies (Average Employment) 


\section{List of Boxes}

Box 1: Grade 1 School Admission for the Year 2008

Box 2: Health Sector Strike 82

Box 3: Teachers' Salary Anomaly 83

Box 4: A Famous Story of Political Victimisation of a Public Officer 170 


\section{Chapter 1: Introduction}

\subsection{Background and Interest}

After obtaining the Master's degree in Development Administration from the Australian National University (2000), my determination and curiosity in learning public policy and day-to-day aspects of public administration in Sri Lanka (SL) grew more and more over the years. Being a career bureaucrat attached to the Sri Lanka Administrative Service (SLAS) I was very keen to find out how public administration and public policies contribute to the daily life of Sri Lankans. The media very often criticises the public service as inefficient. With each passing year criticisms of the public service grow. Both the United National Party (UNP) and the Sri Lanka Freedom Party (SLFP), which have alternated in power since Independence (1948), when in power and/or in Opposition have always voiced their intentions to reform the public service; and they have established various reform committees and altered the Constitution but nothing has happened. What has in fact really happened is that the public service has been politicised and made not only more inefficient but also corrupt. Furthermore, the World Bank and Central Bank of SL (CBSL) continuously highlight in their reports that the Sri Lankan Public Service (SLPS) has been overstaffed. According to the 2009 annual report of CBSL, the public service cadre accounts for over 1.2 million to serve the population of 20.4 million (mid-year population in 2009). The excess of $\operatorname{staff}^{2}$ in the public service is in fact wastage of 'the workforce'. The wastage of 'the workforce' is wastage of money. Furthermore, it badly affects the private sector development because there is a shortage of educated manpower for private sector employment (World Bank, 2004). These criticisms and ideas encouraged me to explore the following puzzle in this research.

\footnotetext{
${ }^{2}$ SL's per capita employment in the public sector is the largest in South and East Asia: 57 per 1000 population (India -19, Pakistan - 19, Nepal - 37, Bangladesh - 10, Indonesia - 21, Singapore 0- 23, Philippines -23) (World Bank, 2004).
} 


\subsection{Research Puzzle}

SL follows an executive President style of government but with Cabinet members chosen from Parliament. A system of provincial councils and village level local bodies provide the base. SL recognises the value of investing in human resources and promoting gender equity. As a result, SL has achieved human development outcomes more consistent with those of high income countries; the literacy rate is $91.3 \%$ and life expectancy is 74 years despite its low income level (Central Bank, 2009). It also liberalised its economy in the late 1970s, ahead of other developing nations. SL is the most open economy in the South-Asia region (Sarvananthan, 2005; World Bank, 2000). Despite the civil conflict over two decades, the annual growth rate of GDP has generally been maintained at $4-5 \%$. Its per capita income at market prices (US\$ 2014) in 2008 remains the highest in the region after the Maldives (Central Bank, 2009). However, there is a growing realisation that SL's development has been well below its potential. In the 1960s SL had the same per capita income as Korea, Malaysia and Singapore (World Bank, 2000). Today these countries have per capita incomes that are several times higher than SL's.

Several attempts have been made at reforming the SLPS in recent decades particularly in the 1980s and 1990s. For example, the government introduced privatisation of public enterprises in early 1980s. By mid 1994, 43 industrial enterprises and 92 bus depots had been privatised (Salih, 2000). By 1997, the number increased, which included several plantation companies, and mega utilities such as telecommunications and gas. By December, 2004, in addition to 92 bus depots, approximately 98 public enterprises had undergone privatisation (Public Enterprises Reforms Commission, 2004). The total sale proceeds amounted to SLRs. 69,008 million. It was pushed to the top of the government policy agenda as a part of the Structural Adjustment Reform Programme (SAP) of the International Monetary Fund and the World Bank. The SAP programme also introduced several other measures: tariff and industrial policy reforms, liberalisation of trade and payments, rationalisation of public expenditure, de-control of prices and interest rates, promotion of the private sector, foreign investment promotion, and financial sector reforms, civil service rationalisation and enhancement of public sector efficiency (Adam, Cavendish, \& Mistry, 1992). 
In addition, in the 1990s the government invited two missions, UNDP and ADB, to improve public sector management. These missions consisted totally of foreign experts. The UNDP mission submitted a report within three months and formulated a project at the cost of US\$ 1.3 million (Nadarajah, 1997) and established a Restructuring Management Unit in the Ministry of Policy Planning and Implementation which continued for three years (Wanasinghe, 1994). The ADB Team consisted of consultants from the USA and New Zealand, and focused on the reorganisation of public administration structures, rationalisation of public sector cadres, introduction of results-based management systems and procedures, training of staff and separation of policy-making, service delivery, and regulatory functions of government (Root, Hodgson, \& Vaughan-Jones, 2001).

Further, in 1996 the government introduced an individual performance appraisal system for government. The main reason for the evolution of the performance appraisal system in the government was to rationalise the important decisions on individual employees such as promotion, training, and granting of salary increments, which were hitherto based on subjective judgements. Another reason was to give individual employees a sense of direction.

In addition, in 2003 the government implemented a Fiscal Management Reform Programme in order to respond to the fiscal challenges. This was intended to improve the effectiveness of tax administration, the budget framework, public expenditure management and control systems, and to strengthen fiscal discipline (ADB, 2004a, p. 11).

Despite these reform attempts major problems still remain. The first major problem in the SLPS is lack of delegation of authority (Root, et al. 2001, ADB 2004b). The $13^{\text {th }}$ Amendment (1987) to the Constitution of 1978 led to the establishment of Provincial Councils as a means of devolution of power to sub-national levels to meet the aspirations of the Tamil community. Even today adequate autonomy in the area of financial and human resources decisions have not been granted to these councils. Central government retains ultimate control (Leitan, 1992; World Bank, 2006). 
The second major problem in the SLPS is that there are a large number of public enterprises and ministries. The current number of operational public enterprises is 221 of which 90\% are persistent loss makers (Department of Public Enterprises, 2004; Public Enterprises Reform Commission, 2004). Around 2\% of the GDP is spent annually for their survival (Knight-John \& Athukorala, 2005). In an interview the Chair of the Administrative Reform Committee (ARC) of 1986/89, S. Wanasinghe said "every government that comes into power creates new ministries without any rationale in order to satisfy the ruling party politicians and changes are made to the administrative set-up" (Interview, 9.11.2007). As at 2007 there were 56 Cabinet Ministers and 35 non-Cabinet Ministers and 20 Deputy Ministers in the central government (Government of Sri Lanka, 2007a). In addition, there were 40 Ministers in the Provincial Government (Appendix 1). As a result, a large number of government ministries consume a considerable amount of taxpayers' money burdening the government budget and wasting financial, human and other scarce resources (see 4.3.1 for details). Further, the creation of large number of ministerial positions, gives undue privileges to politicians and their personal staff ${ }^{3}$ at public expense when the vast majority of people in the country are struggling to meet their basic needs. More than $15 \%$ of the population in SL is still under the poverty line (Department of Census and Statistics, 2006/7). In addition, this situation paves the way for misuse of public resources, duplication of functions, cronyism and nepotism.

The third major problem in the public sector is corruption (Auditor General, 2006; Committee on Public Accounts, 2007; Committee on Public Enterprises, 2007). Certain government departments responsible for the issuance of licences, permits, deeds, revenue collection, and law enforcement are very corrupt (see 4.4.2 for details). A Bribery and Corruption Commission was established in 1994 to investigate allegations of bribery and corruption; to date the Commission has failed to investigate and bring about the successful prosecution of even a single significant case. Furthermore, the public sector suffers from political interference in the government decision-making process (Root et al., 2001). In 1999, the Human Development Centre ranked SL very low at $47^{\text {th }}$ in a group of 58 countries in

\footnotetext{
${ }^{3}$ A minister's personal staff consists of a private secretary, two coordinating secretaries, public relation officer, media secretary, personal assistant, security staff and drivers. In addition, there are many consultants.
} 
economic governance, particularly due to increased politicisation, a bloated bureaucracy, insufficient decentralisation and weak financial control and public accountability. In 2007, the Human Development Index ranked SL at $102^{\text {nd }}$ among 182 countries (Central Bank, 2009). In 2009, the Transparency International, the global coalition against corruption, ranked SL at $97(3.1 \mathrm{CPI})^{4}$ in a group of 180 countries (Corruption Perception Index, 2009).

The fourth major problem in the SLPS is overstaffing (Root et al., 2001). SL's per capita employment in the public sector is the largest in South and East Asia: 57 per 1000 population (see Footnote 2 above). Despite the existing overstaffing, in 2001, twelve thousand graduates were recruited to the public service. From 2005-2007 over hundred thousand including fifty thousand unemployed graduates were recruited to the public sector (Ministry of Finance and Planning, 2007, p.85). By the end of 2008, the total number of government employees was around 950,000 excluding semigovernment sectors, standing at around $13 \%$ of the labour force of the country (Ministry of Finance and Planning, 2008, p.67).

The implicit conclusion is that the governments of the past have not effectively tackled the problems. Therefore these problems persist despite many attempts at reform over the last 30 years including one major systematic and far-reaching review. With great enthusiasm, an ARC was constituted in 1986, under the directive of the President, as an integral part of the 1980s economic reforms (Wanasinghe, 1994). The committee was composed entirely of Sri Lankans with outstanding public administration expertise (Nadarajah, 1997). The committee viewed administrative reform as the reform of a system, not merely the addressing of an individual problem or limited group of problems within such a system. For example, it was not limited to a salary review or a cadre review, or an examination of work systems and procedures of government departments. It was a comprehensive review and evaluation of the public administrative system as a whole. Its recommendations would have led to an effective and independent public service. However, no serious attempt has been taken to implement its recommendations as a whole (Wijesinghe, 1998). Nevertheless, the ARC's assumptions and recommendations are still valid and

\footnotetext{
${ }^{4}$ Corruption Perception Index scored below 5 on a scale from 0 (perceived to be highly corrupt) to 10 (perceived to be low level of corruptions).
} 
critical in the SL administrative reform context. This will be dealt with in detail in Chapter 6.

The changes that have been made so far were isolated, ad hoc, and reactive to crisis situations rather than proactive. On many occasions such changes were often made without an adequate examination of their effects on the system as a whole. This resulted in more problems or even greater complexity. As such, solutions to the above problems are obviously not simple; otherwise improvements would have already occurred. So the answer has to lie deeper in the historical, structural, political and cultural underpinnings of the society that shape the institutions and functioning of SL's government (the executive and the legislature) and the public sector.

In short my key research puzzle is: SL did well in the past during the 1960s. Several serious attempts have already been made at reforming aspects of the SLPS in recent decades particularly in the 1980s and 1990s, yet major problems remain. There seems to be few prospects for their elimination, much less for major improvement. Why is this so? What explains this situation?

\subsection{Research Objectives}

The objectives of this research are as follows.

To understand the complexity and specificity of the current situation of the public administration in SL;

To analyse the past in order to derive historical, sociological and politicaleconomic explanations of the present, with special reference to the recommendations of the $\mathrm{ARC}$;

To understand the major drivers for historical administrative reforms and resistance to reforms;

To understand how ideas about reform developed and were chosen for implementation; 
To identify the causes of their successes and failures and consequences of these to explore what are the prospects for today and tomorrow.

The objectives above are pursued by focusing on the following main areas and investigating a number of questions.

\subsection{Main Focus and Research Questions}

This thesis is built on the assumption that a system of government reflects the specifics of the country out of which that system emerged and that any attempt at 'reform' must be built on those specifics. In the course of my literature review, I found that the ARC was based on the same assumptions. The ARC, therefore, provides a useful point of entry for this thesis. An understanding of how and why the ARC took the approach it did and how and why its major recommendations were not implemented provide important clues regarding the larger question this thesis explores. Therefore, this thesis pays considerable attention to the ARC as a way of giving direction and focus. Accordingly, my main research questions are:

Why are there still so many problems in the SL public administration despite various approaches to reform? Why and how have key historical, structural, sociological economic and political factors since Independence contributed to the current situation? Depending on that explanation, what prospects for reforms in SL exist now and in the immediate future?

Why did the government establish the ARC? How did ARC construct the problem which it recommended for fixing? How and why did it derive its recommendations? Why have the ARC recommendations not been fully implemented?

\subsubsection{Subsidiary Questions}

The study, and especially the data gathering process, is guided by the following questions:

What major public sector reforms have been introduced in SL since $1956 ?$ 
What have been the primary causes of reforms? What have been their impacts?

Were these really the most important things that should have been reformed?

Are there others more important? If so, why are they more important?

Which groups in Sri Lankan society stand to gain or lose through public administrative reform?

In what way are public administrative and constitutional reforms linked in SL?

How was the civil service during its early history, and after 1970s? Why did it develop in that shape?

Can public sector reform be independent from governmental reform?

What kinds of reforms can be considered in SL in the light of present and past experience?

The prospects for improving SL's public administration provide the final focal point in this study. Although many attempts to reform aspects of public administration have been made, there is still plenty of room for significant improvement in administrative structure, systems and processes in terms of efficient service delivery and effective localised services.

It should be noted that this analysis covers the period from the 1950 s to the recent past, stopping at 2005. Since my interest was the historical context of previous attempts at reform, especially the ARC, choosing 2005 allowed me enough time for review any initiatives in the 1990s and 2000s that followed the wide-ranging ARC agenda. But that does not mean that work on public sector reform in SL has stopped since then. The current initiatives started after 2005 have not had sufficient time to 
mature, so that they are not yet ready for a proper analysis. It is certainly true that some significant events have occurred recently (e.g. the military defeat of the LTTE on May 2009), but these are not the main concern of this thesis. Notwithstanding, I comment on these in the post-script.

\subsection{Chapter Outline}

The rest of this thesis is organised into six chapters. The conceptual framework and the methodology of this research are developed in Chapter 2.

Chapter 3 provides background on the SL administrative system. It introduces the current structure and process of government in SL. It examines the power invested in the three arms of the government machinery: the Executive, Legislature and Judiciary and their operation in relation to public administration. It also discusses the provincial government and gives a brief account of the composition of the public service.

The current situation of the public administration is explored in Chapter 4 with a view to provide a backdrop to the agenda that lies ahead and highlights issues in the present system that need to be addressed as a part of that agenda. Chapter 4 has three parts:

Part 1 focuses on the roles and scope of public administration under devolved

polity and market economy, and highlights the structural and service delivery deficiencies in the current administrative setup;

Part 11 critically discusses staffing matters in public administration; and

Part 111 focuses on major critical factors in public administration such as discipline, corruption, trade unionism, deficiencies in systems, procedures and financial management functions. 
The focus of the analysis is to understand the complexity and specificity of the present situation in order to finally assess the prospects for reforms in the future.

Chapter 5 also has three parts. Part I describes the post independence administrative reform initiatives during the 1950s and 1960s while part II and III deal with the 1970s-1980s and 1990s-2000s respectively.

The ARC reports of 1986/88 which are central to this thesis are reviewed in Chapter 6 while examining why the recommendations of the ARC have not been fully implemented by successive governments. This analysis will provide a basic foundation for this thesis and show the specifics of the SL situation.

Chapter 7, the final chapter, analyses the overall research findings, evaluates the applicability of theoretical model used in this thesis, revises the theoretical model based on SL's reform experiences, highlights key issues to be addressed in future reforms, draws some conclusions, and highlights major policy challenges for future reforms in respect of public service, including the political system.

Chapter 8, the Post-script Chapter, tries to update the reader on public sector reforms since 2005 because this thesis has been focused only on public sector reforms from 1950-2005. There were two events in particular that had a potential impact on the matters raised in this thesis. The first of these events was the election of President Mahinda Rajapaksa in 2005 and the subsequent work on the "Mahinda Chintana" (Mahinda's Vision) ${ }^{5}$ and the second, the military defeat of the Tamil Tigers in May 2009. This Post-script chapter discusses whether either of these enable the government to address the particular issues of public administration and government identified in this thesis?

The thesis argues that public sector reform, per se, has no universal framework. What can be done in any jurisdiction is a product of its history, structure, culture and the polity of the country. Therefore, one cannot contemplate future reforms in SL's

\footnotetext{
5 'Mahinda Chintana' is the Presidential election manifesto submitted by the present President, Mahinda Rajapaksa in 2005.
} 
public sector unless one understands the full complexity and specificity of what has happened in the recent past. The 'specificity' is the central part of this thesis. 


\section{Chapter 2: Conceptual Framework and Methodology}

[E]xcluding useful [memories and histories] because they carry an undesirable residue from the past renders public administration dialogue weaker and less effective in dealing with current problems for the future.

(Quoted in Raadschelders, 2009, p. 1)

\subsection{Introduction}

As will be seen in following chapters, SL has already attempted several reforms of its civil service and public administration, some of them being 'new public management' in character. But, in general, these reforms have been only partially successful. This thesis attempts to understand why and what these conclusions say about future prospects. One set of reforms flowing out of the work in the late 1980s of the Administrative Reform Committee (ARC) were holistic in character and, in theory, could and should have worked and so the reasons for failure are a particular focus in this thesis. Despite all these efforts, there is plenty of room in the SL's public administration and management for improvement.

Sections 1.4 and 1.4.1 in Chapter 1 indicate the key questions that this thesis tries to answer. Those questions demand historical answers. Thus, the question that arises at this stage is which perspective to adopt in understanding why particular approaches to reform were adopted at certain times, why so little progress has been made and what to do about it?

In general terms, two possible approaches are (1) a normative approach based moreor-less on mainstream public management and/or rational choice theory; and (2) an historical and institutional approach. 


\subsection{Historical vs. Rational Choice Approaches, and a Rationale for Adopting the Former}

Most public management analysis is analysis of the present, for the future, and the analysis is generally prescriptive - a paper examined later from Bale and Dale (1998) is a good example (others are ADB, 2004; Boston et al., 1996; and the World Bank, 2000, 2004).

However, there is another school of thought which argues that there is a need to understand the past in order to effectively address the present problems (e.g. Pollitt \& Bouckaert, 2000, 2004; Raadschelders, 2009, Thelen, 1999). These writers argue that to improve the understanding of government's role and position in society, public administration scholarship needs to reacquaint itself with the nature of time. For example, Raadschelders (2009, p. 1) argues:

Most publications are focused on current problems (the present) and desired solutions (the future) and are concerned mainly with organizational structure (a substance issue) and outputs targets. There is much less consideration of how public administration (organisation, policy) unfolds overtime and how the present both limits the range of possibilities available for the future and yet provides certain possibilities for action. History and administrative history is regarded as a 'past' that can be recorded for its own sake but has little relevance to contemporary challenges".

According to Raadschelders (2009), there is a lack in probing the meaning of the past. He is critical that "many people are not particularly interested in how the past has shaped the present" (Raadschelders, 2009, p.1). He further emphasizes that discarding the past as mere baggage runs the risk of throwing the baby (present and future) out with the bathwater (past). Illustrating the point, Beyer (1959) notes that better understanding of current personnel practices requires a longer historical perspective than is normally displayed in studies in this field (Raadschelders, 2009).

According to Raadschelders (2009), history is the memory of a collective past through learning about previous achievements. Analysing administrative changes in SL over time is essential to understanding why the present is the way it is. We cannot 
fully understand our present without understanding our past. And we cannot fully imagine change in the public service without a sense of how our public services change over time. Our ability to understand the past gives a solid background to the existing problems in the public service. It provides a wide range of explanations and the sociological, cultural, historical, political, and economic factors that led to present impasse and their complex interaction, which have shaped the system of government over time. One could say that, public administration scholarship lingered between "exploring the past for understanding the present" and "analysing the present in order to create a better future" (Raadschelders, 2009, p. 3).A persistence and thoughtful study of a past provides potential clues, not definitive answers, to understanding, not explaining, present challenges and potential solutions to present problems. Studying administrative history helps understanding of government and the limitations within which any practitioner has to work (Raadschelders, 2009).

Raadschelders (2009, p. 10) identifies three reasons why understanding the administrative past is important to anyone. First is that government is a product and function of human action and a consequence of natural forces, thus human behaviour is purposive, focuses on progress and dealing with the challenges of daily life. The outcome of that behaviour can only be understood when that what motivated particular action is placed in its temporal and geographical context. Second is that many aspects of social reality are best comprehended as a temporal process. The impact of what is started now often doesn't come clear until a significant amount of time has passed. Social realities unfold over time and without a historical perspective the why and meaning of this unfolding is lost. This is problematic for political officeholders because they focus on short term solutions to problems due to short electoral cycle, pressure from interest groups, and desire to show results. However, many of the national and international challenges play out in the longer term. To balance this pressure for quick result with long-term perspectives is the biggest challenge faced by the administrators. Considering the past will facilitate such a balancing act. Third is that national cultures are shaped by political and administrative traditions. Many cultures are still shaped by the traditions of various institutions of governance such as government, corporate business, organised religion, tribe or clan. These institutions are underpinned by deeply embedded ways 
of acting that are regarded as 'normal' in those cultures and which influence what, how and why people act in the present.

In contrast, rational choice theory is another approach used by social scientists to understand human behaviour. This approach has been dominant in economics, but in recent decades it has become widely used in other fields such as sociology, political science, and anthropology. Rational choice perspectives all begin with individual behaviour located in a perpetual present (Marsh \& Stoker, 1995, Scott, 2000). The central theme of the public choice perspectives is that individual behaviour in an organisation is based on rational calculation of self interest. Rational choice theory assumes that all actions is fundamentally 'rational' in character and that people calculate the likely costs and benefits of any action before deciding what to do. It further assumes that the society tries to achieve equilibrium. Furthermore, the public choice theory embraces a functional view of institutions (Thelen, 1999).

Rational choice theory adopts a methodological individualist position and attempts to explain all social phenomena in terms of the rational calculations made by selfinterested individuals. It sees social interaction as social exchange modelled on economic action. People are motivated by the rewards and costs of actions and by the profits that they can make. Some rational choice theorists have seen rationality as a result of psychological conditioning. Others have adopted the position that it is simply necessary to assume that individuals act as if they were completely rational (Scott, 2000). However, collective actions in society and organisations make this assumption problematic. Accordingly the problem of collective action poses considerable difficulties for rational choice theory, which cannot explain why individuals join many kinds of groups and associations. In addition, rational choice theory cannot explain the origins of social norms, especially those of altruism, reciprocity, and trust. Furthermore, rational choice theory is deductive; it tends to start from general theory and work downwards, descriptively and prescriptively, to particular cases.

In contrast, the historical institutional approach which is one of the central pillars of the discipline of politics focuses on structures, rules, procedures and formal organisations of government. It adopts the techniques of the historian and seeks to 
explain the relationship between structure and democracy and the ways in which rules and procedures of formal organisation succeed or fail in constraining political behaviour (Rhodes, 1995). Homans argued that "human behaviour, like all animal behaviour, is not free but determined. It is shaped by the rewards and punishments that are encountered" (Scott, 2000, p.2). This means that peoples' behaviour is not always based on rational choice but it is governed by institutional standards. Therefore, Durkheim (1983) argued that all rational economic actions occur within an institutional framework of norms that cannot itself be explained as the result of rational action alone (Scott, 2000).

Accordingly, adopting historical institutionalism in order to find sequences of social, political, economic behaviour and change across time is very useful in understanding the current situation in public administration in SL. Even though historical institutionalism provides a comparative approach to the study of all aspects of human organisations, it is also applicable in analysing the history of public management reforms in a single country like SL. According to Thelen (1999), the historical institutionalist starts from evidence (empirical work) unlike rational choice theorist who starts from theory. It means that the historical institutionalists begin with empirical puzzles that emerge from observed events. This is the approach adopted in this research.

For these reasons, this study adopts an historical institutionalist position in analysing public administration reform in SL.

\subsection{Generic Prescription and Policy Transfer Approaches}

This thesis seeks to describe and explain public sector reforms in Sri Lanka but it also identifies critical present-day issues in order to understand the prospects for ongoing reform. As also seen, an historical and institutionalist approach looks for the origins of the present in the past and argues that the way forward must focus on the specifics of the situation. 
This is in contrast with mainstream approaches to public administration that adopt a generic and prescriptive approach to ongoing reform, in effect, arguing that even developing countries can and should define their problems in standard terms and apply a more-or-less generic 'new public management' model as the solution. An example of this type of approach can be found in Bale and Dale (1998). They take the view that:

Poorer countries can indeed extrapolate from the experience of their higher income neighbour despite the different conditions under which they have to operate. New Zealand's comprehensive overhaul of its public sector affords both general principles and specific elements relevant to countries looking to improve the quality, efficiency, and cost effectiveness of their public service sectors, and a careful analysis of those reforms can ascertain what might be transferable and what principles might apply (Bale \& Dale, 1998, p. 103)

Bale and Dale in the first instance claim that any developing country can adopt a developed country model despite the different cultural, political or socio-economic conditions. An historical institutionalist approach would reject this view. But it is also noteworthy that even a well-known admirer of the New Zealand system does the same.

Schick (1998) in his World Bank paper on 'Why developing countries should not adopt the New Zealand model" disagrees with the Bale and Dale type of approach and does so in terms that support the intent of this thesis. He argues that NZ does not offer practical guidance on how developing countries should surmount deficiency in public management. NZ has implemented a large number and range of reforms since 1998. This includes accrual-based accounting and appropriations, budgeting for outputs rather than for inputs, decoupling service-delivery functions from the provision of policy advice, replacing department heads with chief executives appointed for a fixed term, discretion for managers to spend their operating budgets as they deem fit, individual employment contracts for most senior (and many middle) managers, a charge on the use of capital by government departments, annual purchase agreements between ministers and their departments, annual reports, and audited financial and performance statements (Schick, 1998, p. 2). 
Each of these innovations are specific and can be considered on their own (Schick, 1998). Further, every element of reform has been designed to establish or strengthen contract-like relationships between the government and ministers as purchasers of goods and services, and departments and other entities as suppliers. A chief executive negotiates with employment contract with managers while promising results in negotiating purchase agreements with ministers and performance agreements with the State Services Commissioner. Contract-like agreements have been extended to policy advice by the ministers who opt to obtain information and ideas from external sources. Before the start of the year the outputs are specified in purchase agreements signed by the chief executive and the minister purchasing the services and after the year each department publish annual report that specifies the outputs actually produced, so that the government can determine whether the terms of various contracts have been fulfilled.

Schick is of the view that "there are important preconditions for successfully implementing the new public management (NPM) approach; these should not be ignored by countries striving to uplift themselves after decades of mismanagement" (1998, p. 124) - clearly, SL is an example of this. He argues that greater the shortcomings in a country's established management practices, the less suitable these reforms are. He particularly points out the danger of application of the 'NZ Model' which gives public managers broad discretion to operate within an accountability framework that specifies the results to be achieved and closely monitors performance. According to Schick (1998, p.5), formal contracts and internal markets were feasible for NZ because the country already was developed - it had a robust market sector and established mechanisms for enforcing contracts. He points out that if contracts and the rule of law are underdeveloped in business relations, it is highly improbable that they can be effectively applied in the conduct of the government business. Schick further emphasises that developing countries with weak rule-based governments and market structures that are less robust should consider improvements before experimenting. Therefore, developing countries should consider their established structural and management settings first, before application of any foreign model. In other words, Schick seems to be arguing that something like 
an historical and institutional perspective is more appropriate in looking at any particular country and its attempts at reform.

The approach adopted in this thesis also contrasts with another well-known approach in explaining the origins of public sector reform in developing countries, namely the 'policy transfer' approach. From this perspective, the fact that some reforms in Sri Lanka in recent times have reflected aspects of the 'new public management' agenda, could be explained by the fact that international agencies in their relationships with Sri Lanka, have created the conditions for a 'transfer' of ideas about public sector reform to that country. Authors such as Dolowitz and Marsh (1998) define 'policy transfer' as 'the process by which knowledge of ideas, institutions, policies and programmes in one time and/or place is fed into the policy making arena in the development of policies and programmes in another time and/or place" (Dolowitz \& Marsh, 1998, p. 38). For example, Shamsul Haque (1996, pp. 206-7) argues that the international agencies such as the World Bank, the US Agency for international Development, and the British Overseas Development Administration have influenced Third World countries to adopt pro-market policies; and John Campbell (1977) demonstrated how the institutional legacies of Poland, Hungary and Czechoslovakia helped account for different national outcomes when IMF attempted to impose neoliberal policies on these countries as a condition for a loan guarantee (Dolowitz \& Marsh, 1998, p. 38).

Dolowitz and Marsh (1998, p. 38) ask the following questions: "Why and when do actors engage in policy transfer? Who transfers policy? What is transferred? From where are lessons drawn? Are there different degrees of transfer? When do actors engage in policy transfer and how does this affect the process? and What restricts policy transfer?"

In this framework, Dolowitz and Marsh emphasises the need to consider policy transfers between national, sub-national and international (cross country) units. They also consider the need for examination of the global past, more importantly research on their own nation's past because this type of search save time and resources both political and economic associated with cross-national policy transfers. These are the types of questions that might be asked in this thesis. 
However, this framework has a limited focus, only on public policy transfer. It does not cover other broad questions which are critical in analysing management change. This thesis raises several critical questions which need answers to analyse the history of public administration reform in SL such as what are the drivers for historical administrative reform, how ideas about reform developed, what are the causes or successes and failures and consequences of reform and who won and loss due to reform. This drawback led to a search for a more comprehensive theoretical framework for this study.

Instead, the conceptual and analytical framework developed for this study is one that is historical and institutionalist in character and which begins from the idea that empirical analysis of the actual history and dynamics of SL's political and administrative system is critical to understanding the present. One comparative model that is also based on these preferences can be found in the work of Pollitt and Bouckaert (2004) and the next section summarises this framework.

\subsection{Historical Institutionalism: Pollitt and Bouckaert}

Pollitt and Bouckaert argue that in the field of public management reform the broader forces of economics and politics are always mediated through networks of institutions. "The specific characteristics of these networks, and of the individual institutions which compose them, frequently have a profound shaping effect upon what actually happens during the course of reform, therefore, upon the final results and outcomes of the change process" (Pollitt \& Bouckaert, 2004, p.23).

The basic assumption of this model is that the pattern of management change and the causes of influence differ from country to country because the effects of global and domestic forces are not uniform (Pollitt \& Bouckaert, 2000, 2004). Accordingly, the socio-economic forces, political systems and administrative systems of the individual country are specific in the determination of the change agenda of a particular country. From this model the authors develop more detailed sets of typologies and specific theories that classify and explain specific patterns and trends, both within individual countries and across group of countries. This model is originally created 
through country specific experiences. Therefore, it represents a combination of the reform experiences of 12 developed countries (Pollitt \& Bouckaert, 2000, p. 4). Figure 1 reproduces their diagrammatic representation of the model.

Figure 1: Pollitt and Bouckaert Conceptual Model

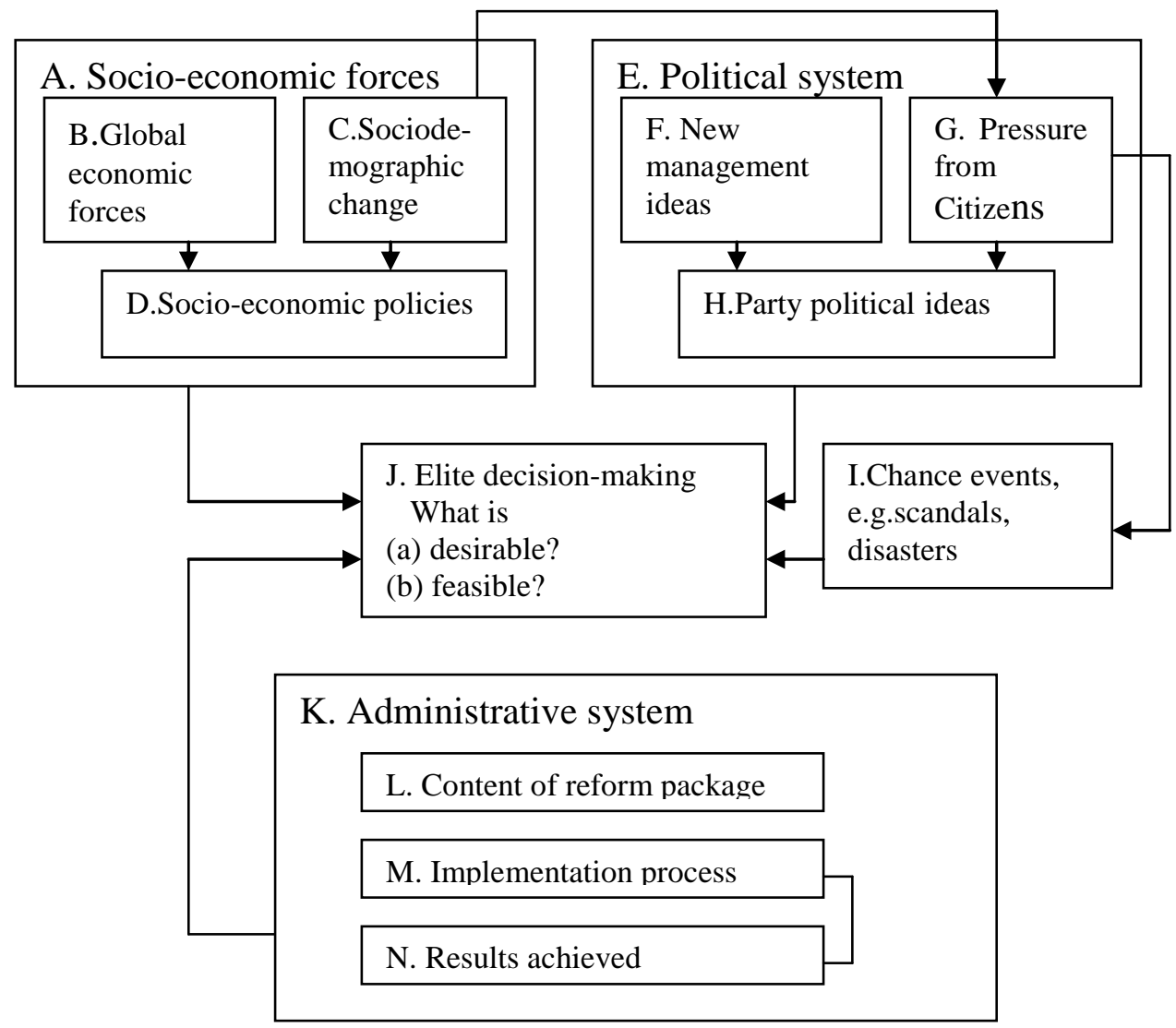

Source: Pollitt and Bouckaert (2004, p. 25)

Figure 1 indicates the broad forces which are driving and resisting changes. It stresses that most of the changes in the public sector originate from the top, particularly executive politicians and/or senior civil servants. This is illustrated in the middle of this model (Box J). Therefore, it is the first place to start in understanding any reform. For example, the 1980s reform in NZ was driven by) a small group of ministers who advocated neo-liberal economic solutions and Treasury officials who thought along similar lines (Boston 1991). In Box J, elite perception is differentiated between elite discernment of what reforms are desirable and what reforms are feasible. What is desirable is not always easy to achieve due to various environmental factors. Elites therefore have to make judgements on what is feasible as opposed to what is desirable to avoid any resistance and make change happen 
according to the current political, socio-economic, and cultural milieu. Otherwise, elites in decision-making in the centre (Box $\mathrm{J}$ ) are influenced by two large elements in the reform: socio-economic forces and political system (components of Boxes A and $\mathrm{E})$.

In this model, surrounding elite decision-making are three clusters of factors. In the top left the first cluster is socio-economic and demographic elements: Box A (Boxes $\mathrm{B}, \mathrm{C}$ and $\mathrm{D})$. In the top right the second cluster is political and scholarly elements: Box E (Boxes F, G, and H). In the bottom part, the third cluster is administrative elements: Box K (Boxes L, M and N). The management reforms emerge from the interaction between these three major elements.

Box A illustrates the general set of factors. Some of these can be considered to be structural and long-lasting while other factors may be short-lived, such as economic cycles of upturns and downturns. The elements in B, C and D are likely to have definite and apparent effects on public administration. Socio-economic policies (Box D) are derived from global-economic forces (Box B) and socio-demographic changes (Box C). Based on the experiences of 12 selected countries, Pollitt and Bouckaert argue that the most influential factor in reform is the global economic forces. The global capital markets and multinational corporations control the individual governments, thus 12 developed countries that the model is based on cannot entirely design their domestic policies their own way.

In this model the second group of influential factors is concerned with the political system (Box E). These elements may make management reform more or less straightforward. For example in Germany constitutional laws make it difficult for robust restructuring to take place at the federal level, whereas in the UK changing the structure is less difficult (Pollitt and Bouckaert, 2004). Thus, the political system and laws affect the process of management reforms. New management ideas (Box F) also heavily influence management reform. Over the last two decades a variety of schools of thought emerged in the area of the new public management. According to Bovaird \& Loffler (2003, p. 42), this approach has many names such as "New Public Management" (Hood,1991), "Market-Based Public Administration" (Lan and Rosenbloom,1992), “Managerialism” (Pollitt,1990),“Reinventing Government" 
(Osborne and Gaebler, 1992) and "Post-Bureaucratic" model (Barzelay,1992), and has been adopted across countries based on economic rationalism and private sector management practices (Hughes, 1994). Thus, the US re-invention process, the Canadian "La Rele've", the UK "Next Steps", the NZ and Australian versions of "Contractualisation", the Irish "Strategic Management Initiatives", the German "Lean State" reform programme and the Scandinavian reforms, despite significant differences, were all seen as part of the new public management phenomenon. Overall, these reforms sought to achieve smaller and better government with less cost. These ideas are significant for the pace of public management reform. For example:

in Australia, North America, and the UK generic approaches and techniques such as Management by Objectives, TQM, benchmarking, outsourcing, and business process re-engineering have been widely adopted in the public sector" (Pollitt \& Bouckaert, 2004, p. 30).

Along with these ideas, organisational design principles based on macro economic theories have also been used; for example, in $\mathrm{NZ}$ public choice theory ${ }^{6}$, agency theory $^{7}$ and transaction cost theory ${ }^{8}$ were all influential (Boston, 1991). These new concepts were popularised too by international agencies such as the World Bank and the OECD (particularly its Public Management (PUMA) division) through international networks.

\footnotetext{
${ }^{6}$ Public choice theory seeks to explain how voters, politicians, bureaucrats, and lobbyists will behave in different institutional settings with different incentive rules. It is based on the idea that human behaviour is dominated by self-interest. For example, bureaucrats attempt to enlarge their departmental budget. Politicians pursue their own objectives at the expense of many of their constituents (Bale \& Dale, 1998, p.118).

${ }^{7}$ Agency theory is based on the idea that interchange between parties can be characterised as a series of contracts where one party, the principal, enters into agreements with another party, the agent, who agrees to perform tasks on behalf of the principal in return for compensation. This theory also assumes rational, utility-maximising behaviour by individuals hence, conflict will arise between principals and agents as their self-interest differ. The theory is useful to analysing the selection of agents, designing incentives and pay systems, and choosing between in-house or outside contractors (Bale \& Dale, 1998, p.118).

${ }^{8}$ Transaction cost theory provides an important adjunct to agency theory and another set of tools and insights for exploring not merely the operation of firms, but also nature, structure, and activities of bureaucracies. It is useful for evaluating the efficiency of alternative governance structures or institutional arrangements (e.g. considering when it is more efficient for the government to provide services directly rather than contracting them out to private sector providers) (Boston et al., 1991).
} 
Box $\mathrm{G}$ represents pressure from citizens. However, this factor is not always powerful and active in the public management reform in those selected countries, but on some occasions citizens do bring pressure to bear for change. Pollitt and Bouckaert (2004) point out that, although citizens seldom seem to be the driving force for particular reform, there can be instances in which they form an important background influence.

Box $\mathrm{H}$ represents party political ideas as another influential factor in the public management reform. Political parties have ideas about how they would like to govern. These include issues of structure, style, and process; for example, a party may decide that it wishes to "reduce the civil service" or "decentralise and bring the administration to the grass root level" (Pollitt and Bouckaert, 2004). Political parties also derive new management ideas (Box F) and ideas from citizens (Box G) which influence the reform agenda.

The other influential factor in this model is chance events (Box I). This includes scandals and disasters (Tsunami, floods and droughts). These factors motivate political and civil service elites to make decisions on changes.

In the bottom part of the framework there is a cluster of administrative factors $(\mathrm{K})$, content of reform package (L), implementation process (M), and results achieved (N). Pollitt and Bouckaert (2004) point out that administrative system (Box K) is often difficult to change in more than incremental ways because the culture and discipline is embodied into the system. Structural differences are also remarkable. Some countries have centralised administrative systems while others have more decentralised systems. Reform from centralisation to decentralisation is somewhat difficult in those countries. Furthermore, rules and regulations are also significant because the civil service cannot change them so readily.

The content of reform package (Box L) is the output of the interaction between the desirable and feasible by the reform elites. Box M illustrates the implementation of the reform: attempt to put reform ideas into practice. This is the important part of the whole reform programme. The implementation of reform through a top down approach involves a number of layers in the decision-making and many levels of 
administration, from Cabinet level to the agency level, so that the chance of effective implementation of the reform programmes depends on the willingness and incentive of the politicians and the senior civil servants' to implement them. The complexity of the implementation process may increase because many of the programmes are delivered through networks of organisations rather than by a single implementer. Another problem in the implementation is that individual reforms may detract from other reforms. Sometimes governments implement reform piecemeal so that it may affect the other structures as a whole.

In addition, implementation itself is crucial in deciding future prospects of reforms by the elite - whether to continue or change track. For example, in New Zealand a sophisticated output-oriented performance management system was put in place from the mid 1980s onwards. By the mid 1990s, NZ recognised the danger of a strict focus on measurable outputs and changed the focus from outputs to outcomes. Box $\mathrm{N}$ in Figure 1 represents the result achieved from the reform. This might, or might not be the anticipated outcome of the 'reformers' due to an uncertainty of the implementation process. Therefore, the final result of the reform is not easy to identify.

To summarise: Pollitt and Bouckaert's conclusion from their 12-jurisdiction study that the outcome of reform initiatives differ from country to country according to the differential impact of a range of key factors, seems to be important, and negates any suggestion that the passage of reform in SL should be assessed against a single generic model such as Bale and Dale's. The Pollitt and Bouckaert model is also persuasive in another respect; unlike the prescriptive approach of much public administration research, it emphasises the importance of observing the presence (or absence) and effect (or otherwise) of a wide range of economic, political, social and cultural factors in a manner that encourages historical analysis over time. As we have seen, parts of Schick's and Dolowitz and Marsh's argument seem to point in the same direction.

Accordingly, this thesis proceeds by adopting the Pollitt and Bouckaert model as a basis for organising the collection and analysis of evidence to examine the 
circumstances prevailing over time and their effects in relation to public sector reform in SL.

The next section explains the research methodology in this study.

\subsection{Methodology}

\subsubsection{Research Approach and Methods of Data Collection}

For the reasons mentioned above, the approach of this thesis is essentially exploratory and so the research design is historical and qualitative (Rhodes, 1995). Given the theoretical exploratory nature of the research in question, predominantly qualitative research is merited (Cresswell, 2003, p. 22). Qualitative research is conducted through an intense and/or prolonged contact with a "field" or life situation, reflective of the everyday life of individuals, groups, societies, and organisations (Miles and Huberman, 1994, p. 6). Also, qualitative research provides theories, models and descriptions of human experiences and perceptions within particular contexts. The researcher's role in a qualitative study is to gain a holistic overview of the context under study, and attempt to capture data on the perceptions of local actors. It is primarily descriptive and interpretative, concentrating on a few selected individuals or phenomena in some detail (Borland, 2001). Denzin and Lincoln (2005, p.4) explain that qualitative researcher use "a wide range of interconnected interpretive practices, hoping always to get a better understanding of the subject matter at hand".

According to Patton (2002) qualitative findings grow out of three types of data collection: direct observation, written documents and in-depth, open-ended interviews. In order to answer the research questions identified earlier in this chapter, several different types of evidence needed to be collected and analysed, particularly documentary and interview evidence. 
Evidence regarding the history of reform in SL required the collection and analysis of a wide range of government documents of the time, supplemented by academic and practitioner research;

Evidence regarding the reasons why certain reforms were initiated, the intentions behind them and the reasons why they succeeded or failed required talking to a selection of individuals who were involved or who observed them at first hand.

Given its exploratory nature, this thesis adopts a "pluralist methodology" which was based on extensive literature review on past reforms and present situation of public administration, primary (qualitative interviewing) and secondary (official and unofficial documents) data collection in SL. My long term work experiences ${ }^{9}$ in the SL public administration gave me a deep understanding of the form and content of these documents and interviews - in that sense I was an 'insider' and able to interpret the material from the same perspectives. To ensure I have not inadvertently brought biases to bear in those interpretations, wherever possible, I checked my key interpretations with my interview subjects in formal and informal discussion (more on this below).

Further, qualitative research was supplemented or supported by quantitative secondary data in this research. Quantitative secondary data was analysed graphically to support qualitative evidence (see Chapter 4).

\subsubsection{Documents}

A review of public administrative reform literature from 1950 to 2005 is the major part of this study. Therefore, this study used several sources of historical data:

Government official and unofficial documents including confidential reports, legislation, country reports, project reports, the Parliamentary Hansard,

\footnotetext{
${ }^{9} \mathrm{I}$, the researcher, was involved in public sector environment from 1984 up-to-date in various capacities as an Assistant Commissioner, a Director and Senior Assistant Secretary. This familiarity allows me to understand what the interviewees were saying and interpret the events.
} 
annual reports, administrative review reports, budget estimates and speeches, circulars and statistical data;

Policies, including Cabinet papers and policy documents;

Public reports including online newspaper articles, and opinions including editorials, speeches, and TV discussions; and

Published research, bilateral and multilateral donor agency documents and books.

Most of this documentary data was collected before the field work. A significant proportion of the research project, the first phase of documentary analysis, involved reading and analysing the materials, constructing a history of reform from 1950 to 2005, and identifying what seemed to be key issues and moments, for example, the conduct of the ARC and the subsequent lack of implementation of its recommendations. This history, particularly the gaps, pointed the way to the key questions to ask the participants and observers to be interviewed in the second phase.

These documents provided me with answers to some research questions particularly relating to official rationales and justifications on post-colonial reform attempts, dates, personnel, and history of implementation and about the public service during its early history and after reforms; major reforms initiatives to administrative system and structure; how reforms ideas developed and were chosen for implementation; and major forces for resistance. However, evidence regarding the reasons why certain reforms were initiated, the intentions behind them; the reasons why they succeeded or failed; which group gained or lost from reforms; and key consequences of reforms were not adequately available in documents, so the gaps had to be filled from other sources. In this regards interviews with a few people who were knowledgeable with the subject were used as a method of data collection. 


\subsubsection{Interviews}

In addition to document analysis, this study gathered data from semi-structured interviews with political elites and senior bureaucrats. The collection of data through interviews was imperative in this study for three reasons. The first reason is that "the nature of management reform is such that an assessment cannot be grounded solely on hard evidence of what succeeded or failed. One's own judgement must be brought to bear, as well as that of others - participants and observers - who have seen the reforms in operation and have thought much about how the system is operating" (Schick, 1996, p.9).

The second reason is that the official documents tell only half the story. The interviews were conducted to fill the gaps and the backgrounds. The historical documents also may be based on official rationalisation or may have been interpreted incorrectly by the writers. Lilleker (2003, p. 207) writes that "interviews provide insight into events about which we know a little, activities that take place out of the public or media gaze, behind closed doors...interviews can provide immense amount of information that could not be gleaned from official documents or contemporary media accounts".

The third reason is that historical research tradition demands procedures to verify the accuracy of statements about the past, to establish relationships, and to determine the direction of cause-and-effect relationships (Marshall \& Rossman, 2006). Therefore, interview data analysis along with the documentary analysis enhances the trustworthiness and credibility of this study.

Mayan (2001) suggests that semi-structured interviewing is useful when knowledge is limited and a topic needs to be explored from the subject perspectives. Aberbach and Rockman (2002, p. 674) state that "elites especially_but other highly educated people as well-do not like being put in the straightjacket of close-ended questions". Therefore, this research used semi-structured interviews to collect data from individual participants through a set of open-ended questions. Appendix 2 shows that there are two questionnaires used in this study (one for the Chair of ARC and the other for the rest of the interviewees). The interviewees were more comfortable in 
answering these questions because they were given a chance to express their opinions freely.

\subsubsection{Interview Sample and Subjects}

The sample for this research had two types of respondents. One sample comprised political elites. The other sample comprised officials, and academics. The views and perceptions of these two sets of individuals are vital, as they provide the impetus for past reforms and their implementation in SL. Accordingly, thirty-five senior politicians, academics and current and past senior public officials were selected for interviews. The sampling for this research was not random. The selection was undertaken, in a careful manner based on following criteria (combined with a small amount of snowball sampling (also called chain sampling), to obtain the deepest and widest range of reform experiences over recent years (particularly in relation to the ARC) (Gray, 2004). It was thought necessary to concentrate on those who:

were involved at the time in decision-making and have subsequently reflected on the changes which took place and observed the reform process;

can cast their memory back, and have a deep interest in the future of SL;

have made an outstanding contribution to research in the area of public sector management and/or;

are currently working in the public sector in the context of being able to render a qualified opinion.

Appendix 3 shows the list of people and their positions in alphabetical order. Interviewees were contacted by letter to seek their agreement and participation in the study. The purpose of the study was explained in the letter. Interview subjects (Chapter 1) were enclosed together with the Informed Consent Form. The letter, schedule of interview subjects and the Informed Consent form had been approved by the Victoria University Human Ethics Committee. Interviewees were informed that the research would not be conducted on a strictly anonymous basis and where appropriate, their comments would be directly attributed to them. The participants 
were also asked to sign the consent form to indicate that they were comfortable with the data collection methods, storage, analysis and the use of the information they gave me in the interviews. They were assured that they were able to withdraw at any time in the research process. The respondents were very generous and forthright in explaining the consequences of past reforms, and also on current situation of public administration and governance in SL.

Of 35 individuals who were contacted 31 agreed to be interviewed but 3 political individuals were not available in the time for the interview. The interviews were spread over four months from early November 2007 to late February 2008.

The interview questions were designed to grasp the respondents' reform experiences from 1950-2005 and the current governance and management practices (2009) and varied according to the individual's experiences of the reforms (Appendix 2). The interviews were in-depth. Several follow-up interviews were held with some respondents. Each individual was interviewed for an average of three-and-a-half hours, a longer interview in one visit or split into two-to-three shorter visits until the entire questionnaire and follow up matters were discussed. The interviews were conducted in English, and where appropriate, Sinhala Language was also used. A translation was done soon after the interviews by me. Every interview was taperecorded and transcribed for analysis purposes.

The interview responses augmented the already available information on past reforms from the documents. The interview responses have been integrated into the related chapters of this thesis to provide insights from those who were actively involved in the reforms as decision makers, implementers or observers. Throughout the text, key respondents have been directly quoted with their consent by their names and positions held at the time of interview as indicated on the consent form. In such cases a copy of the interview transcript was sent to them for corrections and comments. Some of them have made a few corrections. 


\subsubsection{Analysis of Empirical Data}

Empirical analysis is "the process of moving from raw interviews to evidence-based interpretations that are the foundation of published reports" (Rubin and Rubin, 2005, p. 201). The use of multiple sources of information, methods and techniques was sought to validate the data and information using a triangulation process for their reliability (Cresswell, 2003, pp. 195-196).

Interpretation or drawing conclusions of the documents as described by Cresswell (2003) was combined with "explaining the findings, answering the research questions, attaching significance to particular results, and putting patterns into an analytic framework" (Patton, 2002, p. 438). Analysis of the data and information collected through documents, semi-structured open-ended interviews, discussions and direct observations was mainly undertaken manually, through tabulating in tables and graphs and narrating in the most suitable way. The collected official materials and other statistics have been analysed mostly in chronological order; for example, reform initiatives during the 1950s-1960s, introduction of Political Authority in 1971 and abolition of Public Service Commission in 1972, which gave clues to underlying social forces and trends. The historical analysis was further improved with the interview data.

Only the most relevant information from recorded interviews was transcribed verbatim. Each of the transcribed interviews was read through more than once, without coding. For each of the transcripts, the raw data were reduced by highlighting the relevant materials, classification of common ideas into certain themes, discarding, and organising the data into relevant text and transferring to a data reduction sheet. Each relevant text from the transcripts was then coded and summarised into a theme (group of repeating ideas that had something in common). Since my questionnaires focused more on past reforms, case by case, the classification of interview data has been essentially subjective. Wherever possible, I checked and confirmed my interpretations with the subjects but, inevitably, the final analysis in this thesis is subject to whatever framework my professional and academic experiences have given me. In that respect, it may show systematic 
leanings in one direction or another; I will leave the reader to decide whether my interpretations of the evidence are reasonable or contestable.

The primary data findings have been presented in a narrative form while the secondary data were analysed and interpreted mainly by charts and graphs so as to validate the primary data. In the presentation of the primary findings, direct quotes are used to allow the reader to confirm the conclusions. The Pollitt and Bouckaert analytical framework was used in collecting and analysing data in this research.

Finally, qualitative criteria, such as credibility, transferability, dependability and conformability have been used to ensure the trustworthiness of this research. One of the important challenges confronting qualitative researchers is how to assure the quality and trustworthiness of the research. The use of quantitative criteria such as validity and reliability is largely irrelevant to substantiate the findings in the case of qualitative research. It is crucial "to use qualitative evaluation criteria to assess qualitative methods within the qualitative paradigm" (Leininger, 1994, p. 96). Further comments on this follow in the next section.

\subsubsection{Limitations}

There are two particular methodological issues that need to be noted. The first relates to the reading of historical and official documents.

A researcher has to be careful that in reading in the present what were produced in the past, that their contents are interpreted correctly - that the researcher is able to understand their contents in the terms intended. In this case, the documents are all official documents produced in SL since the 1950s. I, the researcher, in this case is Sri Lankan, a speaker of Sinhalese and English and a public servant of many years standing as mentioned above. This gives me the interpretative status of an 'insider' able to read these documents as they would have been intended (Schwartz and Jacobs 1979, Parts I and II; see also Minichiello, Aroni, Timewell and Alexander 1995, Chapter 8) in the SL context. Where possible, to avoid the possibility of researcher bias in interpretation, my interpretations have been checked against the writings of SL public administration academics (as cited in the text) and, in some cases, in 
discussion with them during the field work. In other instances throughout the text, interpretations are offered but with acknowledgement that they are those of the author - so that if biases are apparent, the reader can contextualise them.

Similarly, the adoption of semi-structured interviews as a way of getting the insights of some key participants in the reform processes of the past in SL raises other issues. In this case, to be efficient in data collection, questions were devised that asked the subjects to speak to matters that are absent in the historical record and matters that called on their expert judgement regarding the intentions and outcomes of reforms, particularly those surrounding the ARC. Again, the professional experience of the interviewer enabled me to ask questions that shared the world-view of the interview subjects and to interpret their responses within the meaning-frameworks in which they were intended (Minichiello, Aroni, Timewell and Alexander 1995, Chapters 4 and 5). Moreover, as the analysis proceeded, the subjects were sent drafts of how their responses were interpreted and asked to confirm or correct them. However, it must be acknowledged that while the subjects were generous with their support, time and resources limited the time during which fieldwork could be undertaken. Many topics other than those selected for discussion could not be discussed or were discussed only briefly. If this work is only exploratory, it is to be hoped that others will follow and fill out what has been missed or covered only lightly in this study.

The third methodological limitation of this study lies in the sample of past and present participants in SL's reforms. The interviews were spread over four months from early November 2007 to late February 2008. During this period many bomb explosions occurred in the capital city, Colombo, and suburbs due to intensity of violence by the Tamil militants. One MP was killed on the $1^{\text {st }}$ of January 2008 in a Hindu temple. Another cabinet minister was killed on the way to Parliament. Another minister escaped death for the twelfth time when a female suicide bomber detonated a bomb in the minister's private office while he was consulting his clients (Personal observations). I, the researcher, narrowly escaped from the Slave Island bomb blast while I was travelling to meet one of the respondents. Accordingly there was a political constraint on the participation of others. But I tried hard to select a group most closely involved and those who, by virtue of their experience, would be able to bring a wise and expert view and sharp memory to my questions. However, 
some of the core figures who might have been good to interview were impossible to contribute due to failing memory of the past. 


\section{Chapter 3: Structure and Process of Government}

\subsection{Introduction}

At Independence (1948), SL inherited a centralised administrative structure with two layers: the central government and local government uuntil 1987. This structure was continued, with ad hoc modifications, which will be discussed in Chapter 5 . The $13^{\text {th }}$ Amendment to the Constitution (1987) changed this structure in an attempt at devolving power to the Provinces with a view to addressing the ethnic conflict and building a three-layer structure: the centre, the province, and local level.

This chapter introduces the current structure and the process of government in SL. It examines the power invested in the three arms of the central government machinery: the Executive, Legislature and Judiciary, and their operation in relation to public administration.

\subsection{Current Composition and Structure of Government}

\subsubsection{General Overview}

For administrative purposes SL has been divided into 9 provinces, 25 districts, 312 Divisional Secretariat divisions and 11,818 Grama Niladari (village officer) divisions. Maps of SL indicating provinces and districts are depicted in Appendices 4 and 5 respectively. Table 1 summarises the composition of the government. 
Table 1: Composition of the SL Government in 2008

\begin{tabular}{|c|c|c|}
\hline Central Government & Provincial Government & Local Government \\
\hline $\begin{array}{l}\text { Presidential Secretariat } \\
\text { Parliament -225 members } \\
\text { Judiciary } \\
\text { Ministries -91 } \\
\text { Departments-85 } \\
\text { DistrictSecretariats-25 } \\
\text { Divisional Secretariats-312 } \\
\text { Grama Niladari Divisions- } 11818 \\
\text { Institutions not coming under any } \\
\text { ministry - } 21 \\
\text { Public enterprises - } 210 \\
\text { National Public Service Commission }\end{array}$ & $\begin{array}{l}\text { Provincial Councils- } 9 \\
\text { (elected-8- only } 8 \text { are } \\
\text { operating) } \\
417 \text { councillors } \\
\text { Provincial Ministries - } 40 \\
\text { Provincial High Courts } \\
\text { Provincial Public Service } \\
\text { Commissions - } 8\end{array}$ & $\begin{array}{l}\text { Municipal Councils-18 } \\
\text { Urban Councils - } 42 \\
\text { Pradeshiya Sabhas-270 } \\
\text { Total number of members - } \\
4054\end{array}$ \\
\hline
\end{tabular}

Sources: Auditor General, 2006; Ministry of Provincial Councils and Local Government, 2008; Ministry of Public Administration and Home Affairs, 2007; and Estimates, 2009

In 2001, the $17^{\text {th }}$ Amendment to the Constitution introduced a Constitutional Council (CC) and several independent Commissions such as the National Public Service Commission (NPSC) and the National Police Commission (NPC) to the administrative machinery. This will be discussed in Chapter 5 in detail. The present administrative structure is depicted in Appendix 6.

The following sections examine the key elements of this structure, starting from the executive president followed by the Parliament, Judiciary, Provincial and Local Governments, and the Public Service.

\subsubsection{Executive President}

The Executive President system came into effect from February 4, 1978 (Parliament, 2008). According to Articles 30(1) and 30(2) of the 1978 Constitution, the president is the Head of State, the Head of the Executive and of the Government, and the Commander in-chief of the Armed Forces. Unlike the role of earlier Governors General and the President, the new role of the Executive President is more powerful 
and political than ceremonial. The President is elected directly by the people for a period of six years, and can hold office only for two terms. As the Head of the Executive and of Government the President derives enormous powers and functions ${ }^{10}$ from the Constitution which make him/her "more powerful than the Prime Minister could have been under the former system” (Wilson, 1980, p. 43).

In addition to the ceremonial role, the President has the power to appoint a prime minister, cabinet ministers, non-cabinet ministers, and deputy ministers. The President also has the power to determine the number of ministers and assign portfolios to them and change such portfolios. In the absence of a constitutional cap on the number of ministers, the President can appoint any number of ministers to the Cabinet and outside the Cabinet. The President has the right to assign himself/herself any portfolio. For example, President Jayewardene held the portfolios of Defence, and Plan Implementation (Wilson, 1980). The present President holds the portfolios of Highways and Road Development, Finance and Planning, Defence, Nation Building \& Estate Infrastructure Development, and Religious Affairs. Most importantly, the President can dissolve Parliament after it has served a minimum period of one year (Article 70 of 1978 Constitution).

Under this authority the President can undermine the Government if the Prime Minister and the President do not belong to the same political party. For example, the 2001 UNP Government was weakened by the President Kumaratunga, who was the leader of the SLFP, by taking over the control of the defence, interior and communication ministries from the UNP ministers and suspending Parliament in late 2003 (De Votta, 2003). In this particular incident, the President created a more complicated situation by taking over the Defence portfolio while the Prime Minister had reached a Ceasefire Agreement with Liberation Tigers of Tamil Eelam (LTTE) ${ }^{11}$ in 2002. In February, 2004, President Kumaratunga sacked the UNP government which was expected to govern until 2007 and dissolved Parliament, calling for an election (De Votta, 2004). She did this by using her power of proclamation to

\footnotetext{
${ }^{10}$ Please see Articles 33(a-f), 34,41(1),43(3),44(1a,2 and 3),45(1a),46(1),51,54,65(1),107(1),153(1), 54 and 156(2) of the Constitution, 1978 for more details.

${ }^{11}$ LTTE is a terrorist organisation which fights for a separate state in the north and east part of SL.
} 
summon, prorogue and dissolve Parliament. This shows that ultimate responsibility for maintaining continuity in government lies with the President.

The Constitution empowers the President with some legislative and judicial powers. In relation to legislative powers, the President can act on his/her own to determine when a Declaration of a State of Emergency becomes necessary. Parliamentary approval comes afterwards. In regard to judicial powers, the President is empowered to grant pardon to any offender convicted of any offence in any court within SL.

The President is also empowered to appoint other key positions in government for example, Secretary to the Cabinet, Secretaries to Ministries, the Chief Justice and other judges of the higher judiciary, and the Heads of Army, Navy, Air Force and the Police Force. In addition, the $13^{\text {th }}$ Amendment to the Constitution gives the President more power for appointment of Provincial Governors. However, an attempt was made to curtail some of the President's power under the $17^{\text {th }}$ Amendment to the Constitution (Section 3.2.8).

Article 35 of the Constitution provides immunity to the President from law-suit. Firstly, no legal action can be instituted against the President (whilst he holds office) in any court on any matter. Secondly, the Standing Orders of Parliament do not authorise any reference to be made to him/her or for his/her conduct to be questioned except on a substantive motion (Wilson, 1980). For the last 30 years the president's actions were not challenged by any court of law while he/she was in office. However, in 2008, for the first time the Supreme Court faulted the former president Kumaratunga for abuse of power while she was in office and fined her (Ians, 2008). Thirdly, the President can be removed only through a resolution or an impeachment adopted by two thirds of the total membership of Parliament. Fourthly, the President will not be affected by any adverse vote of confidence against the government in Parliament i.e. "Cabinet goes but the President remains" (Wilson, 1980, p. 44).

Under the present structure, the power of government has shifted from the legislature to the Presidential Secretariat. For example, "the President ignored the existing strictures passed by the Parliamentary Select Committee for selecting the candidates for top public offices" (Wijeweera, 1989, p.294). On many occasions the President 
gave directives on matters and subjects that had been functionally and constitutionally assigned to ministers and some occasions President made decisions on appointments of Chairmen and Board of Directors to public enterprises (Personal observations from 1984-2009, Wijeweera, 1989; Wilson, 1980,). According to Perera (1979), "It is his policy that prevails and has to be carried out by all the ministers including the Prime Minister" (as cited in Wanrnapala, 2004, p.24).

The President maintains firm control on the administration and the ministers through appointing secretaries to ministries at the centre and appointing Governors at the provinces. President Jayewardene obtained undated resignation letters from the Members of Parliament of his party as a control mechanism. The most critical factor of the Executive President System is that Parliament came to be devalued and the Executive 'one man show' overrides collective responsibility of the Cabinet.

In summary, the Executive President is the apex of the SL government structure and is over-empowered by the 1978 Constitution, leading to dictatorial tendencies. As the former President Jayewardene boasted, the only thing that the executive President cannot do is to turn a woman into a man (Rahman, 2005, p.8).

\subsubsection{Parliament}

The Parliament of SL is unicameral with 225 members of whom 196 are elected and 29 nominated by competing political parties in proportion to their share of the national vote. Elections are held under universal suffrage and proportional representation involving preferential voting for a state of candidates nominated by different political parties/groups. Parliament's term is for a maximum period of six years. Constitutionally, Parliament is the supreme institution that has control over legislative agenda and budgetary allocations. However, in practice effective control over legislation and budget has been taken over by the President. There are no checks and balances by the legislature over the actions of the President, except of course, a very difficult procedure of Impeachment. 
Parliament is highly susceptible to presidential dictates and to the political circumstances of the day. This brings a high degree of uncertainty and instability. There were political conditions which forced elections before the expiration of the period government; for example, both the 2000 SLFP and 2001 UNP governments fell and fresh elections were held due to volatility in party politics in Parliament and the use of the power of dissolution held by the President respectively.

\subsubsection{Organisation of the Parliament}

The formal organisation and procedures of the SL Parliament follow British parliamentary practices. The majority of legislative responsibilities are delivered through Committees. Currently there are seven committees for special purposes: Committee on Selection, Standing Orders, Public Accounts, Public Petitions, Privileges, Parliamentary Business, and Public Enterprises. In addition, there are 55 Consultative Committees (Parliament of Sri Lanka, 2008). The underlying concept for having these committees is that they provide adequate safeguards to secure the proper use of delegated legislative powers by executive bodies.

Of those Committees, three are important in this study: the Consultative, Public Accounts, and Public Enterprises, because they represent parliamentary oversight of the executive and allow a direct relationship between public officials and legislature.

\subsubsection{Consultative Committees}

The Committee of Selection, at the commencement of every session of Parliament, appoints consultative committees based on the number of cabinet ministries. This number has been increased due to proliferation of ministries over the years; for example; in 1996 there were 25 consultative committees. In 2000 this number was increased to 45 (Warnapala, 2004). Today this number has further increased to 55 (Parliament of Sri Lanka, 2008).The objective of these committees is to discuss both the formulation and implementation of policies of ministries, thereby increasing the efficiency of public institutions. However, in practice participation of members in committee meetings is very week, and they discuss matters relating to their individual interests rather than implementation of policies, so that the performance of these committees so far is inadequate. (Personal observation). 
According to Warnapala (2004, pp. 49-50),

A few interested MPs with a number of issues which have a direct relevance to constituency needs and grievances attended the meetings for example, appointments, promotions, and basic electorate needs such as construction of schools, hospitals, shortage of teachers dominate in meetings. They got the opportunity to criticise or praise the members of bureaucracy who were present and their commissions and omissions were discussed. The Committees did not play a role in reviewing administration and they failed to play a role in initiating any legislation though on certain occasions certain initiatives were taken on as matters of national importance.

In essence it is the intention of the members to discuss specific administrative decisions rather than function as legislative oversight committees. As expected, these committees do not seem to exercise their legitimate role i.e. legislative oversight over administrative activity.

\subsubsection{Committee on Public Accounts (COPA) and Committee on Public Enterprises (COPE)}

The parliament, through COPA and COPE, examines the Auditor General's (AG) report thoroughly to ensure financial accountability in public business. Both committees are composed of 24 members, 12 each from the ruling party and the Opposition, nominated by the Committee on Selection. The committees' main mandate is to review the annual audit reports of the Office of the AG. COPA is responsible for reviewing annual reports of the $A G$ in regard to ministries, departments and other government agencies while COPE is entrusted with overseeing public finance in regard to public enterprises (PEs) such as Ceylon Electricity Board and SL Ports Authority.

These Committees emerged from the notion of public accountability that

on behalf of the public, the Parliament, is fully empowered to exercise highest level of supervisory control over public resources including public finance made use by the executive in conformity with legislative provisions made by Parliament through the Annual appropriation Act and all other applicable statutes, in order to make sure that such resources are being made use economically, efficiently, and effectively, i.e. To (sic) ensure optimum utilisation of the resources for achieving the intended objectives for improving the well being of the general public, the owners of these resources (Auditor General, 2006, p.19). 
Figure 2 below describes how COPA and COPE fit into the process of public accountability in SL.

\section{Figure 2: The Process of Public Accountability}

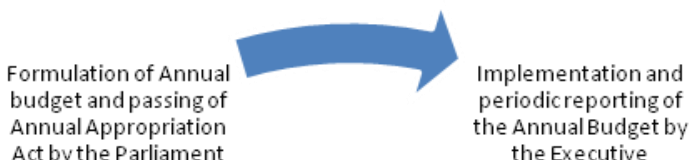

$$
\text { Annual Appropriation the Annual Budget by }
$$
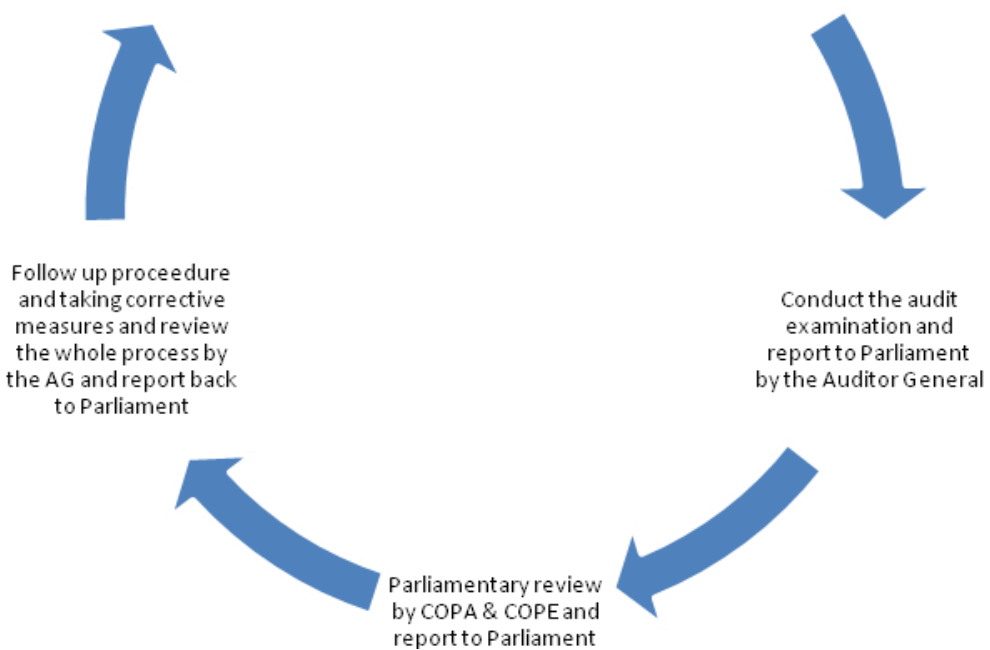

Source: Auditor General, 2007, p. 10

Formally, Parliament has power to approve the budget of the Government each through the Annual Appropriation Act. Once it is approved, the Ministry of Finance is responsible for its effective implementation in its entirety while other ministries are liable for implementing their respective components. The AG is constitutionally responsible for the review of accounts of public institutions: ministries, departments, public enterprises and business undertakings and report to parliament. This report includes findings on matters related to non-compliance, deficiencies in systems and procedures, misuse of money and other resources, corruption or fraud. However, this report does not cover the overall efficiency and the effectiveness of the use of public money due to a lack of performance audit system. The SL financial management system does not classify expenses by output or outcome. Therefore, the expectation of the use of public funds efficiently and effectively (in the SL context) as mentioned by the AG is limited. The Standing Orders of parliament facilitate the COPE and COPA to request any information they need to carry out their functions effectively. 
Conventionally, investigations are confined to those points highlighted in the AG's report, but the committee has the power to go beyond that if needed.

COPA and COPE summons the Chief Accounting Officers (Secretaries of Ministries), Accounting Officers (Heads of Departments), and executives of Public Enterprises in their deliberations. The increased involvement of government activities in all spheres in the economy and the proliferation of ministries have increased the volume of work of COPA. The complexity of issues in the public organisations such as changes of functions and changes in ministries and departments are so often key challenges faced by the COPA today (Auditor General, 2006; Warnapala, 2004).

Professor Wiswa Warnapala who has been the Chair of the COPA from 1995-2000, in his Parliament and Public Accountability in Sri Lanka (2004), mentioned that there are a number of deficiencies that hinder effective deliberation. These include poor attendance, inattention to policy matters, lack of interest due to bulky nature of estimates and tiring processes to go through them, few opportunities to discuss matters in detail, no clear understanding among political parties on matters pertaining to the proper utilisation of the Committee Stage, inadequate technical capabilities of the parliamentary staff in facilitating the members, limited information, hesitancy of Chief Accounting Officers to divulge sensitive information, narrow scope of their functions, and lack of time to study the reports submitted by the ministries.

In addition, there are other policy issues in relation to committee meetings. Unlike other Commonwealth countries, COPA and COPE deliberations in SL are not transparent. "Because of provisions in section 130A of the Standing Orders and section 17 of the Parliamentary Powers and Privileges Act, neither the public nor the media are allowed to witness the proceedings" (World Bank, 2003, p. 40). They are held 'in camera'. This situation hinders their effectiveness. There is no incentive for the members of these two committees to meet regularly, prepare adequately for meetings, conduct qualitative performance review, and have useful and meaningful dialogue. Meetings were postponed owing to lack of a quorum, and the Committee faced the problem of a backlog of audit reports for review. Therefore, the Committee 
was inclined to bunch reviews together. The World Bank (2003, p.40) highlighted that,

on review of COPA agenda for a particular meeting, it was revealed that just over an hour was allocated for reviewing the audit reports of four agencies with expenditure over $\$ 11.5$ million, while COPE, for just one day summoned 15 corporations.

However, unlike in the past, the committee reports have now been published. The COPA and COPE 2007 reports are noteworthy and will be discussed in Chapter 4 .

Overall there is a lack of commitment in the operation of committees. According to Warnapala (2004), during 1948-1970 there were seven Select Committees to embark on the revision of the Constitution but none produced a report on the revision.

\subsubsection{Judiciary}

The Judicial system also plays a key role in the public sector. The Constitution of 1978 guarantees the independence of the judicial system, which has the fundamental responsibility to preserve democratic values (Articles 107,110,112, 115, 116, and 117). Appointment, transfer, dismissal, and disciplinary control of judicial officers ${ }^{12}$ and other public officers serving within the judicial system are vested with the Judicial Service Commission, which is composed of three members: the Chief Justice as the Chairman and two other Supreme Court Judges. In addition to independence, the Constitution requires the judiciary to be open in their proceedings by requiring every court to be held in public, and all persons being entitled to attend freely.

\subsubsection{Role of the Courts in Administrative Matters}

Public officials and institutions are required to be 'fair in action' and maintain the "principles of administrative law in decision making: principle of natural justice ${ }^{13}$, the rule that requires a decision maker to hear both sides, and the requirement that a

\footnotetext{
12 "Judicial officer" includes all officers except a judge of a Supreme Court or of the Court of Appeal or of the High Court.

${ }^{13}$ Natural justice is the concept of fairness: justice must not only be done but must appear or seen to be done.
} 
person must not be a judge in his own cause and the doctrine of ultra vires or beyond the powers" (Weerasooria, 2004, p. 146). Public organisations, including courts, are obliged to safeguard the fundamental rights of the people in their decisions and actions. When their decisions and actions are flawed the higher courts namely the Supreme Court and the Court of Appeal have the power to correct them. Article 141 of the Constitution empowers the Court of Appeal to issue writs ${ }^{14}$.

As in the case of other countries the court system in SL is costly and experiencing excessive delays in concluding proceedings (Weerasooria, 2004). Therefore, the $17^{\text {th }}$ Amendment to the Constitution (2001) introduced an Administrative Appeals Tribunal (AAT). A separate Act, the Administrative Appeals Tribunal Act, No. 4 was passed in 2002 and the members were appointed by the Judicial Service Commission for a term of three years. It is composed of three members, including the Chairman, and vested with powers to hear any appeal referred to it by an aggrieved public or police officer regarding any order or decision made by the National Public Service Commission (NPSC) and the National Police Commission (NPC) respectively. It also has the power to alter, vary or rescind any order or decision and to call for any reports, documents, or other materials. The decisions of the AAT are final and cannot be questioned in any court of law. The independence of the Tribunal is ensured by the Constitution. In this respect, no suit can be filed against the Tribunal in any lawful act done or omitted to be done in good faith. Therefore, it is an improvement on the provisions of the 1972 and 1978 Constitutions, which will be discussed in Chapter 5. Accordingly, public officials and police officers now have the opportunity for further appeal without much cost or delay. In the recent past, the involvement of judiciary in public administrative matters has been limited. This will be discussed in detail in Chapter 4 .

\footnotetext{
${ }^{14}$ Writ of Certiorari: quash or cancel an illegal, unjust or a wrongful decision; Writ of Prohibition: stop a public officer or a body from arriving at a wrongful decisions; Writ of Habeas Corpus: direct people to be produced before courts when any person improperly detained in public or private custody; Writ of Mandamus: direct the public official or state body to arrive at a particular decision.
} 


\subsubsection{Provincial Councils (PCs)}

The PCs have become the second tier of the administrative structure of SL from November 1987 with the devolution of political and administrative power to the subnational level under the $13^{\text {th }}$ Amendment to the Constitution. The evolution of PCs will be discussed in Chapter 5.

This constitutional reform brought radical changes to the centralised form of governance which SL inherited from its colonial masters. The $9^{\text {th }}$ schedule of the $13^{\text {th }}$ Amendment to the Constitution indicates the 'devolved subjects' under List I, whilst categorising the 'reserved subjects' for the central government under List II. It specifies the reserved subjects as "national policy on all subjects and functions". List III specifies the 'concurrent subjects' coming within the jurisdictions of the centre and the provinces. Subjects in List I and List III ${ }^{15}$ can overlap and have been matters for controversy as well as conflict between the central government institutions and the PCs. This will be discussed in detail in Chapter 4.

Until 2007, there were 7 elected PCs with 380 members - Central (58), Western (104), Southern (55), North Central (33), North Western (52), Uva (34) and Sabaragamuwa (44). The North and East provinces which were merged by the IndoLanka Accord in 1989 have separated, as per the judgment of the Supreme Court of October 16, 2006, into two separate provinces (the North Province and East Province) after a period of approximately 20 years (Eastern Provincial Council, 2009). The administration of the two provinces was brought under two Governors from January 1, 2007. After the liberation of the Eastern Province from the LTTE, the PC election was held in May 2008. A break-away faction of LTTE contested the election in alliance with SLFP (governing party) and established the Eastern PC, thus a former LTTE insurgent in the East became the Chief Minister of that province (Wickramasinghe, 2009). Accordingly, there are eight elected PCs functioning at present. The setting up of an elected PC in the North, which has been run by public officials since 1990, may be possible after resettlement of the displaced people of the North.

\footnotetext{
${ }^{15}$ For details see the ninth schedule of the $13^{\text {th }}$ Amendment to the Constitution of 1978.
} 


\subsubsection{Organisation and Powers of the Governor}

The PCs are organised in the way that the ARC of 1986/88 recommended. Accordingly, each province has its Governor appointed by the President, a Council elected by the people of the Province, and a Board of Ministers, headed by a Chief Minister (CM), who is responsible for the Council (Appendix 5). The Provincial Governor is the apex in the PC set-up. He holds office "during the pleasure of the president" for a term of five years ("The Constitution of Sri Lanka, 1978”).

As in the case of Executive President of SL, the Governor of the province derives direct executive powers from the Constitution. They include the powers to appoint the $\mathrm{CM}$, summon, prorogue or dissolve the Council (subject to the advice of the $\mathrm{CM}$ ), make laws, rules and regulations, and make a report to the President on an errant PC. Furthermore, he is empowered to determine all matters relating to members of the Provincial Public Service, including the formulation of schemes of recruitment, appointments, promotions, transfers, dismissal, and disciplinary control for such officers ("The Provincial Councils Act No. 42 of 1987"). The Governor can delegate these powers to the Provincial Public Service Commission (PPSC). The PPSC in turn can re-delegate its delegated power to the Chief Secretary or to any officer in the province.

The PC Act requires the Governor to appoint three persons for a period of five years to the PPSC. One of them will be nominated as the Chairman of the Commission by the Governor. Accordingly, the PPSC is not an independent body. According to Article 33 (8), the Governor of the province has the power "to alter, vary, and rescind any appointment, order of transfer, or dismissal or any other order, relating to disciplinary matters made by the PPSC of that province." As such the Governor can legally manipulate the decisions of the PPSC and bring political justifications into such matters. Thus, the future of a Provincial public servant is dependent on the decision of the Governor, who is a nominated political figure, sometimes a singer, actor, lawyer, retired member of the police service or armed forces, a defeated MP or minister, or anybody. 
The legislative power of the province is vested with the Council. Each PC functions through a Board of Ministers consisting of the Chief Minster and four other ministers appointed by the Governor. The Board of Ministers is collectively responsible and answerable to the PC.

The Governor allocates responsibilities among the Ministers on the advice of the $\mathrm{CM}$; for example the CM, Western Provincial Council is entrusted with Finance, Planning, Employment, Law and Order, Education, Cultural and Art Affairs, Local Government and Provincial Administration and Transport- Western Province. The other four are:

Lands, Agriculture, Minor Irrigation, Animal Production, Health and Tourism activities;

Health, Indigenous Medicine, Social Welfare, Probation and Child Care;

Electricity, Provincial Roads, Co-operatives and Trade, Food and Water; and

Sports, Youth Affairs, Women's Affairs, Fisheries, Rural Industries, Rural Development and Rural Institutions, Housing and Constructions (Western Provincial Council, 2009).

The allocation of tasks to ministries has no coherence; for example, Animal Production is dealt with by one ministry while Fisheries are dealt with by another ministry.

\subsubsection{President's Power over PCs}

The President also has power in regard to PCs. Under the $13^{\text {th }}$ Amendment to the Constitution the President is vested with powers to take over the administration of the PC under himself or the Parliament if the President "is satisfied on a report from the governor or otherwise, that a situation has arisen in which the administration of 
the Province cannot be carried on in accordance with the provision of the Constitution" (Article 154L of the Constitution, 1987). When the powers of the PC are conferred on Parliament, the President is empowered to authorise expenditure from the Provincial Fund with the approval of Parliament.

Furthermore, in times of emergency the President can declare that all executive and legislative powers of the PCs will be exercised by him or by Parliament. In addition, the central government can pass regulations to override, amend, or suspend the operation of a PC's statute. These provisions are inevitable because the PCs are set up under the unitary structure of the Republican Constitution. These powers have been highly criticised by the Tamils since the inception of PCs because they expected full autonomy in PCs' administration. Therefore, the role of the President in maintaining the balance between central government control to safeguard the unitary structure and fulfilment of the aspirations of the Tamils through the PC system, even after winning the war against the LTTE in May 2009, is not insignificant but vital.

\subsubsection{Divisional Secretariats}

The unique feature in the administrative decentralisation was the creation of Divisional Secretariats. The powers enjoyed by the Government Agents (GA) in districts under different legislations were statutorily transferred to the Divisional Secretaries (DSs) by the Transfer of Powers (Divisional Secretary) Act No. 58 of 1992. This position gives autonomy to DS. Under the delegated power of the NPSC, the Ministry of Public Administration and Home Affairs deals with the appointment, promotion, transfer, disciplinary control, and dismissal of the DS. Accordingly, the primary loyalties of the DS lie with the centre. The DS, being an officer of the central government, becomes core administrator in the periphery by fulfilling dual roles - central and provincial. He/She reports to the Chief Secretary at the Province on devolved responsibilities but maintains the role of Assistant Government Agent, representing the GA for non-devolved subjects. This office facilitates almost all the public services to local people; for example, issuance of birth, marriage and death certificates, licences, and provision of social services. 


\subsubsection{Local Government}

With the introduction of the PC system, local governments became the third tier of the administrative structure in SL. They consist of Municipal Councils (MCs), Urban Councils (UCs) and Pradeshiya Sabhas (PSs) with 4054 elected members (Ministry of Finance and Planning, 2009). Basically, the MCs are established for major cities, UCs for large but less urbanised towns and PSs for the rural areas. Although it is usually considered that MCs and UCs are 'urban' and PSs are 'rural' local authorities, there is no formal definition of the terms 'rural' and 'urban' in the SL context (Commission of Inquiry on Local Government Reforms, 1999, p.39).

These three institutions execute their legitimate functions deriving powers from their respective Ordinances and other laws: the Constitution (Article 154), various enactments, Provincial Council Statutes, subsidiary legislations. The central Ministry of Provincial Councils and Local Government formulates the major policies in relation to local governments while exercising close scrutiny over their activities. As a result, there have been occasions where the chairmen of council were removed, or an entire council suspended or dissolved on Ministry findings of malpractices and incompetence; for example, the Colombo MC was dissolved in November 2008 and its affairs is administered by the City Commissioner ("Sri Lanka Government suspends Colombo Municipal Council ”, 2008).

The $13^{\text {th }}$ Amendment to the Constitution puts the 'local government' in List I as mentioned before. Therefore, PCs also have the power to make statutes in relation to local authorities. However, that power is limited. Under Article $154 \mathrm{G}$ of the $13^{\text {th }}$ Amendment to the Constitution, the PCs are empowered to legislate "additional power on local authorities but not to take away." Therefore, PCs cannot reduce the powers of local authorities.

\subsubsection{Public Service}

The SLPS is the major contributor and key employer in realising development goals. History reveals that at the dawn of Independence (1948) SL had a well trained, 
experienced and capable bureaucracy, independent public service and a coherent administrative system (Kearney, 1973).

Since then SLPS has expanded with an extensive range of new functions and responsibilities. As a result, the public service has been confronted with many challenges and serious repercussions over time and has been subjected to political, economic and social stresses. Ever-increasing political involvement and interference in all sectors in the public service have been the major bottleneck for development and reforms, and have "impaired internal systems and processes" (Presidential Commission on Youth, 1990). Many elements of the bureaucracy and administration also led to this situation. The public service has been subjected to criticism by the public, private sector, international agencies, and politicians for lethargy, inefficiency, ineffectiveness, insensitivity to public needs and wants, corruption, lack of initiatives and being reactive rather than proactive, and backward-looking (ARC, 1986/88; COPE, 2007; Kearney, 1973; Root et al., 2001; Presidential Commission on Youth, 1990; World Bank, 2003).

Despite these problems, the SLPS comprises much of SL's talent and inspired expertise, men and women with diligence, which is an important factor for the progress achieved so far, and hope for future reforms and progress, despite uncertainty in the country.

SLPS is composed of the State Sector, the Provincial Public Sector, and the SemiGovernment Sector. The State Sector includes all the ministries and departments coming under the purview of the central government while the Provincial Public Sector includes the ministries and institutions functioning under the PCs. The SemiGovernment Sector includes the Co-operations, Statutory Boards, Authorities, and State Banks under the Central Government, and Public-Private Companies.

SLPS is stratified into three levels on the basis of status and pay: managerial, subordinate employees, and minor office employees. The managerial level is composed of administrative, professional, and technical officers, termed "staff officers" with managers in the 'All Island Services' (AISs), managers not belonging to any of the AISs and managers who do not come under any Ministry. The AISs 
include 11 parallel services (Appendix 7). The "subordinate employees" include management assistants, translators, and a number of other categories of public servants. The Management Assistants Service was created in 2005 by the amalgamation of several parallel subordinate services. This will be further discussed in Chapter 5. At the bottom of the hierarchy, termed "Office Employees", are lower grade workers such as peons, messengers, and labourers.

All these services are called 'Combined Services,' which supply human resources to the government ministries, departments and institutions in the central government as well as to the provincial governments. Thus, employees in these services are transferable to any part of the country.

\subsubsection{The Constitutional Council (CC)}

The CC was added to the administrative structure in 2001 by the $17^{\text {th }}$ Amendment to the Constitution. It is the apex of the new constitutional regime in relation to the public service. The CC comes within the ambit of parliament with the Speaker as its Chairman and nine other members: the Prime Minister, the Leader of the Opposition, one person appointed by the President, five persons appointed by the President on joint nominations of the Prime Minister and the Leader of the Opposition, of whom two shall be nominated to represent minority communities and interests, and one person nominated by the MPs of the small political parties or independent groups who do not belong to either the PM's or the Leader of the Opposition's parties. The Constitution requires a mandatory process of consultation with the leaders of political parties and independent groups represented in Parliament for these nominations.

Article 41B (1) of the $17^{\text {th }}$ Amendment to the Constitution states:

No person shall be appointed by the President as the chairman or a member of any of the Commissions specified in the schedule to this Article, except on a recommendation of the Council.

With the agreement of the $\mathrm{CC}$, therefore, the President can appoint the members and chairmen of the Election Commission, National Public Service Commission, 
National Police Commission, Human Rights Commission, Bribery and Corruption Commission, Finance Commission, and Delimitation Commission.

Article 41C (1) states,

No person shall be appointed by the President to any of the offices specified in the schedule to this Article, unless such appointment has been approved by the Council upon a recommendation made to the Council by the President.

The schedule includes the Chief Justice, Judges of the Supreme Court, President and the Judges of the Court of Appeal, members of the Judicial Service Commission other than the Chairman, Attorney General, Auditor General, Inspector General of Police, Parliamentary Commissioner for Administration (Ombudsman), and Secretary General of Parliament. According to this Amendment, the President now cannot appoint anyone to those positions without the approval of the $\mathrm{CC}$. Under Article $41 \mathrm{C}(4)$ the Council has to obtain the views of the Chief Justice and the Attorney General relating to the appointments of Judges of the Supreme Court and the President and Judges of the Court of Appeal. In the execution of its functions on recommendation, approval or decision, the Council should try to act unanimously. In the absence of unanimity at least five members should support a decision.

Accordingly, the President's power in relation to key appointments envisaged by the 1978 Constitution was restricted by the $17^{\text {th }}$ Amendment. Although the Amendment was passed in 2001, the CC was finally established in March 2002. It recommended members for the NPSC, Police Commission and Election Commission to the President. The President appointed members only to the first two Commissions (Wijeweera, 2006). Due to a controversy between the President and the CC over the nomination of the Chair of the Election Commission, this was not established and is yet to be realised.

The tenure of the CC members was three years, which ended the first Councillors' term in March 2005. From that date up to this writing, the CC ceased to operate due to non-appointment of its members by the President. Until January 2007, this was delayed due to non-consensus of the minority parties over one member (one person nominated upon agreement by the majority of the MPs belonging to political parties or independent groups other than the respective political parties or independent 
groups to which the Prime Minister and the Leader of the Opposition belongs and appointed by the President).

Dr. B.S. Wijeweera, former GA, in an interview responding to the claim of minority parties said that,

Ultimately what you have to have in the $\mathrm{CC}$ are good people of integrity. It matters very little whether that person of integrity is nominated by one party or the other. They are sticking to the claim that this person should be appointed by me or no one else. In my view, it is a silly argument. What you have to find are good people of integrity who can be vested with that responsibility. Does not matter who proposes ultimately if you can agree that the individual is good (Interview, 09.01.2008).

He further said,

On the first occasion when it was implemented, Parliament was very magnanimous and they supported by nominating their representatives to the Council. On this occasion because of the disunity of the Parliament they were unable to nominate one person. The unity which gave rise to the setting up the Council was not there now, then somewhere it will breakdown. That was made use of by the President (Interview, 09.01.2008)

Because of this problem, the two Commissions, the NPSC and the Police, were out of office with the expiry of the terms in November and December 2005 respectively. In the absence of the $\mathrm{CC}$, there was an uncertainty in their re-appointments. As a result, the President took the liberty and used his discretionary power to appoint members to these institutions on his own because of the urgent need of such action, although it was not the correct procedure to follow.

Eventually, in January 2008 all the minority parties agreed to nominate the former $\mathrm{AG}$ to the $\mathrm{CC}$, but this nomination was not accepted by the government, saying that he is currently employed in one of the Projects in Parliament. In the meantime, the Prime Minister announced in Parliament that the government will not establish the CC until the recommendations of the Parliamentary Select Committee appointed on September 6, 2006 "to look into the operation of $17^{\text {th }}$ Amendment to the Constitution", finalise and make further amendments to the Constitution addressing the existing shortfalls. According to one respondent ${ }^{16}$ of this study, the report of the Select Committee was lying on one of the desks in Parliament. The Opposition is of the view that the President should act according to the present Constitution, thus he

\footnotetext{
${ }^{16}$ In this case the respondent is to be anonymous.
} 
violates the Constitution by not appointing members already nominated and he should not wait until further amendments. The lack of political will on reform due to unwillingness of the executive to lose his power has jeopardised the spirit of the reform. This also shows that accountability is lacking in the political system of the country. The evolution and problems of $\mathrm{CC}$ will be further discussed in Chapter 5 .

In other jurisdictions such as New Zealand, the United Kingdom and Australia public sector reforms were initiated by ministers, public servants or major reviews. Against the above backdrop, it is very difficult to imagine that such initiatives in SL could be made without the support of the Executive President.

\subsection{Conclusion}

This chapter introduced the structure and functioning of the SL's government at three levels, the centre, province and the local level. It also explained the powers of the executive, legislature and the judiciary in relation to public administration which is the main focus of this study. Further, it described composition of the public service in brief along with the introduction of the new agency, CC.

The outstanding feature of the structure is the power of the President. The position has wide-ranging, centralised executive power. It flows through the administrative structure from the central government agencies, through the ministers and the secretaries of ministries to the provincial administrative set-up through the Governors and the President's reserve powers in respect of provincial councils. The effective growth of the President's power over legislature and in some areas of the judiciary is also enormous. This authority of the President over all spheres of the administrative machinery undermines the legislative power to a greater extent and hinders the effective checks and balances by the legislature over the executive. Moreover, the current structure lacks an overall coordination body for central, provincial and local government functions. 


\section{Chapter 4: The Current Situation of Public Administration in SL}

\subsection{Introduction}

Having discussed the structure and process of government in SL, this chapter reviews the current functioning of the public administration in SL and highlights issues in the present system that need to be addressed. Therefore, the main objective of this chapter is to identify and discuss the current problems in public administration in SL.

This chapter has three parts. Part I discusses the scope of public administration, structural and service delivery deficiencies in the current setup, both central and provincial governments, and their implications for public administration. The interventions of the Supreme Court in correction of mistakes in service deliveries are also highlighted. This part then discusses some positive aspects of country's public administration with a view to highlighting that there are possibilities for future reforms. Thereafter, it evaluates the performance of public enterprises.

Part II examines the numbers of people deployed to carry out those roles and responsibilities, their costs, the manner in which those cadres are managed including appointments, manpower planning, transfers, promotions, performance management and training. Part III reviews other critical areas in public administration such as corruption; trade unionism; shortfalls in systems and procedures and financial management systems. The objective of the analysis is to understand the complexity and specificity of the present situation. 


\subsection{Part I: Scope of Public Administration, Structural and Service Delivery Problems, Positive Aspects of SL's Public Administration and Public Enterprises}

\subsubsection{Scope of Public Administration}

The key tasks performed by the government through the administrative system are: provision of public goods, and services: fiscal management: maintenance of law and order; facilitation of economic activities; policy management; regulatory measures that need to be taken to safeguard the consumers, industries, labour force, investors, and the environment.

The primary objectives of the government are the promotion of economic development and social wellbeing of the citizens through effective policies, and efficient delivery of such roles and functions. Accordingly, public administration has an implicit and explicit role in achieving the above objectives.

Nevertheless, many of the functions that are currently performed by the administrative institutions could, after almost three decades of a changeover to a market economy, be equally effectively performed by the private and nongovernmental agencies (Wanasinghe, 2005) or through public-private partnerships with proper guidance and regulations. The continuous retention of those functions by the government is a major setback due to lack of willingness to cede the advantage of power by the political and administrative cadres.

Therefore, the role of the SLPS has to be viewed in the context of policy changes that have been taken place in the economy in 1977, and also administrative apparatus in 1989, which had direct bearing on public administration. When market liberalisation, deregulation, corporatisation and privatisation commenced in 1977, state intervention and the role of the government should have been reduced to the role of a facilitator and a regulator. However, these reforms were done in isolation, without 
commensurate changes in the administrative system, which was a necessity for its effectiveness.

Vijitha Herath, MP, JVP, in an interview, remarked,

With the open economy policy our Financial Regulations, Establishment Code and administrative systems should have been changed in commensurate with that change. But it did not happen. In Singapore when they open the economy they changed the management of the administrative system in parallel to suit that change. Since SL did not do such things, people faced problems. When they go to a public office, there are always delays in service and there are no systematic approaches. When they go to a private institution they found that they are treated better. Therefore, a strong criticism emerged to say that public sector is inefficient and useless (Interview, 18.01. 2008).

The open economy policy has been carried out by successive governments irrespective of the political party in power. However, privatisation was abandoned with the change of government in 2005 under the 'Mahinda Chintana' philosophy (Minister of Finance and Planning, 2006), so that the role of government once again was set back to pre-1977 period: the policy maker, service provider, facilitator, controller, and regulator.

Similarly, SL followed the policy of decentralisation of administration from the early 1970s which created deconcentrated administrative structures. The policy of devolution was adopted with the passing of the $13^{\text {th }}$ Amendment to the Constitution in 1987. With devolution of power some of the powers and responsibilities of the centre were handed over to newly-created Provincial Councils as mentioned before. Accordingly, the administrative units of the central government had to be reduced in theory but in practice they have increased and continue to perform through central agencies. Thus, the control of such functions is still retained by the ministries because this change did not accompany a vigorous institutional restructuring - "What was effected was an attempt to tinker with the existing partially deconcentrated institutional structures that were directed from the centre" (Wanasinghe, 2005, p. 3). This attempt was unplanned, hurried, and manipulated by India, mainly as a solution to the ethnic problem in the country with a desperate urgency to show that devolution had taken place from the centre to the provinces (see 5.4.10 for details on evolution of PC). This unplanned exercise generated many deficiencies in current public management which will be discussed next. 


\subsubsection{Structural and Service Delivery Problems (Centre and Provinces)}

At present, there are several deficiencies in the administrative structure and service delivery mechanisms. The lack of real autonomy below the centre and proper coordination, parallel institutional structures, proliferation of ministries, duplication of functions and a large numbers of public enterprises are some of them which will be discussed in detail below.

\subsubsection{Structural Problems}

\section{Lack of Real Autonomy of Authority and Responsibility below the Centre}

The essence of devolution depends on the extent to which it allows the PCs to take decisions in the exercise of powers that are explained in the enactment (Gunawardane, n.d). The 'national policy on all subjects and functions' in the Reserved List of the $9^{\text {th }}$ schedule of the $13^{\text {th }}$ Amendment to the Constitution has been always used by the Centre to control the actions of the PCs. In addition, the lack of effective authority over finances, human resources, and enactment of statutes by the Provinces has contributed to the weakening of the provincial administration.

\section{Financing}

Each PC has a Provincial Fund for financing. It is composed of revenue earned by the province from the devolved subjects and financial grants and loans from the Centre. The Provincial List does include a narrow revenue base for most of the Provinces except the Western Province ${ }^{17}$, thus imposing serious financial constraints on the Provinces. According to the World Bank (2003, p. 21), the PCs depend on the Central Government for more than $80 \%$ of their financing needs.

\footnotetext{
${ }^{17}$ The Western Province composed of Colombo, Gampaha and Kalutara administrative districts with 5.6 million population (2007) is the economic hub of the country. .
} 
In an interview, Dr. B.S. Wijeweera, former GA, said,

Another major issue which is unresolved yet is centralisation of revenue in the central government. Import duties, taxes and excise duties are centralised. The provinces find it difficult to get the wherewithal to carry out their functions and administration, so any strategy to devolve functions to outstations you have to give them viable financial mechanisms where they can generate sufficient revenues in order to run their administration. Now it is not there (Interview, 09.01.2008).

Administratively those funds are transferred to the PCs through the account of a central line ministry, the Ministry of Provincial Councils and Local Government by the Treasury, which is also a matter of concern. Of even greater concern is the involvement of the Finance Commission which is appointed by the President for the recommendation of the budget transfers to the Provinces. It represents only the central views. One of the interviewees ${ }^{18}$ of this study mentioned that the decisions of the Finance Commission are influenced and dominated by its two ex-officio members, the Governor of the Central Bank and the Secretary to the Treasury.

According to the World Bank (2003), the financial constraints at the Centre, weak capacity of the Finance Commission, and dependency on the Central Government have made provincial budgeting ineffective. According to Fernando, the financial constraints in the Centre further exacerbated timely disbursement to the provinces (Interview, 09.01.2008).

Figure 3: Financial Releases by the Treasury to PCs from 2005-2008

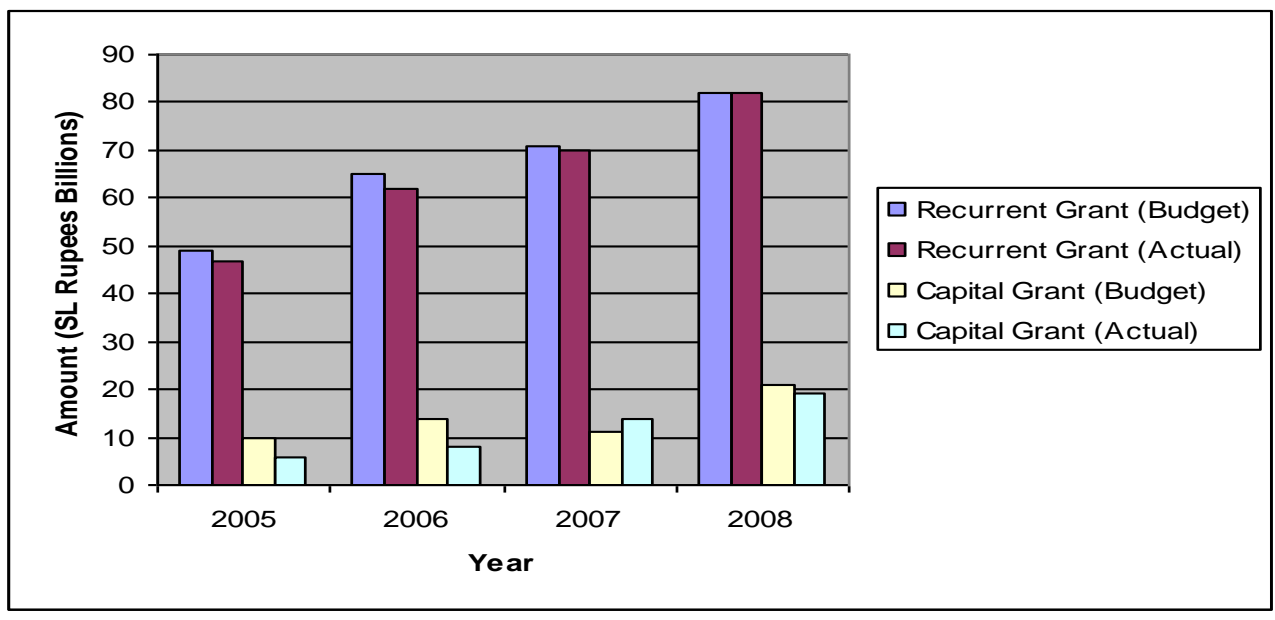

Source: Ministry of Provincial Councils and Local Government, 2008 and Estimates, 2009

\footnotetext{
${ }^{18}$ In this case the interviewee wanted to be anonymous.
} 
According to Figure 3, a large sum of money (88\%) has been allocated and released for recurrent expenses including salaries and other maintenance costs whilst insignificant amount has been allocated and released to PCs by the Treasury for capital work (12\%) from 2005-2008. The current civil service salaries of the PCs alone accounts for over $65 \%$ of their total expenditures. The limited fiscal decentralisation has resulted in limited progress in the PCs, thus, their existence is problematic. In an interview, Dr. Abeywardene, former GA said, "Huge amount of money is spent for survival of the PCs. It is in fact a waste of money" (Interview, 22.11.2007). However, under the present circumstances in the country effective PCs would be desirable.

According to the Ministry of Provincial Councils and Local Government (2008), there are regular delays in disbursements of funds by the Treasury. These constraints ultimately contribute to negative effects and shortfalls in the development agenda of the Provinces. The PCs complain that the monthly disbursement of funds is hardly sufficient to meet their commitments and liabilities which in turn affect their credibility and image. However, in certain instances a lack of proper financial control by the PCs has led to mismanagement of funds.

Vijitha Herath, MP, JVP, commented on the flow of finance to the PCs,

The finance flows from the Centre to the Provinces' duplicate functions. Funds comes from the Treasury to the Line Ministry [Provincial Council and Local Government] and then to PCs. There are people to handle such function in each set-up, thus duplicating work.

In addition, if the Central Government is one party and the PC is another party, the financial allocation is always curtailed. This is same even for Pradeshiya Sabha. If the PC is SLFP and the Pradeshiya Sabha is UNP money is cut to prevent them strengthening their political base. Unfortunately the public does not get required service due to conflict in the political authorities in three levels (Interview, 18.01.2008).

Further, there is an inequality of revenue base. In 2008, the total revenue of PCs was SLRs 21455 million, of which Western PC accounted for SLRs 13147 million whereas Uva only accounted for SLRs 618 million. According to Figure 4, the North/East accounted for a negligible amount of revenue, SLRs 41 million. Accordingly, the inequality of revenue base in provinces leads to inequality in development. This huge gap between provinces in the development ultimately leads to discrimination of access to opportunities for goods and services to the public in those areas. 
Figure 4: Devolved Revenue by the Provinces from 2004-2008

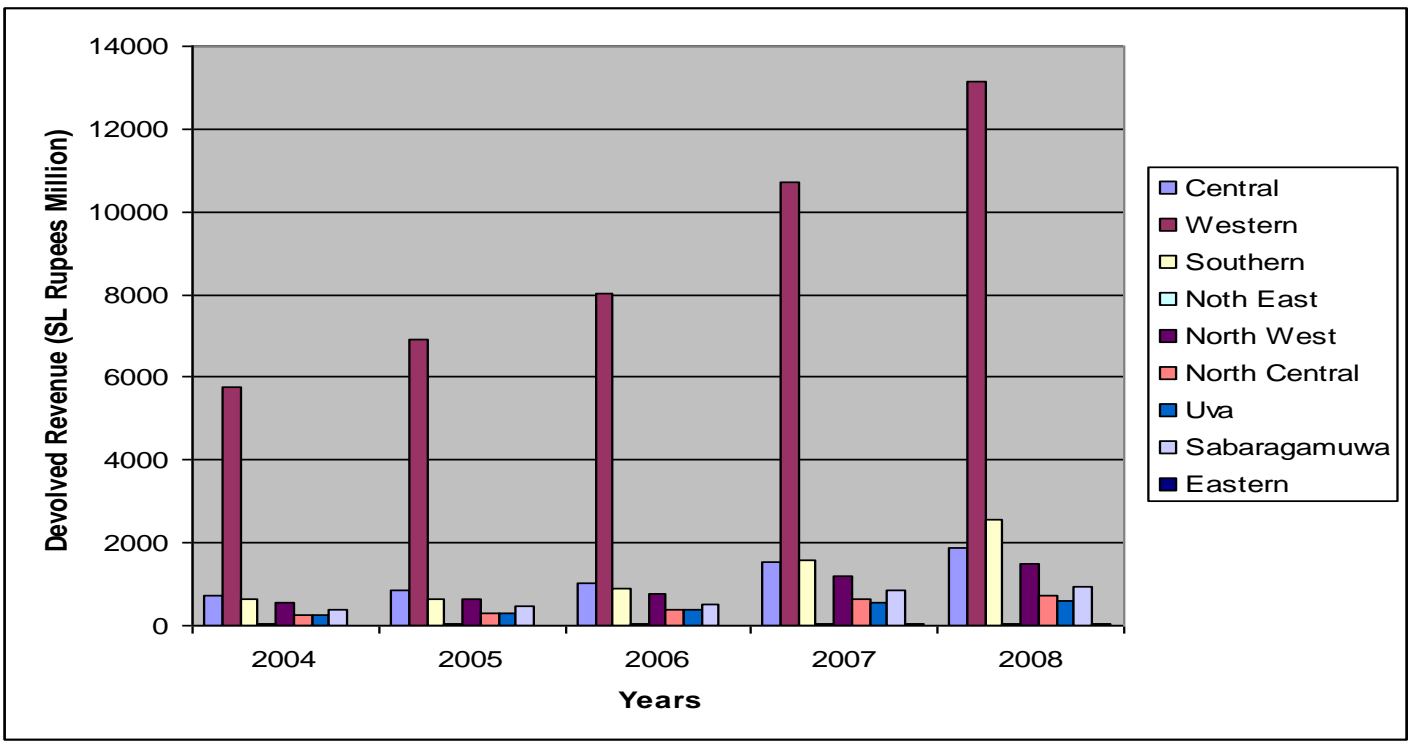

Note: Data on North and East accounts for 2004-2006; 2007 and 2008 account for Eastern PC Source: Ministry of Provincial Council and Local Government, 2009

Although the PCs are not allowed to negotiate directly with donors for foreign assistance, certain PCs get foreign funds with the help of central ministries for their development projects, for example, health and education (Gunawardena, n.d). Those initiatives are mainly based on the quality, ability, and the commitment of the leadership of the Province and the goodwill it enjoys with the government. However, at present rural road development projects implemented by PCs are funded by foreign aid.

Nevertheless, the divisional level takes on a new meaning and significance in the scheme of decentralised administration. From a public policy perspective, merely an administrative devolution will not be effective with limited fiscal decentralisation. Today the PCs suffer from inadequacy of financial resources due to limited financial decentralisation. The self-sufficiency of PCs was impossible, despite granting spending and revenue powers to PCs. Their own revenue accounts for less than $17 \%$ of their expenditures (ADB, 2004a). Therefore, they heavily depend on the centre. Table 2 shows the degree of decentralisation in SL which was $16 \%$ of total expenditure of government in 1990. This has substantially reduced thereafter. 
Table 2: Degree of Decentralisation 1990-2004

\begin{tabular}{|c|c|c|c|c|}
\hline Year & Revenue ratio 1 & Revenue ratio 2 & Expenditure ratio 1 & Expenditure ratio 2 \\
\hline 1990 & n.a & n.a & 13.5 & 16.3 \\
\hline 1991 & 13.7 & 2.5 & 8.7 & 10.7 \\
\hline 1992 & 13.9 & 2.7 & 9.8 & 12.1 \\
\hline 1993 & 13.5 & 2.7 & 9.7 & 12.6 \\
\hline 1994 & 14.2 & 2.6 & 9.6 & 12.6 \\
\hline 1995 & 13.4 & 3.0 & 8.3 & 11.1 \\
\hline 1996 & 13.8 & 3.1 & 8.5 & 11.5 \\
\hline 1997 & 12.2 & 2.8 & 8.6 & 11.7 \\
\hline 1998 & 15.1 & 3.2 & 7.8 & 10.2 \\
\hline 1999 & 14.5 & 3.4 & 8.6 & 11.2 \\
\hline 2000 & 17.6 & 3.4 & 8.2 & 10.6 \\
\hline 2001 & 15.7 & 1.8 & 8.2 & 10.6 \\
\hline 2002 & 16.1 & 3.3 & 7.5 & 8.9 \\
\hline 2003 & 16.0 & 3.8 & 7.4 & 8.6 \\
\hline 2004 & 17.4 & 4.0 & 8.3 & 10.2 \\
\hline
\end{tabular}

Notes: Revenue ratio 1: Ratio of provincial revenue to total government revenue

2: Ratio of revenue of all PCs less grant in aid to total government revenue

Expenditure ratio 1: Ratio of provincial expenditure to total government expenditure

2: Ratio of expenditure of all PCs to total government expenditure less defence and social security expenditure

Source: Ministry of Provincial Councils and Local Government and Central Bank of SL (as cited in Herath, 2006, p.14)

According to Herath (2006), as measured by expenditure, the degree of decentralisation in SL was well below that in both developed and developing countries. He points out that Argentina the share of state government expenditure in total government expenditure was $40 \%$ in 1987 and some developing countries similar to SL with unitary form of Government reported higher percentages than SL, for example, Poland (29\%), and South Africa (25\%).

The annual report of the Central Bank 2009 shows the budget expenditures and revenues of PCs as follows. 
Table 3: Budget Outturn for Provincial Councils (SLRs. Millions)

\begin{tabular}{|c|c|c|c|c|}
\hline Item & 2006 & 2007 & 2008 & $\begin{array}{l}2009 \\
\text { Provisional }\end{array}$ \\
\hline Total Revenue & 19,481 & 25868 & 31,368 & 29,433 \\
\hline Tax Revenue & 16586 & 21,473 & 25,992 & 24,907 \\
\hline Non-tax revenue & 2,895 & 4,395 & 5,376 & 4,526 \\
\hline Total expenditure & 94,470 & 113,067 & 120,011 & 130,260 \\
\hline Current expenditure & 76,428 & 92,721 & 103,199 & 111,336 \\
\hline $\mathrm{o} / \mathrm{w}$ personal emoluments & 60,497 & 74711 & 79,717 & 85,855 \\
\hline capital expenditure & 18,042 & 20,346 & 16,812 & 18,924 \\
\hline Central Government Transfers & 79,029 & 88,317 & 88,942 & 93,999 \\
\hline Block Grants ${ }^{19}$ & 62,342 & 70,742 & 76,773 & 77,386 \\
\hline Criteria Based Grants ${ }^{20}$ & 790 & 1,208 & 2,304 & 2,276 \\
\hline Matching Grants ${ }^{21}$ & 221 & 205 & - & - \\
\hline $\mathrm{PSDGs}^{22}$ & 7,345 & 6,995 & 7,262 & 10,945 \\
\hline $\begin{array}{l}\text { Foreign Grants for Special } \\
\text { Projects }\end{array}$ & 8,331 & 9,167 & 2,603 & 3,393 \\
\hline
\end{tabular}

Source: Central Bank, (2009, p.140)

According to Table 3, $82 \%$ of the PC's expenditures were from the central government. In 2009, the central government transfers to PCs increased by $6 \%$ to 94 billion. The total capital expenditure of PCs in 2009 was increased by $13 \%$.

During 2006-2009, the total government expenditures were SLRs. 713.6, 841.6 and 996.1 billion respectively (Budget, 2009). Accordingly, the total expenditures of the all PCs as percentages to total government expenditures were $13.6 \%$ in $2006,13.1 \%$ in 2007 and $12.4 \%$ in 2008. These figures further prove that the degree of decentralisation in SL is low as pointed out by Herath in the above section.

\section{Provincial Human Resources}

As with the provincial financing, provincial staffing is not without complexities because provincial cadres comprise of cadres of both the Combined Services and

\footnotetext{
${ }^{19}$ Block Grants are given to meet recurrent expenditures, e.g. salaries.

${ }^{20}$ Criteria Based Grant are given to meet capital expenditures based on certain criteria: the population; the per capita; the need of each province;

${ }^{21}$ Matching Grants is an award for good revenue collection. Such transfers were stopped from 2008.

${ }^{22}$ PSDGs: Province Specific Development Grant
} 
provincial appointees. The key positions in the provinces are held by the All Island Services (AIS) cadres. The Centre not only approves cadres for provincial ministries, departments, and other institutions in terms of structure, service delivery systems and positions but also determines the posting of officers of the respective AIS in core areas. The provincial authorities have no discretion in making any internal adjustments and deployment once cadres are approved (Gunawardena, n.d.). For many reasons junior AISs officers quite often occupy senior positions in the Provinces specially those of the DSs, despite the fact that the magnitude and complexity of responsibilities have grown over the years. The DS is a scheduled post for Class 1 of the SLAS, but out of 312 DSs only 110 officials are in that Grade (Ministry of Public Administration and Home Affairs, 2008). There were instances where those powers have been abused due to lack of hierarchical supervision or proper accountability arrangement, and posting of junior officials to such posts. The Ministry of Public Administration and Home Affairs sought Cabinet approval to amend the Act in $2006^{23}$ with a view to empower the GAs to entertain appellant jurisdictions against decisions of the DSs. This matter has not been resolved as yet.

In regards to the provincial staff, however, the Governor of the Province has the authority to determine appointments, transfers, dismissals and disciplinary control, which are delegated to the PPSC. The provincial public service has not been covered under the $17^{\text {th }}$ Amendment to the Constitution, which created the independent NPSC. The PPSC is appointed by the Governor, so that any political decision in regard to personnel management of the provincial staff can be taken, as discussed in Chapter 3 . The Treasury can control appointments of provincial staff by controlling the budgetary allocations; otherwise the Governor has full control and authority.

V.K.Nanayakkara, former Secretary to the Ministry of Education mentioned that,

There were instances where after 60 years of age we have to re-employ some people, like Tamil, Aesthetic and English teachers because those teachers are scarce. If we want to re-employ the officers after 60 years of age we have to get the approval from the NPSC. The NPSC never approves such re-employment. So, we couldn't get the approval from the NPSC for a particular appointment. But the interesting thing was that the same request was made to the Western PPSC and got the approval. Even today all PPSCs are under the governors and they can take any political decisions (Interview, 06.11.2007)).

\footnotetext{
${ }^{23}$ Cabinet Memorandum dated 27.03.2006 on "Strengthening the District Administration to cater to the needs of the government development programme"
} 
Similarly, the provincial staffing and inter-provincial transfers are matters of concern. There were instances where new appointments (teachers and health professionals) have been made to provinces by the line ministries without any consultations. Further, some developed provinces have excess staff and less developed provinces have shortages; for example, significant excess cadre over the approved number of teachers in the Southern and Central Provinces. Inter-provincial staff transfers have led to this situation. In order to effect inter-provincial transfers, one has to obtain the concurrence from both provinces, which creates problems for some individuals who do not have political or bureaucratic back-up. The procedure for inter-provincial staff transfers is thus complicated and time consuming. This led to corruption and malpractices. There is a need to rationalise cadres in each province, if PCs are going to operate more effectively in the future. At present, total number of provincial cadre is 293,416 (Ministry of Finance and Planning, 2009).

Other problems in the Provinces are limited opportunities for positions for AIS cadres and lack of other facilities.

Dr. B.S. Wijeweera, former GA in an interview responded,

Avenues available in the provinces are little. The GAs and provincial secretaries are in the provinces. Nothing compared to what is available in Colombo; all the top jobs, all ministries and departments are in Colombo. Provincial Secretaries are few.

He further said,

The most important thing we have to think about is infrastructure, for the benefit of public servants, for instance, schools. One of the most important things in the mind of the public servant is how to give good education to his children. All the good schools, except a few, are located in Colombo [and the main cities]. In every district, if you have a top quality central school, having all the facilities (the teachers and equipment that you have in the best Colombo schools), that will encourage the public servants to work in the provinces. The education system of the country also should be changed along with this (Interview, 09.01.2008).

Accordingly, the arrangements in the staffing in provinces clearly show that there are negative implications in the country's public personnel management system.

\section{Legislative Powers}

The $13^{\text {th }}$ Amendment gives legislative powers to the PCs to pass statutes with regard to subjects that are listed in the Provincial List, and the Concurrent List in 
consultation with Parliament. These statutes give legal authority to PCs to exercise executive powers that are vested in the Centre on the basis of existing laws; thus, they are necessary preconditions for the province to step in to derive executive authority. However, the PCs are facing problems of exercising this legislative authority at present due to three reasons: the ambiguity in interpreting the three Lists, lack of capabilities in the provincial staff in drafting statutes, and poor access to central legal authorities in getting advice (Gunawardena, n.d).

There is an ambiguity in interpreting subjects in the List I (those devolved to the PCs) and List III (those concurrently managed by the centre and the province). This creates a major bottleneck in making statutes by the Provinces because there is no uniformity in defining and describing the subjects. This ambiguity of defining subjects was highlighted by the Attorney General in his undated letter to Secretary Ministry of Public Administration, Provincial Councils and Home Affairs, in relation to the Agrarian (Amendment) Bill. The second paragraph of the letter says,

Agriculture and Agrarian Services are two matters set out in the Provincial Council list of the ninth schedule. An examination of the ninth schedule indicates that matters devolved are those that are expressly stated in List I or List III. As stated in the Supreme Court special determination No. 2 and 4 of 1991 the headings in List I and III are not comprehensive or all inclusive. The Court has held that it is not possible to determine whether a matter is a List I or List III subject by merely looking at the headings of those Lists. ....the ambit matters to be included or excluded in terms of the ninth schedule should not be determined in the abstract but by consideration of the nature and scope of each individual item (Committee to Study the Operation of Provincial Councils, 1996, Annexure 4).

Therefore, it is necessary to study the scope of each individual item when PCs make statutes to ensure the content of the statute is within the scope of the Listing and refers the same matter. Hence, Statute making is a complex task in the PCS which needs such skills in legal drafting.

Furthermore, statute making is hindered by the Province due to the non-existence of legal advisory bodies in the province and lack of access to Legal Draftsmen's Department or the AG's Department since they are Central Government Organisations. PCs face acute snags in obtaining legal advice on the constitutionality of statutes. Accordingly, due to lack of legal environment "PCs have failed to pass statutes that would vest themselves with powers to take executive actions in respect 
of key devolved subjects" (Gunawardena, n.d, p. 50) but 40\% of statutes passed are in categories of finance and administration which provide for day-to-day housekeeping matters. This situation is further aggravated by incapacity and reluctance to challenge the central authorities by the provincial authorities due to their political relations and concern for personal survival.

In the absence of necessary statutes by the Provinces, the central government has taken back some of the schools and hospitals which were formerly devolved to the PCs.

Dr. H.A.P. Abeywardene, former GA, commented,

If you are giving more power there is a possibility of a threat to the central government. Therefore, the centre did not give full authority to the PCs. In effect what happened was the PCs were not given all the powers, education, and police. The centre is pulling even the powers given. In education sector, schools are made national schools, overnight without the knowledge of the people in the area till the board is declared opened, even the MP in the area doesn't know. Hospitals are made national hospitals, Matara, Kegalle, Rathnapura overnight without consultation and valid reasons. What they should have done was to strengthen these institutions, give resources, staff and see how they are faring with their performance. Government is playing a safety device (Interview, 22.12. 2007).

The above discussion clearly highlights the issues in relation to legislative functions in the Provinces due to lack of clarity in devolved functions. In fact, these issues have direct negative implications for public management, thus needing immediate attention.

\section{Coordination Issues}

The lack of a constitutional or administrative mechanism to coordinate between the government and the PCs as well as between provinces is a major bottleneck in the present system. In such a lacuna, interpersonal and administrative relationships depend on informal political and administrative personal relationships.

The Report of the Committee to Study the Operation of the PCs in SL (1996) has indicated several shortfalls in coordination at the top level, intra-provincial and interprovincial level. I interviewed two of the five Committee members during the field 
work. They mentioned that most of the issues they highlighted in their report remain unresolved. These are highlighted below.

\section{At the Top Level}

There is no regular institutional forum to discuss crucial matters that should be dealt with by the highest officials such as President and the Chief Minister, President and the Governor, and the government ministries and the PCs. As such, firstly, the Bills relating to devolved subjects are sometimes introduced in Parliament without consulting the PCs (Committee to Study the Operation of Provincial Councils, 1996). Secondly, the central government decides an increase of salaries and allowances for certain cadres without the knowledge of the PCs which aggregate financial problems in the PCS. Lastly, there are staff transfers by the central ministries without consulting the relevant provincial ministries (Gunawardena, n.d).

Due to the lack of coordination between the Centre and Province, there are several ambiguities in some of devolved tasks. This leads to conflict between the Centre and the Province and also the non-compliance of national policies by the Provinces.

In an interview, Vijitha Herath, MP, JVP, said,

The policy of one subject is different from province to province and sometimes does not comply with the National policy; for example, the Education Policy of the Central Ministry of Education regarding the issue of new text books to school children. If a Province wants to introduce new text books it should be under the authority of the Secretary of the Central Ministry of Education. Nevertheless, the North Central Provincial Secretary of Education gave authority to introduce a new text book which is recommended by the NGO called Pan Sri Lanka. The school teachers were given training in this respect by that NGO. This book was not recommended by the National Institute of Education.

Another good example is regarding environmental policy. There is a National Environmental policy and a Central Environmental Authority in the centre. Some PCs have their own statutes for environmental matters, for example, the Wayamba PC [North Western] has a statute on the environment. According to that statute the PC is not accountable to the Central Environmental Authority. There was an environmental problem in Chilaw area due to the digging of clay. The Provincial Environmental authority has issued permits for digging clay while the Central Environmental Authority took a decision to stop people doing so. The police were helpless because the people who engaged in the digging were issued with permits by the PC. When the Central Environmental Authority sent a letter asking officials to be present to discuss the particular matter, they replied that they were not going to be present because they are not accountable to that Authority. The people of the area were not bothered whether it is PC matter or a Central Government matter, to them, the digging of clay is an environmental 
problem. This happened during the regime of UNP, both the PC and the Central Government were ruled by them. Ultimately, the PC officials were summoned to

Parliament to discuss the matter entirely on an amicable basis (Interview, 18.01.2008).

He went on to say that there are a lot of other examples where central government and the PCs are having clashes. These problems are inevitable when there are two parallel systems without proper demarcation of functions and their coordination.

\section{Intra-Provincial Level}

There were and still are coordination issues due to the non-integration of District Secretaries, Divisional Secretaries and Grama Niladaries into the PC system. As mentioned above there are two parallel systems running through the service delivery: PCs through the provincial ministries and departments, and the Central Government through the District Secretaries, Divisional Secretaries and Grama Niladaries (Appendix 6).

Capital investments in the Provinces are politically driven without a coherent plan or coordination. For example, each MP gets SLRs. 5 million (2008) annually from the Decentralised Capital Budget (see Chapter 5 for detail). This budget allows the MPs to determine development activities in which they are personally interested in their respective electorate. The Provincial Councillors also exercise similar influence in the prioritising of provincial capital investment. At the Divisional level the members of the Local Government make decisions in regard to small-scale capital works in areas of their individual interests. Thus, the national and provincial planning is poorly coordinated. This results in an unbalanced development within the country and also has a divisive effect on the people which clearly have negative implications on the country's public administration.

\section{Inter-Provincial Coordination}

Provincial service deliveries are further hampered due to the lack of institutional arrangements for matters between provinces. In certain instances the lack of interprovincial coordination led to delays in service deliveries as well as causing disputes 
and wasting of resources, for example, the sharing of irrigation and river waters, and the inter-provincial road and communications (Gunawardena, n.d).

In summation, at present the government machinery for public administration has extended to almost every activity within the society. As a result the government organisations have increased enormously and their structure and the process of service delivery have become complex and diverse. Due to the lack of proper coordination of functions at three levels, a lot of problems encountered for the last two decades have led to negative implications and complexities in the public administration.

\section{Parallel Pre-devolution Institutional Arrangements}

In addition to the coordination issues, there are other issues in relation to the institutional arrangements in public administration due to use of central service delivery structures in most goods and service deliveries in the Provinces. Their scope and content of activities are largely determined by the respective central government ministries; for example, the Divisional Secretariats (Chapter 3), Zonal Offices in Education, District and Divisional Planning Secretariats and Health institutions. The heads of these institutions are central government appointees. Despite 'provincial planning' being a devolved function, the district and divisional planning secretariats of the central government have been strengthened (Gunawardena, n.d). As such, predevolutionary systems in the Provinces have further deconcentrated the provincial administration (Gunawardena, n.d; Wanasinghe, 2005). Thus, Gunawardena argues that because the provincial service delivery structures have been created by the Central Government as "National Policy" and adopted by the Provinces by staffing them through cadres released to the Provinces from respective AISs, there can be no provincial responsibility or accountability in such a system.

Since development functions of the PCs have been carried out through the DSs, the administrative authority of the Provincial Ministries tends to be ignored in practice. Furthermore, the Grama Niladari, who is the general service officer at the village level and also a central government officer, comes under the Ministry of Home Affairs. He usually works under the supervision of the DS. The system remains the 
same, before and after the devolution, in carrying out services to the public. All these aspects are remarkable impediments to provincial autonomy, and thus create negative implications for the country's public administration.

\section{Overlapping/Duplication and Irrational Grouping of Subjects}

Furthermore, due to the reluctance to rationalise and restructure institutional arrangements at the centre, there is considerable vertical and horizontal overlapping and duplication of institutional structures and functions at the three levels (Wanasinghe, 2005): the centre, province and local. This is most evident in the proliferation of ministries and attendant institutional structures at the centre. In the devolved environment in 2008, there were 57 Cabinet Ministers, 35 non-Cabinet Ministers and 15 Deputy Ministers at the centre, making it the largest Cabinet in the world in the $21^{\text {st }}$ century (Appendix 1), plus 40 ministries in the Provinces. India, with a population of over 1 billion and many times bigger than SL, only has 45 ministries. China, which also has around 1.3 billion people, had 45 ministries in 1983, 41 in 1993, and 28 in 2003 (Uswatta-arachchi, 2008).

The main reason for proliferation of large number of ministries at the centre is that, as discussed in Chapter 3, the President is vested with powers to determine the numbers of ministers in the Central Government, unlike the PC system. In the Provinces the number of ministers for each $\mathrm{PC}$ is restricted to five, including the Chief Minister, by the $13^{\text {th }}$ Amendment to the Constitution. This discipline is lacking in the Centre.

In the Government Gazette No.1482/9 dated January 29, 2007 which contained the subjects and functions of government ministries, there were critical lacunae in defining functions and allocating tasks under devolved polity. Some ministries do not have clear mandates while others did not have adequate tasks to perform, for example, the Minister of Special Projects, and Minister of Youth Empowerment and Socio-Economic Development. The only task assigned to the Minister of Special Projects was "Assisting other ministers in the implementation of Special Projects". There are in fact two ministers for youth: (a) Minister of Youth Affairs and (b) Minister of Youth Empowerment and Socio Economic Development. The Ministry 
of Plantation Industries which hitherto dealt with roles relating to tea, rubber, coconut, sugar, palmyrah, cashew, and state plantations has been broken into three ministries: Ministry of Supplementary Plantation Crops Development, Ministry of Plantation Industries, and Ministry of Public Estate Management and Development. Most of the institutions coming under the Minister of Supplementary Plantation Crops Development have been defunct industries for more than a decade, for example, Kantale and Higurana Sugar Industries Ltd. The Higurana Sugar Industries was earmarked for sale in 2005 by the Public Enterprises Reform Commission due to non-availability of financial resources to restart operations. Approximately eight million rupees are spent annually on maintenance of its assets and the staff without any production (Budget, 2008, 2009). These are matters for future reforms.

The confusion over ministerial responsibilities is evident at recent Cabinet meetings. A cabinet paper presented by the Minister of Irrigation and Water Management on July 4, 2008 to market water was challenged by the Minister of Agricultural Development and Agrarian Services, who presented a cabinet paper No.55/2008 stating that water management affairs come under the purview of his ministry ("Sirisena squabbles with Chamal", 2008).

The allocation of roles is further complicated in the way they have been undertaken. For example, 'disaster management' is performed by one ministry and 'disaster relief services' are performed by another ministry at the centre. The rationale might be decoupling of policy and service delivery. If so, disaster relief services should be handled by the provinces where disasters occur. Furthermore, Social Service is a devolved subject as well as a concurrent subject. There is a separate cabinet minister for 'social services and social welfare' at the Centre. On the one hand, disaster relief services are also a type of social service under the Provincial List. Each PC has its own ministries for social services. In this manner the roles and functions of the Centre and the Province are not clear enough but overlap, wasting scarce resources.

Furthermore, the proliferation of ministries not only duplicates functions but also is an extravagance and a major obstruction to effective devolution. The expansion of the public services, vertically and horizontally, virtually is beyond control under this political culture. The number of ministries continuously has been expanded from 
2005 with the crossing over of the MPs from the Opposition to the Government. This situation led to fragmentation of functions of the existing ministries. They have become a burden to the Treasury which has to finance ${ }^{24}$ them.

\section{V.K. Nanayakkara, former Secretary, Ministry of Education, said}

We have 100 odd ministries from 2005, for example, in 2005 fertilizer imports were handled by one ministry, Ministry of Agriculture, and the distribution was handled by another ministry, the Agrarian Service Ministry. Same with education and plantations. How many ministries are there for Plantations now? Sugar cane, cashew, palmyrah is allocated to one ministry; tea, rubber and coconut is handled by another ministry, state plantations by another. How can the country progress? How can one coordinate 100 ministries and make cohesive work? Each ministry is independent (Interview, 06.11.2008).

Professor S.W. Ranasinghe expressed his view on the large Cabinet,

We have the largest cabinet in the world. The legislature has 225 members, among them 108 are executives. It has changed the mechanism. The members of the legislature should be bigger than the executive. The members of the executive should be small in number. But here the executive is half as big as the legislature. They didn't see the logic of that. There was a high level of fragmentation of functions. There are several ministers for one function. For example; agriculture and plantation, there are several ministers; they are riding on the people. All that's happened due to poor governance.

He further said,

Now people look at ministers sarcastically. The politicians are like commodities. They can be purchased. Some ministers do not have work. But they have offices on exorbitant rent with 4 or 5 employees. There are no properly defined functions. Anybody who jumped across is given a ministry. A MP can become a minister easily when he crosses over to the government. Secretaries are losing credibility. The concept of ministers is diluted. The executive is losing their credibility. People do not take them seriously. This is a kind of political game. This is very serious. Anyone can go to the Courts and challenge decisions of the government because their subject matters are not clearly defined. There are lots of duplication of work. In the plantation sector there are so many ministers. It is a joke (Interview, 11.12.2007).

The Editorial of the Island newspaper (2007, December 26) illustrates that,

The people have begun divisively calling Parliamentarians 'Kotipahe Kaeli'- pieces worth 50 million Rupees- the worst that can happen to democracy. The people lose faith in public institution like national legislature. Crossover led to the deterioration of the people's verdict at election. In the present parliament some of the politicians the people wanted to keep in the opposition are in the government as ministers and those whom they voted to power are in the Opposition. There are already 24 UNP MPs' in the Government

\footnotetext{
${ }^{24}$ Rentals for office spaces, housing (SLRs 100,000 per month for individual minister who are not provided a government bungalow), personal staff and their perks, vehicles, fuel allowances, postal and telecommunications (unlimited), extra security personnel and vehicles for back-up security (more than five vehicles and security people per head depends on the needs).
} 
and about 40 ruling party (UPFA) MPs' in the Oppositions. It is ... feared that before long there will be a government of Ministers!

V.K. Nanayakkara, former Secretary to the Ministry of Education, in an interview said,

We have governments that are dependent on coalition partners due to the electoral system. You cannot expect a lean cabinet under this situation (Interview, 06.11.2008).

In this sense, there is a problem in the electoral system in SL too, which leads to unstable coalition governments with the switching over from the First-Past-the Post (FPP) electoral system to a more competitive Proportional Represent (PR) system by the 1978 Constitution. A Parliamentary Select Committee has been appointed and proposed some changes to existing PR system to remedy the situation, but even under the FPP system it has been shown there had been weak governments and crossovers (Island, 2007, December 26). In the past, however, the crossovers were not necessarily offered with ministerial portfolios like today.

However, the proliferation of ministries is welcomed by the politicians and the bureaucrats because they can enjoy privileges at the expense of the general public. The bureaucrats, especially the Class I officers of the AISs, have many opportunities for promotions: Secretaries, Additional Secretaries, Senior Assistant Secretaries, and Directors. According to K.H.J. Wijayadasa, former Secretary to the Prime Minister and the President (1984-94), "We spend lots of the money for the provision of perks of politicians and bureaucrats, nothing else. We cannot find funds for development, erecting bridges, and hospitals" (Interview, 10.12.2007).

In addition to proliferation of Ministries, there has been a trend to increase the numbers of departments and agencies in ministries too, further fragmenting core functions. As the public choice theory claims, bureaucrats tend to enlarge their territory, budget and patronage. For example, the Treasury had eight departments (in house) in 2002; now it has gained five more departments by breaking down the core functions of the existing departments, adding legal affairs and upgrading the Internal Audit Unit (2008). The major underpinning of these developments might be to satisfy Class 1 officers of AISs to avoid any resistance when accommodating outsiders (favourites) for high positions on patronage rather than a necessity. Some 
departments have only 10-15 employees with a Director General at the top. Each department has its own administrative and account division which wastes public funds.

\subsubsection{Service Delivery Problems}

Over time, SL governments retained the monopolistic role in the delivery of public goods and services that are essential for the people's daily life. This includes education, health care, a remarkable portion of bus transport and total ownership of rail transport, infrastructure facilities such as power, water, highways and roads, and consumer services and agricultural marketing. Education and healthcare are provided free of charge. The rail services are on subsidy. Although the government gives high priority in service delivery, it is also evident that "the quality of goods and services in terms of access, equity, efficiency and sustainability has progressively deteriorated" (ADB, 2004b, p. 15). This situation led to erosion of public faith and "particularly given the prospect of the potential for social unrest" (ADB, 2004b, p. 15). There is lack of transparency and access to information for citizens in service delivery. The citizens do not have access to information about individual responsibility of public officials for service delivery. The Official Secret Act No.32 of 1955 also paves the way for lack of transparency and openness, which are added to by the bureaucratic culture. Citizens' organisations are also inadequate to initiate campaigns for securing their rights and to arrest this situation without political initiatives.

Kannangara (2008) was very critical of the country's education system and ineffective management, which failed to provide adequate teachers to rural schools and provide school text books in time to the students while the Ministry of Education had three political leaders at the top, a Cabinet Minister, a non-Cabinet Minister, and a Deputy Minister.

Dr. H.A.P. Abeywardene, former GA, commented on the present situation of the service delivery system,

There is no transparency. It is lacking. The service delivery is weak because of the corrupt practices that have crept into public administration (Interview, 22.122007 ). 
Dr. Lloyd Fernando, Former State Secretary for the State Ministry of Policy Planning and Implementation (1989-1993) elaborated,

In the modern state, the public service has to perform fundamentally two inter-related functions - service delivery and development promotion. Service delivery covers, issuing of licenses and permits, registering of property and the performance of similar regulatory functions. The development function is more complex. It involves promotion of economic growth, employment creation and price stability through the private sector and where necessary through public investment. The performance of the public service in SL has been declining in respect of all the above functions for at least more than two decades. At the end of each financial year, we see funds allocated for projects being returned to the Treasury due to shortfalls in implementation. Even where funds have been fully utilised, there is very little impact assessment. Even though the Ministry of Plan Implementation has established a very elaborative progress monitoring and post-evaluating system, its effectiveness is low, due to weak monitoring by the implementing agencies and ministries concerned. One of the major reasons for this situation is the lack of leadership provided by the ministry secretaries, themselves. They are preoccupied with routine administrative functions which could be delegated to subordinate staff. Similarly they spend a large amount of time at meetings, both internally and at external venues, which are often unproductive and could be dispensed with (Interview, 06.01. 2008).

The issues identified in this section have significant implications for the country's public administration.

\subsubsection{Implications for Public Administration}

According to Wanasinghe (2005), exercises in regard to institutional arrangements have so far tended to ignore the local community level. Even though the actual delivery of public goods and services should occur at the local level, whatever powers have been devolved, so far it has been clogged at the Provincial level. In that background, he argues that local people have almost no participation in the decisionmaking, or the activity of delivery of goods and services. Rather this reflects the continuing strong influence of the politico-administrative culture of a centrally controlled and administered economy.

The overlapping and duplication, both vertical and horizontal, have contributed to delays, corruptions, malpractices, confusions and coordination problems, and bottlenecks in the flow of public business (Gunawardane, n.d, Institute of Professional Public Administrators, 2007). 
Citizens are in a desperate situation when they have a problem, as to whether they should go to the central government institution, PC or local government body to settle it. This situation was highlighted by Lionel Fernando, Co-Chair of the Salaries Commission, in an interview:

Things are very difficult to the people yet. They do not know where to go. When there is electricity failure whether you go to the Pradeshiya Sabah, or Electricity Board or PC. The power through devolution is not implemented for the wellbeing of the citizens. I am in trouble sometimes. When I have a problem I do not know actually where I should go. Recently, just a week ago, I had a problem. They asked me to go to Pradeshiya Sabha. I asked whether I have to go to Kotte PS. somebody told 'no', you should go to Kaduwela. Somebody else told that it is not in Kaduwela now it is in Malabe. So you are in trouble. Those days we knew when you did not receive letters to whom you should go. Now we do not know where to go, Kotte, Malabe or Kaduwela. The functions are not clear enough (Interview, 06.01. 2008).

This shows that the information available to citizens on the details of the public services that are provided, on the level of performance in the delivery of such services, on the processes of decision-making in regard to the planning of such provision, are inadequate. Division of powers, roles and responsibilities between central ministries, PC and District Secretaries/GA and DSs has been a subject of conflict. According to Vijitha Herath, MP, JVP, "the overlapping of roles and responsibilities between central and provincial departments of the administration has resulted in wastage of scarce resources and misuse of authority by the political and administrative executives to a substantial level" (Interview, 18.01 2008). The AG's Report 2008 (pp 161-162) highlighted several deficiencies in the PC system. Information required vouching transactions valued at SLRs. 650.75 million relating to 14 institutions of the PCs had not been furnished for audit; replies to 834 audit queries in respect of the year and the preceding years had not been furnished (the value of quantifiable transactions relating to those audit queries amounted to SLRs. 460.77 million); and 569 transactions valued at SLRs. 381 million were either fraudulent, uneconomic, unauthorised or irregular. Thus, citizens' expectations and the capacity of service delivery by the government has a large gap.

To sum up, the present administrative structure of SL reflects many deficiencies due to lack of top level coordination, cohesive national policies, and clear demarcation of roles and responsibilities. The information provided on the PCs show that their existence is not without problems. The main objective of setting-up the PC was to 
solve ethnic conflict in the country, but this has become a myth without real political, administrative and economic devolution. The North-East PC ceased to operate from the very beginning, and the conflict since then changed from ethnic strife to nationwide armed struggle with intensive violence from 1983 to 19 May 2009 (the government defeated the LTTE on 19 May 2010). However, the devolution is still a desirable goal for SL in order to address Tamil interests, even though the LTTE war is over.

\subsubsection{Supreme Court (SC) Intervention}

Another aspect which this study will discuss is the increased intervention of SC in matters relating to public administration. The $\mathrm{SC}$ in the recent past gave landmark rulings on several matters due to failure of the relevant administrative authorities.

Dr. H.A.P. Abeywardene, former GA, commented,

For the slightest provocation people go to Supreme Court. Now SC is going far away from their normal work. Even for school admission. This shows to what extent the administration has broken down (Interview, 22.12.2007).

The following examples elaborate on this situation. 


\section{Box 1: Grade 1 School Admission for the year 2008}

The Grade 1 school admission in SL has become an annual public policy fiasco (Samarasinhge, 2008). The process of selection led to many irregularities, malpractices and corruptions each year due to competition of parents to enrol their children in to so called 'national schools'. SL has 9,714 government schools, out of which 324 are national schools, island wide, and with better facilities than other schools governed by the central government (Ministry of Education, 2009). Due to this structural problem in the education system, the demands for admission to these schools are always higher than that of the supply. It is a popular secret that some parents who are not residing close to these schools can still enrol their children by forwarding false documents. In some instances children who reside near such schools are not selected for enrolment. The parents whose children were not selected for 2008 enrolment and reside near schools have sought the SC intervention. Having considered the policy framework of selection, the SC pointed out that existing quota system for children of military and police personnel is inconsistent with constitutional provisions. Then the SC ordered the Secretary to the Ministry of Education to revise the policy framework and issue a new circular according to the guidelines set by the SC (SC No.289/2007). 


\section{Box 2: Teachers' Salary Anomaly}

Another occasion where the SC had to intervene in the public administration was on the matter of the "teachers' salary anomaly". The evaluation of answer papers for the General Certificate of Education (Advanced Level) examination held in August, 2008 was delayed due to the teachers' boycott. Their main demand was to remove the long-standing salary anomalies. Eventually, the teachers sought $\mathrm{SC}$ intervention due to the failure of the proper authorities to solve the problem. In principle, the SC recognised that there is a salary anomaly with regard to the Teachers' Service and directed the Salaries and Cadre Commission to place the teachers' salary on the proper scale. Then, the SC as an interim relief ordered the Education Ministry to pay the teachers a salary increment immediately until the teachers were placed on proper salary scales and requested the respondent teachers' unions to commence Advanced Level paper marking (Ramanayake, 2008).

Ironically, SL has maintained Salaries Commissions since Independence with the specific objective of revising salaries and allowances of government employees. They are Poulier Commission (1953), Wilmot Perera Commission (1961), L.B. de Silva Commission (1974), B.C. Perera Commission (1995), Tissa Devendra Commission (2000), and Salaries and Cadre Commission (2007) (Devendra, 2008). 


\section{Box 3: Health Sector Strike}

Health sector strike was scheduled in mid 2007 by health sector trade unions against the introduction of the "finger print machine" to mark attendance.

In this case the SC banned the strike, considering the fundamental right violation application submitted by a patient. According to the Daily Mirror Editorial ("Reforming the Public Service," 2007, p. 8),

The introduction of this method has now given rise to much controversy and conflict at certain government departments. The controversy continues to persist in the health sector where the system is now operating. Having first introduced it to 14 institutions under the Health Ministry the authorities have extended it to all state hospitals. In protest against this system, the hospital employees unions have decided to come out today and tomorrow. Their rejection is that the authorities have exempted certain sections in the health sector from the scheme. This, they view, as an act of discrimination.

The new system meanwhile has yielded good results. Employees' attendance has improved and overtime bill has been reduced by 30 percent, according to the authorities. The ministry authorities have quite rightly insisted on the full implementation of the scheme and asserted that the system will not be withdrawn under pressure.

In sum, public sector involvement in the economy has increased over the years after Independence (1948) and retained the monopolistic role in the delivery of public goods and services that are essential for the people's daily life. Nevertheless, the quality of service delivery in terms of access (e.g. public hospitals), equality (e.g. education), timeliness (e.g. transport), and affordability (e.g. gas, electricity) has been overlooked over time, thus public dissatisfaction and erosion of faith of the government institutions have increased simultaneously. For example, some of the public institutions have failed to solve even simple problems in the recent past such as enrolment of school children to year 1. At the breakdown of the normal channel people tended to seek the SC intervention to settle their problems. Hence, the current process of delivery of public goods and services needs urgent attention in any future agenda of reforms.

However, there are few signs of improvement. The following section discusses them. 


\subsubsection{Positive Aspects of Public Administration}

\subsubsection{Productivity Improvement}

One of the positive attempts taken so far to improve efficiency and the productivity in the public service was the introduction of productivity improvement programme in the public sector. SL obtained the membership of the Asian Productivity Organisation (APO) based in Japan in 1966. However, until 1994 this initiative had not been used properly due to lack of attention and leadership. After a lapse of many years, in 1994 the then Minister of Industrial Development of the SLFP-led government took initiatives to launch a productivity improvement programme in the public sector. However, that initiative did not move forward adequately because the minister was killed in a 2002 bomb explosion. In 2003 the UNP-led government gave prominence to productivity improvement in the public sector and reactivated the National Productivity Secretariat (NPS) under the Ministry of Employment and Labour.

The Ministry of Employment and Labour developed a National Productivity ${ }^{25}$ Policy for SL, aiming to achieve accelerated growth in the economy. This policy has two components: the private sector and the public sector. Under this policy, it is expected to achieve 5\% annual growth of productivity for the nation. In order to achieve these targets, this Ministry took steps to formulate strategies and action plans. The NPS of the ministry is functioning as the catalyst in this endeavour.

The NPS attempts to inculcate an awareness of productivity enhancement and to cultivate a productivity culture in the nation, mainly through four programmes: productivity at schools, public sector, private sector, and the community. The NPS uses various methodologies to disseminate knowledge on productivity and make every citizen aware of productivity concepts (National Productivity Secretariat, 2005). These include: organising training programmes, delivering lectures, and

\footnotetext{
${ }^{25}$ Productivity is defined as the effective and efficient use of resources to achieve desired outcomes. Effectiveness refers to the level of outputs or outcomes from a process, job or an organisation's effort. Outputs refer to immediate results, and outcomes are related to long-terms goals or long term consequences of outputs. Efficiency refers to the ratio of outputs to inputs (Ministry of Employment and Labour, n.d).
} 
conducting workshops and seminars. It also organises competitions and awards the best people and organisations that participated in the innovation for showing the ways to greater productivity. The NPS obtains the assistance of local and foreign expertise in promoting a culture of productivity. It realises the importance of raising the awareness of school children as a long-term strategy to improve productivity, so the NPS closely works with the Ministry of Education to realise this. According to the Director, NPS, "around 500 school programmes have been successfully conducted each year and the students' participation in productivity competitions are great. There are several 'productivity model schools, offices and work places' throughout the country, including both public and private organisations". The NPS has established a "Best Practices Network" comprising all winners of the productivity competition. It organises a monthly meeting to share their experiences with others who are interested in improving productivity in their organisations. The NPS also organises study tours to those model offices and work places to motivate others in the productivity improvement programme.

In an interview, Director of NPS said,

We try to change the work attitudes of the people. We want to have behavioural changes in an incremental manner but the impact is wide. We give this message to the whole country through media, and video campaign. We were able to make some progress in some government institutions to increase customer satisfaction, reduce waiting time in service delivery and giving information to public through this movement (Interview, 27.12.2007).

Accordingly, the NPS is focusing more on the human aspect of productivity rather than technologically-driven process improvements. Once awareness is made, other aspects can be easily adopted to the administrative apparatus in the country because bureaucratic changes are not easy in SL.

\subsubsection{E-Government Project}

The other attempt to increase efficiency and effectiveness of the public service delivery was the introduction of E-Government project. E-Government has become an important policy agenda for governments around the world with key transformational objectives such as public service transformation, transformed public engagement and establishing citizen-focused government (Lips, 2008). SL also 
recognised the importance of the E-Government initiatives in 2002 and established the Information and Communication Technology Agency (ICTA) under the Information and Communication Technology Act of 2003. It attempts to introduce ICT in the delivery of public services while redesigning the ongoing delivery processes in order to make government business more citizen-focused and friendly, and avoid delays and malpractices that have crept into the service delivery process over the years. Accordingly, this project expects transformation of major aspects in public management and sustainable improvements in efficiency, openness, effectiveness, and quality of services (ICTA, 2009). The E-Government project is at the infant stage. It provides a base for future reforms.

However, the ICT literacy levels and personal computer penetration within the government and the society is extremely low. The ARC (1986/88) noted that public awareness regarding the impact of IT has been limited, so a concerted attempt would need to be made to make the end users computer literate. Therefore, an attempt has been made to create an enabling environment in government and society by installing IT infrastructure in the government institutions, and the community organisations in villages in the first phase of this programme. Accordingly, by 2007 , the majority of government institutions, including the district and divisional secretariats, were supplied with IT infrastructure and connectivity in parallel with providing key citizen and government services using ICT. Around 500 "Nanasala" (knowledge centre) were established with internet, email, telephone facilities throughout the country, and computer training was given to citizens in the use of internet and email and to share knowledge without much cost to them. The building up of the institutional capacity and the skills of the public officials are paramount to managing the process, and to achieving E-Government objectives.

Accordingly, some of the service delivery has been already improved over the last few years; for example, issuance of passports, visas, birth certificates, motor vehicle revenue licences and provision of airport and bank services, and some government information. The Department of Immigration and Emigration has made considerable progress in transformation of procedures and processes in keeping with the international standards of issuance of passports, visas and provision of airport services (National Council for Administration, 2006). At present anyone can get a 
passport within a day with an additional fee. In addition, a motor vehicle revenue licence can be obtained in two minutes in Colombo and a copy of a birth certificate can be obtained in 10 minutes. The state banks also have modernised their transaction processes by using ICT (ICTA, 2007). The Government Information Project won the international award for excellence in Singapore in 2006. These are great achievements in the public sector service delivery when compared with the situation earlier when it took a long time to provide these services even with bribes. The SL Institute of Development Administration, a partner of ICTA, is carrying out E-Government projects in parallel.

Dhammike Amarasinghe, Advisor to the President, commented,

In practical terms we have to think whether the people get services in a timely manner, whether the quality of services is high. In the annual issue of revenue licences for motor vehicles, earlier you had to fill a form. Every year you had to repeat this procedure. But now the data is in the system, public do not have to provide. The procedure is easy; it takes only two minutes to issue a new licence. People are happy (Interview, 14.11.2007).

At present, several projects are underway: E-Divisional Secretariat, E-Population Register, E-Pension, Laksala, a pilot E-HRM project for the Ministry of Public Administration, and E-Foreign Employment Project for SL Bureau of Foreign Employment. These projects will no doubt improve the public sector decisionmaking and service delivery.

\subsubsection{Citizen-Client Charter}

Another attempt was the introduction of Citizen-Client Charter programme in the public sector. In 2007, the Ministry of Public Administration and Home Affairs initiated a "Citizen-Client Charter" under the banner of let's dedicate to service for protecting the rights of citizen[s]. This is one step forward by a public sector institution for providing citizens with access to information which is lacking in the public service delivery as mentioned in the earlier discussion. This Charter provides citizens with information about the task profiles, the objectives of the ministry and what citizens can expect from service delivery. In addition, it specifically elaborates the officer and decision maker responsible for each task, the time frame of the service to be delivered, and the relevant documents to be forwarded by the client to obtain the relevant services during the time frame included in the charter. There is no 
doubt that this Charter would minimise the transaction cost and enhance the transparency, efficiency and productivity of the ministry and the trust of the people in its service delivery. If other government institutions would follow the same, it may contribute to efficiency, effectiveness, and enhance transparency and access to information to the citizens.

\subsubsection{Social Indicators}

Although there are deficiencies in the administrative structure and service delivery systems, SL has achieved remarkable progress in social development which Sri Lankans can be proud of, specially achievements in education and health. SL has achieved human development outcomes more consistent with those of high income countries (World Bank, 2000). The Free Education Act of 1944 (pioneered by C.W.W. Kannangara), the change of medium in class instruction in 1945 and various reforms introduced in the education system contributed to this effect. Female literacy progressively improved from $43.8 \%$ to $90.6 \%$ whilst male literacy increased from $70.1 \%$ to $92.5 \%$, thus, adult literacy increased from $57.8 \%$ to $90.8 \%$ from 1945 2008. Life expectancy at birth increased from around 55 years in 1948 to 73.4 years in 2008. There have also been remarkable achievements in maternal and infant mortality rates: the maternal mortality rate decreased from 560 in the 1950 s to 100 per 1000 live births in 2002, while infant mortality declined from 82 to 12 per 1000 from 1945-2008. These improvements are reflected in the Human Development Index (HDI) that measures the development of a country from a broader perspective than per capita incomes. According to the HDI (0.755 in 2004) SL stands at 93 out of 177 countries (Economist, 2008, February 3). This ranking is higher than those of other South Asian Countries except Maldives. It is also higher than most countries at similar income levels. These achievements are quite impressive considering the 30 years of conflict in the country.

The other feature in the administrative structure is the large number of state-owned enterprises. The following section discusses their existence in the present context. 


\subsubsection{Public Enterprises (PEs)}

At present, SL has a approximately 210 PEs, of which 78 are commercial and the others are non-commercial, engaged in a wide range of economic activities covering trading, regulatory, research, promotional and educational activities. These enterprises must fulfil dual objectives: meeting the government's social responsibility and achieving an operational profit (Administrative Reforms Committee, 1986/88, Ministry of Finance and Planning, 2006). Nevertheless, certain enterprises must fulfil social objectives, so they cannot expect reasonable rates of return on capital employed. In 2004, twelve commercial enterprises were brought under the purview of the Strategic Enterprises Management Agency (SEMA) ${ }^{26}$, which comes under the President, in order to improve their efficiency and effectiveness and another eight enterprises were included in 2006.

The PEs are expected to be accountable to multiple agencies: the President, SEMA, minister, supervising ministry, board of directors, regulator, Parliament, public, and the Treasury (as the sole owner of equity). In addition, the Strategic Enterprises are accountable to the President and SEMA. The AG reviews accounts while the COPE oversees the public accountability matters in respect of a majority of enterprises, except government-owned companies numbering 35 (World Bank, 2003).

There are several problems in regard to these enterprises at present. One of the key problems is that the majority of enterprises lack full-time professional Chief Executives, for example, the State Plantation Corporation. Instead, tasks are being carried out under the umbrella of the politically-appointed full-time Chairman and Board of Directors. Chairmen and the Board of Directors change along with changes

\footnotetext{
26 Strategic Enterprises include: Peoples' Bank, Bank of Ceylon, National Savings Bank, State Mortgage \& Investment Bank, Lanka Puthra Development Bank, Sri Lanka Transport Board, Sri Lanka Railways, Ports Authority, Airports \& Aviation Services (Ltd), Ceylon Electricity Board, Ceylon Petroleum Corporation, National Water Supply \& Drainage Board, State Pharmaceuticals Corporation, Janatha State Development Board, State Plantation Corporation, Elkaduwa Plantation Ltd, Kurunagala Plantations Ltd, Chilaw Plantations Ltd, National Livestock Development Board, and Cashew Corporation.
} 
in government or ministers. This hinders continuous and consistent functioning of day-to-day management and development.

The other issue is that the PE is under strong political influence. This is mainly because each minister is the apex of the administrative system of the PEs. According to the State Corporation Act of 1957, "the minister shall appoint the directors from among persons who appear to the minister to have had experience of and shown capacity in industrial, administrative, commercial, financial, or legal matters, applied sciences, or the organisation of workers" (Section 12). The provision "capacity to organise workers" enables the ministers concerned to appoint anyone, other than MPs who are ineligible, on political patronage. SL experience has shown that instances where this flexibility has been taken for granted by some ministers, who have appointed unqualified persons to boards (Weerakoon, 1995). This is even more relevant today despite the fact that the Rajapaksa Committee of 1971 on Public Enterprises (Weerakoon, 1995) and ARC of 1987 emphasised the need to appoint competent people to the boards to facilitate the success of the enterprises. In one instance, the minister amended the National Youth Council Act to expand the number of board members from 8 to 24 , thereby expanding the opportunity for patronage.

Another problem is the lack of financial accountability. Several studies and reviews have already been undertaken in this sector, including a national review by leading members of the private sector, professions and civil society in 2003: Auditor General, 2006, 2007, 2008; Parliamentary Committee on Public Enterprises, 2007, 2008; Department of Public Enterprises, 2004; and World Bank, 2003. All these reviews found that the public financial accountability of these enterprises is weak and ineffective. The Ministry of Finance and Planning, 2008 highlights that over the years many of PEs has become loss making ${ }^{27}$ entities, thereby becoming dependent on excessive state subsidies ${ }^{28}$ or bank borrowings rather than paying levy/dividend ${ }^{29}$

\footnotetext{
${ }^{27}$ For example, in 2008 Ceylon Petroleum Corporation incurred a loss of SLRs. 14320 million while Sri Lanka Ports Authority made a significant loss of SLRs. 10035 million (Ministry of Finance \& Planning, 2008, pp. 159-162).

${ }^{28}$ Subsidies to public corporations (SLRs. millions): 2005 -10412; 2006 - 18,336; 2007 - 10,639; and 2008 - 12,942 (Ministry of Finance \& Planning, 2008).
} 
to government. Transfers to public enterprises in 2001 accounted for US\$446 million, about $3.1 \%$ of the GDP excluding borrowing. This situation is crucial due to many deficiencies observed by these reviews: absence of properly executed Corporate Plans (81\% of public enterprises); delays in recovery of debts; underutilisation of assets; lack of transparency in transactions, attention to profitability, liquidity and financial viability and effective internal audit; political interference in all aspects including pricing of goods and services; inadequate systems and procedures, and mismanagement (Auditor General, 2006, 2007, 2008; COPE, 2007; National Review Committee, 2003).

The key problem highlighted by the AG was that non-adherence with financial, administrative regulations and accounting standards by the PEs. The PEs are required to submit their Annual Financial Statements for audit within 60 days of the closing of financial year. In addition, the Chief Accounting Officers (Secretaries of Ministries) are obliged to submit Annual Progress Reports to Parliament in relation to the PEs under their purview within 5 months after the financial year. In spite of this obligation, the AG's Report 2006 highlighted that out of 210 PEs, only 76 had submitted their financial statements for audit within the stipulated period and the total number of Financial Statements received for audit was 165. Another 43 had been submitted later and 2 sets were yet to be submitted at the time of the AG's Report. The AG's report (2008) revealed that 20 entities had not submitted their financial statements for audit in 2008 .

The lack of proper human resource deployment is another major issue identified by the National Review Committee (2003). The senior management positions have been functioning on an acting basis for a long time while having surplus staff in semiskilled and unskilled categories. In addition overstaffing has been recognised; for example, "the Ceylon Fishery Harbours Corporation increased its staff from 129 to 640 in 2001" (Department of Public Enterprises, 2004, p.5). Owing to this situation some enterprises spend $89 \%$ of their budget on salaries such as the

\footnotetext{
${ }^{29}$ Total levy/dividend paid by the public enterprises (SLRs. million): 2008-7070; 2007-7682; 20066951; 2005-5929 (Ministry of Finance \& Planning, 2008, p.145).
} 
Samurdhi Authority and the National Youth Services Council, leaving limited funds to achieve organisational objectives, uplifting the poor and youth. It is observed that these two bodies have similar objectives i.e. promoting economic and social conditions of youth, so there is a duplication of efforts and wastage of money. The ARC already observed this dilemma, and mentioned that one of the main causes was the uncoordinated initiatives of different ministries (ARC, 1986/88, Report No.10).

Another key issue identified by COPE was the corrupt activities of the PEs which will be discussed in detail under Corruption in this chapter (COPE, 2007). The most controversial discoveries of COPE are on privatisation of some PEs, which will be discussed in detail under privatisation in Chapter 5. The COPE report (2007) criticised executives over unlawful transactions in their PEs and highlighted many deficiencies over the failure on the part of the relevant secretaries of ministries and ministers in the supervision of the affairs and follow-up of the performance of institutions which come under their purview. The recommendations of COPE were accepted by Parliament and submitted to the Bribery and Corruption Commission. However, no action has been taken by the relevant agencies, the Ministry of Finance and Planning, the supervising ministry, Parliament, and the Bribery and Corruption Commission. Therefore, the Chair of COPE, Wijayadasa Rajapaksa, MP, crossed over to the Opposition at a crucial moment, one day before the 2008 Budget was passed, criticising the government for not taking action on their findings. Dr. H.A.P. Abeywardene, former GA, in an interview said "Non implementation of COPE's recommendations will give the impression that the government is supporting the people for misappropriation of funds" (Interview, 15.02.2008). Since its inception, "COPE has continued to examine the public enterprises and has been making recommendations relating to the weak financial management, planning and performance of public enterprises but those recommendations were not given due consideration either by the Ministry of Finance, supervising ministry and Parliament" (Weerakoon, 1995, p.314)

Although COPE is a powerful Committee in Parliament, it has no power to translate its recommendations into actions. Therefore, the Parliamentary power to oversee the PEs has now become a fruitless and a wasteful exercise. Its activity is confined to a 'fact finding mission'. The cumulative outcome of non-implementation of COPE 
findings and to act on AG's reporting to Parliament was the increase of irregularities and inefficiency in PEs.

Another issue is that there is no consistency of government policy in relation to PEs. Rather, there is a tendency towards changes in policy with changes in government or ministers. This was commented on by Dr. H.A.P. Abeywardene:

The Ceylon Transport Board (CTB) was divided into regional boards and established SL Transport Board. In that background the private sector came in. Now again this government tries to reactivate the CTB (Interview, 15.02.2008).

According to Daya Liyanage "Due to this type of behaviour, the private sector is still reluctant to operate fully in development activities" (Interview, 07.01.2008). In addition, there is a tendency for non-adherence to policy; for example, the President has appointed a 75-year-old person to LankaPutra Bank, a government-owned bank, as its Chair in contravention of the Code of Governance introduced by the Central Bank (“Appoints 75 year old”, 2008).

Although existing PEs are a burden to the government, it has established several other enterprises, e.g. Mihin Lanka (PVT) Limited. However, the performances of the Strategic PEs overseen by the SEMA have not shown remarkable improvements so far. According to the Department of Public Enterprises (2005), the total revenue of these enterprises increased by $18 \%$, but the net profit of the 10 strategic enterprises before interest and tax has declined by $64 \%$.

In summary, local and foreign agencies have identified problems with the performance and functions of the PEs in SL which have adverse effects on the country's administration. Given the high prominence to PEs in the administrative structure and the economy, these issues should immediately be addressed in any future agenda of reform. 


\subsection{Part II: Public Service Cadres, Cost \& Personnel Management}

\subsubsection{Public Service Cadres and Costs}

The data in regard to cadres in SLPS reflect two aspects, (a) the confusion with regards to roles and responsibilities, and (b) the overlapping and duplication of structures and functions as discussed in the previous section.

Despite the strong recommendations by the ARC of 1986/88, UNDP (1990), ADB (1996) and World Bank (2000, 2003, 2004) that cadre rationalisation is a necessity, the cadres have continued to grow. SL's per capita employment in the public sector is the largest in the South and East Asia as mentioned in Chapter 1. Several aspects of current situations together with recent history illustrate this. As described in the ARC report the cadre strength of the public service was 406,359 in 1985. It progressively increased in later years as depicted in Figure 5 below.

Figure 5: The Public Sector Employment from 1990 to 2008

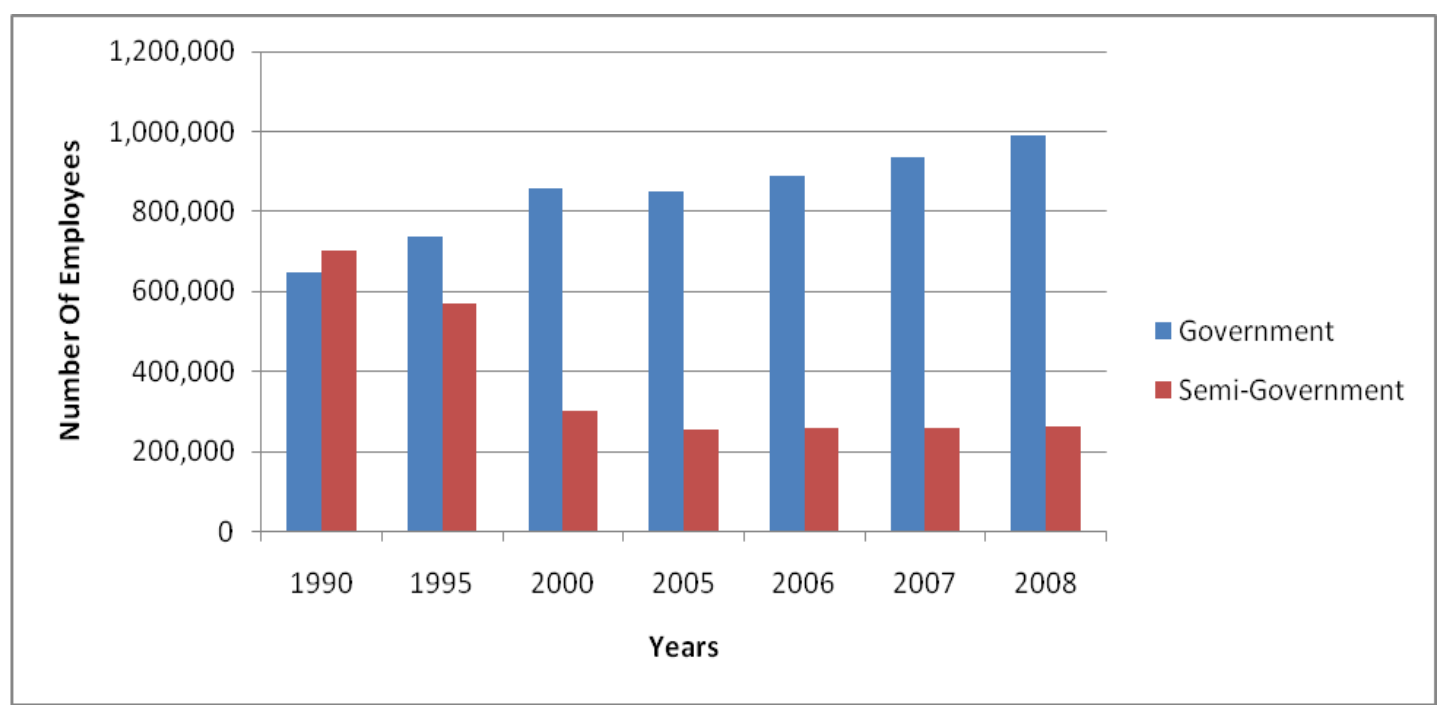

Note: Government: Central Government, Local Government, and Provincial Council Semi-Government: State Corporations, Statutory Boards, and State Authorities

Source: Central Bank, 1993, 2002, 2006, 2007 and 2009 
The current strength of the public service is 1.2 million, consisting of 990,410 in the central, provincial and local governments and 261,318 in the semi-government sector as at 2008 (Central Bank a, 2009, p.90). Figure 5 illustrates declining trends of semigovernmental employment over the period and proliferation of the government sector. Since 1990 the numbers of public sector employees have increased by almost more than $37 \%$ amounting to $13 \%$ of the total labour force at the end of 2008 .

However, there was a slight decline between 2000 and 2005. In 2001 there was a suspension of recruitment to the public service by abolishing existing vacant posts by the UNP government (Management Services Circular No. 16, 2002). This government was dissolved by the President by using her executive power as mentioned before. One of the election pledges of the SLFP related to public sector employment. They promised to give government employment to all unemployed graduates. ${ }^{30}$ The election 2004 gave power to UPFA led by SLFP. One of the reasons for the defeat of the UNP was the suspension of recruitment to the public service. This was emphasised by senior Ministers of the UNP in the aftermath of the election. Finally, 19 members crossed over to the government accusing the UNP leadership of suspending recruitment, among other things.

In 2004, this suspension was withdrawn in respect of staff posts in the public service (Management Services Circular No.23, 2004) by the new government which recruited 12,000 unemployed graduates in 2004 and another 41,480 in 2006 (Ministry of Finance and Planning, 2005 \& 2007).

According to the Report on SL Development Policy Review by the World Bank (2004, p.12),

This bureaucracy is large, costly and suffers from low effectiveness and efficiency. The incentive system is perverse. Government workers with the lowest levels of education on average earn almost double the wages of their private sector counterpart. Top policymakers and professionals are insufficiently compensated. Controls on recruitment have weakened over time. Despite the growing role of the public sector and increased privatisation, government employees have risen in both absolute numbers and as a proportion of labour force...politicisation of public recruitment has weakened the norms

\footnotetext{
${ }^{30}$ The youth unemployment is very significant in SL. It was never below 8 percent (Ministry of Finance and Planning, 2006). It was reported around 45,000 graduates are unemployed at the time.
} 
prevailing in the administration, bloated its numbers and reduced the effectiveness.... Rising government recruitment has gone hand in hand with the proliferation of government institutions in the past 20 years.

The Central Bank figures in relation to semi-government employment for the years 1998 and 2002 were different from that of figures provided by the Department of Census and Statistics. According to the Central Bank, in 1998 there were 300,654 employees in this sector whilst it was 213,789 according to the Department of Census and Statistics. In 2002, the employment data of the Central Bank was 264,355 whereas it was 272,441 according to the Department of Census and Statistics. In the first instance the variation is huge. The Central Bank figures show increased employment in this sector in 1998 and decreased employment in 2002 when compared with the data of the Department of Census and Statistics which is "the central statistical agency in SL, responsible for collection, compilation, analysis and dissemination of all statistical data needed for planning, policy formulation and to monitor the progress of various development activities and also to measure the impact of various governmental policies" (Department of Census \& Statistics, 2009). In this scenario one may puzzle over which data is accurate or which data is to be used in decision-making. This is only one area. Other data may also have the same ambiguity. Due to the lack of a management information system on public sector employment in the Ministry of Public Administration, the apex body for Public Administration, which was established 36 years ago, the ambiguity of data on public sector will persist, thus management decisions will be handicapped. Therefore, it is necessary to rely on coordinated statistical database for the country in order to make coherent and consistent policy decisions. This should be taken into account in the formulation of future reforms.

The salary bills were increased accordingly; the expenditure on salaries in 1995 was SLRs 25,340 million. They were raised to SLRs 121,841 million in 2005, SLRs 175,031 in 2006, SLRs 214,160 in 2007 and SLRs 239,078 in 2008 (Ministry of Finance and Planning, 2008, National Council for Administration, 2006). According to the Annual Report 2008 (p.67) of the Ministry of Finance and Planning, the expenditure on salaries and wages is the highest single expenditure item of the national budget. It represented $5.4 \%$ of GDP and $32 \%$ of the total recurrent expenditure in 2008. Salaries and wages absorbed 36\% of total revenue in 2008. 
The public personnel management policy has direct bearing on the increase of the public sector cadres and expenditures. The next section examines the current situation of the personnel management system of the public service.

\subsubsection{Personnel Management}

The personnel management policies and approaches in the public service demonstrate the degree of efficacy of the country's public administration to a large extent. This section discusses the agencies involved in personnel management functions of the SLPS with special reference to NPSC and current personnel management modalities including recruitment, transfers, training, and promotional policies, in order to understand whether they contribute to organisational efficacy and efficiency of the country's public administration. Furthermore, it outlines the fundamental policy issues, weaknesses and outcomes in an attempt to address them in any future agenda of reforms.

\subsubsection{Agencies Involved in Personnel Management}

The personnel management powers and functions of the SLPS are vested with the National Public Service Commission (NPSC) and nine Provincial Public Service Commissions (PPSCs) and the Police Commission. The evolution of NPSC and its associated constitutional reform will be discussed in Chapter 5 in detail. The National Salaries and Cadre Commission (NSCC), which was established in 2006, is entrusted with advising and assisting the Government in formulation and development of a wage policy and cadre management in the public sector (Gazette No. 1444/8, May 9, 2006). The Ministry of Public Administration and Home Affairs is dealing with the delegated functions of the NPSC relating to Combined Services (Appendix 7). The approval and review of cadre are the main task of the Management Services Department, thus the ambit of its functions is more or less duplicating the tasks profiles of the NSCC. The National Budget Department also becomes involved in the field of personnel management of the public service by controlling the cadre in terms of the manpower budget in the annual estimates. This section does not attempt to discuss the functions of each organisation mentioned above but will discuss the composition and role of the main agency, NPSC. 


\section{National Public Service Commission (NPSC)}

The NPSC in its present form was established in 2001 under the $17^{\text {th }}$ Amendment to the Constitution. It is composed of nine members, appointed by the President on the recommendations of the CC. As mentioned in Chapter 3, the CC is now ineffective, thus the current members are directly the appointees of the President. The NPSC is responsible for appointments, promotions, transfers, disciplinary control and dismissals of the public officials except members of the police service, provincial public service, secretaries of ministries, heads of departments and employees of public enterprises (see Chapter 3). In this sense the NPSC has no power over key positions of the public service. This could lead to nepotism, allegiance, and political patronage by the executive over such appointments.

However, the NPSC has the power to make rules, regulations and procedures relating to the public service as a whole, while the Cabinet of Ministers have the power to make policies. Until the Commission made its own rules which came into effect from April 2009, the existing Establishments Code had served as the guiding principles of NPSC from 2001.

According to Articles 56 and 57 of the Constitution, the NPSC has the power to delegate its powers to committees or public officers subject to the conditions and procedures determined by the Commission (Appendix 7). Any public officer aggrieved by an order made by a delegated authority in relation to appointment, transfer, dismissal and disciplinary control, can appeal to the NPSC in accordance with such rules made by the Commission from time to time. The Constitution gives the NPSC power "to alter, vary, rescind or confirm" an order against which such an appeal has been made. Article $61 \mathrm{~A}$ of the Constitution does not allow any Court/Tribunal to intervene in decisions of the NPSC other than fundamental rights applications and appeals to the AAT which was discussed in Chapter 3. The immunity conferred by Article 61A has already been recognised judicially by the Court of Appeal (CA), for example, CA No. 283/2003 - Katugampola vs. Commissioner General of Excise; CA No.16/2004 - Ratnasiri vs. Ellawala; and CA No. 18/48/2006 - Perera vs. Director General Customs and others (Goonawardene, 2007, May 21). In these cases the Court ruled that a decision taken by the NPSC 
cannot be challenged, except at the AAT. Accordingly, the NPSC has been given full autonomy in relation to the matters of personnel management in the public service.

The independence of the NPSC is also guaranteed by Article 54 (2) of the Constitution which prohibits the appointment of MPs, Provincial Councillors or members of local authorities to the NPSC. Secondly, the removal of members can be done only by the President on the recommendation of the $\mathrm{CC}$ or if convicted by a court of law for any offence, or by the imposition of civic disability. Thirdly, the independence is ensured through the determination of the emolument of Commissioners by Parliament. Fourthly, the independence was ensured through Article 61(c) of the Constitution, which states that any person, without authority under the Constitution, who attempts to interfere or influence the Commission or any public officer, shall be guilty of an offence and subject to imprisonment or a fine.

The Cabinet of Ministers have the powers of appointment, transfer, dismissal and disciplinary control over Heads of Departments (HODs) under Article 55(3) of the Constitution subject to 'ascertaining the views' of the PSC. This is a major departure from the previous Constitutional regime in which Cabinet had sole authority in all aspects of personnel management functions, not only the HODs, but also the whole public sector. Accordingly, it is now expected that Cabinet would consider views of the NPSC in taking a final decision.

Hence, the Cabinet retention of powers over HODs is a concession made by the new constitutional change for the convenience of the Government of the day. According to D. Wijesinghe, Secretary to Cabinet, "there have been instances where the Cabinet had to reverse its earlier decisions due to the contrary views expressed by the NPSC. However, there is still a school of thought that these powers also should be taken away from the Cabinet and vested in the NPSC" (Interview, 12.11.2007).

The powers for appointments, transfers, dismissal and disciplinary control of Secretaries to Ministries are with the President. Article 52(2) states that,

The Secretary to the Ministry shall, subject to the direction and control of his Minister, exercise supervision over the departments of government or other institutions in charge of his minister. 
This Constitutional provision has several shortfalls. It undermines the impartial and effective discharge of advice by the highest official in public offices. Since the Minister has been given powers constitutionally to direct and control the Secretary as he/she wishes, the Secretary may be reluctant to give 'free and frank' advice rather than implementing the orders of the Minister. As such, a Secretary is ambivalent about public values versus political interests in policy formulation. On the other hand, a Secretary may expect direction from the Minister, which can handicap innovativeness in the public sector. This situation becomes worse due to the fact that the power of appointment and dismissal of the Secretaries is vested with the President. Dr. B. S. Wijeweera, former GA, commented,

The public sector individual feels that he will be obliged to be a mere instrument of the government once he gets to that office. Although it is not a political appointment ${ }^{31}$ but the position or the post itself has got immersed in politics and people reacting in a political way when they are invested in that office. [In order to survive in the high office] (Interview, 09.01.2008).

Currently several retired public officials hold secretarial posts. This is a matter of concern which obstructs other people from getting into those positions.

In summation, the powers of appointment, transfer, promotion and disciplinary control of public officers are currently vested with the NPSC. The NPSC has delegated some of its powers, such as disciplinary control and transfer, to public officials subject to some conditions. Its original powers of appointments and promotions have not been delegated. However, the NPSC does not have personnel management powers over the Secretaries of Ministries, Heads of Departments, employees of Public Enterprises, and provincial cadres.

\subsubsection{Appointments}

As discussed, the power of appointment of personnel to the national cadres of public service is constitutionally vested with the NPSC. However, there are instances where this formal approach has been avoided, and various forms of informal modalities have been adopted in the recent past. The major difference between formal and informal approaches to appointments is that the former recognises the merit of the

\footnotetext{
${ }^{31}$ Majority of the Secretaries of Ministries are career bureaucrats.
} 
person and selects the best following systematic approved procedures (advertising followed by the competitive examinations and structured oral tests according to 'service minutes' and schemes of recruitment), while the latter ignores those and selects people either on patronage or based on subjective judgments and criteria. Nevertheless, recruitment of personnel to the SLPS following the approved procedure is not without problems.

\section{Formal approach}

The current modality of recruitment to core managerial groups is based on the concept of 'All Island Services'(AIS) which recognises the uniformity of recruitment to countrywide groups and lifetime permanent employment, rather than emphasising the specifics of the job.

Despite the fact that the present administrative system (development administration) demands more specific skills, this recruitment to island-wide groups continued after Independence; for example, from the Ceylon Civil Service to the present Sri Lanka Administrative Service and expanded to every other profession: planners, accountants, teachers, scientific officers, architects, and medical cadres (Wanasinghe, 2005). The outcome was the proliferation of 11 AIS in managerial groups (Appendix 7) and four major subordinate groups (Management Assistants, Librarians, Drivers and Office Employment) in the administrative machinery (excluding teachers and armed forces). For general administration there are two services: the Sri Lanka Administrative Service (SLAS) and Educational Administrative Service.

The appointments to the AIS are carried out by the NPSC and their management is performed by several other agencies; for example, the Combined Services Department is delegated with the transfers and disciplinary functions of the SLAS, while the Planning Service Board and the Scientific Service Board are entrusted with Planning Service and Scientific Service cadres respectively. There is no consistency in this administrative arrangement because some services are managed by boards and some by the Department of Combined Services. These are additional costs to the government. 
Though the country-wide recruitment policy has some positive outcomes such as reduced cost, easy coordination of recruitment and induction training, and reduced time-wasting, its negative outcomes are overwhelming and hinder efficient and effective public service. They include highly centralised recruitment; insufficiency of specialisation; absence of commitment to the institution in which one serves; difficulty of enforcing accountability for task performance; proliferation of several management bodies in the administrative system, and service orientation rather than job specificity.

Because of the centralisation of appointments, public sector institutions have become just passive recipients of personnel from the services which are assigned to them. Public institutions have to manage with the personnel supplied and they lack authority to match those supplied with specific job requirements (Wanasinghe, 2005). The outcome is that the right person is not always in the right place, thereby creating organisational inefficiency. In addition, the authority of the immediate organisation in relation to personnel management of the AIS cadres is insignificant: no personnel responsibility in regard to recruitment, disciplinary matters, and transfers. The trend of centralisation is exacerbated by the dominance of the AIS in the bureaucracy, even in the provincial governments. There is also an insufficiency of specialisation. This becomes worse due to lack of job-specific training for the higher echelons ${ }^{32}$ who are supposed to run the ministries and departments.

Similarly, service orientation hinders cohesiveness within the bureaucracy; for example, in the Treasury, the External Resources and National Planning Departments are dominated by the Planning Service cadres, National Budget and Fiscal Policy are dominated by Administrative Service cadres, and Treasury Operations and State Accounts Departments are dominated by Accountant Service cadres. They are reluctant to have cadres of other services in their respective departments. In 2004, the Treasury transferred some newly-recruited SLAS officers to those departments in order to have multi-skilled people to improve productivity, but those posted to the

\footnotetext{
${ }^{32}$ A current Secretary of a Cabinet Ministry commented that he has no specialisation in the functions of his ministry, so that he has to learn on the job. He further mentioned that when he masters the subjects and becomes specialised, there may be a Cabinet reshuffle with a transfer of Secretaries. Thus, there is no point to study hard, so it becomes a learning exercise again and again because the higher echelons groups are not readily available to take up specifics of jobs. This problem persists because of failure to create the Senior Management Group as recommended by the ARC, 1986/88.
} 
State Accounts and Treasury Operations Departments were not given meaningful tasks, so later they moved to other departments where they felt they were not being discriminated due to two different services (personal observation). The service orientation in the public sector badly affected the utilisation of cadres. Engineers and medical cadres, too, are engaged in administrative tasks irrespective of their specialisation, for example, in the Department of Irrigation and Ministry of Health. This wastes their talents.

Dr. B.S. Wijeweera, former GA commented,

I personally feel that we have now come to the stage when AIS are an anachronism. The management of them is very difficult. We must now swing to a decentralised set of services where people prove their allegiance to a particular province and the staff within the province become transferable within the province, but not on an all island basis. The main weakness of AIS now is that it tends to centralise talents in Colombo because all the top jobs are in Colombo. People tend to migrate to Colombo when they mature [reach senior]. That is not good for the administration. The mature [senior] people should be encouraged to be in the province where development takes place (Interview, 09.01.2008).

In conjunction with these issues of recruitment is the tenure of employment of public officials. The lifetime employment is the main pillar of the SLPS. Though it contributes to attraction and retention of officials and security in the public service, it also:

Poses considerable impediment to the rationalisation and restructuring of public administration institutional structures;

Contributes to considerable surplus staff when their jobs become unnecessary consequent to such rationalisation;

Inhibits possibilities of inducting personnel for new specific short term contract; and

Introduces a situation of rigidity and inflexibility thus, impeding administrative reforms (Wanasinghe, 2005).

However, this formal approach to recruitment has been ignored sometimes by SL government; further complicating matters and undermining the new constitutional provisions and merit principles, and even ignoring future needs of public administration. This process undermines the 'Mahinda Chintana' which pledged "I 
will restore the dignity and independence of the public service" (Rajapaksa, 2005, p. 9). The next section examines informal and ad hoc approaches to recruitment in the SLPS.

\section{Informal and ad hoc Approaches}

There have been some irrational appointments to the AISs irrespective of the merit principle. These appointments are based on the recommendations of the committees appointed to give redress to public servants who complained of political victimisation. This approach was not only for recruitment but also extended to promotions in the public service too. However, it is evident that most of such appointments in the past were patronage politics rather than genuine cases of political victimisation (personal observation).

As mentioned, the Cabinet of Ministers currently does not have power over appointments but they manage to make ad hoc appointments, for example, since 2005 the Ministry of Science and Technology is running "Vidatha" Programme (Transfer of technology to village), recruiting people completely outside the public service.

The Secretary to the Cabinet, D. Wijesinghe, said that although all public service appointments, below the rank of Head of Department, are to be made by the NPSC, there are occasions when ministers have to get persons appointed outside this stipulation, either due to the delay in following NPSC procedures or as persons in whom the Minister has personal confidence are required. Hence, some appointments have been made on a contractual basis, for a limited period of time, on the approval of the Cabinet of Ministers. He cited the example above to illustrate the point ((Interview, 19.11.2007). In addition, there are many appointments such as advisors in many ministries and departments based on political patronage. The Cabinet Secretary further said,

There are also instances where, at a higher level, personnel have to be hired, to attend to specific duties outside the routine functions of public officers. Here, this is not possible within the strict procedures laid down by the NPSC. Therefore, several ministries have appointed, again with Cabinet approval, a number of advisors/consultants, on contractual basis, for a limited period of time (Interview, 01.11.2007). . 
The Cabinet Secretary has, in respect of both cases mentioned above, advised the Cabinet of Ministers, on the constitutional and legal positions, but, such appointments continue to be made.

Although the numbers of political advisers in ministries and departments escalated after 2005 , this study focuses more on other general appointments which were eventually made permanent without due qualifications to handle the positions. Inducting personnel for new specific time-bound tasks may become necessary as the task demands on public administration continue to change. However, those appointments should be terminated at the end of their contract. Nevertheless, it has never happened. The recent past experience shows that in general temporary appointments were later made permanent by the Cabinet. Public Administration and Home Affairs Circulars: 21/2006 and 21/2006 (i, ii, iii and iv), have implemented such Cabinet decisions and granted permanent status to all temporary appointees who have completed 180 days satisfactory and continuous service irrespective of having the required qualifications. The decision to recruit people temporarily and then grant permanent status to them in such a manner gives priority to patronage and needs of individuals rather than the needs and interest of public administration. This leads to public service disarray.

Furthermore, it leads to other issues: lack of discipline and degradation of the quality in the public service, demoralisation of the existing staff, and further distortion of neutrality and impartiality principles which are the guiding principles of withdrawing the Cabinet of Ministers from personnel management by the $17^{\text {th }}$ Amendment to the Constitution. This informal practice further undermines the authority of the NPSC given by the Constitution, thus hindering good governance.

Moreover, despite the bloated public service, there were countrywide appointments for graduates by creating unnecessary posts in the recent past to ease the unemployment problem. V.K. Nanayakkara, former Secretary for the Ministry of Education responded:

The government recruited 43000 graduates in the recent past. The entire Art graduates who were in the Private Sector also have joined the public service. I asked one graduate why he joined the public service with a low salary. He replied, in the private sector I had to work very late. I joined the public service because I want to be free. Even with a low salary people like the public service because you get a pension. You can go up without even doing anything, sign the book and draw your salaries. There is no performance 
based promotional system. Everybody gets a satisfactory evaluation at the end. You are free. In the private sector they have to learn IT, acquire marketing skills and so on. In the public service there is no such requirement. So the government gave a wrong signal to youth.

He went on saying that,

They appointed 10,000 Arts graduates [from 43000] to the teacher service. Those teachers are not required by the ministry. We needed aesthetics, science, maths, Tamil and English teachers who are in short of supply, but none of them had that background. Unnecessarily we filled the teachers' cadre with graduates who are in excess. It is a political decision (Interview, 14.11.2007)

The ARC (1986/88) had foreseen this situation and pinpointed that the Committee does not see the public service as the natural provider of employment for the large numbers who emerge from the educational system. Professor S.W. Ranasinghe observed that the academia today is not playing its legitimate role properly.

This situation was reinforced by the former Secretary to Education, V.K. Nanayakkara:

Our university system does not provide the necessary manpower for the country. This is a serious problem. Why do they produce lots of Arts graduates? The doctors cannot work without nurses, dispensers, technical officers, x-ray technicians, lab assistants so on. We produce doctors, and engineers; but we do not produce assistant staff. Our universities do not produce nurses, technical experts who are needed to the country. We can export nurses but we cannot send Sinhala graduates abroad. We do not have polytechnics. We should have more vocational training schools (Interview, 14.11.2007).

Nevertheless, the public service has become the natural provider of employment for large numbers and the persistent platform for 'state building'. This problem will continue due to the accumulation of graduates each year.

Though this kind of recruitment provides a temporary solution to the existing social problem of unemployment, it has several far-reaching negative outcomes. A major negative outcome is that it encourages unemployed personnel to search for government employment rather than adapt themselves to the needs of private employers, and then search for and accept private employment (World Bank, 2000).This also affected the negative outcome of the labour deployment of the country (Central Bank, 2006). The large number of appointments further encourages the expectation that government employment could be achieved at any time, in any number, and any field. For example, in 2007, Indigenous Medical Graduates who 
were supposed to be in private practice, also demanded public sector employment and the current unemployed graduates established a 'Combined Unemployment Graduates Association' and conducted protests against the government in July 2008, demanding that the government fulfil its promises to unemployed graduates made during the period 2006-2008.

The other negative outcome is underemployment of staff in the public sector. Ronnie De Mel, Senior Advisor to the President, said, "Most of the new graduates do not have work. Go to a Kachcheri ${ }^{33}$ and see how many people are idling" (Interview, 05.12.2007). The Minister for Education; Susil Premajayantha also commented, "They are not utilised because they are not required. They are appointed on a political decision. There was no actual necessity” (Interview, 19.02.2008).

The wastage of manpower is wastage of money. Therefore, it is imperative that they must be properly utilised.

There are other instances where Cabinet took decisions on such ad hoc appointments in the public service but the NPSC did not implement those decisions. The aggrieved public officials even sought SC intervention, for example, the SC Case No. SC F/R 146/2003 -in respect of Cabinet decision of 12.10.2001:

Grant approval to create 8 posts of Assistant/Deputy Directors of Pirivena ${ }^{34}$ in the Education Department;

Appoint 8 persons holding the positions of Pirivena Coordinators to these posts; and

Absorb 10 Lecturers serving in a Pirivena (Goonawardene, 2007).

In this case the SC highlighted that the Cabinet does not have power to appoint certain people or categories of people but does have policy making powers, thus, the Court decided that only the first decision comes within the powers of the Cabinet according to the law. Nevertheless, the Cabinet took a similar kind of decision on

\footnotetext{
${ }^{33}$ Kachcheri or District Secretariat in the present context is the core administrative body in the district.

${ }^{34}$ Pirivena is the place where Buddhist monks study.
} 
December 13, 2004 (Goonawardene \& Wijesinghe, Interviews, 11.02.2008 \& 12.11.2007 respectively).

According to D. Wijesinghe, Secretary to the Cabinet (2007), in both cases the decisions were taken to address the grievances of two specific groups of public officers, but now they have to go to the NPSC. However, the NPSC cannot appoint them outside the Schemes of Recruitment which will not eventually fulfil the ambitions of the persons concerned. It is regrettable to note that in these two cases the Cabinet acted to fulfil the wishes of the persons concerned damaging the quality of the public service and its future.

These are the examples of using the public sector for political gains by party politics, further bloating the already-bloated public service and posting those appointees irrationally throughout the country, creating a 'winners take all' situation. The Daily Mirror editorial ("Unqualified teachers", 2007, p.8) disclosed that there were 12,000 unqualified teachers in the country's education system from 1989. There has been no action taken by any successive governments in this regard. The current ad hoc appointment to the public service leads to organisational ineffectiveness and low quality outputs and outcomes. This eventually, no doubt, will be a bottleneck to the economic development of the country.

The most probable main reason for intervention of the Cabinet of Ministers in the public service appointments and trying to maintain the pre-constitutional amendment modalities is expressed by the Secretary to the Ministry of Petroleum and Petroleum Resources Development, A.P.A. Gunasekara,

Politicians failed to make development activities in the country in order to address the problems of the citizens. Therefore, they try to give something through the public service. During our time the appointment letter was delivered to us through the post. But now, they are handed over by the ministers at big functions. Same with other services such as Samurdi benefits [welfare], state land distribution, etc (Interview, 21.11.2007).

In summation, despite the devolution in late 1980s, centralised and countrywide recruitment to the public service still exists. The AISs dominate in every field of core managerial positions. The lack of organisational specificity due to the high rate of transfers (see 4.3.2.4), in conjunction with lack of job specific training for the higher echelon of public officials, needs immediate attention because they heavily impact 
on day-to-day administration. The current modality of ad hoc temporary appointments and later absorption to the permanent cadre without qualifications also needs special attention in any future reform in order to preserve the quality of the workforce and to enhance the achievement of the organisational objectives.

\subsubsection{Personnel Planning}

SL public administration suffers from lack of personnel planning. This is another area which needs immediate attention. The activities of the personnel planning include forecasting the human resource requirements in accordance with the needs for administration and development over a period considering retirement, and resignations, selecting the right persons to the right positions, training them to undertake specific tasks and retaining them by paying adequate salaries to live with dignity. However, in the SLPS personnel planning is marginal and nobody pays attention to it.

One of the weaknesses of the lack of personnel planning in addition to the excess cadre already discussed is that it has led to an imbalance in cadres in public organisations. Although the overall cadre is excessive in the public sector, most of the organisations are reporting that they are short of staff in several categories. According to the Minister for Transport the number of directors in the SL Transport Board is much higher than the workers and there are other vacancies to be filled ("SLTB overstaffed", 2007). The health sector is short of specialists, qualified nurses, and technical staff. Furthermore, the public service has an excess in office employees (peons, messengers, and unskilled labourers, currently $(2008-14,000)$ in the national cadre and drivers (5500)). This is because after every election the winning party appoints their political supporters to these positions.

However, the public service acutely lacks translators, journalists and IT professionals. According to the present Constitution, both Sinhala and Tamil are official languages. In addition, English is being used as a link language. While communication with a citizen may be in one of these languages (depending on what language the citizen would like to communicate in), all official records and general 
communications have to be in all three languages. The Cabinet Secretary, D.

Wijesinghe, outlined the problem of working in three languages in an interview:

This is especially so in a place like the Cabinet Office, where Cabinet papers Memoranda, Minutes and Decisions, have to be maintained in Sinhala, Tamil and English. This presents not only logistical problems (like getting documents in three languages on time), but also finding competent translators to put documents prepared in one language to the other two. Consequently, Cabinet Office had to engage even translators, over the retirement age of 60 - one even 72 years of age (Interview, 19.11.2007).

In addition, due to the lack of a proper manpower planning system in the public service, there are regional imbalances in manpower supply.

\section{V.K. Nanayakkara explained his experiences in the Ministry of Education:}

In the teacher service there was overall excess staff in Sinhala medium. In the Southern province, there are regional imbalances. Galle and Matara have excess but Hambantota is short of teachers. Schools in Anuradhapura town have enough teachers but in remote areas like Kabilithigollawa and Padewiya teachers are in deficit. We cannot transfer from excess to vacant places because of politics (Interview, 14, 11.2007).

Why does the ministry not transfer excess teachers to other vacant schools? The Minister for Education commented,

Because of many reasons, socio-economic and political, it is very difficult to implement a transfer policy. Most of the teachers want to work in towns for better facilities. They do not want to go rural areas. Their attitude also should be changed (Interview, 19.02.2008).

This situation is not only confined to the education sector, but in other sectors too, including the district administration; for example, Divisional Secretaries in the rural areas are below required qualifications as mentioned. Out of 312 divisions only 110 currently have Class 1 officers because most of the Class 1 officers are reluctant to work in divisions where they are more vulnerable to political interferences ${ }^{35}$.

A.P.A.Gunasekara, Secretary, Ministry of Petroleum and Petroleum Resources Development, commented:

Previously a public officer in the division had to satisfy the MP in the area, but today he has to satisfy many politicians, provincial council ministers, provincial councillors, pradeshiya sabah members and even the organisers in the ruling party. A Divisional Secretary (class 1 officer of the SLAS) who was posted to... division faced a big

\footnotetext{
${ }^{35}$ For example, Matale, Wellawaya and Ampara Divisional Secretaries were transferred out on the request of the political elites recently (Ministry of Public Administration and Home Affairs, 2008)
} 
problem on the very first day of his duty. A pradeshiya sabha member has come and asked him who are you? Then he replied that he is the new DS to this office. Then, he was asked "how did you come to this office without my knowledge? The officer has replied that he didn't know, the Ministry of Public Administration and Home Affairs appointed him to this position. Then the politician threatened him and asked him to seek a transfer immediately, if not he would be in a trouble. How can one work in such an environment? (Interview, 03.01.2008).

In summation, the above review of the current position of the personal management of public service reveals that there are no cohesive public sector personnel management policies. The cumulative outcome of the existing situation in regard to recruitment and placement functions is the increasing trend of organisational backwardness, inefficiency, inability to deliver the outputs which are expected from the government policies and programmes, continuous politicisation, and bloated bureaucracy. Due to the fact that the public administration has to maintain such a huge number, it has become an obstacle to socio-economic development because the money available is spent on maintaining huge cadres. The unwillingness to rationalise cadres in the public service, despite the recommendation of the ARC of $1986 / 88$, led to the current situation. Hence, the centralised countywide recruitment, failure to follow the standards of recruitment, proper placement on the job and personnel planning are matters for concern in any future reforms.

\subsubsection{Transfers}

According to the Establishments Code which sets out policies, rules and procedures of the Public Service, all public officers are obliged to work in any part of the country thus, they are subject to being transferred. The NPSC has delegated its power on transfers to relevant public officials (Appendix 7). H.D. L. Goonawardene, Secretary NPSC, in an interview said,

The Secretaries of Ministries can implement transfers according to the specified scheme approved by the NPSC, but the NPSC has received a lot of petitions on political transfers. Without any authority secretaries make ad hoc transfers. On such occasions the NPSC issues stay orders and go into the merits of the case and sometimes the NPSC stps them and try to rectify. Even under the urgency of work the secretaries now cannot transfer their staff in an ad hoc way (Interview, 11.02. 2008).

Nevertheless, due to countrywide recruitment to the public service, the transfer of staff is inevitable despite the devolution of administration. It hinders the specialisation of tasks by public officials. It also develops lack of commitment on the 
part of staff to the institutions in which they serve. A public officer has the feeling that the work station is only a 'temporary place' for him. Public organisations lack people with organisational history due to the frequency of transfers. Sometimes transfers create psychological problems to public officials and their families. This creates additional costs and tasks to government departments. However, as mentioned by the ARC, transfers are sometimes needed for the sake of the individual officer and the organisation.

\subsubsection{Promotions}

Promotion is another area where patronage is exhibited in the SLPS. Promotion is an instrument for selecting from amongst serving public officers those who are best equipped in terms of ability, aptitude and attitudes for the performance of tasks in a position at a higher level in the public service (ARC, 1986/88). Under the new constitutional regime powers of approval of promotions in the public service are vested with the NPSC. That power has not been delegated to any public official. In regards to Combined Services promotions are done according to ways that are spelt out in the Service Minutes. Those who fulfil the requirements of the service minute are promoted to the next Grade. However, as mentioned before, the powers of appointment to the higher echelons, Secretaries to the Ministries, Deputy Secretary to the Treasury and Heads of Departments, Additional Secretaries, are vested with the President and the Cabinet respectively. The promotional prospects of Class 1 officers of AIS are in their hands. Although one can go up to Class 1 on merit, one cannot go beyond such a position only with ability and merit.

Daya Liyanage, chair of the National Procurement Agency commented:

You can get the promotion but you cannot get a position unless you are recommended by the Cabinet. What is the use of having the promotion without a suitable position? (Interview, 02.01. 2008).

Due to the lack of a proper performance appraisal system in the public service and performance-related systematic promotional systems, appointments to higher posts are not made without 'patronage', politically or otherwise. In regard to public enterprises, promotions are done in an ad hoc manner. 


\subsubsection{Performance Management}

Although performance monitoring and evaluation provides the underpinning for a proper performance management system in the SLPS at all levels, it is yet to be introduced at macro and micro levels. In 1966, with the enlargement of government functions, a "National Operation Room" was established to monitor the performance of vast area of development initiatives (ADB, 2004b). However, performance management was neglected thereafter. In 2003, the "National Operation Room" was re-established by the UNF government, but due to it being short-lived that government initiative was interrupted. Performance management is further exacerbated due to the fact that the annual budget of the government is inputoriented. Therefore, there is no outputs/outcomes based performance evaluation system in regard to public goods and services delivery at present.

At the micro level, an individual performance appraisal (PA) system was introduced in 1998 (see Chapter 5 for details), to discard the confidential reporting system which was in practice, to promote accountability, and to bring the public sector service delivery to a high standard. The evaluation gave higher weight to work-related aspects to ensure a higher level of objectivity and fairness.

Nevertheless, soon after it was introduced, the whole process of PA proved flawed due to many reasons: lack of knowledge of officials on how to formulate and use the appraisal results; inadequate participation of the appraisers in the preparation of work plans; unwillingness of appraisers to make accurate evaluations due to cultural norms, and lack of any feedback mechanism. Furthermore, the lack of consistency and commitment in the way PA is implemented; lack of incentives to high performers and/or sanctions to non-performers; lack of integration of PA with other human resource decisions such as promotions and training; political interference in recruitment, promotion and transfers; and the fact that PA generated a lot of paperwork, hindered the effectiveness of the PA system in the public service (De Alwis, 2000).

At present individual PA system has become a form-filling exercise. Everyone gets a satisfactory rating irrespective of performance at the end of the year. The 
performance of the Secretaries of the Ministries is not under any appraisal. Most importantly, there is no environment in the SLPS to seriously evaluate performance because appraisal results are ignored in key human resources decisions across the public sector.

\subsubsection{Training}

Public servants are needed to acquire updated knowledge and skills in diverse sectors in the economy in order to contribute effectively in socio-economic development of the country. In addition, overseas exposure is very important for public officials, not only to acquire relevant knowledge, skills and good governance practices overseas, but also to understand how they should be ready to face challenges of ever changing competitive global environment. Therefore, training should be an ongoing process for equipping cadres from entry throughout their career, facilitating them to perform responsibilities effectively and professionally.

There is no National Training Policy for the SLPS to develop personnel systematically to gain professionalism. The need for professionalism is ignored. Accordingly, the overall current position in the human resource development in the public service is marginal and supply-driven. There is no consistent policy or direction on how one should acquire necessary skills over a total career period for specialising in a key career path or a couple of key areas; for example, development administration, and development of economic infrastructure,. This is particularly more relevant for the managerial cadres who are going to take up senior management positions.

The training needs of SLPS depend on the individual officer's initiatives rather than on specifics of organisational needs. Those who are ambitious and enterprising in their career development, often undergo readily available training programmes whilst the majority undergo training just to comply with the requirements of the respective "service minutes." Also, officers who are based in Colombo often take more such opportunities than cadres in divisional and district levels. The reluctance to release officers for training, non-availability of staff provisions for replacing released officers, inadequacy of budgetary allocation due to lack of priority for HRD and non- 
adequacy of provincial training mechanisms are at the heart of the present system of HRD in the SLPS.

There are several national training organisations which deal with training and capacity building in public administration, namely: Sri Lanka Institute of Development Administration (SLIDA) for managerial staff; Public Service Training Institute for non-managerial staff; Rural Development Training and Research Institute for field staff; Institute of Government Accounting for Accounting staff; and the National Institute of Business Management for corporate sector employees.

SLIDA plays a major role in training and capacity building in the public service In 2003, it was granted postgraduate credentials by the University Grant Commission. Nevertheless, SLIDA's attention for training senior managers to handle the specific tasks is minimal. When it occurs, it assumes a generic and academic form, unrelated to the specific organisational objectives, task demands and performance enhancement needs of the specific organisation (Wanasinghe, 2005). Due to this reason and perhaps other factors, the scheduled posts of SLAS are occupied by other cadres; for example, Director General, Fiscal Policy of the Treasury is gazetted as a scheduled post of the SLAS (Minute of the SLAS, 2005), but for more than half a decade that position has been held, and is still held by the Central Bank official seconded to the Treasury. The Ministry of Public Administration and Home Affairs or the Treasury do not have any such training plan for administrators.

The contribution to building administrative and management capabilities by other organisations mentioned above are marginal due to the financial constraints and lack of trained trainers. There is no coordination between these organisations in providing the training needs of the public service. They perform independently, so that training needs are not met and budgetary allocations are not optimally utilised.

The Department of External Resources of the Ministry of Finance coordinates overseas training of the public service. It is basically on the time frame of 'Technical Assistance Programmes' of various donors, and as such is supply-driven. Annually, around 700 public officials get both short-term and long-term foreign exposure through this programme. A lack of a proper overseas HRD planning, high volatility 
of transfers in the public service and lack of importance given for overseas training, lack of initiatives for demand-driven overseas programmes due to insufficient budgetary allocations, lack of proper placement on the job relating to the training obtained, and lack of performance evaluation after training and time constraints for the selection of candidates for some programmes are major drawbacks.

Furthermore, the present process of selection of candidates for overseas training are ad hoc, and unequally distributed (more opportunities for centre than provinces). Thus, some public officers do not get any opportunity for overseas training for their entire career while a few enjoy many opportunities regularly (personal observation). The National Council for Administration (2006) also emphasised this situation and mentioned that "there should be a fair and equitable distribution of such training opportunities".

In summation, these are the key problems this study identified in the personnel management functions of the SLPS: lack of a properly constituted NPSC; delays in making decisions by the NPSC; inadequate manpower planning; lack of firm policies on human resources management functions; centralised recruitment to core managerial groups; ad hoc appointments without required qualifications; excessive recruitment; direct political control over the appointments of Secretaries of Ministries and Heads of Departments; underutilisation of human resources; low salaries of higher positions; lack of authority to the immediate organisation on personnel management aspects of the employee; high frequency of transfers; lack of a proper performance management and performance-based promotion system; lack of properly planned training aiming at specialisation and professionalism; inadequacy of financial assistance for training, and lack of trained trainers; and sporadic political intervention in public personnel management. These issues have negative impacts on public administration. 


\subsection{Part III: Other Critical Issues}

\subsubsection{Corruption}

During the fifty-five years of the independence period, Sri Lanka has experienced an expansion of the levels of corruption in public life...the public perception is that corruption is endemic in the political and administrative sectors of the government. Almost all activities related to the delivery of public goods and services are affected by varying levels of corruption, for example, the obtaining a driver license, the payment of poor relief, the expediting of processing in regard to most services, the awarding of contract, and processes of procurement and payments for supplies of goods and services (ADB, 2004b, p.22).

Corruption is not only institutionalised in the service delivery but it is also embedded in other areas, such as revenue collection, and privatisation processes. The recent reports by the AG (2006, $2007 \& 2008)$, COPE (2007 \& 2008) and COPA (2007) highlight many irregularities in public institutions and the privatisation process. COPE and COPA found that corruption and malpractices had risen to a high level in many government institutions.

The following section illustrates COPE findings on the Board of Investment (BOI), Ceylon Electricity Board (CEB) and the COPA finding on the Value Added Tax (VAT) fraud in the Inland Revenue Department (IRD) to point out the widespread nature and magnitude of corruption in the SLPS. COPE findings on privatisation will be discussed in Chapter 5.

The BOI is the autonomous government body functioning under the President to promote foreign investment in the country. In carrying out its functions it has the power to grant to eligible companies specific incentives, such as tax holidays or preferential tax rates, exemption from customs duty and foreign exchange controls, which remain valid for the life of the enterprise. In regard to the BOI, the COPE report highlighted that the loans given for the BOI projects have been misused and thereby the BOI abused its authority. BOI officials failed to even provide statistics about imports and exports under the BOI banner. It was pointed out that companies registered in the BOI had imported Yellow Corn and Soya beans on the pretext of animal feed and siphoned them to the open market for human consumption over a 
long period of time. In addition, BOI had entered into an agreement with an Indian company by giving extraordinary concessions, such as reimbursing tariff increases by CEB, and also customs duty paid to the Indian Government. The COPE report stated that BOI is not organised properly, thus it carries out important tasks in an ad hoc manner which leads to malpractices.

Another example of corrupt practices comes from CEB. CEB is the state-owned enterprise having monopoly for generation, transmission and distribution of electricity in the country. In regard to the CEB, the COPE report (2007) has pointed out that its Board of Directors is weak, and has been dictated to by the bureaucrats and Trade Unions on many occasions. As a result, corruption and malpractices have increased. However, the Board of Directors was later dissolved. The Deputy General Manager of the CEB was found guilty of serious charges and recommended for dismissal but this recommendation was not forwarded to the Board of Directors for necessary action by the former General Manager. Later this officer was appointed as the Head of the Tender Board. There were 74 officials who were charged with offences at the time of the COPE investigation. Furthermore, COPE found that the internal audit division had been weakened to prevent the disclosure of corruption and misappropriation, and the internal auditor pointed out that she cannot work due to non-submission of relevant documents to her. It was found that electricity meters and light posts were purchased without adhering to the tender procedures. Due to corruption, malpractices and inefficiency, the CEB lost SLRs 15 billion in 2007.

According to the Chair of COPE, as a result of inefficiency and corruption of the public institution, SL may have lost in excess of SLRs 100 billion (one billion dollars) for the year 2006 alone. The loss is about a fifth of government revenue (Daily Mirror, 2007, January 20).

The parliamentary watchdog COPA which examines the accounts of public sector institutions other than public enterprises, investigated a multi-billion rupee fraud in 2005 on VAT Refunds in the IRD. This is the largest fraud investigated in the history of SL. However, it is revealed that the IRD detected the fraud long before the AG revealed it in June 2005, but took no action. Failure to take proper action allowed it to continue. Accordingly, the IRD wrongfully refunded VAT to the amount of SLRs 
3.648 billion during the period from October 1, 2003 to August 15, 2004 under one Commissioner General and, subsequently the AG brought to notice another SLRs 0.274 billion fraudulent refund from November 15, 2002 to September 30, 2003 under the next Commissioner General (COPA, 2007). The COPA noted that a Departmental Inquiry had not been initiated, pertaining to the issues raised by the AG despite the magnitude of the fraud.

It was also revealed that the IRD's computer system had been manipulated to the extent that two VAT assessments amounting to SLRs. 200.6 billion issued by the department could not be viewed through the computer screen for control and audit purposes. Further, it was revealed that under the GST (Goods and Services Tax) system which was in place during 1998 to July 2002, a similar fraudulent refund amounting to SLRs 114.6 million had also been made. Another remarkable observation was that there was a heavy accumulation of tax in arrears during the last few years. Accordingly, tax in arrears at the end of 2000 was SLRs 22.4 billion (19\% of the total collection for that year), which increased to SLRs 67.3 billion at the end of 2003 and consequently to SLRs 157.6 billion at the end of 2006 (62\% of the total collection for that year). In addition, COPA (2007) highlighted that documents relevant to 183 out of the 235 refunds were not made available for investigation and this was brought to the notice of the Accounting Officer (Head of IRD) and the Chief Accounting Officer (Secretary to the Treasury), but no action had been taken either to report to the police or to the AG.

It is interesting to note that the then Head of the IRD, having carried out an initial investigation, reported to the Secretary to the Treasury in September 2005 that the issue of refunds is a collective activity of a number of officers and it is not possible to identify and single out any individual as being responsible. This provides an interesting point in public policy in the SL context, i.e. the lack of an accountability mechanism in place to hold an individual officer responsible for the tasks he or she does, especially in such an important department in the public sector.

There are several reasons for this sad situation for which both UNP-led and SLFP-led governments and bureaucrats at the high echelons were and are equally responsible. Firstly, public institutions have been politicised over decades. Secondly, due to the 
politicisation they have been mismanaged by politically-appointed personnel, particularly the public corporations and statutory boards. Thirdly, there is a lack of proper systems and procedures, lack of discipline, lack of seriousness and commitment in combating corruption, and lack of utilisation of secured IT, for example, in the IRD. Fourthly, there are many layers in the administrative hierarchy with varying degrees of authority, so there are many opportunities for malpractice. Fifthly, there is a lack of supervision by the heads of departments and the secretaries of ministries. Lastly, there is a lack of clear demarcation of responsibility and, in turn, accountability mechanisms in public organisations.

It is also worth noting that all these corrupt practices are taking place in a country with the availability of anti-corruption institutional measures. The Bribery and Corruption Commission was established in 1994, under the President, by the SLFP government, criticising the previous UNP-led government for corruption over a 17year reign (1977-1994). However, over the years bribery and corruption have increased in public life. The Annual Reports 2005/6 \& 2007 of the Bribery and Corruption Commission show this situation.

\section{Table 4: Number of Complaints Received by the Bribery and Corruption Commission from 2000-2007}

$\begin{array}{cc}\text { Year } & \text { No. of Complaints } \\ 2000 & 975 \\ 2001 & 1716 \\ 2002 & 2052 \\ 2003 & 1803 \\ 2004 & 2285 \\ 2005 & 2118 \\ 2006 & 4267 \\ 2007 & 3985\end{array}$

Source: Commission to Investigate Allegations of Bribery or Corruption, Annual Reports 2005, 2006 \& 2007 
Accordingly, over the eight-year-period of, 2000-2007, the number of complaints received by the Commission is significant. Year 2006 shows an increase of $101 \%$ over the previous year. It was the highest number of complaints received by the Commission since its establishment. However, it has failed to prosecute and punish a single significant case. People have no faith in the Commission. It has been highly criticised casting the net not for 'sharks' but for 'sprats' (kind of small fish). In fact, it has no teeth. The Commission itself cannot initiate prosecution on probes without complaint from a person. There is no protection for whistleblowers.

Although the Commission has been established with great interest and good faith, no President wants it to function effectively. The Commission was paralysed during the period from December 14, 2004 to March 29, 2005 due to the President's failure to appoint Commissioners (Commission to Investigate Allegations of Bribery and Corruption, 2005). Under the present President, the Director General (DG) of the Commission was transferred to the Presidential Secretariat in February 2008 and an Officer of the Assets Investigation Division was transferred out, while he was investigating a former minister's assets and the assets of several other politicians and higher echelon bureaucrats under the Declaration of Assets and Liabilities Law, No 1 of 1975 ("President removes", 2008).

According to the DG, the Commission lacks a permanent cadre for investigations. The investigations are carried out by officials of the Police Department who are seconded to the Commission. This situation is a bottleneck for its effective operation (Interview, 28.01.2008).

In an attempt to rectify these concerns, in 2006, the current government established a Special Presidential Commission chaired by a retired High Court judge to probe the 2005 VAT scam. The investigations are still underway.

\subsubsection{Issues in Systems and Procedures}

The volume of correspondence of the government institutions has increased largely due to the expansion of the public sector in all aspects of the economy. A delay in dealing with this correspondence is reported daily in the media and has been a cause 
for considerable irritation to the public which led to public dissatisfaction of the public service over some time (ADB, 2004b; ARC, 1986/88). This is mainly due to the breakdown in the office systems in most departments and statutory bodies. The majority of the effective systems adopted in the past such as case registers, filing systems, and call-up diaries are not used by the public officials in most of the organisations. The lack of proper systems and procedures, the use of outdated forms without commensurate modification to meet modern-day needs and complicated work processes in the public service delivery mechanisms have led to malpractice and corruption and low productivity. The ARC of 1986/88 (Report No. 10, p. 1) pointed out:

The defects in the work systems and procedures affect productivity, cause unnecessary inconvenience to the public and lead to overstaffing. ...system improvement is an area to which serious attention should be paid.

Although the ARC's recommendations on system improvement were not given due consideration at that time, a considerable priority has now been given by the National Administrative Reforms Council (NARC) ${ }^{36}$. This council was established in 2003 under the Prime Minister, and it was reconstituted in 2004 with the change of government. This Council is now operating under the President and is chaired by the Secretary to the President. It is composed of 13 members in total including several Secretaries of Ministries, a few academics, former senior public officials and a senior representative of the private sector.

The NARC focuses on the flowing reforms:

Re-examination and rationalisation of work content of government agencies;

Re-engineering the business of government;

Human resources development; and creation of a working environment conducive to continuing productivity enhancement

Dhammike Amarasinghe, Advisor to the President, commented on NARC involvement:

In an exercise carried out under the aegis of the ARC predecessor to NARC in 2005 quite a number of ministries and departments reviewed their functions and to a certain extent they identified functions to be dropped, added and things to be done in different ways, but

\footnotetext{
${ }^{36}$ The Gazette of the Democratic Socialist Republic of Sri Lanka, No. 1499/20, July 30, 2007.
} 
that was not in many instances. Some ministries did not do so. We have to get them also into this process. A large number of ministries were involved in the system improvement programme. They improved some aspects. Systems and procedures in all agencies have to be reviewed and there should be continuous improvements. ....We try to follow the recommendations of the ARC, 1986/88, because they are still valid. The council has appointed the Secretary to the Ministry of Public Administration as the DG of the Administrative Reforms Council (Interview, 10.12. 2007).

In addition, steps have been taken to transform several service delivery systems by using IT which was discussed before. The application of IT in service delivery has a greater effect on improving service delivery at present.

There are also deficiencies in relation to the decision-making structure in the public service. There is a long chain of hierarchical layers as depicted in Figure 6 below on matters related to administration.

\section{Figure 6: Typical Hierarchy of Current Decision-Making in a Ministry}

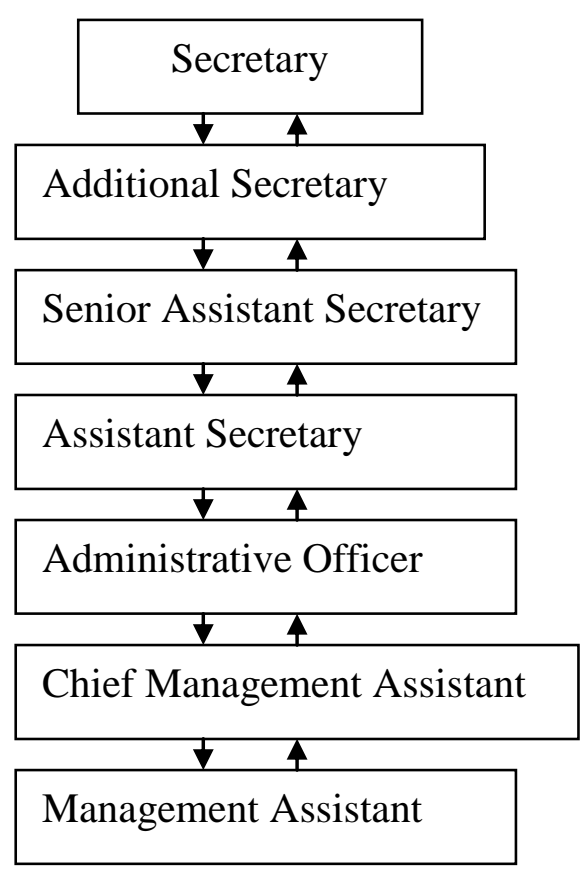

The lack of delegation of authority to lower levels on matters in regard to routine services has contributed to considerable delays in attending to the needs of clients. Moreover, it consumes extra manpower which means extra costs. In addition, this contributes to the ineffective use of staff at executive level. 
The other deficiency in the system and procedures is the lack of management information systems in the public organisations. This affects negatively the quality of decisions in the public sector and trustworthiness of government data. This is evident in the previous discussion about data of the Central Bank and the other governmental organisations which were not compatible. In addition, there is a lack of management culture to disseminate information through e-mail. Letter writing is the most common mode of communication in the public sector, even within institutions, resulting in delays.

Another deficiency in the work system and procedure is the lack of management culture to issue a job description to public officials. The result is lack of clear ideas about what to do and what is his/her responsibility and inability to hold the official accountable. This deficiency was apparent in the recent reply to the AG by the Commissioner General Inland Revenue Department, "he has not come to know that there had been any arrangement to issue Duty Lists to officers of the Inland Revenue Service from the very inception, either in giving the letters of appointments to them or in making promotions. However, once they are assigned to the respective divisions by the Commissioner General, administration and other relevant functions of the division concerned should be performed by them. In addition, the duties to be performed by them are mentioned in various Acts and tax procedure manuals relating to the department" (Auditor General, 2006, p.50).

\subsubsection{Trade Unionism}

The SL Constitution ensures freedom of association. Every citizen is entitled to the freedom to form and join a trade union. SL currently has 1500 registered trade unions. Unionisation is around $12-15 \%$ of the total workforce. These employee unions are generally organised by employees into a single service. Furthermore, in a single service there are many different trade unions. In the health and railway services there are over 50 unions (Daily Mirror, 2007, December 30), thus unity in a particular occupation appears to be remote. The majority of the unions ally with major political parties, thus, they have become mere components of the major political parties; for example, the leaders of trade unions are selected by the political parties concerned so those unions are not able to produce leaders within their own 
rank. However, there are independent trade unions too, for example, Government Medical Officers Association.

The law grants workers the right to strike. Accordingly, strikes are more common in SL. These unions do strike only for better employment conditions, but mostly for political reasons and against public policy matters such as privatisation, restructuring and reforms. Many attempted reforms were resisted by trade unions on several occasions; for example, in 2003, they resisted the establishment of a Revenue Authority by amalgamating three existing revenue departments: the Customs, Inland Revenue, and the Excise. In 2004, the Railway Department was reformed and established as the Railway Authority. Due to strong resistance of trade unions the government restored the status quo once again. Currently trade unions are consulted in the formulation of the annual transfer schemes in the public service.

\subsubsection{Financial Management}

According to Article 148 of the Constitution (1978), Parliament is supreme in relation to matters of public finance. It says:

Parliament shall have full control over public finance, no tax, rate or any other levy shall be imposed by any local authority or any other public authority except by or under the authority of a law passed by Parliament or of any existing law.

Within Parliament, the financial initiatives and executive authority lie with the Cabinet, and only a Cabinet Minister has power to propose a "money bill" such as the Annual Appropriation Bill. The Cabinet has delegated this authority to the Minister of Finance. Parliament retains the power of approval, amendment and rejection of proposals, while the executive (Cabinet) is responsible for the implementation of the annual financial plan (revenue and expenditure) of the government. Each Secretary of Ministry acts as the Chief Accounting Officer and each Head of Department acts as Accounting Officer in regard to public funds.

The public financial operation is facilitated by the "Consolidated Fund" created under an Order in Council of 1946 and carried over under subsequent Constitutions. All revenue not allocated by law to any specific purpose are paid into this fund and any expenditure deemed appropriate by the Parliament may be met from it. 
Nevertheless, money cannot be withdrawn from this fund except on the authority of a warrant signed by the Minister of Finance ("The Constitution of Sri Lanka, 1978").

The framework of financial management is based on the Financial Regulations (FRs) which come from the colonial regime and Finance Act No. 38 of 1971. The FRs deal with all aspects of procedures and controls necessary for authorising, approving, executing (procuring), recording and reporting government expenditure. The Public Expenditure Management System Project in 2003 has identified some weaknesses in these regulations and concluded that "problems with FRs ranged from complete absence of controls in some areas, to irrelevant control in others" (World Bank, 2003, p.15). Further, circulars are issued by the Treasury on occasion on the authority of the Finance Minister to secure uniformity and fairness in public financial management, especially in budget formulation and implementation.

As explained in the previous sections of this chapter, especially under the headings of Public Enterprises, Fiscal Decentralisation to PCs, and Corruption, it is evident that there are weaknesses in the present financial management system. They also demonstrate the lack of financial accountability both at the centre and provinces and the use of public funds without due care for intended purposes, the economy and efficiency. In addition, the everlasting budget deficit (an average of $8 \%$ annually), contraction in the economy (4\% in 2002), high amount of public debt (105\% of GDP in 2002), high amounts of interest payment of government debt (peaked at $7.5 \%$ of GDP in 2003), and increased off-budget expenditure (US\$ 457 million in 2000) shows the ad hoc nature of handling public finance in the country over time (ADB, 2004b, 2008; Central Bank, 2006; Ministry of Finance and Planning, 2007). Against this backdrop, a prudent financial management system is essential to promote economic growth and its sustainability.

The Fiscal Management Reform Programme (FMRP), which will be discussed in detail in next chapter, was launched in 2003 under the financial assistance from the ADB. Under this programme the Fiscal Management (Responsibility) Act No.3 of 2003 was enacted. 


\subsubsection{Fiscal Management (Responsibility) Act of 2003}

The main objective of the Fiscal Management (Responsibility) Act is establishing fiscal discipline and reporting. In this context, the Act requires the Minister of Finance to account to Parliament and to the public, in five stages, its record in the management of the public economy: fiscal strategy statement, mid-year fiscal position report, final budgetary position report, pre-election budgetary position report, and statement of responsibility. Table 5 gives details.

\section{Table 5: Reporting (Responsibility) Act of 2003

\begin{tabular}{|c|c|}
\hline Name of report & $\begin{array}{c}\text { Date of } \\
\text { submission }\end{array}$ \\
\hline Fiscal Strategy & With the \\
\hline $\begin{array}{l}\text { Statement } \\
\text { (Section 4.2) }\end{array}$ & $\begin{array}{l}\text { budget speech } \\
\text { (second } \\
\text { reading) }\end{array}$ \\
\hline
\end{tabular}

Mid-year Fiscal position Report (Section 10)

Final

Budgetary Position Report (Section 13)

$\begin{array}{ll}\begin{array}{l}\text { Pre-election } \\ \text { Budgetary }\end{array} & \begin{array}{l}\text { Within } 3 \text { weeks } \\ \text { of the } \\ \text { Position Report } \\ \text { announcement } \\ \text { of a general } \\ \text { election 16) }\end{array} \\ \begin{array}{l}\text { Wtatements of } \\ \text { Responsibility. }\end{array} & \begin{array}{l}\text { With the pre- } \\ \text { election } \\ \text { budgetary }\end{array} \\ & \begin{array}{l}\text { rection 19) } \\ \text { report }\end{array}\end{array}$

End June or lapse of 6 months from the date of the passing of the Appropriation Act, whichever is later End May of the year following the budget
Government's medium-term fiscal policy,

Broad strategic priorities on which the budget is based,

Key fiscal measures relevant for the implementation of the fiscal strategy, Fiscal objectives and targets related to fiscal indicators, especially government debt.

Estimated and actual expenditure, revenue, and cash flow for the first months of the year.

Estimated and actual government borrowing, and any other statements reflecting the Government's financial position for the first 4 months of the year.

Estimated and actual expenditure, revenue, and cash flow for the year. Estimated and actual government borrowing, and any other statement reflecting the Government's financial position during the year.

Reasons for shortfalls in the estimated revenue and overruns in expenditure and borrowings.

Estimates of revenue and expenditure and economic and other assumptions used for these estimates.

Statement signed by the Minister to the effect that the Minister has disclosed all the known information required for the preparation of the pre-election budgetary report, within one week of an announcement of an election. Statement by the Secretary stating that the preelection report contains information to the fullest extent possible.
Fiscal Management

Objectives

Increasing public awareness and establishing standards for evaluating the Government's conduct of fiscal policy

Providing updated information on the Government's fiscal performance in the first 4 months to enable the public to evaluate it with the government's fiscal strategy.

Providing updated information on the Government's fiscal performance for the whole year to enable the public to evaluate it with the Government's fiscal strategy.

Announcing the current fiscal position of the government to the public to avoid election handouts.

Stating the responsibilities of the Minister and the Secretary in preparing the pre-election budgetary report. 
In addition, the Act stipulated targets for the overall budget deficit to 5\% of GDP and the public debt to $85 \%$ of GDP by the end of 2006. Accordingly, from the date that the Act came into effect, successive Ministers of Finance have fulfilled the reporting requirements, but they could not achieve expected financial targets as stipulated. Instead, the government which came into power in 2004 revised these targets after the Tsunami Disaster. Accordingly, "budget deficit is estimated to decline to $7.7 \%$ of GDP in 2007 from $8.1 \%$ in 2006 and $8.7 \%$ in 2005" (ADB, 2008, p. 40). However, the Fiscal Strategy Statement 2006 issued by the Minister of Finance and Planning, has reported that these targets would be possible by the year 2008 .

The trend of these financial progress indicators has been unsatisfactory. The budget deficit has remained over 8\% of the GDP from 2003-2007 (2003, 8.0, 2004, 8.2, 2005, 8.7, 2006, 8.4 and 2007, 8.8). However, the budget deficit had dropped from 8.8 (2007) to 7.7\% of GDP in 2008 (Ministry of Finance and Planning 2008). Public debt has also been reduced marginally up to 2007 (2002, 105; 2003, 105.9; 2004, $105.4 ; 2005,93.9 ; 2006,93,2007,85.8$ ) (ADB, 2008; Ministry of Finance and Planning, $2006 \&$ 2008). Public debt was further reduced to $81.1 \%$ of GDP in 2008 but it increased to $86.2 \%$ in 2009 (Central Bank, 2009). Accordingly the level of budget deficit as well as public debt could not be achieved as expected by the Fiscal Responsibility Act. The Figure 7 shows the trend of fiscal deficit and the public debt position of the government. 
Figure 7: The Trends of Budget Deficits and Public Debt (\% GDP) from 20032009

Budget Deficit

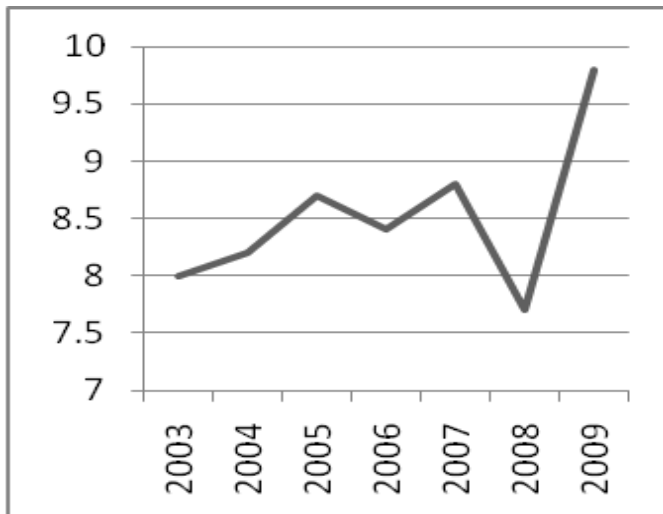

Public Debt

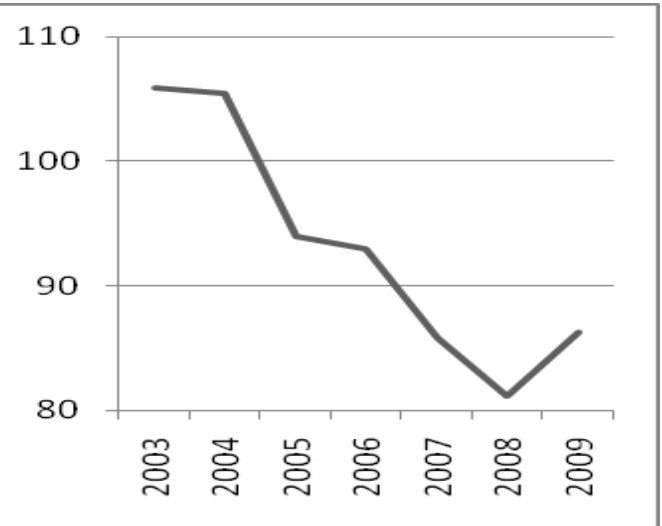

Source: Ministry of Finance and Planning, 2009

The main reason for non-achievement of targets might be deficiencies in public expenditure and revenue management. Nevertheless, this legal requirement paves the way for greater transparency of the economic management and fiscal policy of the government. It also has opened the door for the public and the private sector to access such vital information to assess the government's fiscal position and to make decisions. However, so far neither Parliament nor the public has pressured the Finance Minister to achieve the targets. The following section discusses the revenue management of the government followed by the expenditure management.

\subsubsection{Revenue Management}

Government revenue is mainly managed by four departments: the Customs, Inland Revenue, Excise, and Motor Traffic. The major shortcomings of the revenue collection of the IRD have already been discussed under corruption in this chapter. In the case of Customs, which is the second most important department, revenue collection has shown several shortcomings: system weaknesses such as irregularity in budgeting, and non-compliance with statutory and regulatory requirements (Auditor General, 2006). However, there was no such major adverse comment by the AG in regard to the revenue management of the Department of Excise in 2006. In contrast, revenue management of the Department of Motor Traffic has shown many 
deficiencies: poor budgeting (in 1998 budgeted revenue was SLRs 1275 million and the actual was SLRs 752 million, in 2004 budgeted revenue was SLRs 717 million whereas the actual was 1391 million), unsatisfactory maintenance of files (difficulty in tracing files when needed) and malpractices in vehicle registration. In regard to vehicle registration, the AG pointed out that motor 'trucks' had been registered as 'cars' by making use of forged customs documents and licences had been issued without proper check. He further says,

This had been happening since 2004 and continuously pointed out in audit since 2005 but no effective remedial action had been taken and therefore this practice is continuing in a substantially large scale despite the fact this has been one of the root causes for most of the irregularities in the system including that of in the Department of Customs, resulting huge revenue losses (Auditor General, 2006, p.54).

This shows that internal control is lacking in these institutions and there is indiscipline. Furthermore, the AG has reported that there is no proper database on revenue collection, thus the figures appearing in the revenue accounts of the IRD, government financial statements and the annual report of the Central Bank are different. Table 6 shows the discrepancy in revenue figures of the government.

Table 6: Revenue Figures of IRD, Government Financial Statements and Annual Reports of the Central Bank

\begin{tabular}{|c|c|c|c|c|}
\hline \multirow[t]{4}{*}{ Year } & \multirow[t]{4}{*}{ Tax category } & Revenue & Government & As per Annual \\
\hline & & Accounts of the & Financial & Report of the \\
\hline & & IRD (SLRs mn) & Accounts & Central \\
\hline & & & (SLRs mn) & Bank(SLRs mn) \\
\hline \multirow[t]{2}{*}{2003} & Income Tax & 38,602 & 38,783 & 39,397 \\
\hline & Value Added Tax & 97,754 & 97,754 & 97,230 \\
\hline \multirow[t]{2}{*}{2004} & Income Tax & 41,956 & 41,372 & 41,372 \\
\hline & Value Added Tax & 117,032 & 117,032 & 120,382 \\
\hline \multirow[t]{2}{*}{2005} & Income Tax & 49,438 & 52,536 & 52,536 \\
\hline & Value Added Tax & 141,878 & 141,887 & 138,660 \\
\hline \multirow[t]{2}{*}{2006} & Income Tax & 80,334 & 77,707 & 80,483 \\
\hline & Value Added Tax & 164,071 & 164,277 & 164,555 \\
\hline
\end{tabular}

Source: Auditor General, 2006, p. 49 
Accordingly, this shows that there is a necessity for a proper information management system to maintain high quality data integrity and accurate information for policy makers and other stakeholders. There is a lack of coordination in these institutions in finalising their reports. It is reiterated that the Central Bank figures in relation to public sector employment also differ from that of the Census and Statistics.

\subsubsection{Public Expenditure Management}

An effective public expenditure management system needs to operate at three levels: at the macro level to ensure overall aggregate fiscal discipline, at the mid-level to ensure the overall allocations match strategic priorities and at the micro level to ensure that resources are effectively allocated to produce the desired results. At the overall macro level of aggregate fiscal discipline, it is important that what is spent matches what is affordable and sustainable over the medium term. In this aspect the fiscal position of SL currently is barely sustainable (ADB, 2008, p. 13). As explained earlier, the budget deficit remains an average 8\% of the GDP until 2007 and in 2008 it was 7.7 well short of the fiscal target spelt out in the Fiscal Management (Responsibility) Act. However, the percentage of public debt/GDP declined from $105.9 \%$ in 2002 down to $81.1 \%$ in 2008 and again increased to $86.2 \%$ in 2009 .

At the mid-level, priorities of government expenditure are currently on national security, debt servicing, humanitarian relief, pension and wages and salaries. Wages and salaries have increased by $26.4 \%$ per annum on average from 2006-2009. This is mainly because of massive recruitments, salary increases and the introduction of new allowances (ADB, 2008). The total interest and repayment of public debt as a percentage of total expenditure was 41.6 in 2006 (Auditor General, 2006). Further, the total debt service payments as a per cent of GDP increased to 17.1 from 13.4 per cent in 2008 (Central Bank, 2009, p.143). Therefore, debt servicing is a critical factor in budget management. The debt situation was further exacerbated in 2009 when total outstanding government debt increased by $16 \%$ to SLRs. 4161.4 billion as at end 2009 compared to SLRs. 3589 billion as at end 2008 (Central Bank, 2009, p. 140). The total outstanding foreign debt increased by $22 \%$ in 2009 . As a percentage of GDP, foreign debt increased to $36.5 \%$ by end 2009 as against $32.8 \%$ in 2008 . 
Despite the fact that the SL economy depends on domestic and foreign debt for its survival, there is a lack of attention to handle this critical factor systematically. Currently, there is no proper institutional arrangement with skilled personnel to handle debt management, or at least in its coordination. The public debt functions are dispersed among three separate organisations: the Central Bank (CBSL), External Resources Department (ERD), and Treasury Operations Department (TOD).

The CBSL has been given the responsibility of managing the public debt of the government under the Monetary Law. Accordingly, the Public Debt Department of the CBSL undertakes issuance of domestic debt in line with the Appropriation Act and servicing of both domestic and foreign debts. The ERD is responsible for negotiating and mobilising foreign debt to finance the budget deficit in term of concessionary and commercial borrowings and grants. It is also responsible to ensure the effective utilisation of foreign financing. However, it lacks skilled professionals in debt management. The TOD is responsible for cash management and accounting of debt transactions.

There are two major weaknesses in the system due to disperse nature of debt handling. Firstly, there is no aggregate database regarding public debt. Secondly, there is no systematic risk analysis to determine the effects of variations of exchange rates, interest rates or debt sustainability analysis when raising the debt (Project Team for Establishment of a Public Debt Management Office, 2004). Therefore, as indicated by the $\mathrm{AG}$, the portfolio of public debt shows imbalance, which clearly shows that there is no proper evaluation of risks and cost effectiveness in selecting debt markets, foreign or domestic; rather they are mobilised in an ad hoc manner according to exigencies. In 2006, the government went for commercial borrowings at higher interest rates through HSBC, and National Savings Bank despite the existing scenario.

However, the UNP government which introduced Fiscal Management Responsibility Act has realised the need for effective debt management system and established a "Public Debt Management Project Office" in August, 2003, in the Treasury with four officials. These officials studied the existing debt management system, the laws relating to public debt functions and helped the Commonwealth consultants to 
establish an Independent Debt Management Office in SL. However, this project office was dismantled with the change of the government in 2004.

The other factor in expenditure management is the unrealistic nature of expenditure budgeting. For example, the total actual expenditure for the year 2006 was SLRs 1,072,782 million and the estimated figure was SLRs $1,177,766$ million with a variance of SLRs. 104,984 million (Auditor General, 2006, p. 56). Similarly, the total capital expenditure difference between the actual and the budgeted figure, excluding the repayment of public debt was SLRs. 79,085 million. This was $28.6 \%$ of the total of the budgeted capital expenditure of 276,935 million for 2006. This shows that the budget estimates are not realistic. This bloated budgetary system leads to further accumulation of public debt, and an increase in the budget deficit leading to inefficiency of financial management of the country. Table 7 shows this position numerically.

Table 7: Capital Budget and its Utilisation in 2006

\section{Description Consolidated fund Foreign funds Total}

(SLRs million) (SLRs million) (SLRs million)

Total provision 261,679

188,493

73,186

$72.0 \%$

$28 \%$
15,256

9,357

5,899

$61.3 \%$

$38.5 \%$
276,935

197,850

79,086

$71.4 \%$

$28.6 \%$

Source: Auditor General, 2006, p.56

According to AG's report for the year 2008 (p. 39), the total estimated expenditure for the year was SLRs. 1580 billion and the utilisation was SLRs. 1413 billion, thus there was a saving of SLRs. 167 billion. The savings rate was $10.5 \%$ which was less remarkable when compared with 2006 figure of $28.6 \%$.

According to the AG, the Chief Accounting Officers have indicated to COPA at the examination of performance of government ministries and departments that inadequate cash provision led to this situation. Therefore, Treasury's cash 
management system is also a matter for concern (Auditor General, 2006). The Ministry of Health Care and Nutrition, and the Ministry of Education, which are the main ministries for improving human capital, have capital expenditure savings of $40 \%$ and $41 \%$ in 2006 respectively (Auditor General, 2006). This further shows unrealistic budget and planning, and under utilisation in the main ministries.

Therefore, the framework for the recurrent and capital expenditure and cash management needs attention for any future reforms in financial management.

\subsection{Conclusion}

This chapter reviewed the current situation of public administration in SL in depth. The analyses were confined to the core areas: the roles and functions, structure and service delivery, cadre position, personnel management, corruption, trade unions, systems and procedures, and financial management. These key areas are critical in measuring the efficacy of the country's public administration. SL's performances in each of these areas are specific to its political, economic and cultural underpinnings and have profound negative implications for its public management.

This chapter noted many deficiencies in all of these areas, including massive corruption and failures in systems and procedures. The current structure suffers from duplication of functions, and confusion due to lack of clear demarcation of roles among different layers. The lack of fiscal, human resources and statutory autonomy in the provincial level hinders efficiency in public administration. Decision-making structures in public administration are costly; consume excessive time in making decisions, and make ineffective use of officials. The current service delivery suffers from lack of proper service delivery mechanisms. The coexistence and use of deconcentrated service delivery structures, along with the provincial set-up and the control of the centre in every aspect of devolved tasks, hinders effective service delivery to citizens. The current bureaucracy is bloated, costly and suffers from low effectiveness and efficiency. It further suffers from low compensation. The ad hoc appointments have weakened the norms and the quality of public service. The recruitment to public services and the proliferation of ministries have gone hand in hand in the recent past dramatically, without even considering the required qualifications. There is a lack of attention to performance management. New public 
enterprises are emerging despite the fact that the majority of the existing enterprises make losses and drain huge sums of money from the budget. There is a lack of performance culture. Outputs or outcomes are not considered in the allocation of funds. Lack of performance culture in the budget hinders the effective utilisation of public funds. The only expectation is spending. The cash management and debt management suffer from ad hoc arrangements in releasing funds and raising debts with unrealistic budget estimation. More importantly, corrupt practices permeating into public administrative functions as a whole are a major issue that need immediate attention. There is no common programme for fighting corruption, wastage of resources and for rationalising expenditure.

These problems have persisted in public administration from at least since 1986. The ARC identified the same problems and made recommendations to remedy them. Only the recommendation for salary increase has been implemented. The failure of timely interventions, together with other socio-economic and political underpinnings which will be discussed in the next chapter, led to the present chaotic situation. 


\section{Chapter 5: Public Sector Reforms in Sri Lanka from 1950- 2005}

\subsection{Introduction}

The origin of the current problems as illustrated in the previous chapter can be found in the recent history of public administration of the country. Therefore, any solutions to solve them must also be founded upon the specifics of this context. This chapter intends to provide an overview of some significant reforms already undertaken in SL and the factors that led to their development and progress. Further, this chapter illustrate a wide range of factors and their complex interaction, which have shaped the system of government. This illustration provides initial justification for assuming that designing the prospects for public sector reform in any country must begin with an understanding of the society itself and its history.

I stopped the historical review at 2005. Since my interest was the historical context of previous attempts at reform, especially the ARC, choosing 2005 allowed me enough time for review any initiatives in the 1990s and 2000s that followed the wide-ranging ARC agenda to have been implemented and matured. But that does not mean that work on public sector reform in SL is stopped since then. The current initiatives started after 2005 have not had sufficient time to mature, and so historical analysis is not yet warranted.

This chapter gives a brief overview of post-independence administrative reforms in SL and examines the major initiatives of successive governments from 1950 to 2005 in detail. The discussion is organised in chronological order as follows.

Part I: The reforms initiatives during the 1950s and 1960s

Establishing an Organisation and Methods Unit - 1951

Enactment of Language Act- 1956

Creation of branch offices

Setting up public corporations - 1955

Abolition of Ceylon Civil Service and Village Headman system - 1963 
Part II: The reforms initiatives during the 1970s and 1980s

Introduction of Divisional Development Councils -1971

Abolition of the independent Public Service Commission (PSC) - 1972

Establishment of District Political Authorities - 1973

Introduction of Decentralised Budget - 1974

Initiation of District Ministers -1978

Re-establishment of PSC under Cabinet- 1978

Introduction of District Development Councils - 1980

Privatisation of Public Enterprises - 1980

Establishment of Administrative Reforms Committee -1987

Introduction of Provincial Councils - 1988

Introduction of individual performance appraisal system - 1989

Part III: The reforms initiatives during the 1990s and 2000s

Invitation of UNDP mission - 1990

Invitation of ADB team - 1996

Initiation of Financial Management Reforms - 2000

Re-establishment of independent NPSC - 2001

Creation of Management Assistant Service - 2005

\subsection{Part I: The Reforms during the 1950s and 1960s}

During the 1950s and 1960s, at the highest level, reform efforts were establishing the Organisation and Methods Unit and public enterprises, introduction of the Language Act of 1956, abolition of the Ceylon Civil Service and creation of a unified Administrative Service. At the middle level, departments were decentralised and brought under the coordinative role of the GA at the district level, and at the bottom, the Village Headman System was abolished in 1963. As a consequence, the year 1963 started a new era in the public sector. The following sections will examine these reforms in detail. 


\subsubsection{Introduction of $O$ and $M$ Approach to Administration}

The first attempt at reforms took place in 1951 in order to improve the efficiency of the public service when the UNP Government was in office. A team from the U.K. Treasury was invited to advise on implementing the organisation and methods $(\mathrm{O}$ and $\mathrm{M}$ ) approach to efficient administration, a world-wide phenomenon during that time, and the recruiting and training of $\mathrm{O}$ and $\mathrm{M}$ staff. They recommended establishing an $\mathrm{O}$ and $\mathrm{M}$ unit on the British pattern in the Treasury (Nadarajah, 1997).

The Government accepted their report, and an $\mathrm{O}$ and $\mathrm{M}$ unit was established in the Treasury the same year. The main responsibility of the unit was to investigate the organisational and operational methods of government departments and advise on their improvements. In this respect its sole function was of an advisory nature. However, it appeared that this effort failed soon after it was implemented due to lack of both political will and senior Treasury bureaucrats' support (Nadarajah, 1997). The main reason for this failure was partly justified by the fact that many of the Treasury senior officials who were entrusted with $\mathrm{O}$ and $\mathrm{M}$ functions were busy with immediate and demanding responsibilities. In addition, this reform lacked comprehensiveness to gain momentum across the public service.

\subsubsection{The Language Act No 33 of 1956}

Language has been a socio-political issue in SL since Independence. Thus, the second attempt at reforming the aspects of public administration was the introduction of the Official Language Act in 1956. In fact, until today this reform has had more far-reaching effects on public administration than any other reform, thus warranting discussion here.

During the British period (1796 -1947) English was the official language in the country. Knowledge of English was essential to get into the public service, even after Independence. The Tamils in the North and East had acquired English education early through missionary education and obtained Government posts in relatively 
large numbers (De Silva, 1993; Kearney, 1996; Warnapala, 1974). The majority of the population of SL (then Ceylon) was and still is Sinhalese (78\%) and most of these people were educated in Sinhalese because, under the Donoughmore Constitution of 1931, vernacular education in Sinhalese expanded rapidly, producing a literacy rate of $65 \%$ in 1953 . However, few opportunities were available in the public service for those vernacular-educated Sinhalese. They found that they were under-represented in the public sector in comparison to the Tamils (Kearney, 1966). Furthermore, they missed opportunities in higher education, unlike the Tamils. The ordinary public throughout the country had to rely on 'petition writers' (it was a somewhat lucrative business) to communicate with the government. The government officials, mostly British, communicated with the public with the aid of interpreters, the majority being clerks of their offices. The courts did the same, so that "the destiny of a non-English speaking accused was dependent upon a group of people who spoke an alien language" $" 37$ (Gunasena, 2006, p. 232).

Under these circumstances several attempts were made by local political leaders in the Select Committee of the State Council:

Ronnie De Mel, former Finance Minister (1977-1988), in an interview said,

Earlier in the 1940s before independence Mr. J.R. Jayewardene had brought forward a motion in the State Council that the language should be Sinhala as the main language of the country. But nothing happened although the motion had been passed. The movement for language reform had gathered momentum after S.W.R.D. Bandaranaike broke away from the UNP in 1951. After 1952 the movement came from the people. It was led by number of national movements particularly speared by the Buddhist clergy. The Buddhist clergy had formed two very powerful organisations. One was Eksath Bikkuhu Peramuna and the other one was the SL Sangha Sabha. These two movements were supported by strong organisations of Sinhala Nationalists led by people like Mr. Philip Gunawardena, Mr. L.H. Meththananda and various others. All these forces combined after 1954 to bring down the UNP and to support Mr. S. W. R. D. Bandaranaike with the express promise that there would be an immediate shift to the Sinhala language as the language of the administration of the land. The primary motivation for reform was based on the argument that it was no longer correct for an independent country to have the language of the imperial conqueror, the English, as the language of administration in the land (Interview, 05.12. 2007).

In this sense people thought that the language of administration should be the language of the people in the country, but Sinhala was not the only language that

\footnotetext{
${ }^{37}$ This problem was dramatically articulated by Leonard Wolf in his novel Village in the Jungle.
} 
prevailed in the country. This was clarified by the former Secretary to the Treasury, N. Pathmanathan, in an interview,

Originally J.R.Jayawardene proposed the motion "Sinhala the official language." Then Tamil V. Nalliah, member for Kalkuda, Batticaloa, proposed an amendment saying "Sinhala and Tamil to be the official languages". It was accepted but there was no further development (Interview, 26.11.2007).

This stalemate gave S.W.R.D Bandaranaike an excellent opportunity to gain power. He established a new political party, Mahajana Eksath Peramuna.

Bradman Weerakoon, former Secretary to the Prime Minister (1956-1970, 2001-4), commented,

The first government of Independent Ceylon was that of UNP, which continued in the style of the British. The structure was the same. Mr. Bandaranaike saw the opportunity for rapid change. The language issue was a powerful emotional one. Sinhala only as the official language rather than the two languages was his way to electoral power. He mobilised all classes, sangha (Buddhist priests), teachers, peasants, Ayurvedic physicians, and labourers (Pancha Maha Balavegaya- five power groups) (Interview, 15.11.2007).

Bandaranaike emphasised that "over ninety percent of the [government] jobs of the country are restricted to ten percent of the people who know English. In this land of ours, those ignorant of English are capable of obtaining much less (sic) than ten percent of government jobs" (Kearney, 1966, p. 513). During the election campaign in 1956 he promised to change the language from English to Sinhalese in 24 hours if he was elected. He gained a landslide victory and immediately fulfilled his promise by introducing the "Official Language Act No 33 of 1956", which declared 'Sinhala' to be the sole official language of the country.

This reform brought about a radical social transformation and, thereby, great problems to the bureaucracy and the country. A few Parliamentarians saw this, but the reformers did not. Dr. Colvin R. de Silva, at the debate of the Bill said:

Do you want two languages and one nation or one language and two nations? (Rupasinghe, 2007, p. A9).

He foresaw the future division of the people. J.R. Jayewardene who demanded a Sinhala policy in 1944 was also now critical:

No government should and could make the Sinhalese the official language by trampling down the language rights of over a million of the permanent residents of the country... 
The doors of the public service should not be closed to the thousands of youth who did not know Sinhalese for no fault of their own...surely that was the only way to sow the seeds of civil war (Rupasinghe, 2007, p. A9).

The main problem of this change was that public servants who learned and worked in English now had to work in Sinhalese. This caused considerable tension for a long period. However, public servants were encouraged to learn Sinhala by using incentive bonuses or suspending their annual salary increments until they gained proficiency. According to the Wilmot Perera Report of 1961, five years after the reform a little under half the public servants were able to perform in Sinhalese (as cited in Warnapala, 1974). The public servants, who were recruited before 1956, were given a chance to retire on the grounds that they could not continue working due to the new language policy. As a result, more than three thousand public servants had been selected to retire by mid 1964 under these conditions (Kearney, 1966). According to the Wilmot Perera Report (as cited in Warnapala, 1974, p. 297), the number of officers retired was: 17 in 1956, 256 in 1957, 139 in 1958, and 116 in 1959. Since then the ethnic composition of government employment was changed in favour of the Sinhalese.

The Tamils expressed their discontent over their lack of public employment opportunities and the use of Sinhalese as the official language in governmental administration in the North and East where the majority of them live. The Federal Party which represented the Tamil-speaking communities vehemently influenced the Tamil officials not to learn Sinhalese ${ }^{38}$. They launched a severe satyagraha (agitation) campaign which brought the civil administration to a standstill for more than two months in 1956, and the Government was forced to impose emergency law in Tamil-speaking areas (Kearney, 1966).

Eventually, the Government took a firm decision in 1964. It gave authority to the Ministry of Finance to dismiss any public official who was not proficient in the official language (Warnapala, 1974). However, later public servants were given an

\footnotetext{
${ }^{38}$ C. Vanniasingam, Presidential Address, Ilankai Tamil Arasu Kachchi Annual Convention, 1956 (Jaffna, 1959, p.16), S.M. Rasamanikam, Presidential address at the national convention of the Ilankai Tamil Arasu Kacchchi, 1962 (Colombo, 1962, pp.7-8) and a statement by S.J.V. Chelvanayakam, appearing in Ceylon daily News, May 12, 1962 (as cited in Kearney, 1966, p.516).
} 
additional two years to develop language skills and pass the proficiency examination in Sinhalese. After that, a number of Tamil officials who had failed to fulfil this requirement were served with notices of their compulsory retirement from public service (Kearney, 1966, p. 516). Accordingly, many public servants were disqualified from continuing employment.

In summary, the language reform affected around $25 \%$ of the public service including Tamils, Muslims, and Burghers, but provided easy access to the majority of the Sinhalese to participate in the administration. This created many problems for the Government. The implications of the language reforms will be further elaborated in Chapter 7 due to its importance in the present context.

\subsubsection{Establishing Public Enterprises (PEs)}

The other major reform by the UF government was the establishment of PEs. Many countries around the world emerged from colonial rule wanting ownership and responsibility for the provision of essential goods and services as a part of the natural task of the state. SL was no exception. The PEs became one of the main devices of state involvement in economic development after Independence. The initiative of expansion of the public sector had existed during the previous UNP regime, but was not so vigorous (Warnapala, 1974). It gained momentum only after the 1956 social revolution.

The primary motivation for the establishment of PEs was the willingness to transform the colonial structure and capture the commanding heights of the economy. This policy motivated the nationalisation of many services, such as bus transport, port cargo handling, insurance, petroleum distribution and plantations that had been handled by the European and Indian capitalists (Kelegama, 1992; Warnapala, 1974). This motivation was coupled with great enthusiasm to generate employment for the increasing number of school leavers. In addition, there was a hidden political reason i.e. the UF government taking revenge on its political opponents. For example, one of the reasons for bus transport nationalisation was that the private bus companies had contributed substantial amounts of money to the UNP election fund (Warnapala, 1974). 
Under this reform two important pieces of legislation were introduced: the Government-sponsored Corporation Act No. 19 of 1955 and its revision in 1956, and the State Industrial Corporation Act No. 49 of 1957. The 1955 Act provided for the takeover of existing industries, while the 1957 Act made provision for the establishment of new enterprises. With the new law, all existing corporations were dissolved and re-established under the 1957 Act. By 1964 there were 20 industrial corporations and several others were planned (Warnapala, 1974). Much of the foreign aid received from communist countries was utilised to strengthen these corporations.

According to Warnapala (1974), by 1966 only 15 industrial enterprises were in operation. Some of them operated below the expected capacity for several reasons. One reason was the corporations had been established without proper feasibility studies and cost-benefit analysis. For example, the plant and equipment of the Sugar Corporation had been installed but remained idle until the sugar cane was harvested. A textile factory was located in Veyangoda 100 miles away from the cotton-growing projects of the Department of the Agriculture (Warnapala, 1974). Accordingly, the most suitable locations were not selected for projects under these corporations due to political considerations i.e. the need to locate a factory in a particular constituency (Warnapala, 1974). These reasons, together with other factors, contributed to the low performance of these corporations. As a result, they were highly dependent on the Treasury for funds, which placed a burden on the government budget. Further, overstaffing due to political patronage was a serious problem (Salih, 2000). Political influence and interventions were prominent in the day-to-day activities of most of the enterprises, which led to mismanagement (Public Enterprises Department, 2003; Warnapala, 1974).

Consequently, most PEs operated at a loss for years. Examples of poor performers were: the National Water Supply and Drainage Board (loss in 1988, SLRs 400 million), State Plantation Corporation and Janatha Estate Development Board (loss of SLRs. 820 million in 1988), Pelwatte Sugar Corporation (loss in 1988, SLRs 255 million), Sri Lanka Transport Boards (loss in 1988, SLRs. 635 million) and Ceylon Shipping Corporation (loss in 1988, SLRs 374 million), (Adam et al., 1992). Although there were a few profit-making enterprises, Mineral Sands Corporation 
(profit in 1988, SLRs. 300 million), Lanka Milk Foods (SLRs 60 million), and Ceylon Electricity Board (SLRs 1135 million), the overall loss of productivity paved the way for their privatisation in the 1980s, which will be discussed later.

Despite their poor performance PEs began to grow while weakening the private sector in the economy. It was estimated that by the mid 1980s there were over 280 PEs, out of which 165 were commercial (Central Bank, 1998, p.215). Most of the respondents ${ }^{39}(60 \%)$ in this study commented that nationalisation programme created more economic and political problems, and was meaningless.

Daya Liyanage, Head of the National Procurement Agency, commented,

The nationalisation of private entities killed the entrepreneurship. That is why still our private sector is weak. In addition, nationalisation of plantations paved the way for the evolution of giant trade unions affiliated with the political parties (Interview, 07.01. 2008).

Furthermore, the establishment of PEs provided members of the bureaucracy and the politicians with an extra area for intervention and influence, and opportunities for nepotism and corruption.

\subsubsection{Creation of Branch Offices of Departments}

The other reform of the 1950s and the 1960s was the creation of branch offices of central departments in the districts. The departmentalisation resulted in the reduction of responsibility and authority of the GA who is the chief executive of the district (Wijeweera, 1988). The branch offices of the central departments operate in isolation as independent agencies, receiving orders from their respective head offices and reporting back on matters relating to the district, ignoring the GA. This hindered economic and social progress and increased waste of resources. The lack of coordination of various departmental activities at the district level created many problems for the decentralisation and devolution of the country, as discussed in Chapter 4.

\footnotetext{
${ }^{39}$ In this case the respondents are to be anonymous.
} 


\subsubsection{Abolition of Ceylon Civil Service (CCS) and Creation of Unified Administrative Service -1963}

The other administrative reform initiative undertaken by the UF Government was the abolition of the CCS and the creation of the Ceylon Administrative Service (CAS) in 1963, or Sri Lanka Administrative Service (SLAS) as it is called today (De Silva, 1993; McCourt, 2001; Somasundram, 1997)). Until 1963, the public service managerial cadres were composed of two categories: CCS (All Island Service) and non-CCS (confined to departmental services).

The CCS was composed of British nationals during the colonial rule, but at the dawn of Independence Ceylonese were gradually admitted into this cadre. A limited number of 22-24 year-old university graduates were recruited based on the result of a competitive examination. The annual intake was limited to four or five. The majority were from rich families and held almost all of the top positions in the public sector. At the time of Independence CCS was in a very strong position, with due respect and recognition. As a result, the officers enjoyed adequate autonomy and they became the most important segment of the administration. According to Weerakoon (2004, p.127), although rural intellectuals entered into this service after Independence, "they tried to maintain the tradition of the impartial, learned, and omni competent advisor".

The candidates who were not successful for CCS were recruited to non CCS cadres in various government departments. According to the Salaries and Cadre Commission - Wilmot Perera Commission - (1958/61), though they failed to secure places in the CCS, there was very little difference between their intellectual standards and those of the successful. However, they were subordinate to the CCS cadre.

These two sets of bureaucrats were paid differently and were promoted differently. The CCS cadre could freely transfer among government agencies while non-CCS had to work at the same place until they retired. Their promotional prospects were limited. 
V.K. Nanayakkara, Former Secretary to the Ministry of Education, in an interview said,

A clerical officer could become Administrative Officer and could go up to Secretary Level [because CCS grade III was allocated to the promoters of the clerical cadres]. For example, V.C. Jayasooriya, a very exceptional bright individual, joined the public service as a local government clerk and ended up as the Secretary to the Ministry of Home Affairs and Local Government, whereas an Assistant Commissioner who joined as the departmental officer (non CCS), for example, an Assistant Commissioner of Co-operative or Agrarian Services, could only become a Deputy Commissioner. He could never become Commissioner because the commissioner posts exclusively for the CCS. In CCS you joined as a Cadet, and then were appointed as the Commissioner. But others cannot go to that level (Interview, 06.11. 2007).

This meant that CCS employees were able to get a wider range of experience on various tasks and enjoy more privileges than their counterparts in departments. Therefore, there was a division among these two groups in the public service.

Against this backdrop, there were two anti CCS Commissions in the public service due to the agitation by non-CCS cadres: the Poulier Commission (1953) and the Wilmot Perera Commission (1961).The Poulier Commission proposed two levels of recruitment, but this scheme was unable to eliminate the problem of the 'caste system' in the public sector (Warnapala, 1974). Similarly, the Wilmot Perera Commission also condemned the CCS "as a perpetuation of a caste system in the higher public service" (Wijeweera, 1988, p. 289).

The Wilmot Perera Commission (1958-61) realised the need for urgent reforms to unify all administrative grades in the public service and recommended abolishing the CCS and absorbing its members into a unified service. More importantly, as a part of moving away from a neutral bureaucracy, the UF politicians viewed the CCS cadre as elitist and not responsive to the needs of the general people. According to Weerakoon (2004, pp. 127-128), who was also an officer of the CCS until its abolition,

The primary reason for the change seemed to be that, Felix particularly, [Minister of Justice] and a few of other ministers, were not too comfortable with having their chief administrative advisors being people with their own individual minds and opinions. They would have preferred less debate and more action once the political decisions had been taken...

In addition, 
A civil servant was a prized catch for the daughter of a successful businessman or a rich land owner. There were many CCS members of acute intellectual brilliance who had been snared by very rich bus magnates or owners of vast areas of coconut and rubber land [s]. Felix's point was that with all this acquired wealth behind them, would they [CCS cadres] be able to implement the programme of socialistic reforms the government had in mind?

The UF government realised that it had to transform the colonial bureaucracy in order to ensure that its socio-economic development programmes were efficiently implemented. The timing was right for the UF government to introduce reforms because its assumption of power marked the end of colonial features in the independent nation. Its electoral victory gave the UF government the mandate to introduce comprehensive reforms to the public service, to change the civil servants' mentality and make them more sensitive to the population's needs. In addition to favourable timing, the UF leaders had a favourable attitude towards administrative reforms. The other most important motivation for administrative reform was to ensure its political survival. It needed a supportive civil service to ensure its reelection to political office by helping it to fulfil its electoral promises.

Accordingly, despite the CCS's reputation for honesty in service delivery, the nationalist politicians abolished the traditional structure of administration in 1963. They might have realised that the degree of risk involved in not reforming the civil service was greater than the risk accompanying the implementation of the reform due to resistance. They felt they had nothing to lose if the hostile and alienated civil servants were reoriented and persuaded towards the achievement of national development goals. On the other hand, the UF leaders were also uncertain of their long-term survival and their ability to deliver the goods if the status quo was maintained and if the civil servants would be allowed to behave as they had in the past. Accordingly, all administrative cadres above the executive level, belonging to the CCS, and other departmental cadres were absorbed into a unified Administrative Service $^{40}$ (De Silva, 1993). "The civil servants were given the option to retire immediately 'on abolition of office terms,' or of retiring within the next 10 years on the same generous terms" (Weerakoon, 2004, p. 128).

\footnotetext{
40 At the time of setting up the CAS there were 209 members of the CCS, and 821 administrative officers of executive rank in the public service. They all brought together, despite their seniority (years of work). As such, those who recruited to the CCS in 1962 were given the same seniority as other administrative officers with 18 years of service.
} 
K.H.J.Wijayadasa, the former Secretary to the Prime Minister and the President (1984-1994), who was also a member of CCS until its abolition commented,

To my knowledge abolition of CCS was premeditated revenge by politicians because politicians couldn't interfere with CCS. They couldn't do things the way they wanted. The CCS was a hindrance to their political ego and self enrichment. Interference in day to day administration was not allowed, especially in appointments. What politicians of the post-Independence period wanted was for every person to come to them and get everything done through them from birth certificate to death certificate, jobs, and promotions, to keep the voter tied to them. The CCS was a hindrance for that, so they abolished it (Interview, 11.01.2008).

It appeared that the abolition of CCS had many shortfalls soon after its implementation such as inter-service jealousy (Wijeweera, 1988), disappointment among the public servants, lack of morale, inefficiency in service delivery, gradual politicisation, political patronage, and lack of emphasis on training and career development (De Silva, 1993; Warnapala, 1974). More importantly SL lost the service of many high intelligent people due to the retirement of many CCS officers as a result of these reforms.

However, there were some positive effects of this reform. The most positive effect was that rural Sinhala educated youth got a chance to enter the Administrative Service soon after graduation, and were able to advance their careers which were hitherto confined to elites and English-educated rich people. The study of 'a Sociological Analysis of Present Recruitment to the SLAS by Amunugama in 1977, highlights that the new recruits to SLAS tended to come from rural schools and lower to middle classes of society. Therefore, rural middle-class youth directly benefited from this reform.

The other positive effect was that the new system had several novel initiatives for the procedure of recruitment (Warnapala, 1974). Annually around 40 to 50 people, at the lowest level of the service, were recruited.

The other important feature of the new system was allowing females the opportunity to enter the service for the first time since Independence, although this was limited. Only $20 \%$ of vacancies were opened to women (Warnapala, 1974). However, it was 
a big achievement for females to hold higher posts in administration; thus qualified females directly benefited from this reform.

Another significant aspect of change was the recognition of the three languages, Sinhalese, Tamil and English for the recruitment examinations (Warnapala, 1974, p. 339). Applicants were given a chance to sit in the same language in which they had obtained their qualifications. These changes in the recruitment process and procedures indicated the need to recognise the changing social and economic environment. Therefore, the new system created a relatively wider base for people to compete in order to get a place in the administrative service.

In summary, the creation of a unified CAS in 1963 ended the 150-year-old prestige of the CCS. The caste system embedded in the CCS gradually disappeared and public service recruitment was carried out on a broader base. This attempt was seen as a first step towards modernisation of the colonial administrative system, but the quality of service over the years since then deteriorated for many reasons which will be discussed throughout this chapter.

\subsubsection{Abolition of Village Headman System}

Another reform introduced by the UF government was the abolition of the office of the 'village headman' (VH) in 1963 and replacing him with the Grama Sevaka (servant of the village) to cater to the needs of the villagers. The $\mathrm{VH}$ were used by the British for the duration of their rule. This system was considered an integral part of field administration and the focal point of all village level matters. (Warnapala, 1974). Every department sought his help to initiate any programme at that level, irrespective of their district or regional organisations (Warnapala, 1974). The colonial rule retained the VH system for the smooth running of administration. The VH carried out multifunctional roles. The Chief Headman $(\mathrm{CH})$ assisted the GA in general administration, especially in maintaining the law and order ( $\mathrm{VH}$ has the authority to solve petty disputes in the village), channelling communication between illiterate masses, supervising minor headmen, supervising crown forests and issuing of licences and permits, supervising land colonisation schemes and irrigation works, revising list of voters, and providing information required by the Government 
(Warnapala, 1974). Later, with the expansion of departments in the periphery, the headmen were relieved of some of their functions.

The VH system was located in the feudal system of administration. The $\mathrm{CH}$ was selected from principal families, especially in the Kandyan Provinces. In the low country, government servants with good track records were sometimes appointed. However, high caste became the main criteria for appointment in addition to having wealth and influence in their divisions (Collins, 1951).

By the 1920s, despite their prestige, there was a demand for total abolition of the system. Two Commissions set-up in 1920 and 1935 investigated the system and concluded that it was corrupt (Warnapala, 1974). Wilmot Perera study (as cited in Warnapala, 1974)) further states that the system of recruitment entrenched privilege and suppressed the lower social classes. There were several possible reasons for this. The first reason was that $\mathrm{VH}$ worked without pay. As they were landowners who came from prestige families, they were able to give free services to government. over time this changed and minor headmen received fees and pecuniary rewards for various services. The Commission of 1920 (as cited in Warnapala, 1974, p. 345) did not encourage a salary payment for them "on the ground that remuneration would convert the VH into entirely a different type of officer". Although there was no rationale for this decision, they continued allowances, fees, and reward payments. Their services were rewarded insufficiently in monetary terms, which led to corruption. Later in 1922, a remuneration system was introduced, but this did not improve the situation.

Although there was an urge for reform, the system continued. The reason according to Warnapala was "the manifold advantages it offered to the party in power". ${ }^{41}$ There was a view that the UNP politicians used the system as a political buffer. With the change of government in 1956, the need for reform became more crucial. The Government made no new appointments and allowed $\mathrm{CH}$ to retire at the age of 55.

\footnotetext{
${ }^{41}$ It was alleged that D.S. Senanayake convened a conference of VH to "counteract the influence of S.W.R. D. Bandaranayaike in the Village Committee Conference". It was also said that Sir Oliver Gunathilake, when he was the Minister of Home Affairs, convened a conference of VH and wanted them to support the UNP (Warnapala, 1974).
} 
The government also abolished minor $\mathrm{VH}$ and transferred their functions to newlyappointed Cultivation Committees. After that the Government decided to compulsorily retire all $\mathrm{CH}$ in 1961 (Warnapala, 1974). "The underlying assumption of these changes was that they were essential elements of a wider policy of eroding the support base of the UNP within the bureaucracy" (De Silva, 1993, p. 89). As such, the ultimate motivation for reform was political rivalry rather than administrative modernisation.

In 1963, the VH system was replaced by the Grama Sevaka Service (servants of the village) (De Silva, 1993). A Grama Sevaka was selected through a competitive examination and he was transferable. N. Pathmanathan, former Deputy Secretary to the Treasury, in an interview said,

A man who thought that he was a head of the village became a servant of the village with this reform. Later in the 1990s this designation was again changed into "Grama Seva Niladari $^{42}$ owing to high agitation of the Trade Union and in the recent past this post was redesignated as "Grama Niladari" again on the same agitation. They are no more "sevakas" in the village rather "Niladaries" or "officers" in the village (Interview, 02.01.2008).

Under this reform four categories of village level field officers were brought into the Grama Niladari Service. They were: Grama Sevakas, Cultivation Officers, Agricultural Extension Officers, and Vishesa Seva Niladaris (Special Services Officers). Most appointments were done under the patronage of politics (De Silva, 1993). Under this reform, each village was given a Grama Niladari to help villagers to receive many of the public services as easily as possible. Despite shortfalls in the system such as delays, corruption and malpractices in the service delivery, this reform changed the norms and style of administration at the periphery. The high caste, privileged village elite, lost the opportunity to be in the administrative system anymore. They lost all privileges and connections with higher bureaucrats in the divisional and district level. This negatively affected their status as well. In contrast, the reform benefited the village youth as it allowed them to enter the administrative machinery irrespective of their caste and position at village level. Introduction of competitive examinations for selection benefited all talented youth, thus the government also gained credit for the reform.

\footnotetext{
${ }^{42}$ The Sinhalese word "Sevaka" means "Servant" and "Niladari" means "Officer" which gives high recognition to the post and to the person who hold that post, in the SL context.
} 
However, many respondents ${ }^{43}$ in this study mentioned that those who succeeded were not particularly good and the CAS and GS systems did not bring better results to the local people in the same way as in the old British empire. According to them, the present systems are riddled with inefficiency and corruption, which make it difficult for the poor men at village level to reap full benefits of government programmes.

\subsubsection{The Committee of Secretaries and the Standing Committee on Administrative Reforms 1966/69}

In the late 1960s there was an increasing dissatisfaction about the performance of the public service. Thus, the UNP government, which came to power in 1965, created a number of institutions at ministry level such as a Plan Implementation Committee and a Foreign Exchange Committee. In addition, a Committee of Secretaries chaired by the Secretary to Treasury was appointed, to report on,

Administrative reforms;

New financial regulations;

Tender procedure; and

Procedures and organisational changes required in the context of development programmes" (Nadarajah, 1997, pp. 248-249).

The Committee observed that there was a lack of systematic programme evaluation mechanism, and an "individual performance" evaluation system in the public service. It also witnessed the reliance on seniority, not merit, in making promotions in the public service. The core recommendations of the Committee were:

Establish a 'Standing Committee' to examine the administrative set-up and to make recommendations on changes;

Re-organise the structure of ministries and departments;

Establish a staff training institute to carry out induction training and encourage in-service training; and

\footnotetext{
${ }^{43}$ In this case the respondents are to be anonymous.
} 
Delegate financial responsibility and authority (Nadarajah, 1997)

Some of these recommendations were implemented: a Standing Committee on Administrative Reform and an Academy of Administrative Studies were established, and the Financial Regulations were revised, enabling more delegation of authority to lower levels than before. Integration of departments with ministries was carried out in an ad hoc manner. According to the Secretary to Treasury who led the Standing Committee on Administrative Reforms (as cited in Nadarajah, 1997, pp. 249-250),

The proposed integration of ministries and departments has been carried out in a few ministries with some measure of success, particularly where ministries and departments are located in close proximity to each other. In other ministries, departments' heads had not welcomed the proposal and ministers have not been inclined to implement them.

This Committee lasted from 1966 to 1969. At the end of the three-year term, the Secretary to the Treasury (as cited in Nadarajah, 1997, pp. 250-251) admitted in his report that they could do very little in the area of administrative reforms,

It is useful to review briefly how these recommendations were implemented and the measure of success they achieved in improving the quality of the administration. The standing committee on Administrative reforms has functioned from 1966-1969. Having been its Chairman, I must confess it has little achievement to its credit. The members were all senior officials preoccupied with heavy departmental responsibilities. Often they were unable to attend meetings. Most of them were so senior and so used to the existing institutions that they had ceased to be critical. When a problem was brought up for consideration, the inclination was to reminisce rather than [to] critically analysed (sic). The arrangements for servicing of the committee were inadequate. Administrative reforms not having been assigned to any minister as a special responsibility did not come under any ministerial supervision or direction. A circular sent out to the public service explaining why the committee was appointed and inviting suggestions for administrative changes evoked little interest and very few suggestions emanated from the entire public service.

Although administrative modernisation was recognised as a priority from 1956, this evidence suggests that until 1969, there was no proper institutional arrangement put in place to realise it; rather ad hoc arrangements seemed to have been made.

In summation, the reforms during the 1950s and 1960s were mixed, largely political in nature with some elements of decentralisation of administrative functions. The language reform had far-reaching adverse effects on administrative functioning due 
to its ineffective implementation, while abolition of the CCS and VH system had some overall positive effects.

\subsection{Part II: Reforms during the 1970s and 1980s}

The UF led by the SLFP came into power with a two thirds majority in 1970 and established a separate ministry called the 'Ministry of Public Administration' to create radical changes in the administrative set-up. Until then, the public service functioned under the Ministry of Finance. The creation of a separate ministry was intended to give a new direction and recognition to public administration. Nevertheless, it failed to do so (Somasundram, 1997). It is also noteworthy to state that after more than three decades from its inception, it was unable to direct public administration into a new era of public management, at a time when other countries shifted from traditional 'public administration' to 'public management'.

In addition, this government focused on administrative decentralisation during its office because decentralisation of authority was seen as an essential feature of economic and social development of the post-independent era. The government wanted to change centralised policies and the bureaucratic systems set-up under the colonial time in order to meet the aspirations of the people (Wijeweera, 1988). Therefore, it established several institutions at local levels and delegated decisionmaking authority to the lower level. In fact, all the reform initiatives during this era have had profound implications over today's public administration, thus it is worthwhile to examine their implementation in depth.

\subsubsection{Divisional Development Councils (DDCs) -1971}

The primary motivation for the introduction of DDCs was the youth insurrection which occurred in 1971 due to the unemployment problem and the social unrest over political interventions in all spheres in public administration. The unemployment increased from about 340,000 persons (10.5\% of the labour force) by $1959 / 1960$ to about 546,000 persons $(13.9 \%$ ) by $1969 / 1970$ (Kearney, 1973, p.735) due to slow economic growth. It became a crucial problem because most of the educated youth sought white-collar jobs, particularly in the public service. 
However, in the public sector job opportunities were under political patronage. Due to the lack of open methods for recruitment, government MPs were given tremendous power in these appointments. For example, in the appointment of teachers each MP was given a fixed quota to fill. Very often the person who got the job was a close relative to the MP or had access to the patronage network through their elite connections. In some cases, the wealthy people who were politically opposed to the MP got the jobs, due to bribery or power to manipulate the system. According to Leitan (1979, pp. 208-209), "it was also revealed by the Co-operative Wholesale Establishment (CWE) Commission of Inquiry that when the Chairman and Director of the CWE Board resigned on $9^{\text {th }}$ January 1965, there were over 100 letters and chits, majority were from SLFP and LSSP Parliamentarians, requesting appointments in the CWE for various people, for example, a letter from a minister addressed to Chairman of the CWE requested him to "fix him up in any capacity in the CWE", Another letter, 'please give him a job in any capacity in Dikwella area. This is a must and it has got to be done. I have attended to your matters".

The political patronage was not only confined to offering public sector employment but also spread to all other areas in the public sector, for example, the choice of areas for rural electrification or water supply schemes (De Silva, 1993). The youth insurgency was a social explosion against these unjust practices in public administration.

In response, the SLFP Government (1970-1977) established DDCs ${ }^{44}$ in order to implement crash employment generation projects under the purview of the Divisional Revenue Officers ${ }^{45}$ (DRO). The DDCs were composed of both officials and non-officials, including local MPs (Wijeweera, 1988).

The main thrust of the DDCs was to promote small-scale industries using rural resources, with the aim of generating "50 units of sustained employment" per DDC (Wijeweera, 1988). The DDCs were required to manage these projects through co-

\footnotetext{
${ }^{44}$ For administrative purposes SL has been divided into 9 provinces, 25 districts and 320 divisions. The GA is the Administrative Head of the district while DRO was in the division.

${ }^{45}$ This position was re-designated as Assistant Government Agent (AGA) in 1975 and Divisional Secretary in 1990.
} 
operative institutions under the guidance of Divisional Development Assistants, who were public officials recruited from among the unemployed graduates. The GAs of the districts along with other relevant district officials coordinated these projects, and funds were released to the GAs by the Treasury (Wijeweera, 1988). Thousands of projects were implemented within a short period of time.

However, this programme had its own deficiencies. According to Richards and Gunarathna (as cited in Herath, 1991), many of the projects have been strongly criticised for poor initial choice of product, lack of facility for marketing, lack of enthusiasm by co-operative members, and failure to create significant additional employment. Furthermore, there was a lack of expert knowledge on project formulation and appraisal on the part of both the DDC's and GA's staff (Wijeweera, 1988). In addition, the technical departments, such as the Department of Irrigation, Water, Agrarian Services and Small Industries, continued to maintain their 'departmental' orientation rather than 'district' orientation. These reasons hindered the effective co-ordination at the district level. Moreover, this decentralisation programme remained merely an administrative exercise, failing to gather support of the beneficiary groups. In addition, the system itself was totally reliant on the personal initiative and leadership of the GAs and AGAs. The failure of the DDC system had negative consequences on the bureaucracy and public management which led to the introduction of political authorities in 1973 (Section 5.4.3).

\subsubsection{Abolition of the Public Service Commission (PSC) - 1972}

Under the Order in Council of 1946, the public service personal management were placed under the independent PSC. This Commission was abolished and its powers and functions were transferred to the Cabinet of Ministers by the new Constitution in 1972.

The main justification for the legislation was that the government, which is responsible to Parliament for its policies and operations, needed to have full control of public officers who are required to implement them. Another argument was that in a rapidly developing society, the public service had remained a partial instrument of 
the elite and unresponsive to the needs of vast majority of people (De Silva, 1993). This fact was reinforced by V.K. Nanayakkara, former Secretary, Ministry of Education, in an interview,

Dr. Colvin R. De Silva [who was a lawyer by profession and one of the architects of the 1972 Constitution] used to say that 'as Ministers we are responsible for public servants. We defend the public officers in Parliament. If Ministers are responsible for the activities of the public servants they should be given the authority for their appointments, promotions etc'... One of other reasons was that previous Governments, especially the 1956 Government wanted to do drastic changes, but public officers, CCS, resisted them. Because of that they felt that they need some control over public servants (Interview, 06.11.2007).

Articles106 (1) and (2) of 1972 Constitution state:

The Cabinet of Ministers shall be responsible for the appointments, transfer, dismissal and disciplinary control of state officers,

Subject to the provision of the Constitution, the Cabinet of Ministers shall have the power of appointment, transfer, dismissal, and disciplinary control of all state officers.

Under Article 106 (3), the Cabinet of Ministers also was empowered:

to determine all matters relating to public service including the constitution of state services, the formulation of scheme of recruitment, and codes of conduct for the state officers, the procedure for the exercise and the delegation of the powers of appointment, transfer, dismissal, and disciplinary control of state officers.

Accordingly, the Cabinet was empowered to deal with all personnel and administrative matters of public servants. However, the power vested in the Cabinet could be delegated to an individual Minister by Article 115 and this individual Minister in turn could delegate his authority to a state officer. However, the Cabinet kept its vested power over senior public officials such as Heads of Departments, Additional Secretaries and Senior Assistant Secretaries while delegating lower level staff matters to public officials. Nevertheless, under Article 116 of the Constitution, "the Minister with the concurrence of the Cabinet of Ministers could act in regard to any matter so delegated to a staff officer". In this manner an individual Minister was given exclusive authority over any matter in relation to public officers who are under his purview.

To support the Ministers, this Constitution made provisions to create two bodies: the State Services Advisory Board (SSAB) and State Services Disciplinary Board (SSDB). Each Board consisted of three members for a term of four years and 
functioned merely as advisory bodies to Cabinet. The SSAB gave recommendations to the Cabinet in making decisions on matters related to appointments, and transfers, while the SSDB gave recommendations on matters relating to dismissal and disciplinary control. Members of Boards were appointed by the President but they cannot be removed by the President without advice of the Prime Minister. A member of one Board couldn't be appointed to the other. A Minister was supposed to make decisions after receiving recommendations from these Boards.

The crux of this Constitution was Article 106 (5) which explained:

No institution administering justice shall have the power or jurisdictions to inquire into, pronounce upon or in any manner call in question any recommendation, order or decision of the Cabinet of Ministers, a Minister, the State Services Advisory Board, the State Services Disciplinary Board, or a state officer, regarding any matter concerning appointments, transfers, dismissals or disciplinary matters of state officers.

Furthermore, under Article 117(2) and (3), the decision of the Minister was final in appointment and transfer, but in a case of a dismissal a single appeal could be made to the Cabinet of Ministers, who had the final say.

Accordingly, the Constitution protected the Cabinet, individual ministers, two boards and public officers responsible for the public service personnel management from any legal action in powers vested in them. A public servant had no chance to use even conventional judicial institutions, if any injustice was done to him/her thus, the first step towards politicisation of the public service started in 1972, with proper legal backup.

The results of this reform were seen soon after. The officers of the SLAS, involved in district administration, were transferred when they had problems with politicians in the districts (Somasundram, 1997). For a long time, the Ministry of Public Administration maintained a 'pool' for such officers who were transferred on the insistence of politicians until they found another work station. On some occasions a SLAS officer, who wanted to work in the division, first had to talk to the local MP for his approval (Sirivardana, 2004). This process was significant at district and divisional levels but there were no exceptions at ministerial level as well (personal observation). 
In this manner, the once independent SLPS has been progressively undermined. Its independence was further diluted by ignoring competitive examinations for recruitment to the public service due to the introduction of the "Chit System" 1970s by the UF Government and the 'Job Bank' ${ }^{47}$ system in the 1980s under the UNP Government.

The senior public officials who succumbed to this radical transformation described this reform, in the words of K.H.J. Wijayadasa, former Secretary to the Prime Minister and President (1984-1994),

The abolition of the PSC was really a disaster that engulfed the public service. The independent PSC served minorities better. This was also the start of the politicisation of the public service. This aggravated ethnic conflict. In the olden days everyone in the district respected the GA. But now it is not there. They think that the GA is a henchman of the politician. He may not deserve this label. The primary motivation was to make the public servant subservient to the politician. They wanted the public service under them. This was done purposely. It demolished the hierarchical order of the public service (Interview, 27.12.2007).

A similar view was expressed by Professor, S.W. Ranasinghe,

They opened the door for politicisation of the entire public service. Under the previous Constitution no politician could remove any public servant, and they held positions at the pleasure of the Crown. Under the 1972 Constitution it was at the pleasure of the Cabinet of Ministers. Again, here it is the Cabinet as a whole does not take decision. An individual Minister could interfere and take decisions. It was politically justifying their decisions. It was not illegal. The Minister in charge of the subject had power to make any decision over public servant under his purview (Interview, 11.12.2007).

S. Ranugge, Secretary of Ministry of Export Development and International Trade, said,

It is the worst piece of legislation. The content with regard to public service is not good. It killed the public service. It paved the way for institutionalisation of political ideas in public administration. Today also we suffer (Interview, 09.11.2007).

\footnotetext{
${ }^{46}$ Under the 'Chit system' a candidate had to take a letter from the MP of the area to support his/her application for a job, promotion, or a transfer. It was extended to dismissal or disciplinary control matters too. If the MP of the area was not a member of the Government party, a letter from the Chief Organiser of the Government party was mandated. This system was implemented by the SLFP government (1970-1977)

${ }^{47}$ Under the 'Job Bank' system, the MP of the area distributed job applications to his supporters and they were registered in the 'job bank' set-up in the Ministry of Plan Implementation. Under this system even application for a job was restricted to MPs' wishes. This system was implemented by the UNP government (1977 to the1980s).
} 
Daya Liyanage, former Deputy Secretary to the Treasury, in an interview expressed similar views,

Not only public service people suffer. Abolition of PSC badly affected [everyone] (Interview, 07.01. 2008).

Y.G. Wijerathna, Additional Secretary, Ministry of Plantation Industries, said that, Negative effects are more. Independent decisions cannot be taken due the fact that the Secretaries and Heads of Departments are appointed by the politicians. Even now. The quality of the public service deteriorated, it led to inefficiency of the public service, because suitable persons are not in proper places (Interview, 03.12.2007).

As such, the abolition of independent PSC in 1972 had negative implications for public administration. It was the first step towards politicisation of the public service.

\subsubsection{District Political Authority (DPA) - 1973}

The third attempt at administrative reforms by the UF government was the setting-up of DPAs. The shortfalls in the DDCs discussed previously provided a base for politicians to adopt alternative ways to address the problems of bureaucracy. This meant that the UF government thought that the political intervention was a panacea for bureaucratic incapacity, inefficiency and delays. The politicians did not bother to reform bureaucracy or change their attitudes. Instead, they seemed to seize the opportunity for their own advancement at the time when the country faced a food crisis due to global food shortages and severe drought in the country. So they established political authorities.

The Prime Minister appointed a senior member of the National State Assembly (Legislature) in each district as Political Authority and assigned a special responsibility in regard to food production (Leitan, 1979). Accordingly, 20 DPAs were established: three were headed by Ministers, twelve by Deputy Ministers and the remaining five by senior backbenchers. Thus, political leadership was established in the district, replacing the GA's role by making him the secretary to the DPA. It had been the second attempt in politicisation of public administration in SL (the first attempt was the abolition of the independent PSC). Therefore, it was seen as a drastic change in the traditional administrative system. 
One of the tasks of the DPA was to identify non-cultivated paddy lands and make arrangements to bring them all under cultivation while providing inputs, and facilitating marketing functions. The DPA was instructed to work with other MPs in the district cohesively. Funds were allocated to the DPA by the Treasury via GA. The GAs were entrusted with financial management of the DPAs. However, there was no instructions on the demarcation of authority of the GAs and DPAs or reduction of the GAs' powers, but the GAs were required to work in accordance with the decisions of the DPAs in the districts (Leitan, 1979).

A separate agency called the "Prime Minister's Coordinating Secretariat" was created at the centre to direct and guide the district agricultural programme through DPA. Its main tasks were the supervision of field operations, review of progress, and coordination of all relevant ministries on food drive programmes (Leitan, 1979). It was directly under the PM and led by one of the PM's daughters. She was assisted by the Deputy Minister of Planning and Economic Affairs, Deputy Minister of Defence, Army Commander and Director of National Planning of the Ministry of Planning and Economic Affairs, and as such, it was principally a mixture of political, military and bureaucratic officials (Wijeweera, 1988). They sorted out problems which arose between the DPA, the GA and the departmental officers (Leitan, 1979).

However, the DPAs faced many problems. The main problem was the lack of enthusiasm by ministers to delegate ministerial functions (Wijeweera, 1988). Although there were two circulars of instructions, one for the DPAs and the other for the GAs, the scope of the functions of DPAs was not clear. The DPAs had to continuously depend on line ministers. According to Wanasinghe (Chair of the ARC) and Dr. Abeywardene (Former GA), some of the DPAs were very effective and the centre was afraid to delegate more authority to them (Interviews, 31.12.2007 \& 15.02.2008).

Another problem was the drastic reduction of funds in later years. A further problem was that DPAs were given tremendous powers in various other activities which were widely misused, for example, selection of allottees in housing and lands distribution (Wijeweera, 1988). Furthermore, there was lack of support from the GAs; according 
to Wijeweera (1988) some of the GAs did not provide office facilities for the DPAs in their premises, and only a few volunteered to be their secretaries. In an interview, this was confirmed by Andrew de Silva, a former GA in Kalutara (Interview, 07.11.2007). Nevertheless, this system operated until the government changed in 1977. This reform had far-reaching negative implications for public management.

\subsubsection{Introduction of Decentralised Capital Budget (DCB) - 1974}

The UF government thought that mere delegation of authority to lower levels would not be meaningful without any financial support. Therefore, as a means of strengthening the decentralisation of development administration through DPA, the budgetary system was also reformed by the Cabinet decision of $13^{\text {th }}$ June 1973 , granting formal approval for the commencement of the DCB in 1974 (Wijeweera, 1988). The DCB is a programme that allocates public funds to MPs for development projects in order to address the needs of the people of the district that the MP represents and for which there is no allocation from other sources of funding (Ministry of Policy Development and Implementation, 2007).

According to Weerakoon (as cited in Herath, 1991), the main purpose of the DCB at the initial stage was to increase food production and employment in the village level through development programmes and increase participation of people in the planning and implementation of such programmes. The hidden motive of the DCB was to encourage volunteer work and/or material resources in the area, for example, if a project costs SLRs 20,000, the allocation was only 15,000 . The balance could be made up by volunteer work. It is assumed that because the local MPs were the key players in the DCB, this could have been organised easily. This was evident in the DPA system (Wijeweera, 1988). Nevertheless, over time this concept got diluted.

The implementation of the DCB has gone through several changes since its inception. Initially, a portion of funds was shown in the estimates as the 'Decentralised Budget'. The Treasury released these funds to respective departments, on request through their functional ministries. Then the departments reallocated these funds to branch offices in the district. This system did not fully support the 
development programmes submitted by MPs, thus MPs had to go through the same process that had prevailed in the previous system. In addition, the government MPs were able to press for a larger portion of the $\mathrm{DCB}$, while Opposition members were neglected (Herath, 1991). Due to repeated requests from MPs, this system was changed several times.

Accordingly, the Treasury allocated DCB money to the Ministry of Planning and Economic Affairs, which established a separate division for the DCB. This Ministry then allocated DCB funds to districts for capital work via GAs. The GAs reallocated these funds equally to electorates. With the establishment of the District Minister system which will be discussed next, this system further changed. Then, an allocation of SLRs 2.5 million was provided for a MP from 1979. During the 1980-1990s, the Ministry of Plan Implementation was responsible for the implementation of the DCB programme. Later the amount of allocation per MP was also increased to SLRs 3.5 million in 2000, 5 million in 2003, and has continued until now. The responsibility for implementation was moved to the Ministry of Rural Livelihood Development in 2005. Currently (2009) the Ministry of Nation Building and Infrastructure Development is entrusted with the implementation of the DCB. Now MPs can sponsor projects throughout the district as they wish, not confined to electorates. Thus, the implementation mechanism changes according to the whims and fancies of the political party in power.

According to Oberst (1986, p. 169), this reform put the local MPs "in the position of development administrator". Before the DCB, the average MPs did not have any decision-making authority or power. Most of their time was spent on listening to their constituents' grievances and complaints. Their main role was only confined to vote for the party proposals in Parliament. The DCB augmented an important component to their job by putting them in the administrative structure. They now have the authority to plan and have decision-making powers (Oberst, 1986). They became a new force in development in the periphery.

In addition, this reform gave the GAs the responsibility over the decentralised allocations as discussed by appointing them as Chief Accounting Officers (CAOs) from January 1980 (Wijeweera, 1988). This was a novel feature in the budgetary 
system in SL, because normally CAOs are still the Secretaries of Ministries. In this respect the GAs were given high positions, such as secretaries of ministries, in the administrative system under the DCB. Therefore, this was a watershed in decentralised financial control. Prior to the DCB, most of the projects in the districts were implemented by the branch offices of the central departments. They ignored the GAs on many occasions (Oberst, 1986; Wijeweera, 1988) but under the DCB system the departmental officers have to work with the GAs, therefore they cannot ignore them as before. Now, the GA has the authority to allocate funds and thereby, monitoring of the projects. The progress reports were made available to local MPs so they clearly understood the implementation of projects.

Currently the scope of the DCB has expanded, $76 \%$ of the DCB is expected to be spent on socio-economic activities, covering priority areas from economic infrastructure to fisheries, health and sanitation, religious, social welfare and sports. Out of $76 \%, 50 \%$ is expected to be spent on development of rural roads. The capital works on religious activities, social welfare and sports are limited to $10 \%$ of the total provision (Ministry of Policy Development and Implementation, 2007). The funds cannot be moved from district, to district but there is a flexibility to move funds from one project to another in the same district.

The DCB necessarily calls for team work. For the effectiveness of the system, three key players, the GA, MP and officers of the branch offices, should carry out their legitimate role cohesively. However, the shift in power between these three key players badly affected the effectiveness of the DCB system. Oberst (1986, p. 170) explains,

There has been a limited amount of co-operation from departmental officers involved in the DCB. This lack of co-operation has largely been felt by those who do not have' the power to force action from the departmental officers (some back benchers, most opposition MPs, GAs, and Planning Officers).

It was evident that the progress reports were not sent in time to the GAs and the technical reports on potential projects were not filled in time by these departmental officers. The uncooperative behaviour of these departmental officers was the reason for the failure of the DDC System described in the previous section. These officers gave priority to their own projects rather than DCB projects. In addition, there was a 
lack of delegation in the departmental structure. Those branch officers have not given adequate authority to make decisions on the spot to complete their projects; for example, their technical reports on potential projects must be forwarded to their head office at Colombo for approval first, before they can be submitted to the GAs. After this tenders must be forwarded to the Departmental Head Office on subcontracting labour and material for approval (Oberst, 1986). These delays were unavoidable under then administrative structure. Therefore, failure to reform this structure led to a situation where "political power and influence determined the completion rate of the projects" (Oberst, 1986, p. 173).

In addition to these consequences, this system had other shortfalls. It is argued that theoretically these projects were expected to be planned, administered and implemented by the local people, but in reality they were and are purely initiated by the local MPs and the elite in the community level organisations. According to Siriwardena (as cited in Herath, 1991, p. 148), people's participation in planning and implementation of projects is minimal. If there was any participation, it was partial to the governing parties, because MPs dominate the DCB system.

As such, the DCB provides excellent opportunities to MPs to set their political priorities and wishes. Some of the respondents ${ }^{48}$ (10\% in this study) mentioned that in theory the DCB is very good but in practice it was corrupted. Today a large portion, $50 \%$, of the DCB is wasted. Today all contracts are awarded to political supporters. All projects are carried out by the relatives of MPs and the supporters. Therefore, the system has become corrupt. Political interference is strong in designing and prioritising projects. The GA get transferred if he/she does not comply with the political objectives (Fieldwork, November 2007-February 2008). Although the system has been in place more than 30 years, there has been no review done by the Ministry of Finance and Planning.

\footnotetext{
${ }^{48}$ In this case the respondents are to be anonymous.
} 


\subsubsection{District Minister (DM) System -1978}

The other reform attempt was the introduction of DMs in 1977 by the UNP which came into power with a landmark victory of five-sixths of the total number of seats in Parliament. According to Leitan (1979, p. 258),

A major aim of this system was the coordination of all development activities within the district by the district minister who would act as the connecting link between the central government and the district and ensure that development work decided by the government for the districts would be carried out efficiently and smoothly.

In order to facilitate this reform the government re-wrote the Constitution. A Presidential form of government was introduced. Article 45 (1) of the Constitution gave the President power to appoint ministers who are not members of the Cabinet,

The President may, from time to time, in consultation with the Prime Minister where he considers such consultation to be necessary - (a) appoint from among Members of Parliament, Ministers who shall not be members of the Cabinet of Ministers and (b) determine the assignment of subjects and functions to, and the ministries, if any, which are to be in charge of, such ministers. (2) The President may at any time change any appointment or assignment made under (1) of this article. (3) Every minister appointed this article shall be responsible and answerable to the Cabinet of Ministers and to Parliament (The Constitution of Sri Lanka, 1978).

This is the main innovation of this Constitution to accommodate the DMs. Accordingly, after promulgation of the Second Republican Constitution 22 DMs were appointed, in October 1978, one for each district except for Jaffna and Mullaitivu, which were filled a little later. All of them were first timers to the Parliament (Wijeweera, 1988). As such, the DM system replaced the former DPAs.

However, the functions of the DMs were not clearly demarcated. Similar to the situation in the DPA system, "functions were left open, wide and flexible, under the broad understanding of coordination" (Wijeweera, 1988, p.154). According to Wijeweera (1988), at the outset, the President informed the DMs that they should work in close consultation and in liaison with the line Ministers and act according to programmes approved by them. This meant they had to depend on central Government Ministers. Their level of effectiveness became a function of the relationship they had with the individual minister. In this sense the powers and functions of the individual DM could be varied, wide or narrow, from district to 
district on his administrative capability and wisdom. Against this background, the DMs acted merely as coordinators similar to DPAs.

In most ways, this system was not different from the previous DPA system. The only dissimilarity was that the DMs had the legitimate authority under the Constitution to act in the district level as special ministers, which they had lacked under the DPA system which had informal authority from the Prime Minister. This difference had no significant impact on their respective roles.

However, both the DPA and DM systems enhanced the political autonomy in the district administration while demoralising the bureaucrats at the district level. Therefore, in both systems politicians gained at the expense of the bureaucracy. Both systems paved the way for encroaching and eroding the legitimate authority and discretion of the public servants, thus continuing relentless politicisation of the public administration. The adverse effects of this political meddling were highlighted in the seminar organised by the SLIDA. The participants commented that;

Political interference in day today matters of administration has tended to erode the authority of the heads of departments and supervisors thereby destroying their enthusiasm and will to work. It is useless delegating duties unless at the same time sufficient authority is conferred to carry out such duties without fear or favour. Political meddling is this sort takes away the required authority formally delegated and thus undermines the process of delegation without which no administration can carry on (Wijeweera, 1988, p. 159).

Similarly, the DM system did not attract the Tamil minority who continuously demanded more power to carry out their tasks in the North and East where the majority of Tamils live because the appointments of DMs were not done in a proper manner to represent the local people. For example, the MP of Dambadeniya (Sinhalese MP - U.B. Wijekoon) was appointed as the DM for the Jaffna district where Tamils were the majority. So Tamils thought there was no point in having this system if they cannot elect their own DM. In response to these agitations the government strengthened the DM system by introducing elected councils in the early 1980s which will be discussed later. 


\subsubsection{Re-establishment of the Public Service Commission (PSC) - 1978}

The Constitutional reform in 1978 made provision for the re-establishment of the PSC which was abolished by the 1972 Constitution. However, powers vested in the Cabinet of Ministers by the 1972 Constitution on appointment, transfer, dismissal and disciplinary control over the public servants were not changed. The Cabinet chaired by the President retained the power in respect of higher grade officers such as 'Heads of Departments' but it delegated its powers on 'other public officials' to the PSC (Article 55(3)). The appointments of Secretaries in Ministries were on the sole discretion of the President as mentioned before.

This situation was described by the former Secretary to the Prime Minister Bradman Weerakoon (1956-1970, 2001-2004), in an interview:

The government of 1977 did not want to lose the advantages of 1972 Constitution, and they wanted to give the impression that they have done more (Interview, 20.11.2007).

The PSC could sub-delegate its delegated authority, in respect of staff grades, to Secretaries of the Ministries and in respect of non-staff ${ }^{49}$ grades to Heads of the Departments. The PSC was composed of not less than five members appointed by the President for a period of five years, of whom one of the members was nominated as the Chairman. The membership of the PSC was disallowed to Members of Parliament. Any public officer aggrieved by any order of transfer, appointment, dismissal or any other disciplinary matter by a public officer, could appeal to the PSC. However, the PSC was not an independent body as it was previously under the Order in Council of 1946. It implemented delegated authority of the Cabinet and functioned under the Cabinet. Therefore, impartiality of its decisions was not guaranteed.

Under Article 59, the Cabinet of Ministers had the power to alter, vary or rescind any decisions on appointment, transfer, dismissal or disciplinary order made by the PSC, or a public officer under delegated power or any order on appeals made by the PSC,

\footnotetext{
${ }^{49}$ Non-staff means non-managerial in the SL context.
} 
or any transfer order made by a minister. In this sense the final say rested with the Cabinet of Ministers, as in the case of the 1972 reform.

Similarly, Cabinet was empowered to determine all matters relating to public officers including formulation of principles in making promotions, which was not focussed on in the 1972 Constitution. These powers were not delegated to the PSC by the Cabinet. On behalf of the Cabinet, these matters were dealt by the Ministry of Public Administration.

The other fundamental change in this Constitution when compared to the 1972 Constitution was the appellate jurisdiction regarding affected public servants against decisions by the authorities. Article 55(5) stated that,

Subject to the jurisdiction conferred on the Supreme Court under paragraph (1) of Article no court or tribunal shall have power or jurisdiction to inquire into, pronounce upon or in any manner call in question, any order or decision of the Cabinet of Ministers, a Minister, the Public Service Commission, a committee of the Public Service Commission or of a public officer, in regard to any matter concerning the appointment, transfer, dismissal or disciplinary control of a public officer ${ }^{50}$.

Paragraph (1) of Article 126 stated that,

The Supreme Court shall have sole and exclusive jurisdiction to hear and determine any question relating to the infringement or immanent infringement by executive or administrative action of any fundamental right or language right.

Thus, the public servants were given the opportunity to appeal against decisions of the Cabinet or an individual Minister. The number of appeals was not specified by the 1978 Constitution as in the 1972 Constitution, but in practice only one appeal for a single case was applied by the PSC. Thus public servants were better off than under the 1972 Constitution, even with this limited appellant jurisdiction. This privilege has been used by many public officials. The following is an example:

\footnotetext{
${ }^{50}$ Public officer does not include a member of the Army, Navy, or Air Force.
} 


\section{Box 4: A Famous Historic Case of Ministerial Victimisation of a Public Officer}

Elmore Perera vs. Major Montagu Jayawickrema, Minister of Public Administration (1985) (SL Law Reports p. 285)

Elmore Perera was a Deputy Surveyor General who was seconded to the SLIDA at the time when he was maltreated and punished by the Minister of Public Administration on a personal animosity, which arose out of a private dispute at a tennis club where the Minister regularly played tennis and Perera was the President. The dispute was on a rule of the tennis club that restricted each member half an hour's play at a time which had been introduced to give a fair chance to all members, because there were only a few tennis courts. This rule had not been enforced against the Minister because of his position, but this changed after Perera became the President. Perera was warned through his superior officer at SLIDA not to interfere with the Minister in playing tennis but Perera did not stop.

As a result, Perera was informed that his services at SLIDA (which came under the purview of the Minister, Jayawickrema) were no longer required and he was reverted back to his original work at the Surveyor General's Department and prohibited from any lecturing at SLIDA. After a year he was transferred to the "pool" at the Ministry of Public Administration on the grounds of inefficiency and incompetence. Simultaneously, he was also placed on compulsory leave and asked to show cause within 30 days as to why he should not be retired on the grounds of general inefficiency. Eventually, on $2^{\text {nd }}$ October 1984, Perera was informed in writing by the Secretary of the Ministry of Public Administration that he had been compulsorily retired with immediate effect from public service on the ground of inefficiency. At that time, he had another nine more years of service before normal retirement.

Since all the disciplinary actions against him were based on the Minister's personal grudge, Perera sought Supreme Court intervention for redress for breach of fundamental rights, under Articles 12(1) and 14(1g) of the Constitution. Article 12(1) states,

All persons are equal before the law and entitled to the equal protection of the law. Article 14 (1g) states:

Every citizen is entitled to the freedom to engage by himself or in association with others in any lawful occupation, profession, trade, business or enterprise.

Source: Weerasooria, 2004, pp. 347-357 
Although Perera sought redress under Article 14(1, g), at the hearing his lawyer argued entirely on breach of Article 12(1).

A minority of the SC (three out of nine, including the Chief Justice) decided that Perera was entitled to be reinstated with compensation. However, the majority did not believe that Perera proved any similar discrimination in the public service. Accordingly, his case was dismissed on technical legal grounds but all judges held that:

They regretted the way Perera was treated by all: the Minister and Secretary, of the Ministry of Public Administration, the Secretary of the Ministry of Land. ${ }^{51}$ and the Survey General,

The Minister had acted wrongfully in his personal anger over the dispute, which has nothing to do with Perera's work and conduct as a public servant,

All the disciplinary steps taken against Perera by SLIDA and the two Ministries were illegitimate and revealed a grave miscarriage of justice resulting in palpable abuse of power by top officials,

Perera's compulsory retirement for inefficiency was improper because the procedure was not followed. It was subjective, unreasonable, unjustifiable and not in good faith, and

The Secretary, Ministry of Public Administration, had misused the powers delegated to him by the Cabinet in exercising disciplinary control over the petitioner as a public servant and wrongfully terminated his service prematurely. The various steps taken to punish Perera, who was innocent of any wrongdoing as a public officer, constituted a grave injustice.

\footnotetext{
${ }^{51}$ Survey Department where Perera worked came under the Ministry of Lands at that time. On any matter a public officer should communicate with the Ministry of Public Administration through the Head of Department, and the Secretary of the relevant Ministry.
} 
This is only one case out of so many others which clearly shows how public officers were affected and suffered under unlawful decisions and punishments by the authorities and how politicians and top officials used the system to abuse power.

\subsubsection{District Development Councils (DDCs) ${ }^{52}-1980$}

Another reform attempt during the 1980s by the UNP government was the establishment of DDCs to give teeth to DMs already in existence and to meet Tamil interests.

There had been several previous attempts (Bandaranaike-Chelvanayakam Pact in 1957, District Council Bill in 1960, and Senanayaka-Chelvanakam Pact in 1965) to accommodate Tamils' interest (Wriggins, 1982). All failed due to resistance from the majority. The introduction of DDCs was the fourth attempt, and only one out of nine Commissioners on the Presidential Commission of 1979 favoured the government proposal.

Dr. H.A.P. Abeywardene, former GA, commented on this commission,

Presidential Commission on Development Council - Tennakoon Commission, wanted to establish Rural Councils in place of the village and Town councils. They identified 269 units. There were differences in finalisation of the report arising out of political differences and class differences, that type of parochial reasons. The President did not want to have 'rural councils'. He wanted to give those powers also to DDC. The Commission in their report recommended against it. Seven out of nine members including the chairman said, this is not workable and not reasonable to combine the local government functions with the central government functions, therefore they are not recommending it. One member i.e. A.J. Wilson didn't sign and Neelan Cheruchelvam supported the idea, signed it saying that this is the ideal. The President selected the one person's recommendation and accepted. The prestigious village councils which had been in the country for centuries were abolished with one stroke of pen (Interview, 15.02. 2008).

Nevertheless, the government passed the DDC Act in 1980 and the DDCs were established in 1981 (De Silva, 1993; Matthews, 1982). 52 'DDC' connotation is also used in the previous section to describe Divisional Development
Councils. 
Thus, the DDCs took over the functions of existing village and town councils. The DDC was composed of the District Minister, an elected Chairman and a Council. As mentioned, the DM was appointed by the President and he was not always from the district of which he was a MP (Ministry of Local Government Housing and Construction, 1981). A key feature of the DDC was that they were composed of elected MPs from the district (Ex-Officio members) and elected councillors (elected members).

Each Council had an Executive Committee which was comparable to a mini cabinet (Ministry of Local Government, 1981). It was composed of a Chairman and two other members appointed by the Minister of Local Government in consultation with both the Chairman and DM with the approval of the President (Matthews, 1982). This Committee was headed by the DM. The main purpose of this Committee was to reduce any conflict over development activities between the DM (a Presidential appointee) and the DDC (which was popularly elected) (Wriggins, 1982). The Committee was responsible for carrying out executive functions of the district while the DDC as a whole engaged in legislative tasks. Therefore, the DDC had to depend on the Executive Committee in preparing and implementing annual District Development Plans, for which funds were provided by the central government, and over fifteen development functions in consultation with the relevant line ministries. This created room for controversy.

In order to assist the DDCs Gramodaya Mandalayas (GMs) and Pradeshiya Mandalyas (PMs) were established. The GMs were composed of Chairmen of voluntary organisations at village level recognised by the State and public officials at village level, while the PMs were composed of the Chairmen of GMs and government officials within the AGA division. The Chairmen of PMs were elected from among these representatives. The PMs decided the priorities of development proposals recommended by the GMs and referred them to the DDCs (Ministry of Local Government, 1981). According to Dr. Abeywardene, former GA, "as a result, Voluntary Organisations came up overnight, like mushrooms" (Interview, 15.02.2008). 
In the initial stage these DDCs were received by the locals with a lack of enthusiasm, but the DMs and Chairmen made them effective, even in the conflict areas in the North and East (De Silva, 1993). However, this lasted for only a short time. A lack of finance and authority for development work were the main complaints, especially from the DDCs in the North. The Tamil party claimed that "the DDC did not go far enough in decentralising power from the centre to the periphery in relation to the problem of the Tamil community" (Wijeweera, 1988, p. 187). Therefore, DDCs in Tamil Districts became inoperative soon after they were established. They frequently demanded more powers.

The other districts too did not welcome DDCs as a real need. This was mainly because there was less autonomy for their operation. For example, in all sections of the DDC law there was a need to consult central ministries on matters of the DDC. For example, Section 35 of the DDC Act required the DDCs to consult line ministries in the formulation of the district plan. Section 44 required the DDCs to get the final plan approved by the Minister of Local Government, Housing and Construction ("Development Councils Act No. 35", 1980). Section 25 and 27 required the Council to get the approval from the Minister of Local Government with the concurrence of the Minister of Finance to raise taxes, rates or other charges locally, to borrow within SL, and to negotiate loans directly with external lenders. There was also a provision for the dissolution of an Executive Committee that failed to relate to the appointed DM. So DM (as an extension of the presidential arm) had powers to dissolve the council if there was evidence it was incompetent (Matthews, 1982, p. 1121). Thus, sabotage from the centre was inevitable (Wriggins, 1982).

The involvement of the DM in the Executive Committee of the DDC was another issue because he was the representative of the Central Government in a local body. Another weakness was the lack of genuine people's participation in formulation of the development plan. The three-tiered structures, consisting of the GMs at village level, PMs at division level and DDC at district level, theoretically created a sound base for people's participation, but some research showed that it did not happen in practice (only 7 out of 355 proposals submitted by the GMs reached DDC via the PMs) (Gamage, n.d). Most GMs, therefore, later became inoperative for this reason. Further, the local NGOs had been dominated by the village elites so they did not 
genuinely represent the ordinary people. Another problem was that DDCs were highly dominated by the ex-officio members, MPs. The continuous dependence on the centre, along with these problems, made DDCs 'a dead letter' (Wijeweera, 1988). However, the politicians gained much power in the district administration over the bureaucrats with the establishment of the DDCs. The GA was held accountable for the political decisions in the district as the Chief Accounting Officer. Although, the village and town councils were abolished, their staff were absorbed into the new setup; therefore the staff were not badly affected by the reforms. But they were under the direct control of the political leadership.

All these decentralisation efforts discussed so far, DPA, DM, and DDC have several implications on public administration which will be analysed further in Chapter 7. They created complex problems in the political and administrative arenas and produced negative outcomes.

\subsubsection{Privatisation}

Another administrative reform initiative of the 1980s was the privatisation of PEs. In the SL context, privatisation is the "transfer of management and/or ownership of property from the public sector to private sector' (Central Bank, 1998, p. 215). It was initiated by the UNP government during 1977-1994. The fiscal difficulty and other economic drawbacks called for radical changes to the economy (Dunham \& Kelegama, 1997). The key motivations for privatisation included improving efficiency and productivity through private capital investment, technology, and expertise. It also intended to reduce the burden of the government budget (Central Bank, 1998) and to maximise revenue to the government from assets sales in order to repay public debt.

The government had taken several steps from the early 1980s in preparation for privatisation. These steps were: abolishing public sector monopolies, improving commercial orientation for PEs, transferring management of some of loss making PEs to the private sector under a contract system, and closing down some non-viable enterprises (Salih, 2000). In preparation for privatisation, the economy was reformed 
in 1977. Accordingly, the 1977 budget devalued the rupee and introduced a managed float for the exchange rate, removed qualitative restrictions on imports and relaxed rules on domestic pricing. Interest rates were also adjusted (Adam et al., 1992, p. 300). In addition, in 1979 trade liberalisation was introduced in the industrial sector. Furthermore, in order to stimulate non-traditional export goods and facilitate trade liberalisation, the Greater Colombo Economic Commission and Free Trade Zone were established (Central Bank, 1998). In 1987, the Public Enterprises Division was established in the Ministry of Finance and enacted the Public Corporations Act No. 22 of 1987 for the conversion of government owned business units into public corporations and the Public Company Act No. 23 of 1987 for the conversion of public corporations and government owned business units into public companies (Kelegama, 1992, Salih, 2000).

\subsubsection{Reform Experience}

Initially, the privatisation programme was conducted in an ad hoc manner. The responsibilities for handling the privatisation process have undergone many changes until 1995. A number of line ministries carried out specific reform measures in their PEs during 1980-1986 before the policy was officially declared in 1987. For example, the privatisation of industrial enterprises was carried out by the Ministry of Industries (selling of SL Rubber Manufacturing Company, Co-operative Whole Sale Enterprise, Noorani Tiles Ltd., Shaw Industries Ltd., and Vijaya Tiles Ltd), while textile sector divestures were dealt with by the Ministry of Textiles (Adam et al., 1992). These companies collapsed soon after the sale (Public Enterprises Reforms Commission, 2004). The Commercialisation Division of the Ministry of Finance also did some of the divestiture. In 1996, the Public Enterprises Reform Commission was established by enacting the Public Enterprises Reform Act No. 1 of 1996. In 1996, the government enacted the Rehabilitation of Public Enterprises Act No. 29 of 1996 due to several failures.

After the policy of privatisation was officially declared, the first candidate for privatisation was United Motors Ltd. (Adam et al., 1992). The transaction was handled by the Commercialisation Division (CD) of the Ministry of Finance. In 1989, United Motors was converted into a public Company, the United Motors 
Lanka Ltd., with a share capital of SLRs 100 million (SLRs 10, a share) through public offering. However, the government could sell only 3.3 million shares, of which $75 \%$ were taken up by two state-owned insurance companies. However, 5.7 million was left with the underwriters, the majority of whom were governmentowned institutions (Adam et al., 1992, p. 310). Ninety-five percent of shares were once again in the hands of the public sector. In this way, the first attempt of privatisation did not make any substantial change in the ownership as expected in theory. Thus, it was unable to achieve the anticipated objective of privatisation.

Nevertheless, many other public enterprises which were not economically viable or could not be made viable were closed down or sold to the private sector. Moreover, as of 2004, around 100 enterprises were transferred to private hands (Central Bank, 1998).

In the SL context, the legislation and policies that were introduced did not fully specify the details of the methods of privatisation. Therefore, different methods were used. SL experience shows that it was more reliant on asset sales, management contracts and contracting out public services over the other forms of privatisation. In addition, public floats were also used in order to have a wider base for share capital. There is some evidence that it used employee buyout in a very limited way, to please workers and to avoid resistance.

\subsubsection{Regulatory Framework}

The liberalisation of the economy and the subsequent reform in the PEs created a need for a competition policy and regulatory mechanisms to safeguard the interests of the consumers and competitors in the market. Although the need was urgent there was no enthusiasm from the policy makers to formulate effective competition policy and regulatory systems to assist the reform process. In the area of regulation the Fair Trading Commission was established in 1987, a decade after the trade liberalisation (Knight-John, 2002). The competition policy is yet to be formulated. However, the

government has attempted to formulate sector specific regulatory principles, for example, the Telecommunication Act No. 25 of 1991, and the National Transport Act No. 30 of 1988. Accordingly, two sector specific regulatory bodies were 
established: Telecommunication Regulatory Commission and National Transport Commission. Neither of them was independent or effective.

The impact of privatisation on the government and the economy as a whole is mixed. The following section discusses the reforms outcome in detail.

\subsubsection{Reform Outcomes}

\section{Economic Outcomes}

Privatisation has brought several positive and many negative outcomes to the economy. According to the Central Bank (1998, p. 219), there were many advantages in privatisation: reduced burden on the government budget and the size of public debt, and improved efficiency, productivity and management. In addition, employees became shareholders, and the employees who had voluntarily retired received attractive compensation benefits. Furthermore, several privatised PEs were purchased by reputed foreign companies helping to improve the foreign investor confidence in SL. However, the negative effects were ignored by the Central Bank in this report.

Table 8 below illustrates the privatisation income as a percentage of the GDP in some selected years. Accordingly, the divestiture proceeds gradually increased from 1990 onwards until 1997 and then dropped considerably. The highest amount was recorded in 1997. However, the overall net proceeds as a percentage of the GDP are very small, below 1\%, except in 1997. Nevertheless, many PEs are currently operating in various sectors in the economy, around 221 accumulating losses which were around 2\% of GDP in 2000 (Knight-John \& Athukorala, 2005). This indicates that the burden of PEs as a percentage of GDP is higher than the revenue gained through the privatisation proceeds. In addition, this data shows that whatever the merits and demerits of privatisation, it has not improved the financial position of the government to a significant level. 
Table 8: Gross and Net Privatisation Proceeds as a Percentage of GDP, Selected Years

$\begin{array}{cccc}\text { Year } & \begin{array}{c}\text { Gross proceeds } \\ \text { (SLRs million) }\end{array} & \begin{array}{c}\text { Gross Proceeds } \\ \text { (percent of GDP) }\end{array} & \text { Net Proceeds (GDP) } \\ 1990 & 588.3 & 0.2 & 0.10 \\ 1992 & 4,423.5 & 1.1 & 0.55 \\ 1993 & 4918.6 & 0.9 & 0.45 \\ 1995 & 3,124.6 & 0.5 & 0.25 \\ 1996 & 4,542.0 & 0.6 & 0.30 \\ 1997 & 22,396.0 & 2.5 & 1.25 \\ 1998 & 4,516.0 & 0.4 & 0.20 \\ 2001 & 8,601.0 & 0.6 & 0.30\end{array}$

Source: Knight-John and Athukorala, 2005, p.399

One of the positive effects of privatisation was that it generated permanent revenue sources by way of lease rent, income tax, and dividends while reducing the subsidies to loss-making enterprises (Salih, 2000). Furthermore, some of the privatised firms also benefited from technological upgrading and new capital. For example, in the plantation sector, since 1999, average capital investment was Rs.500 million per company. SL Telecom has invested more than 40 billion in developing communication infrastructure during 1996-2001. Colombo Gas Company Ltd. (Shell) has invested around 7 billion after privatisation (Knight-John and Athukorala, 2005). However, a study conducted by the World Bank on infrastructure privatisation in 2000-2001 illustrated that capital investments, measured in terms of capital expenditure to sales and capital expenditure to assets have decreased after privatisation. Table 9 below indicates that except for the Telecom, Colombo Gas Company and Air Lines, capital investments to sale have dropped after privatisation. In regard to capital expenditure to assets, all three companies have failed to adhere even to the status quo. Therefore, in order to make a general judgment there should be an overall inquiry. 
Table 9: Capital Investment in Selected Privatised Companies

Company

SL Telecom Ltd

Capital expenditure to sales

Capital expenditure to assets

Colombo Gas Company Ltd

Capital expenditure to sales

Capital expenditure to assets

SL Air Lines

Capital expenditure to sales

Capital expenditure to assets

\author{
Pre-privatisation \\ (mean)
}

0.670

1.420

0.386

0.180

0.386

0.179
Post-privatisation (mean)

0.980

0.310

1.050

$-0.370$

0.051

$-0.335$

0.060

$-0.120$

0.089

0.059

Source: World Bank, 2001 (as cited in Knight-John \& Athukorala, 2005, p. 403)

Nevertheless, the impacts of reform on these industries and the economy in general have been considerable. With regard to telecommunications, the SLT has been one of the key players in the economic growth in recent years. Its annual growth rates were $23.1 \%$ in $2001,19.3 \%$ in 2002, and $24.5 \%$ in 2003 (Knight-John \& Athukorala, 2005, p. 43). Its tele-density in the fixed market rose from 0.73 in 1991 to 5.1 in 2004 while mobile penetration increased from 0.01 to 11.4 over the same period.

Privatisation also contributed to the development of the Colombo Stock Exchange by bringing in 12 new companies into the stock exchange, and increasing the number of listed companies from 226 to 236 during 1996-1997 (Salih, 2000, p. 184). This was mainly driven due to the foreign investment attracted by privatisation.

Despite some positive effects, there were more negative effects on the economy due to privatisation. According to the Annual Report of the Public Enterprises Reform Commission in 2004, out of 98 privatised PEs, 17 divestitures collapsed after privatisation. In terms of proportions about $16 \%$ of the privatised companies have failed to continue their services and closed down, leaving their employees abandoned without compensation or even salaries for many months. Some of these unsuccessful 
ventures were rehabilitated in 1997 at the cost of SLRs 1 billion (Knight-John \& Athukorala, 2005).

In addition, the government has given exclusive concessions (tax holidays, income tax deviations, and price increases) to several privatised firms, for example Telecom, Shell Gas and Prima. This hindered the objective of privatisation. The economy, consumers, and competitors were all negatively affected due to this situation. In addition, the lack of effective regulatory mechanisms and a general competition policy prevented the effective operation of privatisation. If these mechanisms were organised earlier, the economy, consumers, input suppliers and general public would have been better off from the privatisation.

Another negative effect was that the Government under-priced shares of the firms with a view to promoting popular participation in the privatisation programme to minimise new investors' financial risk, and to avoid over-burdening the domestic capital market. This gave the government a high cost because share prices of many privatised firms increased soon after privatisation (Knight-John \& Athukorala, 2005). This situation left a negative view about privatisation in people's minds.

The recent COPE report, discussed in Chapter 4, investigated many irregularities in the privatisation process. The most controversial discoveries of the COPE were the sale of shares in SL Insurance Corporation and Lanka Marine Services Ltd (a bunkering firm attached to the state-owned Ceylon Petroleum Corporation) to SL conglomerate John Keels Holdings (JKH) in 2002. Since the government did not take any action against these incidents, a leftist former MP and Present Senior Advisor to the President, Vasudeva Nanayakkara, as a private citizen, filed fundamental rights cases in the SC.

In the Lanka Marine case the former Chairman of the Public Enterprises Reform Commission and the Secretary to the Treasury, Dr. P.B. Jayasundara, was found guilty of neglecting to act in the interest of the government. The SC ruled that he acted arbitrarily and exceeded his authority. The Court also found that JKH Chairman, Susantha Rathnayaka and Jayasundara had worked in collusion to give illegal advantages to JKH adverse to the public interest ("SL rocked", 2008). The 
Court said the entire privatisation exercise was flawed and was against the liberalised plan recommended by the Cabinet.

The SC ordered Dr. Jayasundara to pay SLRs. 500,000 (which is the highest amount of compensation to the State ever in a fundamental rights case) on $21^{\text {st }} \mathrm{July}, 2008$, in relation to the transaction of Lanka Marine Ltd. This led to a serious ethical issue: Dr. Jayasundara as a civil servant who had been fined by a court of law. This was highlighted by the same former MP, Vasudeva Nanayakkara. His lawyers sent out a Letter of Notice to the Central Bank Governor with regard to Jayasundera's continuation on the Monetary Board in the light of the adverse judgment, because under Monetary Law Act No. 32 of 2002, the Treasury Secretary is a member of the Board. Eventually, Dr. Jayasundara under pressure tendered his resignation to the President on $28^{\text {th }}$ July, 2008 but it was only accepted on the $17^{\text {th }}$ September, 2008 in advance of the Parliamentary debate on the matter scheduled to be held on the $23^{\text {rd }}$, September. However, to date this is the only officer to be fined guilty in relation to privatisation matters.

Similarly, the SC found irregularities in the privatisation of the SL Insurance Corporation. The Court declared the privatisation null and void, claimed it had been privatised contrary to tender procedures during the UNP government in 2002. The Court directed that all shares sold to the private entrepreneur be vested back with the General Treasury (“Outgoing Sri Lankan”, 2009).

In addition, the former President Kumaratunga was fined in relation to privatisation of "Water's Edge" by the SC and the buyer was ordered to return the property to the government. The Court mentioned that the President had misled the Cabinet by indicating the property would be used for a public golf course but it was sold to a person close to the President. In all these cases the country lost millions. Vasudeva Nanayakkara requested the government to appoint a Presidential Commission to investigate irregularities in another 41 past privatisation deals. He mentioned that he has evidence on irregularities of those privatisation deals where the country lost billions. These actions have far-reaching adverse implications on public administration today. 


\section{Effects on Employees}

There are several positive effects on employees: employees became shareholders of the privatised companies, for example, United Motors Ltd and Buhari Hotel Ltd had given $5 \%$ and $80 \%$ of shares to employees respectively (Knight-John \& Athukorala, 2005; Salih, 2000). The other merit was that employees enjoyed windfall capital gains on shares due to undervaluation in the early stage of privatisation. For example, Ceylon Oxygen Ltd and Shell Gas Ltd share prices increased after privatisation (Salih, 2000, p. 186). Employees who voluntarily retired before the age of retirement received attractive packages of benefits, such as Lanka Loha (a key industry in steel) (Salih, 2000).

The main negative effect was employee redundancy. Since most PEs were overstaffed when privatisation was introduced, a considerable number of employees lost their jobs. A study done by Knight-John and Athukorala (2005) illustrates that many workers lost their jobs due to privatisation. Table 9 provides direct employment effects of privatisation for selected companies. According to Table 10 the SL Telecom, SL Air Lines and National Development Bank have increased their staff after privatisation whereas others have reduced. The Colombo Gas Company reduced their staff by two-thirds and the Lanka Ceramics Ltd reduced their staff by half.

Table 10: Direct Employment Effects of Privatisation for Selected Companies (Average Employment)

$\begin{array}{lclll}\text { Company } & \text { Year } & \begin{array}{c}\text { Before } \\ \text { privatisation }\end{array} & \begin{array}{c}\text { After } \\ \text { privatisation }\end{array} & \text { Change } \\ & & 7,599 & 8,499 & 900 \\ \text { SL Telecom } & 1997 & 4,358 & 4,908 & 550 \\ \text { SL Air Lines } & 1998 & 646 & 292 & -354 \\ \text { Colombo Gas Company Ltd. } & 1995 & 188 & 311 & 123 \\ \text { National Development Bank } & 1993 & 320 & 275 & -45 \\ \text { Caltex Lanka Ltd } & 1994 & 1,562 & 560 & -1,002 \\ \text { Lanka Salt Ltd } & 1997 & 38,786 & 33,367 & -5419 \\ \text { Total } & & & \end{array}$

Source: Knight-John \& Athukorala, 2005, p. 413

The other negative effect was that most of the redundant employees were unable to find alternative jobs or sustainable income sources due to non-expansion of the 
economy. This was particularly serious for non-skilled workers. In most cases the compensation package was not sufficient to reduce the welfare losses of the employees (Salih, 2000). Furthermore, "due to insufficient compensation and the non availability of sustainable alternative income avenues, retrenched workers faced a high psychological sense of dislocation and high susceptibility of old age poverty since gratuity has already been spent for other family commitments" (Salih, 2000, p. 193).

Essentially, there were few positive effects of reform for employees. Some of them became shareholders and enjoyed lucrative gains on shares and obtained attractive severance benefits. However, there was no uniformity in this process. More often, many employees lost jobs, received inadequate compensation and were unable to find alternative jobs. Employees suffered from a psychological sense of dislocation, and in few cases their remunerations were also curtailed.

\section{Effects on Investors}

Overall, privatisation had positive results for investors. In some cases investors gained exclusive rights in the market place which paved the way for maximisation of profits; for example, In the SL Telecom privatisation, Nippon Telegraph and Telephone Corporation (NTT) received a five year monopoly to provide international telephony and the Colombo Gas company also received a five year monopoly (Knight-John \& Athukorala, 2005, p. 405). The motive for this was to attract investors and make firm investment commitments for infrastructure development. In addition to exclusive rights, some investors benefited from tax holidays on income tax; for example, expatriate staff at Prima Flour Company Ltd were exempt from income tax for five years and enjoyed tax holidays for twenty years (Knight-John \& Athukorala, 2005) as in Lanka Marine Ltd privatisation. In the case of air lines, the buyer, Emirates Air Lines was given the opportunity to pay US\$ 45 million out of US\$ 70 million upfront, and the balance to be paid over 30 months (Knight-John \& Athukorala, 2005). 
In an interview, Daya Liyanage, Head of the National Procurement Agency, said,

SL is the only country which gave government loans to private sector to buy Public entities (Interview, 07.01.2008).

Due to exclusive rights granted to the incumbent firms with the privatisation, other investors were affected, for example, competitive investors in the telecommunications sector (Knight-John \& Athukorala, 2005). Overall competition in the country is limited due to lack of competition policy and lack of effective regulatory mechanisms, along with the protection of monopoly.

In summary, the investors benefited the most from privatisation and in a variety of ways. In the utility sector, due to large investments, the investors gained exclusive rights over the others including monopoly power in some markets, tax holidays, and income tax exemption. In the privatisation of Air Lines the investor gained lucrative incentives. However, a group of investors were negatively affected due to exclusive rights of the incumbent operators.

\section{Effects on General Public/Customers}

Effects of privatisation on the public are mixed. There were a few benefits to the public in general. They benefited from the share ownership although this was mainly confined to the wealthy urban population (Knight-John \& Athukorala, 2005). The public have the chance of receiving services quickly, without delays as in the case of PEs, for example, the telecommunication department took over one year to establish a land line, but after privatisation it was reduced to a couple of days. Similarly, consumers now have many choices due to the availability of a variety of goods and services in the market such as mobile phones. Due to the injection of new capital and technology through privatisation, consumers have better quality products which have improved their living standard to a certain extent.

However, privatisation also has some negative effects on the public. Removal of state subsidies and price increases have adversely affected consumers, for example, bus transport (Knight-John \& Athukorala, 2005). Underpriced shares of the privatised firms have caused tax payers to lose out at the expense of new owners. Furthermore, due to the exclusive rights granted to some privatised firms, customers 
suffered from price hikes and non-access, for example, in the SL Telecom privatisation the government entered into an agreement with Telecom which allowed Telecom to increase the domestic tariff. Accordingly, during 1998-2002 telephone charges increased: $1998-25 \%, 1999-25 \%, 2000-20 \%, 2001-15 \%, 2002-15 \%$. The other fixed telephone operators also followed the same procedure so that the consumers were negatively affected (Knight-John \& Athukorala, 2005). Similarly, gas consumers were also largely negatively affected due to price increases by the gas firm after privatisation.

Furthermore, people as the owners of the PEs lost their assets and the ownership due to privatisation, without proper compensation by way of fair prices for goods and services, or better quality services and products. In addition, in some cases tax payers' money was spent to rehabilitate some of the privatised firms in the interest of their employees.

In summary, despite many failures, PEs reform experience is significant. Privatisation was highly pushed to the forefront in the midst of the uncertainty in the country, with high tension caused by the ethnic violence in the north and the JVP violence in the other parts of the country with many strikes. Many researchers (Kelegama, 1992; Knight-john \& Athukorala, 2005; Salih, 2000) have concluded that overall the positive outcomes of privatisation outweigh the negative outcomes. However, whatever the merits and demerits of the reform, the SL experience shows that it was not able to bring remarkable revenue to the government as expected due to many flaws in the privatisation process. However, around 221 more public enterprises currently drain around 2\% of GDP annually for their survival. This suggests that future reform in this sector is critical.

\subsubsection{Administrative Reform Committee (ARC) 1986/88}

As mentioned in the previous section, during the 1980s radical economic reforms had been introduced by the UNP government by deregulation, liberalisation and then privatisation of PEs in the country. However, at the early stages, the economic reforms were not supported by the administrative reforms in a systematic and 
conducive way. Having recognised the necessity of administrative reform in support of the economic reform, and to improve the efficiency in the public sector, the ARC was constituted by the President in October 1986, consisting of eight members with outstanding experience in public sector management.

This committee suggested an overhaul of public administration, but those recommendations were not fully implemented. In fact those recommendations were very important from the perspective of this thesis, thus warranting a chapter of their own. Hence, the next chapter is devoted to discussing this initiative in detail and the reasons behind the non-implementation of its recommendations.

\subsubsection{Provincial Council System (PCs) -1989}

The establishment of the PCs can be considered as devolution ${ }^{53}$ of powers to the periphery. The existing DDCs which were discussed earlier in this chapter were about to collapse due to lack of autonomy to carry out their functions from their inception. However, by September 1982, the ministers of the Central Government had delegated some of their powers to DMs just before the Presidential election (De Silva, 1993). This did not make any difference to the Tamils who live in the North because their DMs were outsiders to them and also Sinhalese MPs. The Tamils want their own representative as their DM with more autonomy. Against this backdrop, their campaign for regional autonomy became more violent.

The evolution of PCs was totally driven by external elements in President Jayewardene's second term which began in 1982. In July 1983 the ethnic conflict of the country became extreme with the killing of 13 soldiers by the Tamil militants in the North ${ }^{54}$ (Singer, 1990). The Sinhalese attacked Tamil shops and homes, and the violence spread from Colombo to other parts of the country, culminating in a civil war between the government and the military groups in the North and East. The conflict gained increasing international attention after this incident. The Tamil

\footnotetext{
${ }^{53}$ In SL context, devolution means transferring political and administrative decision-making authority from central government to elected bodies at lower levels.

${ }^{54}$ Prior to this time Tamil militants had killed many Sinhalese, Muslims, and robbed banks (Singer, 1990).
} 
militants and refugees acquired "sympathy, asylum, material benefits, and training in neighbouring India, especially in the Indian province in closest proximity to the island, Tamilnadu" (Shastri, 1992, p. 724).

In particular, the Tamil expatriate and the Tamil Co-ordinating Committee in London and similar organisations in the U.S., Canada, and West Germany carried out campaigns, supporting 'Tamil Eelam' and opposing the SL police (Matthews, 1982). Against this background by 1983, ethnic problem in SL, resulted in the emergence of five or more military groups ${ }^{55}$ in the North and East (Marasingha, 1988). According to Singer (1990, p. 417);

After 1983, the Indian Central Government, Indian intelligence (the research analysis wing- RAW) and Tamilnadu State Government all supported one or another of these militant groups with arms, money, training, and most important of all for a time, safe sanctuary ${ }^{56}$...Between 1987-89, Indians exploited the hatred of all these groups for each other by building up the EPRLF as an indigenous political alternative to LTTE, and they have even used its people to help hunt and kill LTTE members

The LTTE started to kill members of the other Tamil military groups, and drive Sinhalese out from the East and thousands of innocent people were killed. The LTTE wanted to be the sole Tamil militant group and rule their own independent country (Singer, 1990).

From 1983, SL security forces were well-trained and professionally developed, increasing their size by $250 \%$. They counter-attacked LTTE bases in the North (Singer, 1990). Tamil residents in Tamilnadu (India) sympathise with Tamils in SL so that any attack on SL Tamils was seen as an attack on all Tamils, so the Indian Government felt that they had to intervene to solve the problem. The Indian Prime Minister, Rajiv Gandhi pressed the Tamil militants to talk to the SL government for a peaceful solution.

\footnotetext{
55 The five organised military Tamil groups were People's Liberation Organisation of Tamil Eelam (PLOTE), Tamil Eelam Army (TEA), Tamil Eelam Liberation Organisation (TELO), - these three were joined together and formed Eelam People's Revolutionary Liberation Front (EPRLF). The other two groups are Liberation of Tigers of Tamil Eelam (LTTE) and Eelam Revolutionary Organisation of Students (EROS). They did not join into one single group but formed a common military axis and thereby served each other to complement the joint war effort. In addition, to this there was a noncombative research unit set up in Madras called Protection of Tamils from Genocide (PROTEG) (Marasingha, 1988, p. 564).

${ }^{56}$ See Singer (1990). He personally met with all the major militant groups in Madras in both 1985 and 1987 and they confirmed this was true although India denied it.
} 
As a result, in late 1983 until end of 1984, the SL government and the representative of the Indian government negotiated with the Tamil United Liberation Front for a political solution to the problem. By this time they totally rejected the DDCs on the ground that they needed 'traditional homelands' (De Silva, 1993). They proposed a supra-provincial entity encompassing the Northern and Eastern Provinces. President Jayewardene was persuaded to accept it with the support of the Indian Representative, but there was no support from the Cabinet and the governing party for this proposal (De Silva, 1993). Nevertheless, the government put forward the proposal at the All Party Conference. The Muslims strongly disagreed, since they would face problems with the dominance of Tamils in the East, because in the East Tamils were a minority of the population ${ }^{57}$ (only 40\%) (De Silva, 1993). A Buddhist opinion was to strengthen the existing DDCs. As such, at the All Party Conference on $30^{\text {th }}$ September 1984, a draft Bill was submitted enhancing power of DDCs on a wider provincial basis (De Silva, 1993). The TULF opposed it. The SLFP too did not participate at the discussion on the ground that the proposal would diminish the unitary structure of the country.

Despite these failures, in December 1984, the government again presented a draft Bill on a district and provincial-based administrative system which was again rejected by the TULF (De Silva, 1993). However, it is worth mentioning that provincial administration was proposed by the Donoughmore Reforms in 1927. This was not implemented during that period because transferring governing power from the British to the Ceylonese was more crucial at that time.

Nevertheless, the government again started diplomatic negotiations with the Indian Government which eventually led to a meeting between President Jayewardene and Prime Minister Rajiv Gandhi in June 1985 (De Silva, 1993, Rao, 1988). This meeting resulted in three months' cessation of hostilities and further negotiations with the Tamil militants. The negotiations between the SL Government and the LTTE were

\footnotetext{
${ }^{57}$ Tamils are mostly concentrated in the North. By the time of signing the Accord population in the Eastern province consisted of Tamils- $40.9 \%$, Moors $-32.3 \%$, Sinhalese- $21 \%$ and Indian Tamils $1.1 \%$. It is also pointed out that $38.2 \%$ of Tamils live outside these two provinces, especially in and around Colombo.
} 
held in Thimpu, Bhutan in July and August 1985. India acted as mediator but negotiations ended with no result (De Silva, 1993). Shortly after, other negotiations were held in New Delhi with Indian Government officials and the SL Government Officials. Following the Indian Union model was agreed upon. The core of this proposal was to establish PCs "within the framework of the country's constitutionally-entrenched unitary system" (De Silva, 1993, p. 118).

\subsubsection{Indo-Sri Lanka Accord}

Under pressure from India, and the increased violence, death and destruction on all sides of the country, President Jayewardene finally signed up the Indo-Sri Lanka Accord with Prime Minister Rajiv Gandhi in July 1987 to solve the ethnic problem and bring peace to the country by devolution of power (De Silva, 1993; Marasingha, 1988; Shastri, 1992; Singer, 1991). There was a disagreement with the Accord within the ruling UNP itself. The Accord immediately brought huge political repercussions. Violence erupted throughout the country in protest of the actions of the President and his invitation for Indian military personnel to the Island under the Accord.

The Accord specified obligations for the Indian and SL Governments, but not the LTTE since they were not a party to the Accord. Under the Accord the SL Government agreed to establish PCs in the nine provinces before 31 December, 1988 allowing the North and East Provinces to form one administrative unit temporarily, and allow people of the Eastern Province to decide whether they preferred to remain so linked or whether they wished to be separated, in a referendum to be held before 31 December 1989. However, the President had the sole discretion to postpone such a referendum, so the referendum was never held. It also agreed to recognise "the Northern and Eastern Provinces as areas of historical habitation of SL Tamilspeaking people" while recognising "SL is a multi-ethnic, multi-lingual plural society consisting, inter alia of Sinhalese, Tamils, Muslims (Moors) and Burghers" .The Indian Government also agreed to provide military assistance on the request of the SL Government to implement the Accord, deport all SL separatists from India and not let them use India as a sanctuary. 
Under the Accord, a cessation of hostilities was to take effect all over the country within 48 hours of the signing of the Accord, and all arms were to be surrendered by militants groups. The government invited Indian troops to help disarm the militants. These will not be discussed here in details since they are out of the scope of this study.

Although the necessary legislations were passed: the $13^{\text {th }}$ Amendment to the Constitution, the Provincial Councils Act, and Provincial Councils Election Act, the LTTE and the JVP violence in all parts of SL did not allow PC elections to be held as agreed. However, later PCs were established in 1988 for a period of five years. The SLFP boycotted the election (Shastri, 1992). On the Tamil side some groups, such as the EPRLF accepted the system of PCs and contested for the North East Provincial Council (NEPC) with the help of Indian Peace Keeping Forces (IPKF) (Shastri, 1992). The LTTE rejected the system as "inadequate" (Rao, 1988). UNP won all PCs except NEPC. The Tamil Party, EPRLF, dominated in the NEPC which was established in December 1988, later than the others due to security problems (Shastri, 1992).

The NEPC however, existed until June 1990. During its short life, it struggled to acquire more powers. Finally, its administration was taken over by the Government. Bradman Weerakoon, former Secretary to Prime Minister (2001-2004), in an interview said,

Most SL governments have shown an extreme reluctance to part with power. Survival is paramount for to be in is everything. To be out is to be nothing. This is so even today. President Premadasa saw that EPRLF and IPKF get together try to dominate power in the North. The IPKF marginalised LTTE, In the meantime, Wardaraja (Chief Minister NEPC) declared 'Unilateral Declaration of Independent' in 1990 and by March President Premadasa dissolved the NEPC on the ground that it violated the Constitution (Interview, 30.11.2007).

Accordingly, the PC system failed from the start. It should not be expected that any newly-created organisation will be fully functioning within a year or two. Furthermore, this system was too radical for SL and the initiation period occurred during a time of political instability. The problem with J.V.P was similar to LTTE; no government could concentrate on devolution to be effective in such environment. 
The EPRLF was in a hurry to acquire powers. Until now, the North PC has been operated by the government officials.

In summary, the PCs were established as a means of devolving of administrative and political power to the periphery, mainly with a view to solve the ethnic problem which lasted three decades in the country. The other fundamental purpose was to make the government's development effort meaningful and relevant to the needs of the people by making them partners in the development effort (Ministry of Public Administration, Provincial Councils, and Home Affairs, 1990). However, the main purpose has not been achieved due to multiple reasons. Regardless of any degree in devolving power people view PCs as 'white elephants,' another layer for bureaucratic and political malpractices and corruption. People's problems still remain with the people as discussed in the previous chapter. Although there is no need for decentralisation as in India because SL is a small country, there is a political need to do so. However, it seems that there is no national level consensus or a policy on devolution and political solution to Tamil strife even after the war is over in May 2009.

\subsubsection{Introduction of Performance Appraisal (PA) System}

The other reform initiative was the introduction of PA system by the SLFP government (1994-2000) in 1998. In the SLPS, personnel decisions such as employee promotions, salary increments, important postings, training and so on, were subjective judgements and were based merely on the recommendation of the Head of the Department. In particular, the recommendations for promotions were made in the form of confidential reports, hence the employee had no chance to see how the Head of the Department was evaluating him/her. In most cases these evaluations were mainly based on personal attributes, not purely on good or bad performance (personal observations). The lack of a proper mechanism for the evaluation of performance, and its integration with other elements in human resource management, have contributed to lowering performance standards, reducing morale, causing inefficiency in service delivery, delays, corruption, and increasing frustration within the public service. Therefore, it was felt that instead of making these decisions 
based on supervisors' subjective judgements, a well documented assessment can help the management to make reasonable and sound personal decisions.

The other reason underpinning the reform was that, as already mentioned, the public sector was highly criticised for not meeting the demands and aspirations of the people effectively. There was a view that the public sector was giving more attention to inputs and following rigid rules, regulations and processes rather than looking for outputs or outcomes (Hughes, 1994). The SLPS has faced similar criticisms. The timeliness and quality of services were not anybody's responsibility in SLPS because everybody receives his or her salary at the end of the month regardless of whether he or she performed during that period or not, unlike the private sector (De Alwis, 2000; Guiza \& Nem Singh, 2003). In the private sector, there are two main incentives for employees to work hard: dismissal or other punishment is likely to follow inefficiency, good work may bring speedy promotion regardless of seniority. In the SLPS both these incentives were practically absent. Dismissal for laziness or inefficiency is so difficult to follow except in the most glaring cases. Tolerating inefficient workers and poor performers until they retire, places a burden on the public sector. When there is no difference between good or bad performers in the form of rewards and punishments there is little incentive to work hard (De Alwis, 2000).

Therefore, the main drive for reform stemmed from the pressure for a greater accountability which is also an aim of public sector reform in general. So, performance appraisal can have a double advantage in the public sector where managers are being asked to achieve greater results for each dollar they expend on wage and salaries, and public servants are being held more accountable by voters and politicians (De Alwis, 2000). The other motivation for reform was to link performance to employees' promotions, salary increments and training. The current practice which discussed in Chapter 4 shows that none of these objectives have been fulfilled.

In summation, the reforms during the 1970s and 1980s were primarily based on the concept of decentralising political and administrative authority of the central government and the introduction of a PA system in the public service. It is evident 
that all these efforts failed due to lack of political and bureaucratic will to implement them effectively.

\subsection{Part III: Reform Initiatives from 1990 to 2000}

During this period there were a few reform initiatives in the country: invitation of UNDP and ADB missions, financial management reforms, re-establishment of an independent Public Service Commission, and creation of Management Assistant Service.

\subsubsection{UNDP Mission}

Despite the availability of the ARC report, in 1990 a UNDP mission was invited by the Treasury to develop a programme for improving public sector management. The Mission consisted of expatriates. Within three months they submitted a report and formulated a US\$ 1.3 million project. This was approved by the government (Nadarajah, 1997), and it established a Restructuring Management Unit (RMU) in the Ministry of Policy Planning and Implementation without considering the policy unit of the Ministry of Public Administration which was implementing the ARC recommendations at that time.

The RMU continued for three years with visiting expatriates and non-governmental personnel, but no governmental staff (Nadarajah, 1997; Wanasinghe, 1994). Therefore, this unit was not respected by the public servants. During its office the agenda of reform was itself changed according to the government priorities. Initially it worked in line with the UNDP programme and then shifted its focus on decentralisation to Divisional Secretaries at the request of the Secretary to the Ministry of Policy Planning and Implementation to support the decentralisation efforts. Then in 1992, again its attention was directed to the rationalisation of structures and cadres of central government ministries, departments and provincial ministries. Finally, the UNDP evaluation mission recommended terminating the project in 1994 due to its failure to contribute to the substantial changes in the public service. Consequently, another attempt towards public sector reform ended with no result. 


\subsubsection{ADB Team}

The SLFP government which was in power in 1996 attempted to reform the public sector by inviting international consultants from the USA and New Zealand under ADB sponsorship. This invitation was made on the direction by the then President Kumaratunga. The study focused on reorganisation of public administration structures, rationalisation of public sector cadres and introduction of results-based management systems and procedures. As such, there were six key components of this reform. They were: adaptation of strategic policy formulation and policy coordination to achieve policy outcomes more effectively; adoption of a resultoriented philosophy as the guiding management principle; separation of policy making, service delivery, and regulatory functions of government; realignment of responsibilities to support the goals of the government more effectively; training of staff to respond more effectively to the new environment and thereby realise their potential; and redeployment of surplus staff (Root et al., pp. 1361-1362).

This mission suggested establishing an Administrative Reform Management Division (ARMD) under the President and Management Council chaired by the President. The ARMD was responsible for the design of the detail of the reform and to direct and oversee the implementation of key reform recommendations. This was a new entity. It was supposed to be supervised by an Advisory Board on Administrative Reform consisting of three non-official members in addition to the existing ex-officio Committee of Secretaries to provide "intellectual and professional diversity" (Root et al., pp. 1361). The additional members included personnel from the private sector, and public sector with professional experience in administrative reforms. The Management Council was responsible for ensuring the development and implementation of strategic policies, thus its main role was to rationalise and make more coherent policies rather than an ad hoc existing mechanism.

These recommendations were accepted by the Government and ARMD was established to operate for a three-year period as recommended by the consultant. Within a short period some of their recommendations such as reduction in the number of ministries and streamlining of their tasks were implemented. However, "these reforms did not last long" (Root et al., pp. 1361). New ministries were created 
and a number of Cabinet Ministers increased. Consequently another attempt to improve public sector productivity ended up with no result.

It is pertinent to state that those recommendations were in fact not focused on real problems in SL's public administration given the history so far discussed this chapter. Those are all "business-as-usual" reforms. Can they be successfully implemented in the absence of a proper system of government? In other words, can they be implemented independent of engineering governmental reforms?

\subsubsection{Fiscal Management Reform Programme (FMRP) 2001}

Another reform in the recent past was the introduction of Fiscal Management reform by the UNP government which came into power in late 2001. The major underpinning of this reform was the economic contraction. SL's economy, for the first time after Independence, recorded a 1.5\% contraction in 2001 under the SLFP regime. Although the economy recovered later at the rate of $4 \%$ of GDP growth, the fiscal position was not sound with the increase of defence expenditure, weak tax administration, a narrow tax base and various tax incentives. In addition, the balance of payments problems led the exchange rate devaluations, and raising the local currency value of the external debt. As a result, the budget deficit reached $8.9 \%$ of GDP (excluding grants and privatisation proceeds) and public debt escalated to $106 \%$ of GDP in 2002 (ADB, 2004a).

In this context, with the assistance of the ADB the government formulated the Fiscal Management Reform Programme (FMRP). Although the unexpected general election in 2004 changed the government, the programme continued with the support of the new SLFP government.

This reform was based on three major pillars: strengthening fiscal framework under the Fiscal Management (Responsibility) Act; streamlining taxation policy; and strengthening of institutions in revenue administration supported by creating of a modernised revenue administration (ADB, 2004a). Accordingly, the Fiscal Management (Responsibility) Act was enacted. Under this Act the Minister of 
Finance is legally obliged to report the financial position of the government in the five stages as discussed in the previous chapter (Table 5).

This reform focussed on "improving tax administration, budget framework, public expenditure management and control systems, fiscal discipline, and fiscal coordination including supporting the groundwork for fiscal decentralisation" (ADB, 2004a, p. 11). This project was completed in 2008.

Accordingly, attempts were made to restructure and modernise Customs, Inland Revenue, Excise Departments, and the Ministry of Finance and Planning through improving systems and processes, enhancing human resource capabilities and complementing information technology improvements. Accordingly, around 1,200 officers from the above four organisations, and the officers of the Finance Commission and the Provincial Councils were given foreign training on subject areas of relevance, new organisational structures were adopted, and job descriptions were formulated. In addition, "tax holidays were rationalised and legal measures were taken to improve the tax policy regime, particularly to improve governance and also address issues related to tax avoidance and possible malpractices in the refund mechanism" (Ministry of Finance and Planning, 2007, p. 178). Similarly, features of result-oriented budgeting under a medium-term budgetary framework were introduced while establishing a revenue management IT system (Ministry of Finance and Planning, 2007).

This project was initially designed to establish a Revenue Authority by amalgamating those three departments but it failed due to employee resistance (ADB, 2004a). Therefore, the SLFP government suggested establishing a 'Unified Revenue Board' to coordinate common functions by giving more operational autonomy to those departments (ADB, 2004a) but no action has been taken in this context yet. In addition, the reform programme intended to establish an independent Public Debt Management Office which was dismantled with the change of government as mentioned in previous chapter (ADB, 2004a).

Under fiscal decentralisation the government recognised the gap between provisions to PCs under the $13^{\text {th }}$ Amendment to the Constitution and the genuine fiscal 
devolution (ADB, 2004a). Therefore, this project is expected to address the imbalance between the centre and the province and across provinces. However, the progress of these actions so far was not published, but could be seen in the previous illustration in Chapter 4.

However, this reform facilitates the improvement of transparency, accountability of the government, and introduces good governance practices. It tries to develop a result-oriented management culture in the SLPS. The Minister is legally bound to carry out specific tasks. Since the reform was built into the administrative system, whoever holds the portfolio of the Minister of Finance has to comply with the Act. It is mentioned that around 600 officers in the Inland Revenue Department have been promoted from Tax Collectors to Tax Assessors due to this reform (ADB, 2004a). Therefore, they benefited from the reform. Overall the reform appears to be beneficial to the country as a whole. However, it is too early to make a final judgment.

\subsubsection{The $17^{\text {th }}$ Amendment to the Constitution 2001: Re- establishment of Independent Public Service Commission (NPSC) and Other Commissions}

The evolution of the independent NPSC and other commissions in the public service has a long history. The ARC (1986/88) highly criticised the personal administration of the SLPS. It highlighted that "the recruitment and promotional procedure in the public service was subjective and subject to political patronage and decisionmaking”, thus strongly recommended establishing an Independent Public Service Commission (Administrative Reforms Committee, 1986/88). The Presidential Commission on Youth (1990, pp. 4-5) also repeated this recommendation, while emphasising that,

We would emphasise that there are certain functions and services in public life which transcend political differences and short term interests of political parties. Appointments to the public service is indisputably one such area. The representations made before us suggest an alarming degree of dissatisfaction in this sphere, and we have considered several avenues for improving the situation. The 1972 Constitution removed the power of appointment vested in the Public Service Commission and brought the responsibility for such appointments within the purview of the Cabinet of Ministers, thus triggering, with far-reaching repercussions, the process of politicisation. The Commission is strongly of the view that the reversal of this pernicious process is now an urgent necessity and that 
the Public Service Commission, together with other similar Commissions, should be given full autonomy to work out their internal systems of regulation with regard to appointments, transfer, disciplinary control and dismissal and appeals ...

This Commission also highly criticised the politicisation of civil society, including the public service,

The politicisation of civil society appears to have its origins in the political practices associated with parliamentary victories involving large majorities, beginning with the 1970 elections. These victories not only gave rise to an unprecedented level of postelection violence but also to the perception that the 'winners takes all.' As one representative before this Commission put it, "the winners always acted in a manner so as to give the impression that the supporters of the loosing political parties ceased to be citizens of this country". This attitude served, and continued to serve, to polarize civil society at all levels, giving rise to the belief that members of the ruling party and their supporters have the exclusive right to all the rewards and benefits that society has to officer (The Presidential Commission on Youth, 1990, p. 1).

The Youth Commission devoted a separate Chapter on De-politicisation of Civil Society and highlighted over-politicisation in four areas (a) the abuse of political power in the recruitment of personnel to the public service, (b) misapplication of political power in the granting of public contracts and licences to the supporters of the ruling party, (c) the abuse of political power in the undermining of existing democratic institutions, and (d) political interference in the day-to-day administration of government institutions.

Accordingly, the politicisation of society as a whole and non-consideration of the key recommendations made by both Committees by any government led to deterioration of all sectors of the country, especially the public sector which is a part of this unique society and the main area of this study. Eventually, in 1997, the Opposition UNP suggested the Parliamentary Select Committee on Constitutional Reforms to introduce independent Commissions for Elections, Police, and Public Service and to strengthen the Judiciary. Those interventions were also confined to deliberations without any fruitful result. Nevertheless, that party did not give up the idea and decided to consult the views of the public in order to push these meaningful reforms forward. Accordingly, a Committee was appointed by the UNP in 1998 to further consult the citizens on these issues and to find a meaningful outcome. 


\subsubsection{Committee on Citizen Consultation on Free and Fair Elections and De-Politicisation of Key Institutions}

The Committee on Citizen Consultation was established to achieve two objectives: firstly, to consult citizens on free and fair elections, secondly, to depoliticise key institutions. Ranil Wickramasinghe, Leader of the Opposition and the UNP, in his letter addressed to all religious dignitaries, recognised political parties, nongovernmental organisations, professional bodies, and other civil society groups, had described the purpose and objectives of the Citizens Consultation as follows,

This is a critical moment in the history of our country. The future of democracy and the multi-party system is under threat. Restoring public confidence in the electoral process has become an urgent necessity. I propose to convene a Consultation on Free and Fair Elections and Depoliticisation of key Institutions in our country for the establishment of an Independent Elections Commission, an Independent Police Commission, and an Independent Public Service Commission. This consultation will be ongoing process. A non partisan committee will be appointed to facilitate the process...(Committee on Citizen Consultation on Free and Fair Elections and De-Politicisation of Key Institutions, 1998, p. 1)

The Committee was composed of eminent personnel of the public sector, private sector and judiciary. K.H.J. Wijayadasa, former secretary to the Prime Minister and the President (1984-1994) served as convenor. The Committee took two months to complete the given mandate (14.09.1998-30.11.1998). In response to the Committee's publicity for seeking public views, it received large numbers of submissions from the political parties, trade unions, non-governmental organisations, people's organisations and individuals. This clearly shows the gravity of politicisation of key institutions, and the citizens' expectations for their depoliticisation. In their report the Committee (1998, p. 10) mentioned,

In the light of deteriorating law and order situation in the country, especially in relation to political violence, election malpractices and abuses, political interferences in the day to day administration and the victimization of political opponents, there is an urgent need for the depoliticisation of the major democratic institutions and processes.

This Committee proposed the removal of existing provisions from the Constitution thus 'freeing[d] the public service from the clutches of the Cabinet of Ministers and other politicians' and establishment of independent National Public Service Commission. The report further says that, 
It is obvious that an efficient bureaucracy requires selection on merit and not on political patronage. If the government is keen on restoring the pride, stability and resilience of the administration, then, the cabinet and the individual ministers must divest themselves of the powers they have taken over from the Public Service Commission (PSC). The PSC should be vested with the powers of appointment, promotion, transfer, dismissal and made accountable to Parliament. The members of the PSC should be selected by the Constitutional Council of Parliament to be appointed by the President or the appropriate appointing authority (Committee on Citizen Consultation on Free and Fair Elections and De-Politicisation of Key Institutions, 1998, p. 20).

The Committee also recommended appointing Secretaries to Ministries from among persons of ability and quality by the President with the prior approval of the CC.

In regards to the Police Service, the report highlights,

After independence, the police continued to pride itself in its impartiality. But after 50 years, the police have now become an instrument of the party in power to retain power violating democratic rights of the people. This process of politicisation has been going on for the last four decades. Political patronage now supersedes merit, efficiency and integrity (Committee on Citizen Consultation on Free and Fair Elections and DePoliticisation of Key Institutions, 1998, p. 11).

However, it is noteworthy to mention here, after establishing the Independent Police Commission as recommended by this Committee, this situation changed. In an interview Vijitha Herath, MP, JVP, said,

2004 general election was the best election in SL because of the independence in the Police Service (Interview, 18.01. 2008).

In regard to the election administration the Report said among other things,

Since the beginning of the election process in SL, there had been instances of election malpractices and abuses. However, in early days such abuses were confined, mostly to impersonation and sometimes to the prevention of voters from turning up at Polling Booths. The large scale abuse of the election process is a more recent phenomenon and manifested in its worst from during recent elections. Rampant thuggery, mass scale stuffing of ballot boxes, forceful eviction of polling agents of opposition parties and the creation of a fear psychosis by armed gangs were evident at these elections in fact, these elections gave rise to the fear whether free and fair elections can ever be held again in SL (Committee on Citizen Consultation on Free and Fair Elections and De-Politicisation of Key Institutions, 1998, p. 8).

Accordingly, the Committee made historical analyses of key incidents of politicisation which undermined public confidence in key public institutions and arrived at several key recommendations to improve the situation along with critical 
constitutional reforms. The outcome of this attempt was the $17^{\text {th }}$ Amendment to the Constitution in 2001 with a few modifications.

It is interesting to note that although the report was made available in 1998, the implementation of its recommendations did not materialise until 2001. The PA's first regime ended in 2000 (1994-2000). The general election held in October, 2000, once again established a coalition government by the PA, led by President Kumaratunga but it soon encountered problems due to withdrawal of support by one of its coalition partners, the Muslim Congress, in June 2001.This instability led to crisis in Parliament (Wijeweera, 2006). In terms of Article 70(1-a) of the Constitution, the President is barred from dissolving Parliament within the first year from the date of the general election that voted it in. Otherwise, a motion of no confidence has to be passed, and by convention the President would have no option but to call upon the Opposition Leader to form the Government, or the President can make use of his/her power to prorogue Parliament for a period not more than two months to gain time to work out a strategy.

The Janatha Vimukthi Peramuna (JVP) which was then seated in the Opposition took the opportunity to support the Government for a period of one year, subject to several terms and conditions. The Memorandum of Understanding (MOU) signed by the PA and the JVP on September 5, 2001, made the government tenure of office depend on implementing the provisions contained in the MOU, which created a "Government on probation".

\subsubsection{Government on Probation}

The most critical provision contained in the MOU which is relevant in this study was the enactment of a $17^{\text {th }}$ Amendment to the Constitution already drafted by the Opposition UNP (subject to essential modifications) on or before September 24, 2001, and the establishment of the CC envisaged in such Amendment before October 5, 2001 (Wijeweera, 2006, p. 104).

This timeframe of legislative endeavours in the MOU was significant in politics because the election was held in October 2000 and the President had the power to 
dissolve Parliament any time after October, 2001. The dates were fixed, forcing the Government to accomplish the agreed tasks before the President's power could be invoked. This position was reinforced by the JVP parliamentarian, Vijitha Herath,

The President Kumaratunga was forced to bring this amendment. This is one of the agreements we made to join the coalition. If not we could topple down the government at this period because it was on probation. Not only JVP, but also the Opposition, the Organisation of Professional Association, and other organisations gave pressure to make this happen (Interview, 18.01.2008).

The $17^{\text {th }}$ Amendment was taken up and debated in Parliament on September 24, 2001, which was the last date spelt out in the MOU. But the CC was not established by the due date of October 5, 2001 as prescribed in the MOU.

However, the enactment of the $17^{\text {th }}$ Amendment was welcomed by all the intellectuals because they viewed it as the introduction of a new political culture in the country.

Dr. B.S. Wijeweera, former GA, explained this situation, in an interview,

The 17th Amendment was a very rare display of parliament getting together for once and displayed the unity where they managed to put through the Constitutional Amendment after a lapse of 10 years, with a sole objective of curtailing the powers of President and abuse of that power. In that sense it was the one of the best pieces of legislation ever to have been passed by a contemporary Parliament (Interview, 09.01.2008).

In this scenario, the $17^{\text {th }}$ Amendment was remarkable in the history of SL's Parliament for three reasons. The first reason was that a minority party, the JVP, having 10 members in a House of 225, dictated this event in the legislature. It seems that this historical event would not have occurred in that regime unless the Muslim Congress had left the government and the JVP joined it, with demands contained in a MOU. It is said that the President herself did not like the reform. Therefore, minority parties played a key role to put forward the Opposition agenda.

The second reason was that it was passed without anyone voting against it, thus signifying a consensus among the main political parties (Wijeweera, 2006, p. 100). The present Constitution of 1978 had been amended 16 times, from its inception in 1978 to 1988 . That could have been done because the UNP Government which came into power in 1977, ruled until 1989 with more than two-thirds majority in the 
House. Articles 82(5) and 83 of the Constitution require two-thirds majority of the total number of MPs and, in some cases, there also has to be approval by the people at a referendum. After the introduction of the Proportional Representation Electoral System, no government has had that majority since 1989. In addition, this enactment was passed at a time when the government was in a precarious situation and in fear of losing even the simple majority, needed to pass the Annual Budget for the coming year (Wijeweera, 2006). As such this Amendment was absolutely remarkable.

The third reason was that, when analysing the objectives of all the Amendments to the Constitution (1-16), one can conclude that they were done merely to gain political advantages for the rulers. None were made to reduce any power vested with the Executive and to enhance the power of independent Commissions. On all of these three counts the $17^{\text {th }}$ Amendment was a significant landmark.

However, the Coalition Probation Government did not last long because the Government did not like the dictatorship of the minor party, JVP in Parliament. Some senior MPs of the Government crossed the floor, which compelled the dissolution of Parliament, followed by a general election in December 2001. The Opposition, who drafted the Bill, came into power taking the responsibility of its implementation.

The next section examines the objectives and the contents of the Amendment, the processes spelt out therein, how key players acted in the implementation of the reform and what factors so far underpinned its success or failure, in order to understand the gaps in the present system. This review will provide a better understanding of how future reforms should be shaped, avoiding such technical deficiencies, for the provision of better services in the $21^{\text {st }}$ century and to regain the neutrality in the SLPS.

\subsubsection{The Rationale}

The main rationale that underpinned the Constitutional Reform was to curtail the discretionary power of the President on key appointments of the public service (Auditor General, Election Commissioner, Inspector General of Police, Members of 
the PSC, Judges of the Supreme Court), as described in Chapter 3, because this power seemed to have been abused on several occasions when appointments had been made. According to Wijeweera (2006, p. 101),

This discretionary power was absolute (i.e. anyone could be appointed at the sole will of the President). There were murmurs of protest that this power was not absolute and that such power was necessarily restrained by conventions of good governance and ought to be exercised within limits. This issue came to a head when Dr. Shirani Bandaranaike was appointed to the Supreme Court.

According to Wijeweera (2006), this appointment was done by the President in 1996 outside the normal practice. The normal practice was, with a few exceptions, to appoint the members of the Appeal Court, Official Bar (Attorney General's and Legal Draftsman Departments) or Unofficial Bar with extensive legal practice, to this high office. The appointee, Dr. Bandaranaike, who lacked experience in practising law in Courts, was a university academic with intellectual attainments. Therefore, this appointment was challenged in the $\mathrm{SC}$, but there is a specific provision in the Constitution, that states 'any action by the President cannot be challenged in any court' (Article 35). This appointment was among several other things, one of the causes that triggered this Amendment.

\subsubsection{The Objective and the Contents of the $17^{\text {th }}$ Amendment to the Constitution}

The core objective of this Amendment was to alter the legal regime for the appointment, regulation of service and disciplinary control of Public Officers, including Police Officers, Judges and Judicial Officers and of certain Commissions that wield governmental power. It placed a restriction on the discretion vested in the President and the Cabinet of Ministers in relation to these matters and the exercise of that discretion subject to the recommendation or approval of the new body, the "Constitutional Council," (Hansard, September 24, 2001) which was discussed in Chapter 3. Thereby it minimised the opportunities for abuse of such power by the President. The other motive was to re-establish the independence of the NPSC and to introduce new Commissions: the Election Commission, and National Police Service Commission. 
The other motive was to give the public officials job security. Under the 1946 Constitution public servants held office 'at the pleasure of the Crown' whilst 1972 and 1978 Constitutions they held office 'at the pleasure of the Cabinet of Ministers'. Article 54 (1) of the 1978 Constitution stated that,

Subject to the provisions of the Constitution, the Cabinet of Ministers shall provide for and determine all matters relating to public officers, including the formulation of scheme of recruitment and codes of conduct for public officers, the principles to be followed in making promotions and transfers, and the procedure for the exercise and the delegation of the powers of appointment, transfer, dismissal and disciplinary control of public officers...all public officers shall hold office at pleasure.

Accordingly, Cabinet used to have a lot more powers than currently. The $17^{\text {th }}$ Amendment to the Constitution (2001) withdrew that pleasure principle by giving all the powers to the NPSC. This is a major initiative in the new constitutional change after Independence (Rathnasiri vs. Ellawala, CA No.16/2004). As such, the vast range of powers given to the Cabinet of Ministers relating to the public officers including the 'pleasure principle' by the former Constitutions no longer exists.

Accordingly, it was an attempt to insert a new formula to the Constitution of 1978 by introducing a new Chapter VIIA, immediately after Article 41, and repealing Chapter IX of the 1978 Constitution, which specified the provisions for the public service and substituting an entirely new Chapter IX, which came into effect on October 3, 2001.

As mentioned in Chapter 3 the CC was inactive from 2005 due to the nonappointment of its members by the President. This shows the legal shortfall in the Constitutional Amendment.

\subsubsection{Conflicting Issues in the Amendment}

The actual exercise of governmental powers in regard to the matters of the $17^{\text {th }}$ Amendment is different from what was envisaged by the Amendment. Those conflicting points are now being discussed in different forums. The first point of conflict between the Amendment and the actual practice was the executive power of the President. Although the objective of this Amendment was to curtail the absolute power enjoyed by the President on certain appointments (Judges of the SC, Court of Appeal, Attorney General, etc), there was no provision in the Amendment to make it mandatory (Wijeweera, 2006). "The SC determination" on the constitutionality of 
the Amendment was clearly stated by the Attorney General: "it is a restriction on the exercise of the discretion by the President,...there is no removal of the executive power of the President." Therefore, the Bill needed to be passed by the two thirds majority in Parliament. If there was a removal of executive power, in addition to the two-thirds majority in Parliament, it had to be approved by the people at a referendum, in conformity with other provisions in the Constitution. Article 3 of the Constitution states;

In the Republic of Sri Lanka sovereignty is in the people and is inalienable. Sovereignty includes the power of government, fundamental rights, and the franchise.

The provision of Article 3 is in certain respects interlinked with the provision of Article 4. Article 4 (b) stipulates;

Executive power of the people, including the defence of Sri Lanka, shall be exercised by the President of the Republic elected by the people.

Therefore, the executive power of the people is exercised by the President through the public officers and commissions that have been mentioned above. It is in this context that the President is vested with the power of appointment, in relation to these officers and bodies. The SC considered the constitutionality of the $17^{\text {th }}$ Amendment. The SC questioned whether the executive power of the President was removed by this Amendment. The Attorney General found that whilst it was reduced, it was not removed. Thus, the "real power of appointment is still with the President" (Parliament, 2001).

The second conflicting area is the powers of the Cabinet. Under 55 (3) of the Constitution the Heads of Departments are appointed by the Cabinet of Ministers "after ascertaining the views of the Public Service Commission". Accordingly, consultation should be made with the NPSC before the appointment is made. However, according to Wijeweera (2006), the Cabinet of Ministers who initiated the $17^{\text {th }}$ Amendment, have made appointments subject to the ascertaining the views of the NPSC and the NPSC views were ignored. It is a violation of the constitutional provision.

The third conflicting area is the composition of the $\mathrm{CC}$ itself. As mentioned in Chapter 3, the CC members are the PM, the Speaker, the Leader of the Opposition, 
one person nominated by the President and five jointly appointed by the PM and the Leader of the Opposition. Of this five three have to represent minority community interests. Thus, the first three are directly members of different political parties, and the rest may have some form of political affiliation. Therefore, their decisions can be biased. Also, the governing party has no chance to dominate the $\mathrm{CC}$. The failure to appoint one person from the minority parties for two years, lead to a situation in which the CC could not be established, clearly shows that there is a lacuna in the composition of the $\mathrm{CC}$ itself. It seems that some respects, the $\mathrm{CC}$ is a political authority, rather than an independent body.

The fourth conflicting area between the Amendment and the practice in reality is the provision in relation to the existing Commissioner of Elections. Article 27(2) reads as;

The person holding the Commissioner of Elections on the day immediately preceding the date of the commencement of this act, continue to exercise and perform the powers and functions of the office of Commissioner of Election as were vested in him immediately prior to the commencement of this act, and of the Election Commission, until an Election Commission is constituted in term of Article 103, and shall, from and after the date on which the Election Commission is so constituted, cease to hold office as the Commissioner of Elections.

The Election Commission has not been formed as mentioned above due to nonconsensus of the CC nominations and the President. Therefore, the Commissioner of Elections is in a desperate situation. He cannot retire even though he has already passed the retirement age. He made a very humble request to the incoming President, Mahinda Rajapaksa, to grant him retirement when he announced the presidential election results in 2005. To this day, his request remained unanswered (mid 2009).

In summary, the $17^{\text {th }}$ Amendment to the Constitution has some critical points that conflict with existing practices: the President's real power on certain appointments has not been withdrawn; Cabinet's real power has not been reduced in the case of appointments of HODs, the composition of the $\mathrm{CC}$ itself has some deficits, and the continuation in office of the existing Commissioner of Elections is problematic. 


\subsubsection{Introduction of the Public Management Assistants' Service (PMAS)}

The other reform initiative during the period of the 1990s to 2000 was the introduction of the PMAS. As mentioned in Chapter 3, the SLPS consists of many sub-services based on division of work which prevailed from colonial time. In 2004, five such services, namely General Clerical, Shroff, Book Keepers, Store Keepers, Typists and Stenographers, were amalgamated into a single service called PMAS (Ministry of Public Administration and Home Affairs, 2004 \& 2005). Staff in the clerical service are now required to have competency in working with other office tools in relation to his/her speciality. Officers in other services such as typists and stenographers absorbed into this service should also acquire skills in the performance of duties which have not been entrusted to them under the old system (Ministry of Public Administration and Home Affairs, 2005). As such, an officer needs to gain a variety of skills.

The main objective of the establishment of the PMAS is to create one service consisting of officers who are endowed with skills and knowledge on multi-duty systems in place of services which existed in government offices based on division of work. Under the new system it is expected to achieve: improvement of efficiency and productivity in the public service, improvement of speedy service delivery through improvement of multifunctional professional skills; ensuring job satisfaction; reduction in recurrent expenditure; and optimum utilisation of human resources, office spaces and equipment. Therefore, the staff attached to this service have to develop multi-duty skills.

However, the implementation of the reform was not without problems. Even after a lapse of two-and-a- half years from the introduction of the new system, it is observed that many public institutions are still confined to the old system. Some of the trade unions opposed this reform due to their vested interests and have taken legal action which is still pending (Ministry of Public Administration and Home Affairs, 2008). Similarly, existing staff of those services were reluctant to carry out multifunctions, saying that they do not possess necessary skills; for example, clerks resist doing typing and typists resist doing other work than typing. This is the main problem in the public service today, because the reform did not focus on skill development 
before the reform implements. This reform moves towards the NPM-type of reforms in the SLPS.

In summation, during the 1990 s and 2000 , the government reforms were confined to improving the public finance management system and the personnel management system in the public sector. The enactment of Fiscal Management (Responsibility) Act of 2003 was a remarkable achievement by which the elected officials were given clear responsibility to show results. This enhances good governance and public accountability. The $17^{\text {th }}$ Amendment to the Constitution has its own deficiencies and it is not as effective as expected by the reformers. This shows the political resistance to reforms.

\subsection{Conclusion}

This chapter examined the post-Independence public administrative reform initiatives by successive governments in SL from the 1950s to 2005. The principal aim of this examination was to identify the motivations and drivers of reforms, whether they were successes or failures, reasons for their failures, and consequences, in order to draw lessons from the past for future reforms. This examination illustrated the complexity and specificity of the SL situation beginning with the language reforms in 1956 which led to several other reforms later. This speculates how the piecemeal reforms of the 1970s and 1990s inevitably failed and how their effects still shape the SL political and administrative systems and therefore, must be accounted for in any future attempt to reform the public sector. This analysis provides a broad base for the argument that one cannot contemplate future reforms in SLPS unless one understands the full complexity and specificity of what has happened in the recent past. In particular, the conceptual diagram of this study illustrated in Chapter 2 developed by Pollitt and Bouckaert also shows that the effects of public sector reforms depend on the history, structure, culture, and political economy of the country. The SL experiences align with this argument of specificity and illustrates why public sector reforms prove to be impossible in SL. The past reform experiences of SL demonstrate that public administrative reforms cannot be successful without commensurate reforms in the political system of the nation. In other words, public sector reforms cannot be independent of the political reforms. 


\section{Chapter 6: Review of the Administrative Reform Committee (ARC) Report of 1986/88 - An Overview}

\subsection{Introduction}

During the 1980s and 1990s, many countries around the world, both developed and developing, embarked on vigorous and thorough re-evaluations of the role of the state and the public service. This was mainly driven by various factors including the growth and enhanced application of information technology, globalisation and competition, failures in the public sector service delivery mechanisms and strategies, economic crises of individual countries, emergence of new theories, increased intervention of outside consultants, and the impact of the World Bank, and International Monetary Fund's Aid and Structural Adjustment Programmes. Accordingly, many countries followed economic liberalisation and political democratisation during this era, SL was no exception.

Thus, a Presidential Administrative Reform Committee was established by President, Jayewardene, in 1986 to examine and report on reforms required in government ministries and departments with a particular reference to the distribution of functions, policies relating to human resources management and development, administrative devolution, financial management and administrative systems and procedures. The Committee comprised of nine Sri Lankans with strong backgrounds as eminent practitioners in the public and the private sector. H.S. Wanasinghe was the Chairman of the Committee while V.T. Navarathna, then Director, Sri Lanka Institute of Development Administration (SLIDA) served as the secretary to the Committee. Other members were B. Mahadeva, S.M. L. Marikar, Willie Mendis, R. Peris, Asoka Senanayake, S.K. Wickramasinghe, and Eraj Wijesinghe. The first two members and the Chair of the Committee were prominent public administrators from the Ceylon Civil Service. Willie Mendis was a University Professor and an academic administrator. Riency Peris was a medical doctor who chaired the Sri Jayewardenepura hospital at that time. The rest of the members were drawn from the 
private sector. Therefore, the Committee had a good mixture of multidisciplinary professionals drawn from both the public and private sectors.

The Committee undertook a comprehensive review of many aspects of the public administrative system in the country. In doing so, it invited representations from the public who were interested in sharing their views with the Committee on its agenda. It received 171 memoranda. Face-to-face discussions also were held with the representatives. In addition, the Committee had detailed discussions with secretaries to line ministries, heads of departments and trade unionists to gather information for the review. Furthermore, the Committee undertook 18 individual case studies with the help of the SLIDA to obtain empirical data on some aspects of public administration such as review of field staffing and financial management. Thus, the Committee ensured the effective participation and consultation with all stakeholders within and outside the public service.

The Committee functioned from July 1986 to December 1987 and made a number of recommendations to solve the problems identified by the Committee. It submitted its findings to the President on $31^{\text {st }}$ December 1987 in ten separate reports, each dealing with a specific issue or a group of issues. Subsequently, they were published on the orders of the government.

In carrying out its task, the Committee analysed the problems in the public service in depth and aimed at fair and sound judgments which displayed a practical awareness of many difficulties encountered in the public service. The Chair of the Committee, H.S. Wanasinghe, in an interview recalled his experience, after 20 years, on how they constructed the problems which they recommended for fixing, why and how they took the approach they did,

Basically as a group we met. Each of us started thinking about the problems in the public service at that time, wrote down, discussed them, analysed them and finally came to conclusions. We looked at the issues to be addressed and causes of such deficiencies in delivering services. We made separate reports on the assumption that it would facilitate a more comprehensive treatment of the different issues and also a more effective implementation of its recommendations. It also enabled the committee to submit its recommendations expeditiously on issues in its TOR which had assumed special urgency. We saw the committee's recommendations as an integrated agenda of reforms. We expected to implement the agenda as a whole by the proposed ministry of public services. We thought doing A without doing B or C would be counterproductive (Interview, 09.11.2007). 
However, the Committee recommendations were not fully implemented by the government of the day, but in a piecemeal manner despite the Committee's plea to implement them as a whole.

In an attempt to discover future prospects for public sector reforms in SL, the ARC review provides a solid base and a starting point. Therefore, this chapter examines the background of the ARC and key areas of study, problems identified, key assumptions and recommendations in order to highlight its historical significance in administrative reform initiatives in SL. The principal aim of this analysis is to show that most of problems they identified still exist in the public administration arena after a lapse of 20 years with new issues as explained in Chapter 4 due to nonimplementation of most of its recommendations. Therefore, any future attempt must be based on the lessons learned from this.

\subsection{Why ARC and How it Came into Being?}

This question was answered by the Chair of the ARC, H.S. Wanasinghe, in an interview;

Basically the productivity has been dropping. Overstaffing was recognised. The public service has gone without any direction. Quite a bit of achcharu (like a pickle). The Finance Minister, De Mel, himself was a Civil Servant and worried about what was happening in the public service.

He went on to say,

The 1977 economic reforms surfaced the inefficiency of the public service. In that the public sector has to help the private sector led economy. However, the public administration did not go along with the economic reforms. Completely it was a new world. The public sector applied rules but not act as a facilitator to the private sector. So the World Bank triggered the reform. The reform idea came from the World Bank through B. Mahadeva who was the Director General in the Finance Ministry and Lloyd Fernando, the Director General National Planning. There was also a report by the SLIDA. Director SLIDA also wanted to do some reforms. In addition, there was an administrative devolution underway. So, B. Mahadeva, Lloyd Fernando, V.T. Navarathna and also Thilakarathne of the Central Bank were the architects of the ARC. They prepared the TOR for the Committee along with the World Bank and pushed it through the Finance Minister, De Mel, to get the sanction from the President (Interview, 09.11.2007).

Accordingly, the ARC was a product of many people. Initially the SLIDA had recommended establishing an $\mathrm{ARC}$ by the President at its colloquium on 
administrative reforms in 1983 (SLIDA, 1983). The World Bank also emphasised the same need in 1986 (Fernando, 2005). So, "it was the IMF/WB, from their comparative experience saw the malaise and applied heavy pressure" (Marga Institute, 1995, p. 1).

The move for ARC was neither politically nor public driven. "The public did not perceive administrative reforms as affecting their daily lives or future well being - to them 'the government' was something esoteric which did not concern them. Thus, there was no 'public pressure group' for administrative reform" (Marga Institute, 1995, p. 1). Neither the Cabinet nor the Minister of Public Administration were involved in the decision to establish the ARC, or knew the work of ARC. Even the President did not think that it was important to notify and consult the Cabinet (Marga Institute, 1995), so the ARC came into being due to the external pressure backed by some of the reforming bureaucrats.

As mentioned by the ARC Chair, the SLPS has gone without any direction, leading to a drop in productivity. This was due to various factors as already discussed in the previous chapters: the increasing role of state control on public administration and economic activities, introduction of political leadership to the district administration, abolition of the independent PSC and the complete transfer of its functions to Cabinet. Appointments, promotions, transfers, dismissal and disciplinary control of the public service and their policies were determined according to the whims and fancies of the politicians in power. This led to politicisation of the public service, bureaucratic lethargy, inefficiency and lack of morale. The effects of these policies could be seen from the fact that growth declined from 5.3\% during the period 1966 1970 to $2.9 \%$ during 1970 - 1977 (Wijesinghe, 1998). This decline led to unemployment, shortage of essential food items and other materials, and unrest in the country which eventually led to the change of the government at the general election in July 1977.

The change of government from the SLFP shifted the way of thinking on economic policies. The incoming UNP Government opened the economy and introduced outward-looking development strategies in 1977 by deregulating many aspects of the economy. This was partly driven by global pressures. During the first four years 
since the opening of the economy the highest average growth of $6.5 \%$ was achieved (Wijesinghe, 1998). Along with the economic development, SL underwent considerable structural transformation in the economy, polity and society during the period from 1977 to 1994 . The dependence on the agricultural sector decreased and service and manufacturing sectors were boosted, thereby increasing employment opportunities and income.

However, there were some impeding factors because these economic reforms were not supported by administrative reforms for their smooth operation. With the market liberalisation, deregulation, corporatisation and privatisation, the role of the government should have been reduced to the role of a facilitator and a regulator, but it did not happen. Rigid public sector systems and procedures hindered the effective and efficient delivery of services to the investors as well as to the general public in the open economic scenario. In this background the public sector got caught in the cross-fire (Wijesinghe, 1998).

In addition, there had been pressing internal reasons for embarking upon a radical and comprehensive process of transformation and reforms. The youth insurrection during 1987 to 1989 in most parts of the country, and the demand of the Tamil rebels for greater devolution of political power in the North and East led for constitutional and structural changes. Accordingly, the government wanted to have an administrative system which would facilitate ethnic harmony and greater democracy to peripheral levels through devolution of power.

It was in this context in the latter part of the 1980s, the government constituted the ARC to support the economic reforms introduced in 1977 and the constitutional reform of devolution. Given the poor status of state administration, it was not surprising that there was an urgent need of reforms in the late 1980s for a much more efficient, effective and impartial public service, improving the quantity and quality of service provision, redressing imbalances of the past and addressing the demands of the minority population. The ARC was expected to carry out comprehensive investigations of the operation and development of the public services, and to make recommendations for improving and accelerating the reform process in line with the government vision. It was argued such a Committee would play a role in adding 
momentum to the economic transformation and devolution process. Therefore, the purpose of the ARC was to provide not a detailed plan but a broad policy framework to guide the public sector in introducing new policies and legislations aimed at public service transformation. The development of specific strategies would be the responsibility of the proposed Ministry of Public Services. The following section examines the key areas of study in detail and the key deficiencies identified in the ARC review.

\subsection{Key Areas, Findings and Recommendations}

The ARC was assigned seven priority areas for public service transformation in its Terms of Reference: public service cadres and salaries; management development; recruitment, promotion and transfers; decentralisation of administration; financial management; work systems and procedures; and distribution of subjects among ministries and departments. Accordingly, it was a broad review and evaluation of the whole system.

The ARC identified deficiencies in three key areas which obstructed the progress: the structure; personnel system; and work systems and procedures. Under the structural deficiencies the Committee identified the lack of "a system-wide focal point" to handle public service personnel functions and effective decentralisation, delegation and devolution of authority, and responsibility within the administrative system. It also observed the proliferation of departments, ministries, authorities and public enterprises over time, increasing the public sector involvement in economic activities.

The key deficiencies in the personnel system include: weak cadre management and compensation especially in senior management; absence of national training policy for the public service and the shortage of institutional infrastructure and resources for training; lack of mechanism to redress grievances of public servants; and the absence of an objectively selected multidisciplinary group of senior managers to provide managerial leadership. 
In regard to work systems and procedures the Committee found that they were ineffective, obsolete and client-unfriendly and the use of modern technology was inadequate.

In addition, the Committee observed high levels of overstaffing, low salaries, poor morale and discipline, erosion of standards of integrity, lack of training and selfimprovement, low productivity, high cost of government operations, and erosion of public confidence.

The ARC's recommendations for overcoming these problems, placing the administrative system on the right track and developing good governance in the government business in SL, are summarised below under eight main headings adopted in its report: cadres and salaries; senior management group in the public sector; personnel management processes; training and management development; rationalisation of functions; restructuring of administrative system; financial management; and non-departmental organisations. The recommendations of each category are discussed below.

\subsubsection{Cadres and Salaries ${ }^{58}$}

\subsubsection{Cadre Management}

The ARC argued that the number of cadres (406,359 in 1987 excluding armed forces) of the public service was beyond the reasonable requirement for efficient government operation. The ARC believed that there was no justification for the existing number, given the resources available and the priorities of government. The ARC further argued that the choice before the country was between a bloated, undercompensated and ineffective public service or a lean, better compensated and effective service.

The ARC observed several contributory factors for excess staffing: a lack of effective institutional machinery and a well-defined process for cadre determination; lack of staffing norms and standards and modern office equipment; and increasing

\footnotetext{
${ }^{58}$ ARC Report No 2 of 1986, pp.1-27
} 
number of ministries, departments, and public enterprises. The ARC observed under-utilisation of staff and narrow job definitions at subordinate levels as common practices in the government offices. In addition, "the existence of more than one ministry which either covers a single sector (e.g. agriculture) or seeks to further a single development objective (e.g rural development) has led to overlapping and duplication of field staff at field level who perform tasks which are indistinguishable from one another". Furthermore, the ARC found that the quality of staff in the public service was poor. This was mainly related to the "defective recruitment processes" and "lack of induction training."

The ARC recognised that systematic cadre management was the immediate task of the government to realise administrative reform and performance improvement. It recommended:

Establishing an independent Cadre Review Commission (CRC) immediately to evaluate structures, and to examine the existing cadres of all ministries and departments in the light of their current mandates. The CRC should be a permanent feature in the administrative system to carry out reviews on regular and continuing basis;

Right-sizing the cadres in the public sector. The ARC recommended the retrenchment of cadres in a phase-out manner and consideration of alternative service delivery mechanisms such as outsourcing;

Effective freezing of all recruitments for two years pending the completion of the first round of the review and rationalisation of cadres;

Introducing a scientific manpower planning process in the public sector accompanied by rigorous organisational reviews, modernisation of work systems and methods, continuing training, and retooling of existing cadres to cope effectively with new as well as different tasks of the future, and termination of tasks which were no longer relevant as well as the divestment of functions which could be better absorbed by community organisations and the private sector; and

Paying fair and equitable compensation to those who were to be retrenched. 
Among these recommendations only the first, the setting up of the CRC, was implemented but it disappeared soon after so these problems continued. The other recommendations, right-sizing cadres, and introducing manpower planning did not eventuate. The recommendations concerning the salary structure are as follows.

\subsubsection{Salary Structure}

The ARC strongly believed that the salaries of the public service were not sufficient in relation to the cost of living. This was crucial in the managerial and specialised skills levels, when compared with the national and international comparable salary structures. For example, the SL annual salary level ranged from SLRs 13,248 to 99,648 in 1987. Although, India's per capita GNP was lower than SL's, a public servant's salary ranged equivalent to SLRs 19,800 to 237,600 per annum. In Malaysia the range was from SLRs equivalent of 34,200 to 762,000 per annum. The ARC recognised high level of overstaffing and low salary structure as the 'twin malady' which afflicted the administrative system of SL.

The ARC's recommendation on salary structure was strongly based on the following assumptions:

The need for the government as both the country's largest employer and the one engaged in the key tasks of nation building, to be in the position of being able to attract and retain qualified personnel to handle given tasks at given level of responsibility;

The importance for the government as a 'good employer' to ensure that it has a contented workforce by seeing to it that the physiological and psychological needs of its employees are reasonably met.

The Committee believed that efficiency in the public administration depended on the integrity and commitment of the individual staff. The Committee was also of the view that the lack of association with the living standard expectations of the public servants detracted from such efficiency, integrity and commitment, leaving whole systems ineffective.

Accordingly, the ARC recommended: 
Increasing public servants' salaries;

Linking the salary structure to country's cost of living index;

Implementation of a uniform salary structure for the whole public service. The Committee assumed that this would attract equal calibre personnel to all jobs in the public service;

Assignments of salaries to specific posts based on a process of job classification. The salaries should be linked to the job content and the responsibilities of the specific posts; and

Reduction of number of salary scales.

The first recommendation was immediately implemented without following the logical sequence i.e. review of cadres, retrenchment of excess cadres, and then increasing salaries to the right sized cadres. Instead, the government increased the salaries of the bloated cadres. The recommendation of linking the salary to cost of living index was implemented in 2006, but the rest of the recommendations are yet to be implemented.

\subsubsection{Senior Management Group (SMG) ${ }^{59}$}

The ARC viewed the public service as a systemic whole. Though different tasks of the government were performed by different occupational groups, they comprised an integrated, single service which served a common vision, mission and objectives. It was different from any other service due to its uniqueness in delivering public services.

With this perception, the ARC observed that there was no planned or selected multidisciplinary leader group at the top to fill the most responsible positions such as Secretaries to Ministries and Heads of Departments to generate a cohesive and coordinated policy management in the public administration. Instead, those positions

${ }^{59}$ ARC Report No 3 of 1987, pp.1-15 
were filled by 'a collection of individuals' selected according to patronage, thus lacking group spirit, leading to an ineffective administrative system.

Therefore, it strongly recommended establishing a multidisciplinary, 'leader group', small in number, at the top, to fill the most senior positions in the public sector. The Committee expected that this group would provide the public service with qualitative leadership, and would function as the interface between the public service as a whole, and the legislature and the political executives. The Committee had given special attention to this proposal.

\subsubsection{The Personnel System ${ }^{60}$}

The ARC argued that the personnel system is central to the effectiveness of the country's administrative system because it was the focal instrument for formulation and implementation of development plans and policies giving leadership and management to government business. It provided managerial, analytical, professional, technical and scientific support for carrying out the process of SL's development forward.

In this context, the ARC observed several weaknesses in the personnel administrative system in the country: no cohesive public personnel policy; no institution to handle policy matters on personnel management and administrative reforms; no proper standards for recruitment; no promotions in the public service without political patronage and decision-making; and no effective performance appraisal system in the public service. Secondly, the committee found the personnel system over the years had failed to recruit and retain better qualified personnel. Thirdly, there was a high level of transfer of personnel from place to place, annually creating problems for the individual staff, family and the organisations.

The ARC observed that as a result of these weaknesses, the public service had lost its vitality, credibility, and productivity. It witnessed an erosion of morale, lack of motivation and increased injustice in the public service. The ARC assumed that

${ }^{60}$ ARC Report No.4 of 1987, pp. 1-39 
better qualified candidates would have tended to be discouraged with the common perception of subjective and unprofessional personal management systems and the prevalence of political decision-making in the public service.

Hence, the ARC arrived at two important recommendations: (1) establishing a Ministry of Public Services under the President as a focal point to handle policy functions on personnel management and administrative reforms with five directorates. Since the establishment of such a ministry might take time, the committee recommended that an effective secretariat under its purview with suitable senior staff to be introduced; (2) re-establishing an independent Public Service Commission (PSC) to perform public sector recruitment, promotion, transfers, and disciplinary functions.

The ARC assumed that the introduction of the independent PSC would have several advantages: restore morale; enhance the sense of security among public servants; facilitate adoption of more integrated approach on personnel matters; enable Cabinet to devote more of their scarce time for policy formulation and review; and assist in re-creating an integrated, neutral public service free of divisions based on political considerations and loyalty. The first recommendation has never been executed. After many years, the second recommendation was partially implemented in 2001 as described in Chapters 4 and 5.

In addition to these main recommendations on the personnel system of the public service, the ARC made several other recommendations on various aspects such as recruitment, promotions, transfers, retirement, manpower planning, grievance procedure, performance appraisal, which are highlighted below.

\subsubsection{Recommendations on Recruitment}

Abolition of existing Job Bank scheme of recruitment through MPs for non-staff (non-managerial) grades;

Introduction of open, competitive and merit basis recruitment procedure;

Decentralisation of all recruitments to non-staff grades enabling recruitment by specific institutions or provincial services; 
Formulation of job descriptions and schemes of recruitment for each post; and

Stop appointments outside the schemes of recruitment.

The first and second recommendations were partially implemented by the government in late 1989. The lower grade employees (peons and drivers etc) are exempt from merit-based recruitment. The third and fifth recommendations were not fully implemented. The fourth recommendation was introduced, but many organisations did not adhere to this policy.

\subsubsection{Recommendations on Promotions}

Typically the years of service (seniority) was the main criteria adopted in deciding promotions in the SLPS. The ARC regarded promotion as 'an exercise in talent hunting'. It viewed that an individual has to be measured against future demands with present and past performance. The ARC, therefore, recommended that promotions be based on such appraisal exercises which are designed to test candidates against the requirements of the new post to be filled.

Today, Efficiency Bar examinations are held to promote staff from lower salary points to higher salary points. Obtaining postgraduate qualifications is a requirement for promotions in some of the AIS, for example SLAS. However, promotions to the most important posts are still done on an ad hoc basis as discussed in Chapter 4.

\subsubsection{Recommendations on Performance Appraisal}

The ARC observed that performance appraisal in the public service since Independence was confined to an annual confidential reporting system, which led to subjective judgments, personal bias, favouritism, and an outdated value system. This system was seen as a control mechanism and did not support career management or the formulation of training needs. Annual salary increments were automatic, not performance-based. 
The absence of a proper performance evaluation system in the SLPS and the lack of integration with other human resource management functions such as considering promotions, granting salary increments and assessing training needs, had contributed to lowering performance standards, reducing morale and increasing frustration in the public service. In this context public servants had sought other ways of support to gain promotion and career advancement despite the ethical values of the public service. This meant that public servants at the junior or middle level sought personal favours from the politicians and higher echelon bureaucrats to gain promotions, while the higher echelon officials built up the practice of doing favours for the ministers.

In this background, the ARC recommended introducing an objective, regular and continuous performance appraisal system to evaluate quality, quantity and style of performance of individuals in the SLPS and linking the appraisal to other aspects of personal management such as promotions, granting salary increments and training.

In 1998, this recommendation was implemented, but there are still weaknesses in the process as discussed in Chapter 4.

\subsubsection{Recommendations on Transfers}

The ARC observed that there was a high volume of annual and ad hoc transfers in the SLPS: "Generally around $25 \%$ of the public servants spend the second half of each year preoccupied with impending transfers and finding ways to avoid transfers which could be to their personal disadvantage" (Report No. 4, p 29). Almost all the public servants attached to transferable services suffered from this dilemma.

The ARC stressed that the disadvantages of transferability outweighed the advantages. Disadvantages included additional cost to the government, and psychological cost to the individual staff and family. The transfers badly affected children's education. The transfers also led to lack of commitment to institutions due to 'temporary attachments', and ineffective implementation of development programmes of the government. It also negatively affected accountability. However, 
the ARC was of the view that there might be instances where transfers were needed for the sake of both the public service and the individual staff.

In this scenario, the ARC was of the view that, if the second recommendation under the recruitment section above i.e. future recruitment should be institution based and province based, is implemented, this problem could be overcome over the next few years. Pending the implementation of that recommendation the ARC made following interim recommendations:

Transfers between stations should be made only at the beginning of the year;

The employee should be given minimum three months notice; and

Transfers should never be used as a disciplinary measure.

Accordingly, the government outlined its transfer policy enabling an individual to be in one place over a period of five years. However, due to non-implementation of a decentralised recruitment system in the SLPS, the annual transfer problem still exists.

\subsubsection{Recommendations on Retirement}

The ARC observed that 55 years was the compulsory retirement age in the SLPS and extensions thereafter were annual and at the discretion of the government. The Committee noticed increased re-employment of such retirees in the SLPS without any rationale. It also observed that public servants did not have any right to retire before the age of 55 except on the grounds of bad health or a government retrenchment project.

The ARC noticed that these policies and practices had created several inter-related problems such as a sense of insecurity, lack of morale, and frustration in the SLPS, leading to low productivity. Thus, it recommended the following proposals.

The compulsory age of retirement of public officers should be set at 60 years with full pension; 
There should be no extension beyond that age. If it is essential, it should be done on a contract basis only for a one-year period. If it needed to be continued beyond that period, there should be a new appointment limited to another 12 months on the basis of performance, and there should be a condition of training of successors on such contracts. Salaries should be paid disregarding the pension, but such salaries would not be further pensionable.

Any public officer should have the right to exercise early retirement prior to $55^{\text {th }}$ birthday, having completed 20 years of service, and to draw a pension on the attainment of the age of 55; and

The pensions should be linked to the cost of living index enabling the pensioners to live simply with dignity.

The first and third recommendations were implemented. However, the most important second recommendation is yet to be implemented. Many senior level posts including Ministerial Secretaries and Heads of Departments are filled by retired personnel under patronage. This has been a common practice for a long time in the SLPS, demoralising subordinates and depriving them of promotions. In addition, Central Bank officials who retired under the special retrenchment scheme before the age of 55, with attractive compensation packages in 2000, have been recruited to various departments of the Ministry of Finance on a contract basis with higher salaries than the SLPS comparable posts, without any condition such as training of their successors.

\subsubsection{Recommendations on Grievance Procedure}

The ARC argued that 'justice and fair play' play a vital role for the credibility of the personnel system in the public service. The Committee assumed that, in a vast sector with a huge cadre and a multitude of decision-making points, there could be instances where unknowingly or even knowingly, wrong decisions or misjudgements could be made in recruitment, promotion, transfer, and disciplinary matters as well as any others. The ARC believed that the public servants affected by any wrong decision should have the right to appeal. It was observed that the personnel system lacked such an instrument. 
The ARC, therefore, recommended that, in such matters public servants should have a right to appeal to the proposed PSC or an appeal board constituted under it.

The government implemented the above recommendation by appointing an 'Ombudsman' in place of the PSC for this purpose.

In addition to these main areas of personnel system the ARC made several other recommendations such as provision of official transport to senior officials whose services were needed outside working hours, provision of soft loans for housing, and institution of a scheme of compensation to public officials who were exposed to high risks in their performance such as the armed forces, and other public servants working in risky areas. The ARC assumed that effective implementation of the above recommendations would enhance commitment to public duty, dedication to public interest and would retain public service vitality.

\subsubsection{Training and Career Development ${ }^{61}$}

The ARC outlined three major constraints relating to training of public servants: shortage of funds, inadequacy of trained trainers, and reluctance to release public servants to undergo training. The Committee stressed that these constraints arose due to absence of an authoritative National Training Policy. In addition, the ARC highlighted several weaknesses relating to training in the SLPS: the fractured, uncoordinated and ad hoc character of the arrangement; lack of integration of training with career development; irrelevant content and ineffective methodology of training programmes; lack of interrelationship between foreign training and local training; and an absence of training units in ministries and departments. The ARC particularly stressed many weaknesses in the foreign training: donor driven programmes which necessarily did not meet the SL requirements; lack of earnestness in the approach; lack of planning based on training needs of the SLPS; ad hoc selection; and non-adherence to the regulations stipulated in the Establishments Code.

${ }^{61}$ ARC Report No. 5, of 1988, pp. 1-29 
There was no planned programme of training at a pre-determined point in a public servant's career; rather it came about as a result of an individual's needs. As a result, there were several gaps in capability in the SLPS: limited capacity for planning and management of development programmes; inadequate technical skills; lack of supervisory skills; inadequate skills of policy analysis and management; inadequate awareness of the development environment; and lack of ethical norms and values.

The ARC stressed that effective mobilisation, development, and utilisation of personnel in the SLPS were important goals because they helped to build up both individual and organisational capacities and good governance, which were critical for the success of the country's development process. The ARC, therefore, made several recommendations to upgrade the quality of the public servants in general. They were:

Formulating a National Training Policy;

Strengthening the existing SLIDA for the training of management grades and establishing a Public Service Training Institute (PSTI) with decentralised centres for the training of supervisory and middle level grades;

Launching a priority programme of training for trainers through the SLIDA;

Releasing public servants full time to undergo postgraduate programmes, acquisition of postgraduate level qualifications prior to assumption of responsibilities at the deputy head of departmental level, acquisition of further higher level qualifications in public policy management and technical fields prior to assumption of responsibilities at the head of department level, and planning regular exposure to seminars, workshops;

Placing the National Institute of Business Management (NIBM) under the proposed Ministry of Public Service to enhance its role and contribution to staff training of the public enterprises; and

Providing funds for training as a part of the emoluments of each ministry. 
In addition to these recommendations the ARC gave direction in preparing training contents and methodologies for each of the occupational groups in the public service, and drafted a National Public Service Policy Statement. The ARC emphasised the need for three institutions, SLIDA, NIBM and PSTI, in fulfilling their mandate to develop a network of training, constituting non-institutional programmes in addition to institutional programmes. Furthermore, it recommended several measures to enhance institutional infrastructure of SLIDA, PSTI, and training of trainers.

The first recommendation has never been implemented, the second recommendation was partly implemented while the recommendation on provision of funds for training was executed in an ad hoc manner. The fourth recommendation was partially implemented.

\subsubsection{Administrative Changes in Support of Devolution ${ }^{62}$}

The ARC recognised that since Independence the centralised polity tended to apply prescriptive solutions, which were already discussed in Chapter 5, to development problems, ignoring the real reasons affecting those problems which existed in different parts of the country. These solutions, for example, DPAs, DM, and DDC, in practice created other severe problems leading to disappointment and disaffection of citizens. Although, authority was decentralised under these schemes, power remained with the central government. In addition, the Committee observed that the maintenance of unitary structure in SL was a continuing threat to the government, owing to two recent developments: the ethnic conflict and the youth insurrection.

The ARC, therefore, argued that the devolution (transfer of powers from central government to local units) would enable public participation in the development process. The Committee identified that the proposed devolution structure would comprise three levels: the Centre, the Province, and the Pradeshiya Sabah (Division), with representative institutions: the Parliament, Provincial Councils, and Pradeshiya Sabhas respectively. Each level would have a political executive, namely, the

\footnotetext{
${ }^{62}$ The ARC Report No. 6 of 1988, pp.1-43
} 
Cabinet of Ministers at the Centre, the Board of Ministers at the Province, and the Executive Councils at the Pradeshiya Sabhas.

Accordingly, the Committee emphasised the varying of functions of these three levels. At the Centre, would be the macro-planning, formulation of national policies, setting of standards and evaluation of policies, plans and standards. At the province level, the emphasis would be placed on the formulation of operational policies, programmes and budgets, the provision of technical guidance to Pradeshiya Sabhas and monitoring and evaluation of programme implementation. At the Pradeshiya Sabha level, project implementation and service delivery would be emphasised.

The ARC made several recommendations in this context, as follows:

Allocate operational responsibilities to the provinces optimally;

Keep the size of the concurrent list ${ }^{63}$ to a minimum;

Demarcate functions clearly between the centre and the provinces. The level (whether centre, province, or pradeshiya sabha) to which a subject is assigned should carry out the total responsibility in implementing the task;

Establish a Finance Commission;

Allocate resources between the centre and the province based on the devolved revenue;

Avoid the use of financial relationships as a control mechanism;

Avoid holding of greater discretionary power in sharing resources by the centre;

Establish a Provincial Planning Council. It was recommended that each Pradeshiya Sabha should act as a Planning Council for the purpose of appraising the annual development plan and monitoring its projects. Special training in these areas for provincial and pradeshiya level cadres should be arranged;

\footnotetext{
${ }^{63}$ The subjects concurrently managed by the centre and the province.
} 
Organise the subjects and functions of the province under 7 groups: provincial administration and personnel; law and order; local government and rural institutions; finance, planning, employment, and labour; agriculture, fisheries, trade, tourism, industry; economic infrastructure (power, irrigation, construction, roads and transport); and education, youth affairs, culture, health and social services;

Establish four standing committees within each Pradeshiya Sabha: finance and administration; agriculture and fisheries; industrial and economic infrastructure; and health, education and social services. There should be a Chairman at each Pradeshiya Sabha who would preside over the Finance and Administration Committee and three Vice Chairmen who would preside over the others. The Chairman and three Vice Chairmen would form the Executive Committee of the Pradeshiya Sabha;

Organise the future SLPS in five categories of cadres: institution-specific, pradeshiya sabhas, provincial, central departmental and all-island services; and

Establish a management pool - Provincial Management Service with different subgroups in each province to minimise transfers; and establish Provincial Public Service Commissions to handle matters of provincial public servants.

Of these recommendations only the fourth, eighth and final recommendations were implemented by the government. The outcomes of the failures were already discussed in the Chapter 4. The significance of the ARC report was that in 1987 it had foreseen the present problems, and suggested useful opinions on demarcation of functions.

\subsubsection{Rationalisation of Functions in Government ${ }^{64}$}

The ARC viewed the government's performance as dependent on the efficiency and effectiveness of the discharge of its tasks and functions. This, again, depended on the logical organisation of functions, and responsibilities among the different ministries and departments within the machinery of the government.

\footnotetext{
${ }^{64}$ ARC Report No7, 1988, pp. 1-24.
} 
In this context, the ARC identified several weaknesses in the structure of the government owing to the increased number of ministries, departments, authorities, and enterprises in the public sector, which had a negative effect on the development and the delivery of services ${ }^{65}$. These weaknesses were: a high level of separation of related functions within sectors; grouping of unrelated functions within a single ministry; creation of parallel institutions to carry out functions already assigned to existing organisations; inadequate coordination of policy functions; and inadequate institutional mechanisms for monitoring and evaluation of functions at the centre. Thus, there were overlapping, duplication, and conflict in functions, overstaffing, and lack of a systematic grading of departments.

The ARC, therefore, considered that there was a need to draw up functions, and responsibilities of government logically within a framework of well defined principles: affordability, sectoral policy cohesiveness and co-ordination, and close supervision and monitoring of policy implementation.

In this backdrop the ARC considered that policy formulation should be separated from policy implementation, thus a ministry at the centre should focus more on policy analysis and policy articulation, monitoring and evaluation of policy implementation, and inter-sectoral co-ordination with peer ministries on matters of national policy. The departments should focus more on operational and implementation functions.

The ARC made the following recommendations within the above framework recognising the real world political priorities and imperatives:

Abolish Project Ministries and make provision to have Ministers of State under the respective Cabinet Ministers assigning sub-sectoral and programme specific responsibilities within a context of much reduced numbers of large ministries;

\footnotetext{
${ }^{65}$ In 1987 there were 43 cabinet ministries, 5 project ministers, 25 district ministers, 92 central and 48 regional departments, 127 PEs, 25 kachcheries (ARC, Report No. 7, p. 4).
} 
Reduce the number of central government ministries (from 43 to 16) and departments, in line with devolution; and expand the range of responsibilities to them;

Not to appoint senior public servants concurrently to positions in corporations;

Give autonomy to commercial corporations. The Treasury as the custodian of the public investment should monitor their performance;

Establish a National Planning Council and a Planning Commission in the public sector; and

Reorganise the Cabinet Office to become a 'think tank' with inter-disciplinary and multi-disciplinary experts. The Committee identified that the current functioning lacked the necessary analytical support for collegiate decision-making on the major issues.

The fifth recommendation was partially implemented. The other recommendations were never implemented.

\subsubsection{System Improvement ${ }^{66}$}

The Committee argued that no work system in the public sector could be considered to be permanent; each must be continuously subject to evaluation and modification. The Committee viewed that an optimal work system would be one which enabled the work to be done within the shortest possible time, at minimum cost, entailing optimal utilisation of resources and minimising public inconvenience.

The ARC observed several deficiencies due to lack of efforts in improving work systems since Independence: process-related, system improvement and management effectiveness. The process-related deficiencies included multi-steps and lengthy work processes, a demanding plethora of information from the public sometimes not relevant for the purpose, no standard time for each stage in the work system, and

${ }^{66}$ ARC Report No. 9 of 1987, pp. 1-13 
inadequate delegation of authority. The deficiencies which impeded systems improvement included the lack of management culture in monitoring service delivery mechanisms or project implementation, mystification of the public sector work system and procedures, and the absence of institutional mechanism for the public to seek corrective actions on bureaucratic failures. The deficiencies which affected management effectiveness included slow progress in the introduction of information technology in service delivery.

In addition the committee observed that highly skilled personnel were employed in lower skilled tasks, and lack of attention was paid in 'system planning ${ }^{67}$. There was extensive use of letters and written memoranda as means of communications rather than face to face dialogue and telephone conversations in dealing with problems. As such, the work systems absorbed high personnel inputs, imposed unnecessary delays and burdens on the citizenry, and resulted in sub-optimal utilisation of human and financial resources.

The ARC recommended several corrective actions as follows:

Review and improve work processes in each organisation by each manager in relation to her/his responsibility;

Delegate responsibility and authority to lower levels;

Improve the office layout to enhance job supervision;

Enhance the use of computer technology and management information systems;

Establish effective mechanism to address public grievances; and

Devise appropriate work systems and procedures when new services are launched and when training cadres.

\footnotetext{
${ }^{67}$ When the new services established, adequate attention was not paid to the planning of work systems and procedures.
} 
These recommendations were implemented by several ministries and departments in various periods on an ad hoc basis, but there has been no cohesive programme of action across the public sector.

\subsubsection{Financial Management ${ }^{68}$}

The ARC observed that as a developing country with a scarcity of public finance, SL gave little attention to improving the financial management system despite frequent comments and suggestions for corrective action by the Auditor General. The ARC also noted that there were several 'Funds' ${ }^{69}$ in the public sector without parliamentary accountability and decisions over their use.

The ARC further recognised several shortfalls in various aspects of the financial management system, especially in the budgetary process, revenue collection, internal systems and audit, and supplies management. The following section examines these areas in detail.

\section{The Budget}

The following deficiencies were identified in the budget process from the departmental level to final approval in Parliament:

"A conceptual and an attitudinal problem". The approach to budget formulation was historically based rather than future oriented management decision-making. The study undertaken on behalf of the Committee revealed that "estimates of recurrent expenditure for the on-coming year are normally prepared in the mid of the current year based on the actual expenditure of the immediately preceding year";

"Inadequate and lack of professionalism" in budgetary negotiations between departments, ministries and the Treasury;

${ }^{68}$ ARC Report No. 8 of 1988 , pp. 1-25

${ }^{69}$ Example, various Lotteries, Cess Fund, Consumer Protection Fund 
"Inadequate consultation" of the sectoral heads on preparation of the departmental budgets. It was observed that the preparation of the budget was confined to the finance division of each department;

"Inadequacies in the budget presentation." The objectives of the department or the programmes were shown in general descriptive terms without expected outputs. As such the resources sought under each programme or projects were not linked to the anticipated outputs in any direct manner in the budget presentation, and

"Inadequate in-depth analysis of the budget proposals" at the Committee Stage debates.

In order to overcome the above deficiencies the ARC made several recommendations:

Obtain inputs from all sectoral heads in the preparation of the budget for the organisation, and to conduct training programmes to change their attitudes;

Remove the historical approach process in the preparation of the budget and revise the presentation format. The output of each programme under the department should be clearly spelt out for the budget period and each output should be directly linked to the relevant objective in quantitative terms. Each resource input should be clearly linked to the relevant output in the programme;

Establish several 'Budget and Appropriation Committees' which would study the budget of each ministry in detail and report their findings and recommendations to the full House for formal approval. These committees would replace the existing "Committee stage debates." The ARC expected that public accountability would be better served through this reform.

In fact, although these recommendations would have been very useful for the effectiveness of the public finance management, unfortunately little action has been taken so far to implement them.

\section{Revenue Collection}

The ARC observed the following weaknesses in the area of revenue collection: 
Lack of attention to collecting and monitoring revenue by the revenue collection agencies;

Lengthiness in the process, and paying-in procedures;

Complicated forms filling exercise;

Lack of payment points in the country; and

Delays in the realisation of inward remittances in government departments.

The Committee particularly observed that recording inward remittances, depositing them in banks for collection, acknowledging these receipts to senders and crediting to the respective accounts, took noticeable delays. Similarly, there were also delays in sending out such receivables. The ARC viewed that these delays were due to poor organisation of work, absence of work output norms, and absence of monitoring.

Therefore, the ARC recommended:

Introducing monitoring of revenue collection against pre-set targets and institutionalising this practice in the administrative system by using modern information technology. The programmes could be arranged both in the Treasury and the revenue collection agencies and departments; and

Streamlining paying-in procedures, simplification of forms and documents, shortening of payment processes, and expanding the payment outlets by using the post offices and the banking system.

In fact, the revenue collection was the main task of administration under colonial rule. The implementation of those recommendations would have direct impact on their own: overcome the shortages of funds in the government, minimise the levels of external and internal debt, and reduce the budget deficit in the country. Nevertheless these recommendations were implemented in an ad hoc manner. The Financial 
Management Reform Project (2003-2007) has addressed some of the issues in Chapters 4 and 5.

\title{
Internal Financial Systems, Audit and Procurement Management
}

In addition to the above two key areas, the Committee observed several deficiencies in internal financial systems, auditing, and procurement management. The Committee viewed that frauds, negligence, wastage, under-utilisation of assets and process delays in the SLPS were signs of the deficiencies of the internal financial management systems.

\begin{abstract}
Audit
The ARC observed that the audit reviews were essential in financial management, in terms of control and public accountability. It recognised that the existing internal audit lacked comprehensiveness. The reviews were confined to checking the financial integrity of the transactions to see whether transactions were correct and all assets were accounted for. It had not focused on whether each operational centre in the departments had made use of human and other resources allocated efficiently and effectively, enabling the top management to evaluate each cost centre under its control and to take necessary corrective actions.
\end{abstract}

The ARC also observed late submission of annual accounts, and there was no penalty or disciplinary action for such delays. There were several other weaknesses: lack of comprehensiveness in the external audit, financial data, and information management system, in the SLPS. Therefore, the Committee recommended:

Establishing audit units in ministries at the centre and the provinces and in departments;

Introducing penalties for late submission of annual accounts;

Introducing a performance audit as a part of the annual audit process; 
Releasing the proceedings of the Public Accounts Committee to the public through media; and

Creating a financial data and information management system in the SLPS.

During the late 1990s the timely submission of annual accounts was emphasised but only a little improvement had been made. However, other recommendations are yet to be implemented.

\section{Procurement and Supplies Management}

The ARC observed that more than $50 \%$ of public expenditure was on supplies procurement. Therefore, special attention was paid to ensure that they were procured at the most economical price and good quality in relation to price, timeliness, openness, fairness and objectivity, and that assets were properly managed and maintained. The Committee recognised that none of the above criteria were met in current practice. Instead, there were unnecessary delays, avoidable variations to tender procedure and unnecessary tying up of funds in supplies obtained prematurely. The Committee also noticed that although there was a separate department for government supplies, its function was marginal and many of the procurements were carried out by individual departments and ministries on their own.

The ARC, therefore, recommended:

Introducing a team of trained professionals in procurement management under the Ministry of Finance;

Giving appropriate training to managers on domestic and international bidding and procurement;

Providing training for all categories of staff handling financial management functions; 
Specifying the authority, responsibilities, duties and rights to Accounting Officers and Chief Accounting Officers in assuming their duties and the penalties for failures to such responsibilities; and

Reviewing the financial management system periodically and make necessary changes periodically.

During the late 1990s the first and second recommendations were implemented. The Treasury prepared Guidelines and Tender procedures for public procurement, and conducted awareness seminars for senior public officials. In 2005, a separate agency called the National Procurement Agency was established by dismantling the Finance Ministry Unit on Procurement. In February, 2008 it was closed down and its functions were transferred back to the Finance Ministry.

\subsubsection{Public Enterprises ${ }^{70}$}

The ARC observed that successive governments in SL had established various forms of non-departmental organisations such as corporations, boards, authorities, councils, institutes, and agencies in the administrative system to accelerate economic, social and political development in an unplanned and inconsistent manner, without any rationale. The Committee did not see any real 'definitive differentiation' between these organisations. However, it recognised that these organisations emerged due to a specific public policy or strategy, for example, the State Plantation Corporation and the Janatha Estate Development Board, which emerged as part of the policy on nationalisation of plantations. They emerged to handle regulatory, sector specific or regional basis functions, infrastructural development, research, and economic activities.

During its review, the Committee identified several weaknesses in non-departmental organisations: lack of uniform national policy and evaluation of alternative institutional mechanisms in creating such organisations; operational autonomy; trained staff; parliamentary oversight on accountability; and lack of clarity in regard

\footnotetext{
70 The ARC Report No. 10 of 1988, pp. 1-27
} 
to relationships with other organisations such as the Treasury, line ministry, and national planning. In addition, there was political interference in the appointment of directors and senior managers, delays in project execution, weaknesses in deployment of personnel, and high costs of service delivery.

In order to avoid such weaknesses the ARC made the following recommendations:

Non-governmental organisations should not be used to implement regulatory functions;

They should be audited by the AG. The audit should include both finance and performance audit;

They should be accountable to Parliament through the Public Accounts Committee;

These organisations should be established in clear and time-bound terms. The 'Sunset ${ }^{\text {'11 }}$ principle should be strictly applied to these projects;

They should be established under a particular ministry and the interface with the Treasury should be through the line ministry;

There should be an operational management board at the top and a full-time executive head of the organisation. All members of the board should have at least 20 years of management experience in large organisations;

The Chairman of the Board should be appointed by the Cabinet upon the joint recommendation of the sector Ministry and the Treasury;

All investments in the commercial PEs should be approved by the Cabinet; and

A Public Investment Corporation should be established by Act of Parliament to handle matters relating to investment, appointment of board members, approval of plans, and auditors.

\footnotetext{
${ }^{71}$ The idea of self-retiring government programmes after completion of their mandates embodied in the concept of 'sunset' principle.
} 
The second, third and sixth recommendations were partially implemented. Appendix 8 summarises the key recommendations which were implemented and their status up to date, and Appendix 9 summarises the recommendations which were not implemented.

\subsection{Critique and Prospects}

Given the limited time frame and increased violence in all parts of SL during 1987, the breadth and depth of ARC findings, the quality of its analysis and rather robust nature of some of its recommendations are astonishing. It was the first serious attempt and the only comprehensive study undertaken since Independence in the context of SL's public sector reforms. In fact, it was a sophisticated reform programme for SL. Many of its findings, assumptions and recommendations are still valid as is evident in the discussion of the present situation of public administration in SL in Chapter 4. If effectively implemented, many of the ARC recommendations, particularly establishing an independent Cadre Review Committee, Public Service Commission, Ministry of Public Services, and introduction of scientific manpower planning systems and rationalisation of functions and responsibilities of ministries and departments should undoubtedly contribute towards an effective and efficient public service and could reduce the majority of the present problems.

However, unfortunately, the interest shown by the government in establishing the ARC appears to have evaporated when it came to the implementation of its recommendations. Although the recommendations were fully accepted by the government by Cabinet decision on February 15, 1990 (Somasundram, 1997) and by the SLPS, the ARC's pleas that "recommendations be considered in totality and implemented as a whole" and that non-implementation of its recommendations would be a "retrograde step in the administrative development of the country" were seriously ignored. Instead, their implementation took place in a piecemeal manner, thereby putting the administrative system back, rather than pushing it forward. The ARC Chair later critically commented,

There were no initiatives by the Government, the Parliament, the bureaucracy or public service trade unions for open discussions and acceptance, modifications or rejections of the whole agenda of actions proposed by the Committee. Instead, ad hoc measures were taken in response to specific pressures (Wanasinghe, 1994, p. 6). 
There is no major criticism that can be levelled at this report, except for a few omissions. The first omission is that given the large number of specific recommendations by the Committee, it would have been useful if the report had a summary of such recommendations in priority order and incorporated them into an implementation plan. The implementation plan could be phased according to a time frame. The second omission is that the Committee's findings and recommendations in regard to financial management devoted little attention to 'State Accounts' and 'State Assets' none at all to 'Debt Management', which are very important elements in the SL context. The third omission is that the report does not discuss the role of the Ministry of Public Administration that existed at the time, in the reform process. This represents an important omission.

Despite these shortcomings the ARC report represents an important milestone in the public sector policy deliberation in SL. This is mainly because the ARC drew lessons from SL's own mistakes in the past over ad hoc exposure to public sector reforms. In addition, it drew lessons from developing nations, such as India, Malaysia and Singapore and developed nations such as Australia and the United Kingdom, where appropriate in its analysis. In this manner the ARC was careful not to blindly adopt the sophisticated developed country models that evolved during that era. The Committee recognised the specificity of reforms in the SL context, so it made appropriate recommendations to correct such individual weaknesses in the administrative system in the hope of creating a solid base or preconditions for robust reforms in the future.

The next section examines why the ARC recommendations were not fully implemented by successive governments during the last 20 years under six major headings: lack of political will; resistance from bureaucrats/rigid and conservative bureaucrats; uncoordinated administrative power relations; lack of citizens' support or clear direction, prioritisation in the reporting methodology; power struggle by the Tamil minority and actions of Sinhalese JVP; and changes in polity and governments. 


\subsection{Why were ARC Recommendations not Fully Implemented?}

\subsubsection{Lack of Political Will}

The main reason for non-implementation of the ARC recommendations in their entirety was lack of political will. This was evident from the very first attempt at its implementation in November 1987. The Minister of Finance tabled the first two reports of the ARC along with the budget proposals for 1988 accepting the whole agenda but the government only accepted three of its key reform proposals for implementation: a new approach to salary revision, cadre management, and the introduction of a sunset clause to all programmes. As such, from the very beginning the integrated approach to implementation of ARC recommendations was undermined.

Although the government accepted these three proposals, they were not implemented effectively. In January 1988 after it had completed its review task, the ARC was transformed into the Salaries and Cadres Commission. However, in practice the Commission's role was confined to the review of salaries because in the SL context politicians need to please public servants who were underpaid; thus they tend to be more concerned about salary reforms rather than other type of reforms in the public service. H.S. Wanasinghe, the Chair of the Committee, emphasised the lack of political will in an interview,

President Jayewardene never believed in reforms. He took the report and thanked us. Nothing more than that. He needed more power. Executive power. Even President Premadasa did not want because it did not flow from his initiative. Some of the recommendations: devolution, restructuring the centre, senior management group did not appear to appeal to him. The whole episode of reform is giving up. Reduce the cadres; abolish something, independent commissions...so no one wants to lose. Every party needed to win in the next election. No one needs CRC [Cadre Review Committee]. They recruit people for totally unproductive areas. If you implement SMG, the politicians cannot appoint people they want as Secretaries. Therefore, they resisted the implementation (Interview, 22.12.2007).

The majority of the interviewees in this study confirmed that there has been no political will for public administrative reforms in SL. Lloyd Fernando, former State 
Secretary, Ministry of Policy Planning and Implementation (1989-1993), in an interview further added,

The politicians by nature are myopic. They have a short term horizon determined by the next election they have to face. Hence, they [politicians] have to deal with issues that could see and give them credit. Politicians who run the government are aware of the need for public service reforms. But, they always think that such reform could be postponed. As a result public sector reform takes a low position in their scheme of priorities. They also feel that such reforms could disrupt the status quo resulting in loss of personal control over administrators (Interview, 06.01.2008).

This lack of political will impacts on the whole administrative system and will be further displayed throughout the following discussion where appropriate.

\subsubsection{Resistance from Bureaucrats/Rigid and Conservative Bureaucrats}

The second major reason for not fully implementing the ARC recommendations has been lack of bureaucratic support. There seem to be few reforming bureaucrats in the SLPS. This was evident at the second attempt to implement its recommendations comprehensively. In the absence of creating a separate ministry as proposed by the ARC, the then Ministry of Public Administration, Provincial Councils and Home Affairs submitted a Cabinet Memorandum in October 1989, seeking approval to reorganise the Ministry and increase staffing to manage the implementation of reforms. In March 1990, after five months, the Cabinet approved the proposal and referred the request for additional staff to the Committee of Secretaries (Nadarajah, 1997). The ARC recommended introducing five directorates at the level of Additional Secretary but the Committee of Secretaries approved only one. Thus, a policy unit established in the Ministry of Public Administration for the implementation of ARC reforms did not get the required qualified staff. As such from the very beginning, there was a critical mismatch in the management of the integrated implementation of the ARC recommendations (Wanasinghe, 1994).

Again in January 1991, the said ministry submitted a Cabinet memorandum to implement the recommendation of establishing a Senior Management Group (SMG) with some modifications to the form envisaged by the ARC. The Cabinet referred this proposal to the Committee of Secretaries, but, according to the ARC Chair, "the 
proposal did not find favour with them" (Wanasinghe, 1994, p. 10). The Committee "rejected the proposal fearing that they may not be selected to it" (Somasundram, 1997, p. 349). They did not want to lose their positions.

Another reason might be that they did not like the suggested entry requirements or to undergo the induction procedure to enter into the SMG in addition to their years of seniority at that point of time because "ARC did not envisage automatic membership of such a group by virtue of a position in the administrative hierarchy. It envisaged a process of talent hunting. The members were expected to display capacity for policy management, crisis anticipation, and control, as well as leadership capability" (Fernando, 2005, p.124). It seems that the senior bureaucrats themselves resisted this reform because they were reluctant to introduce competitiveness to enter the SMG and for posts inside the SMG. They preferred seniority which was the easiest way to get into the highest positions under patronage. However, that system did not necessarily permit the most qualified personnel to handle particular tasks.

In 1996 and in 2003 again, there were further attempts at creating a SMG but without success. These attempts were influenced by some senior bureaucrats who were disappointed with the existing system and had necessary qualifications to be entered into SMG, and/or who had genuine desire to implement the new system for the betterment of the SLPS. Strong resistance by the rigid and conservative senior bureaucrats prevented all attempts at implementation.

Another example of bureaucratic resistance was evident in 1990 when "the Ministry of Finance and Planning, without consulting the Ministry of Public Administration or obtaining approval of government invited a UNDP mission to review similar areas as already covered by the ARC" (Nadarajah, 1997, pp.260-261). This action undermined the ARC and the attempt taken by the Ministry of Public Administration to implement its recommendations. The details of this project have already been discussed in Chapter 5. Thus; it was evident that there has been a lack of political and bureaucratic will to implement the whole agenda of the ARC's recommendations. 


\subsubsection{Uncoordinated Administrative Power Relations}

In addition to the lack of political will and bureaucratic support, uncoordinated administrative power relations that existed in the administrative structure might have largely hindered the smooth implementation of the ARC recommendations. The SL post-Independence administrative structure was largely based on the changes that followed the Donoughmore reforms of 1942 as depicted in Figure 8.

\section{Figure 8: The Post-Independence Administrative Structure of SL}

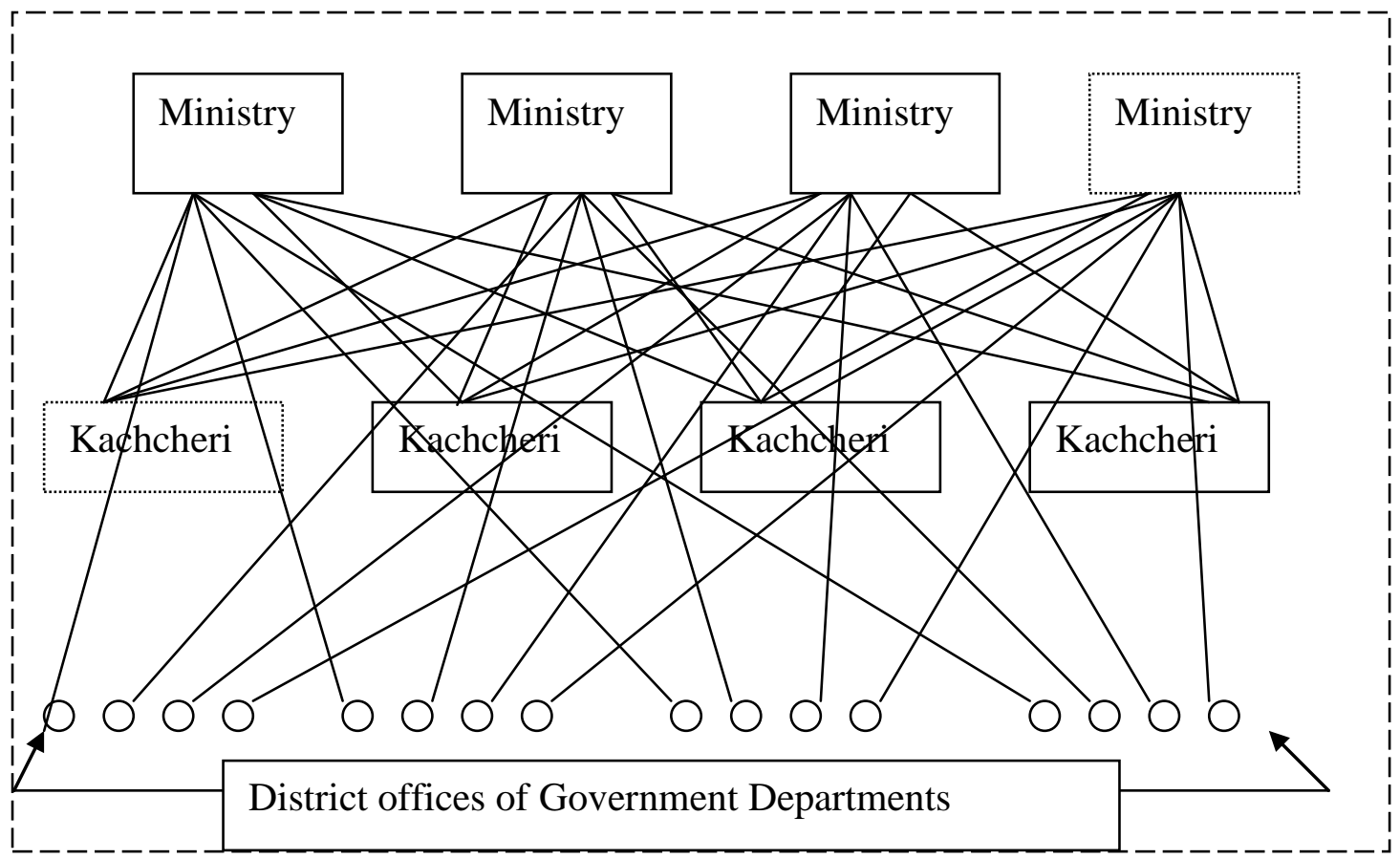

Source: Wijeweera, 1988, p. 11

According to this structure there were several ministries at the top with equal status and there was no single body to coordinate all functions at the top. The power relations and the chain of command of individual ministries were such that it flowed from the ministry to the departmental head office (located in Colombo which is not depicted in Figure 8), from there to the departmental branch office of the district and backwards, even ignoring the Kachcheri which was the coordinating body at the district. Therefore it lacked coherence and created confusion at the district level. Each ministry concentrated on its specialised functions, ignoring cohesiveness in administration. This network of administration was further complicated later in 1987 
with the introduction of the PCs in each province as the second layer of administration which was not displayed in the diagram.

As such the above structure was not conducive to the implementation of the full ARC recommendations, without establishing a separate ministry or a Secretariat at the apex under the President as a coordinating body as proposed by the ARC.

\subsubsection{Lack of Citizens' Support or Clear Direction, Prioritisation in the Reporting Methodology}

In addition to uncoordinated administrative power relations, there are other reasons for not implementing fully ARC recommendations. The first reason was the lack of citizens' support. The second reason was the reporting methodology adopted by the ARC itself.

In an interview, the Chair of the ARC, H. S. Wanasinghe, commented on the lack of public awareness, and the weaknesses in reporting methodology,

The people didn't know about the ARC. They did not know whether this was important. There was no real attempt by the media to give it [ARC's recommendations] to the public. Media will report on murders not on these matters. There were no well informed civil society groups which were active. Unless there is a tremendous public outcry there won't be any reforms.

He further said,

The presentation of the recommendations in ten reports defeated its very objectives that had in mind. It contributed to and encouraged a piecemeal approach to implementation; it facilitated a tendency to ignore the more difficult changes; it made ultimately the fizzling out of the reform process itself. Not being presented in a single document to which the public had easy access, the reform agenda also failed to mobilise the level of public interest and support which could have countered the implementation inertia (Interview, 22.12.2007).

Ten reports were published separately at different times, for example, Reports No.1, 2 and 3 were published in December 1987, Report No.4 in September 1987, and Reports No. 5, 6 and 7 in February 1988. Not publishing these reports as one document might have adversely effected the implementation of the full ARC recommendations. 
Furthermore, the ARC reports contained no phased implementation plan, no summary of the recommendations which could be easily understood, and no priority order for the implementations of its recommendations. The Chair of the ARC commented,

Our view was they [recommendations] should be addressed as a group. The prioritising of one area would not serve the purpose. We saw it as agenda of reform. It should be an integrated agenda. We expected the proposed Ministry of Public Service to plan the implementation strategy. They could decide what to do first or to modify. It did not happen (Interview, 22.12.2007).

This lack of clear direction on the part of the recommendations meant that other actors set their own priorities; for example, there was pressure from the Indian Government to implement devolution, and donor pressures for the implementation of their specific reforms such as deregulation and privatisation. This also might have contributed to the lack of attention for ARC. Furthermore, there was a lack of institutional capacity to implement them as a whole.

\subsubsection{Power Struggles by Tamil Minority and Activities of JVP}

Another major cause which distorted the implementation of the ARC reforms specifically and other social and economic development programmes in general, has been the power struggle by the minority Tamils and the actions of the JVP. The ARC released its findings at a turbulent and inopportune time. The years 1988 and $1989^{72}$ were politically chaotic ones with the LTTE activities on the one hand and the JVP uprising on the other, together with the high cost of living and confusion about the future of the newly established PCs which have been already discussed (Fernando, 2005). The Members of PCs were threatened by the JVP, some were shot dead (Shastri, 1992).

As explained in Chapter 5 the government brought the Indian Peace Keeping Force (IPKF) to the North and East part of SL to implement the Indo-Sri Lanka Accord in relation to devolution of power. The LTTE in the North was strongly against having

\footnotetext{
${ }^{72}$ Whilst LTTE activities spreading throughout the country during this period the JVP, Marxist party, fought against the establishment of PCs under the Indo-Lanka Accord. Thousands of youth died. The JVP organized several strikes in work places, and disrupted public transportation.
} 
the IPKF in their territory and increased their violence accordingly. In addition to the LTTE conflict, during the same period the Government faced severe threats from the People's Liberation Front known as JVP, in the South and other parts of the country. The JVP was vehemently against the Indo-Lanka Accord and the intervention of India in domestic conflict resolution. This was the second youth insurrection in the SL post-Independence history (the first insurrection occurred in 1971 due to the high level of unemployment and the policy of patronage recruitment in the SLPS). In this insurrection a number of successful strikes were organised in every sphere: government workers including nurses, bank employees, doctors, and estate workers. These incidents diverted the government's attention from implementation of the ARC's recommendations.

The ARC's Chair, H.S. Wanasinghe, drew attention to the remark attributed to President J.R. Jayewardene when asked why he did not comprehensively implement the ARC's recommendations,

I am fighting the LTTE in the North and the JVP in the South. Do you think I want to have a fight with the public servants in addition? - J.R. Jayewardene

Against this backdrop the government was swift to give salary increases to public servants; one of the ARC's recommendations, but ignored the logical order stipulated by the ARC: comprehensive cadre review, along with a detailed analysis of jobs in each public organisation, and failed to identify excess cadres and retrench them. Instead salary increases were implemented in the already-bloated bureaucracy. The pressure from the trade unions, the PC elections and the Presidential election scheduled for 1988 and 1989 respectively influenced the implementation of this recommendation. In its report the ARC had stipulated an indicative figure of $20 \%$ reduction of 72,000 cadres by mid 1989. This recommendation was not implemented until 1989. The failure to implement this recommendation led to dissatisfaction on the part of the donors who supported the structural adjustment programme at that time (Fernando, 2005). As a result, the Ministry of Public Administration offered a blanket retirement option to all public officers without pre-determination of specific 
categories of actual excess cadres by the circular 44/90 73 . Accordingly, public officials who were not in surplus and could get employment elsewhere got the opportunity of windfall retirement terms offered while staff actually in surplus remained in the SLPS. According to Fernando (2005), some of them were later reemployed. These actions in fact diluted the objective of reform.

However, the government failed to implement the critical recommendations made by the ARC in relation to devolution, ${ }^{74}$ which was aimed at resolving the LTTE conflict, except for the recommendation on a number of provincial ministries. S. Ranugge, the Secretary of the Ministry of Export Development and International Trade, in an interview said,

ARC's recommendations were very comprehensive, well prepared and documented, and superb. With regard to devolution they recommended to have 5 ministries at the provincial level. Otherwise we will have more ministries at the provincial level like in the centre (Interview, 19.11. 2007).

This failure to implement other critical recommendations on devolution together with other reasons led to the collapse the North and East PC, leading to disorder in administration as explained in Chapter 4. It also led to the downgrading of the process of administrative improvement. "Sri Lanka has paid a heavy price in terms of slow growth, missed opportunities, inadequacy of sustainability in the change introduced in the economy, the society and the polity and avoidable budget deficit" (Wanasinghe, 1994, p. 4). In addition, SL has lost many lives, properties and infrastructure facilities. The conflict also created psychological disorders in people.

Over the past 30 years until $18^{\text {th }}$ May 2009 violence has continued aggressively. LTTE have dominated in the North as a military group fighting with government, considering themselves as the sole representatives of the Tamil community. They did not allow democratic politics to play its legitimate role in the North and East and also

\footnotetext{
${ }^{73}$ Under this circular 30,855 personnel: 1123 in managerial grades, 9676 clerical grades, 8258 minor grades and 11,758 teachers were retired. The annual average retirement prior to this circular was 18,000 (Marga Institute, 1995).

${ }^{74}$ The ARC recommendations were: (i) keeping the size of the concurrent list to a minimum (subjects both centre and province concurrently exercise) (ii) making a clear cut demarcation of functions and development sectors between the centre and provinces; (iii) avoiding the use of financial relationships as a control mechanism; (iv) limiting the centre's discretionary power in sharing resources; (v) reducing the number of central government ministries and departments in line with devolution.
} 
did not allow maintaining law and order imposed by the central government in their area. The civil administration in the entire Northern Province has collapsed and the LTTE has established its own administration and judiciary. The LTTE terrorism spread to other parts of the country as well as to the world.

This situation led the successive governments to find a firm solution. It seemed that all governments tried to do something while still ignoring the ARC recommendations. The PA Government in 1995 presented a set of proposals including the creation of Regional Councils with more devolved power, and rectification of some of the shortcomings of the $13^{\text {th }}$ Amendment to the Constitution which established PCs (Somasundram, 1997). In 2002, the UNP Government proposed establishing an Interim Administrative Body. However, these proposals were unsuccessful due to lack of support from the other parties in Parliament. Thus, all successive governments throughout their times in office were preoccupied with finding a solution to ethnic conflict but ended up with military actions from both sides.

Accordingly, during the last two decades since the ARC completed its report in 1987 recommending a series of reforms with a view to establishing an efficient, effective, responsible and professional SLPS, the internal power struggle by the minority LTTE and the actions of the JVP group has diverted the government's attention towards military actions, hindering reforms recommended by the ARC.

\subsubsection{Changes in Polity, and Government}

Like the power struggles by various groups, the changes in polity and government might also affect the smooth implementation of the ARC's recommendations. This section examines these aspects in detail since the ARC completed its reports, from 1987 to 1994 under the UNP regime, from 1994 to 2001 and 2004-5 under the SLFP regime and 2001-2004 by the UNP. 


\section{During the Period of UNP (1977-94)}

The UNP Government which came to power in 1977 continued for 17 years, winning every election ${ }^{75}$ until 1994. It was the longest regime by one party since postIndependence. Therefore, one might argue that there was a stable government when ARC completed its report in 1988 and there was a possibility to implement its recommendations without any prejudice. Although the same party continued for 17 years, there were several remarkable changes in the UNP itself during 1987-1994. These changes badly affected the ARC reforms as well as the UNP itself.

Firstly, President Jayewardene, who established the ARC, completed his second term in 1989 amidst severe violence in the country. He appointed the Prime Minister, R. Premadasa, who opposed the Indo-Sri Lanka Accord to the UNP leadership. The Presidential election was held in 1988 amid unprecedented violence and a near total breakdown of law and order (Matthews, 1989), and Premadasa became the second Executive President in SL. Premadasa appointed D.B. Wijetunge as the Prime Minister and Minister of Finance by overlooking two prominent and intellectual senior ministers, one of whom deserved and expected to be the Prime Minister, namely Lalith Athulathmudali and Gamini Dissanayake. He offered relatively unimportant portfolios to these two charismatic ministers, mentioning that he would rotate the Prime Ministership on a yearly basis, but this did not occur.

Secondly, the new President inherited massive economic, political and military problems from the outgoing President. There were two major problems. One was the large number of Indian military forces (estimated around 100,000 as at 1988) in the country, who were brought especially to disarm the LTTE according to the Indo-Sri Lanka Accord (Matthews, 1989). The other was the JVP activities against the UNP regime as mentioned before. President Premadasa gave priority to solving these two problems. Once he solved them, by 1991 he went on his own agenda of reforms in decentralisation of administration by establishing 300 Divisional Secretariats at divisional level, giving more power by taking out the powers and functions hitherto

\footnotetext{
${ }^{75}$ SL parliamentary election is held in every five years. However, the election scheduled for 1982 was not held; instead a referendum was held to extend the period of the government for another five years.
} 
vested with the $25 \mathrm{GAs}$ at the district level (Chapter 3). He wanted to take the administration to the grass-root level which was a must for the day, and thus, he ignored the ARC.

Thirdly, in 1991, President Premadasa was accused by the other members of the party of having given arms and money to LTTE to fight against IPKF. He was to be impeached with 120 parliamentarians secretly signing the impeachment motion (Singer, 1991). The President, having got to know the secret, suspended Parliament for one month to find a solution to avoid being impeached.

In addition, he fired corrupt ministers and stopped the common practice of secretaries doing personal favours for the ministers for whom they worked. He became more and more authoritarian, and there was virtually no area that he did not involve himself in (Singer, 1991). Finally he defeated the impeachment and humiliated those who made the impeachment against him by giving them meaningless portfolios and depriving them of their power.

Fourthly, the impact of the above incidents weakened the UNP and the President. Some senior ministers including Athulathmudali and Dissanayake left the government and established another party in 1991. The President's party lost its majority so they had to look for the support of the minority Tamils or Muslims. These internal conflicts in the UNP might also have hindered the effective implementation of ARC reforms. As the ARC Chair mentioned, the ARC initiative did not flow from president Premadasa and he wanted to do things that he wanted, thus, no attempt was taken to implement its recommendations.

Lastly, in 1993, President Premadasa was assassinated by a suicide bomber while he was participating in a Labour Day rally and the Prime Minister, Wijetunge immediately was sworn in as the President following the constitutional procedures. Due to these changes in the UNP the PA (SLFP, Communist Party, Lanka Sama Samaja Party, DUNF) led by Chief Minister of Western PC, Chandrika Kumaratunga, was able to win the general election held in August 1994. 
Accordingly, the UNP that established the ARC lost momentum in implementing its recommendations in their entirety due to a number of clashes in its own party and its leadership.

\section{During SLFP Regime (1994-2001)}

The change of government from UNP to PA in 1994 distracted attention from the public sector reform initiatives of the previous regime. This period also saw a lot of violence in the country. The new government went along with its own agenda put forward at the election campaign: to eradicate corruption, make inquiries into human rights abuses, and find political solutions to ongoing ethnic conflict. Accordingly, the Bribery Act of 1954 was amended and a Bribery and Corruption Commission was established because the SLPS was highly criticised for alleged corruption. In addition, the Public Enterprises Reform Commission was established to streamline the privatisation programme of the government. Furthermore, the government appointed a Committee to Investigate Human Right violations by both previous UNP government and the LTTE (Somasundram, 1997).

President Kumaratunga also promised to abolish the Executive President system by changing the Constitution because there was agitation to remove it from the political system. The concentration of executive power in one person was thought to be harmful to democratic governance as President Jayewardene had obtained undated resignation letters from all MPs to control them, thus the implementation of ARC recommendations was given little attention.

However, later the President herself experienced difficulties in getting information from the ministries coming under her purview and witnessed that the SLPS was inefficient. ADB pressurised the President for administrative reforms (Wanasinghe, 2007), thus, she invited international consultants, from the United States and New Zealand, to the country in 1996 as mentioned before, drawing attention to reforming the SLPS but ignoring the ARC reports completed ten years earlier. However, according to the consultants, their recommendations were not implemented effectively by the government either (Root et al., 2001). 
Nevertheless, there were some reforming bureaucrats during this regime who were concerned about the ARC's recommendations. They introduced a PA system (Chapter 5) which was one of the ARC's recommendations through the Presidential Secretariat in 1998. However, the implementation of this reform to date has been inadequate and inefficient as mentioned in Chapter 4. The Chair of the ARC, H.S. Wanasinghe, commented on this attempt,

The potential of officials who pushed this reform agenda during the UNP and the SLFP regime are high, if they had the political will. There is a limit for what public official can do. No one could do anything due to lack of political will (Interview, 08.01.2008).

In addition to the change of leadership, a series of elections after 1994 might have affected the implementation of the ARC recommendations. Although the Presidential election was scheduled to be held in 2000, the President Kumaratunga advanced the election by one year. In addition, there were three PC elections in the same year. Furthermore in October, 2000, there was a parliamentary election so that the government was fully occupied with maintaining its power base, and had no time for anything else.

In 2000, the PA once again formed the government. During President Kumaratunga's second regime the only significant event occurring in the area of public sector reform was the creation of an independent PSC in 2001, which was one of the ARC recommendations, and which was achieved by amending the Constitution through the $17^{\text {th }}$ Amendment (Chapter 5).

However, this government did not last long. The Opposition, UNP, brought a noconfidence motion against the government. The economic difficulties, (the economy recorded negative growth rate $-1.5 \%$ ) and failures in peace efforts led to this situation. The President tried to protect her power inviting the Opposition to join with her creating a National Unity Government (Shastri, 2001). But the Opposition refused her invitation. The President suspended the Parliament on July 11, 2001 for two months to strengthen her position. She proposed to have a referendum for constitutional reform but without success. In the meantime some of her key ministers crossed over to UNP. Finally she dissolved Parliament in October 2001, calling for a fresh election. 


\section{During UNP Regime (2001-4)}

The UNP came into power in 2001 with a much reduced majority under the leadership of Ranil Wickramasinghe as the Prime Minister. The Memorandum of Understanding between the Government and the LTTE which led to ceasefire was reached. Due to cessation of hostilities the government was able to concentrate on economic and public sector reforms during its rule.

This government recognised the problem of overstaffing in the SLPS and banned public sector recruitment for two years, one of the ARC recommendations (Chapter 4). H.S. Wanasinghe, the Chair of the ARC, said,

The SL politicians think what is the use of being a politician if he cannot appoint persons to the public service, but Ranil [Prime Minister 2001-2004] personally might think otherwise, not others in his party. He realised that they are going to be bankrupted soon if the government recruits more people (Interview, 08.01.2008).

In addition, this government initiated new types of reforms according to the political and socio-economic condition of the country, for example, Financial Management Reforms (Chapter 5).

With the Presidency held by the SLFP and the Parliament by UNP, the government faced difficulties in approving policies. The Prime Minister faced problems over time. On November 4, 2003, the President took over the control of key ministries from UNP ministers and later suspended Parliament. She later dissolved Parliament calling for an election.

\section{During SLFP Regime (2004 一)}

This was the third election in four years. The UPFA (led by SLFP) won the election. The government was inactive until September 2004. The economy suffered once again during 2004 due to political instability and mismanagement of the economy (De Votta, 2004). In the same year some members of the LTTE departed and formed Tamil Elam People's Liberation Tigers. They started a hit-and-run attack on LTTE in the East (De Silva, 2005). In December 2004, the Tsunami killed thousands of people, rendered over a million of people homeless and damaged the whole 
economy. In the first few months of 2005, attention was concentrated on dealing with the post-Tsunami rehabilitation and welfare in the country. The JVP and UNP accused the government of using Tsunami foreign assistance to strengthen its political base (De Silva, 2005). As a result, in June 2005, the JVP crossed over to the Opposition in Parliament.

These illustrations from 1987 to 2005 show that the power hunger of SL politicians above national interest hindered meaningful advancement in the public sector, economy and the society. The enthusiasm shown by the UNP leaders in establishing the ARC diminished when it came to implementation of its recommendations amidst the political turmoil within the UNP itself. The craving of power by other political parties and the military groups and the violence throughout the country made the situation worse. Furthermore, a series of elections for Parliament, PCs, and the Presidency throughout this period, and Tsunami Disaster, distracted political attention and will in the implementation of ARC recommendations. Moreover, changes in the governments also badly affected the implementation of the ARC recommendations because the government of the day tried to implement their own agenda put forward by them in the election manifestos.

\subsection{Conclusion}

This chapter reviewed the ARC report of 1986/88 and examined why its recommendations were not fully implemented by successive governments since it completed its task.

The ARC in fact attempted to introduce an effective, efficient, politically neutral and citizen-oriented public service. However, this hope was eventually thwarted mainly due to the lack of political will despite its far-reaching recommendations. Moreover, a major puzzle remains as to why President Jayewardene ${ }^{76}$ established the ARC in the first place because it was evident that he did not seriously intend to do anything, despite pressures for reform by donors. Rigid and conservative bureaucrats further blocked the spirit of reforms. The reform agenda failed to mobilise the public interest

\footnotetext{
${ }^{76}$ President Jayewardene passed away in 1996.
} 
due to a lack of publicity. There was no effective citizens' group to make the public aware of the ARC recommendations and the need for getting them implemented. Moreover, there was no central agency to carry out the whole agenda of reform consistently as recommended by the ARC. The uncoordinated administrative structure was a great barrier for effective implementation of any programme. Furthermore, the power struggle by Tamil groups and the activities of the JVP political party along with the changes in the political environment and governments from 1987-2005, distorted continuous implementation of ARC reforms in their entirety. Therefore, it is pertinent to note that these barriers (except Tamils' violence at the time of writing) ${ }^{77}$ to reform still exist, thus should be taken in to account in the future reform exercise suggested in the next chapter.

It seems that there was no holistic effort to push the whole agenda forward, but in a piecemeal manner due to various pressures of the day. Many attempts were foiled and the majority of the reforms introduced were neither effective nor productive as expected by the ARC, for example, establishment of PA, and an independent PSC. Non-implementation of the whole agenda is evident and the consequences can be seen today (Chapter 4). If its recommendations had been fully implemented SL would have an effective, efficient, citizen centred and impartial public service today.

\footnotetext{
77 The LTTE was militarily defeated in May 2009.
} 


\section{Chapter 7: Study Findings and Future Prospects}

\subsection{Introduction}

This thesis is based on the assumption that a system of governance reflects the specifics of the country and any attempt at reform must be built on those specifics. The current status of government affairs and past reform experiences of SL, discussed in previous chapters (Chapters 4 and 5 respectively), demonstrate that the specifics of SL's political and administrative system have been a major impediment to reform.

This chapter discusses the suitability of the theoretical framework illustrated in Chapter 2 in explaining the reform experience in SL and revises that framework based on the SL's reform experiences. It also evaluates the success or failures of the reforms while assessing factors which assisted or may have impeded such outcomes. Further, it highlights major issues to be addressed, draws some lessons from past reforms and reaches some conclusions for future efforts.

\subsection{Applicability of the Pollitt and Bouckaert Analytical Model}

The Pollitt and Bouckaert model discussed in Chapter 2 brings historical institutional perspectives to change. It indicates broad forces which drive and resist change based on the study of 12 developed countries. According to this model decision makers are influenced by various elements such as socio-economic forces (global economic forces, socio-demographic changes, and socio-economic policies); political systems (new management ideas, pressure from citizens, and party political ideas); administrative systems (content of reform packages, implementation processes and results achieved); and chance events (scandals and disasters) in the reform process. This section discusses the applicability of these elements in the SL context and assesses the adequacy of the model in explaining the process of the SL reforms from 1950-2005. 


\section{A. Socio-Economic Forces}

Socio-economic forces including global economic forces, socio-demographic changes and socio-economic policies as shown by the Pollitt and Bouckaert, have had some impact on administrative reforms in SL. These elements have already been discussed in Chapter 5 and they are reiterated below in terms of their relevancy in SL's reforms initiatives.

\section{B. Global Economic Forces}

The influence of the donor community is a vital background factor for SL's reform. Multinational and bilateral donor agencies, especially the World Bank and IMF, have enforced privatisation, contracting out of public services, reduction of social welfare expenditure, and introduction of financial and civil service reforms. This was partly carried out under the Structural Adjustment Programme as part of conditional aid in the 1980s. It is evident that establishment of the ARC was influenced by the World Bank and IMF. Although the IMF office in SL was closed down in 2007 at the request of the JVP, it still continues to influence reforms through its reports.

\section{Socio-Demographic Change}

The other vital factor which influences administrative reforms in SL is sociodemographic change, for example, unemployment and ethnic disharmony have an important impact on administrative reforms. Unemployment created a situation of youth insurgency in 1971 and ethnic disharmony created a situation of war from 1983. The government established DDCs to create employment opportunities in 1971 and established PCs in 1988 in an attempt to solve the ethnic conflict.

\section{Socio-economic Policies}

The third background factor of considerable importance is the socio-economic policies of governments over time. The closed economy policy (1970-1977) led to a contraction of the economy whereas the government that came into power in 1977 
opened the economy. As a result, the country adopted policies of economic liberalisation and deregulation to attract foreign capital. It also adopted privatisation to promote efficiency and relieve pressure on public expenditure, and to bring about more market-oriented approaches such as contracting out public services and selling public assets to private parties. Further, it introduced the Janasaviya Programme (national poverty alleviation programme) in the late 1980s to reduce poverty (Wignaraja \& Sirivardana, 2004). The government that came into power in 2005 adopted the policy of non-privatisation.

\section{E. Political system}

Governments in SL change frequently and are often coalition governments. During these upheavals the position of the President (prior to 1972 a largely symbolic role) has become executive with more powers. The 1978 constitutional reform changed the electoral system from first-past-the-post to a Proportional Representation System with preferential votes. As a result, coalition governments have become the norm. Furthermore, there has been a move away from centralisation towards devolution with the major constitutional change in 1987 when provincial governments were introduced. Furthermore constitutional changes were introduced with the aim of depoliticisation of key institutions.

\section{F. New Management Ideas}

The New Public Management (NPM) ${ }^{78}$ ideas such as the US re-invention process, UK Next Steps, and the NZ and Australian versions of Contractualisation that had been circulating around the world during the 1980s with the aim of improving public sector efficiency and accountability reached SL in the 1990s. There was an attempt by the ADB (1996) to introduce some elements of the New Zealand reforms of the 1980s, such as the result-oriented management system and decoupling the policy and operational functions, but without success (Chapter 5). Nevertheless, it appears that

\footnotetext{
${ }^{78}$ NPM has become one of the dominant paradigms for public management across the world. The principles of NPM are characterised by an emphasis on output controls, disaggregation of traditional bureaucratic organisations and decentralisation of management authority, the introduction of market and quasy-market mechanisms, and customer-oriented services (Boston et al, 1991,Hood, 1990, p. 45)
} 
the recent reforms, the introduction of the Fiscal Management Responsibility Act (2003), establishment of the Management Assistant Service (2005), introduction of the Citizen-Client Charter (2006) and financial management reforms (2001-2007), are influenced by NPM ideas. In addition, the Productivity Secretariat of SL influences government institutions to adopt private sector practices and concepts such as the $5 \mathrm{~S}$ Concept, Six Sigma, TQM or ISO 9000 principles.

\section{G. Pressure from Citizens}

The Language Reform (1956) was influenced by the citizens, religious elites and party political ideas. However, in the current SL context pressure from citizens for administrative reform is very minimal as discussed in Chapter 6. This is mainly due to a lack of effective citizen's groups in SL although there are lot of political organisations. The media is now emerging but there is a lack of press freedom.

\section{H. Party Political Ideas}

The key group involved in the process of reforms in SL are political parties. Political parties continuously engage in the process of reforms, for example, electoral systems, education, health and decentralisation, because they need new policies and ideas to increase their political capital, appease party activists and advance their ideological beliefs in order to win elections. In the SL context party political ideas appear to have had much influence in the reform process. The nationalisation and establishment of PEs, the decentralisation efforts through the introduction of DDCs, DPAs and DCB by the SLFP, and the establishment of DM system, by the UNP governments are a few examples.

\section{Chance Events (e.g. scandals and disasters)}

The global economic crises as well as domestic scandals and crises directly impact on SL's reforms; for example, the global food crisis in the early 1970s influenced the UF government to establish the DPAs to drive food production locally. Furthermore, the majority of system improvements through information technology took place in the recent past because of fraudulent activities in the service delivery processes. For 
example, corrupt activities of issuance of passports, identity cards, drivers' licenses, and massive fraud in the IRD have led to several reforms.

\section{J. Elites in Decision-making}

The Pollitt and Bouckaert framework recognises that most of the changes in the SLPS originate from the top, particularly executive politicians and senior civil servants. The SL experience supports this theory. In most policy areas the main players involved in reforms are elected officials because they have the legitimate power to endorse and implement reforms during their administration. As noted in Chapter 5, decentralisation of administration through DDCs and the introduction of the Executive President came from President Jayewardene while introduction of DSs came from President Premadasa. During their regimes a privatisation policy was introduced in the early 1980s, although with only partial success and limited public support. Privatisation was subsequently banned by the present President Rajapaksa in order to keep the coalition partner, JVP, tied to the government.

Associated with the political elites senior bureaucrats are the second-most important figures in reforms. They are not only involved in policy development but also engaged in their implementation. They have legitimate authority through various enactments for improvement of productivity, efficiency and performance of institutions under their purview. They also enhance their own interests such as retaining their positions and perks, helping their family members and relatives to get into public institutions, and achieve promotions by strengthening their relationship with political masters. The introduction of DMs, the Citizens' Charter and Management Assistant Service were initiated by the senior bureaucrats.

In addition, the politicians and the bureaucrats are veto-players in the game of policy transfers, for example, the recommendations of the ARC were not fully implemented due to a lack of political will. Furthermore, the creation of a Senior Management Group and the strengthening of the policy unit of the Ministry of Public Administration to implement key recommendations of the ARC were obstructed by the senior bureaucrats. 
As noted in Chapter 5, in addition to the political elites and senior bureaucrats, the religious elites, trade unions, professional organisations, student front organisations, and political party supporters including businessmen are powerful veto-players in the public administrative reform process in SL. Influence of the religious elites was a critical factor in the Language Reform and sharing of power to the periphery. Many attempts at power sharing through the Bandaranaike-Chelvanayakam Pact in the late 1950s, and the Senanayake-Chelvanayakam Pact in the 1960s were foiled due to strong resistance by Buddhist monks. Similarly, trade unions are powerful institutions in the reform process. So far trade unions have contributed more in resisting reforms rather than supporting reforms, for example, they resisted the establishment of a Revenue Authority under the Fiscal Management Reform, and implementation of the ARC recommendation on reduction of public service cadres. Student Front Organisations resist the introduction of private higher educational institutions. The professional groups (Administrators, Lawyers, and Accountants) emerging in the $21^{\text {st }}$ century played a critical role in the introduction of the $17^{\text {th }}$ Amendment to the Constitution. In addition, the Head of State is also a key veto player in administrative reforms. The $17^{\text {th }}$ Amendment to the Constitution failed due to resistance from the President.

Accordingly, the SL elites primarily considered reforms which interested them, particularly focusing on the political feasibility of the reforms where they gain political capital rather than technical feasibility. One aspect however, in the SL context which is not covered by Pollitt and Bouckaert is pressure groups. This is depicted in the revised model introduced by this thesis at Figure 9 below (Box 1(v)). The pressure groups influence elites on their decisions on reforms as well as in the implementation process. Therefore, the proposition, "selection of reforms agendas by evaluating what is feasible out of what is desirable" noted by the Pollitt and Bouckaert model $(2004$, p.25) is not always in operation in every policy transfer in SL due to political considerations. As a result, some unfeasible reform agendas were hurriedly implemented by the political elites in order to harvest and retain power, knowing that they were unfeasible, for example, the Language Act.

In addition, according to the Pollitt and Bouckaert model, elites reassess reforms based on results. In the SL context elites reassess reforms not only based on the result 
but also reactions of other players (Figure 9, 1(v)). For example, after the enactment of Language Act in 1956, the government introduced the Language Special Provision Act in 1958 due to influence of the pressure groups and then later in 1987 made special provision in the Constitution giving equal respect to Sinhala and Tamil languages under the pressure of Indian Government (Figure 9, 2(i)).

\section{K. The Administrative System}

The Pollitt and Bouckaert model explains that administrative systems are often difficult to change in more than incremental ways because the culture and discipline are entrenched into the systems. This is evident in the SL context. The administrative system of SL is strongly aligned with the political system. From 1970s onwards, following the abolition of the independent PSC and assumption of its powers by Cabinet, and the abolition of permanent secretaries in 1972, patronage politics became progressively and more thoroughly embedded in the administrative system.

The reform in 2001 attempted to de-politicise several agencies, but expected outcomes are yet to be achieved due to reluctance of the political elites to depart from the vested interests, culture and discipline. Due to vested interests, this reform did not target total removal of political hands from personnel management functions. The attempt to introduce a performance-oriented culture also failed. The administrative system is more fragmented than before with so many ministries. Consensual and corporatist ways of doing things are very rare in the political administrative arena.

Reform from centralisation to decentralisation is somewhat difficult as discussed in Chapter 4 . The centralised polity and bureaucrats always resist devolving power to the periphery. Personnel management powers are decentralised but senior public servants in the provinces too are handpicked by the rulers. All the decentralisation efforts and other reforms through the ARC failed due to the unwillingness of these two groups to delegate their power. This shows clearly that administrative systems cannot change radically though they need such change due to the prevalent culture and discipline. 


\section{Content of the Reform Package}

The main factor in the Pollitt and Bouckaert model influencing content is elite decisions. As discussed, the SL administrative modernisation began in 1956 with the revolutionary change. When the Socialist Democrats (SLFP and its allied parties) returned to power in 1960 , they wanted to make the state machine more responsive and accessible to the ordinary people. The content of their reforms were based on that theme. They abolished elite services, the CCS and VH system, created the Ministry of Public Administration as a symbol of their reforming intent, abolished the PSC and took over its functions under the purview of the Cabinet in order to make public officials responsive to them. During the 1980s the right-wing UNP gave priority to decentralisation of authority to address the ethnic problem and focused more on economic reforms during its regime. Deregulation and privatisation were key contents. In the SL context reforms content essentially has been based on election pledges.

\section{The Implementation Process}

The most important part of the Pollitt and Bouckaert model is implementation of reforms (Figure 1, Box M) i.e. attempts to put reform ideas into practice, because the implementation of reforms through a top down approach involves a number of layers in decision-making and many levels of administration, from Cabinet level to the agency level. The chance of effective implementation of reform programmes therefore, depends on the willingness and incentive of politicians and senior civil servants to take decisions and implement reforms. In the SL context many attempts at public administration reforms have failed due to implementation inertia, for example, key recommendations of the ARC. Some of the recommendations were partially implemented while others were ignored. All the decentralisation attempts, DPAs, and DDCs suffered and PCs are suffering today due to the lack of willingness of the central ministers and bureaucrats to delegate adequate powers and functions to the sub-national level organisations introduced by the reforms. Therefore, as explained by the Pollitt and Bouckaert model the results achieved from the reforms were not always the anticipated outcomes of the 'reformers'. 


\section{N. Reforms Achieved}

There has been a lack of any systematic approach to evaluate the outcomes of reforms in SL so far. However, there was evidence to say that some of the reforms were partially successful but most of them were disappointing. Some were totally rejected by elites at the decision-making point while almost all had some type of problem at the implementation process. Therefore, almost all the reforms did not achieve intended objectives due to one reason or other. Reforms achieved will be further discussed in detail later in this chapter.

In summation, this section analysed the factors that contributed and impeded the postindependent public administrative reforms in SL by using the Pollitt and Bouckaert model and assessed its applicability in the SL context. This model provided meaningful guidance in explaining the reform experience but the model did not allow a full analysis of critical factors that contributed and resisted reforms in the SL context. Therefore, a revised model has been developed.

\subsection{Revision of Pollitt and Bouckaert Model of Public Management}

The Pollitt and Bouckaert model omits the role of politics and the power of major veto-players in the civil society such as religious elites, trade unions, professional groups, and political party supporters including businessmen, and the head of state, which could support or obstruct reforms in public administration. Similarly, this model does not explain the influence of "Administrative Reviews" and "Regional Power Groups' in elite decision-making. It explains only "New Management Ideas" and "Global Economic Forces" respectively. This may be mainly because the model was developed in the study's cohort of 12 developed countries. A revised model (based on SL experiences) for the purpose of explaining the reform experience in the developing country context is, therefore, developed and presented in Figure 9 below. 
Figure 9: The Revised Model of Public Management Reform

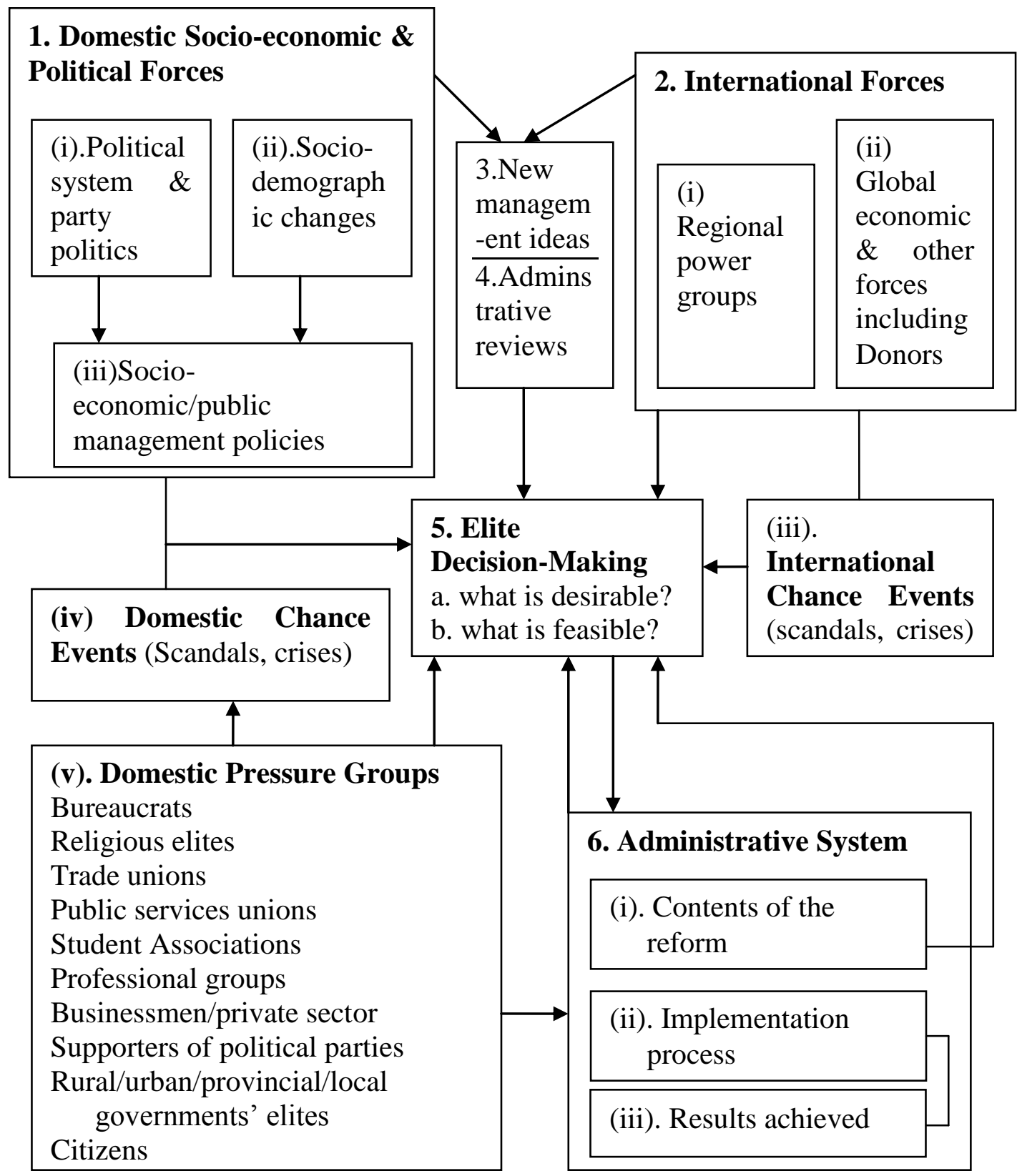

Figure 9 represents what has been learnt about the process of reforms in SL from the 1950s to 2005. This model depicts the broad forces, domestic and international forces and administrative systems that have been both driving and resisting reforms in SL. It shows the real complexity and the specificity of reforms process compared to the process in developed countries which was explained by Pollitt and Bouckaert. 
In short, at the centre of Figure 9 (Box 5) lies the process of elite decision-making. SL reforms were similar to the Pollitt and Bouckaert model in being predominantly 'top down' and conceived and executed by executive politicians and/or senior civil servants which enforced elitism. Surrounding the elite decision-making are four groups of elements. In the top left there is a group of domestic factors (Box 1i-v), political system and party political ideas, socio-demographic factors, socio-economic policies, chance events and pressure groups. Unlike the Pollitt and Bouckaert model this model recognises chance events, in a broader perspective, emerging from both domestic and international forces, especially from the pressure groups. In the top right there is a group of international factors (Box 2 i-iii), regional power groups, global economic and other forces including donors, and chance events. From the interplay of elements 1 and 2 there are two factors (Boxes 3 and 4, new management ideas and administrative reviews). From the interplay of these elements (Boxes 1, 2, 3 and 4) management reforms emerge. The bottom half of Figure 9, the administrative system (Box 6 i-iii), content of reforms, implementation process and results achieved is exactly similar to the Pollitt and Bouckaert model but there is a slight difference in the feedback loop where the elite not only reassess reforms based on results achieved but they are also influenced by the reactions of the pressure groups (1(v)). Then, they reformulate policies. The implementation process in the revised model is also influenced by the pressure groups. The interaction of those broad elements has already been explained in Section 7.2 above with practical examples from SL.

Accordingly, in this model there are two critical points for reforms to be introduced: Box 5 (Elites decision-making) and Box 6 (ii) (Implementation process). In point one (Box 5) the elites endorse reforms where they can gain political capital, or where coalitions support, if not they reject. In point two (Box 6 ii) even if the elites do accept reforms, they can still fail at the implementation stage due to influence of the pressure groups, for example, ARC recommendations failed due to resistance from bureaucrats and trade unions.

\subsection{Evaluation of the Reforms (1950-2005)}

The need for administrative reforms has been recognised by all successive governments of SL from time to time and several attempts have been launched, with 
mixed results. Major influences on reforms are socio-economic policies, the political disenchantment with the public service, the political desire to politicise public administration and later to de-politicise it by some sections of political elites, globalisation and decline of the economy, pressure on public resources caused by economic decline and demands of welfare state, internal conflict and scandals, and the influence of the new right ideals that favour a more market-oriented approach to public administration. As a result, SL adopted economic liberalisation, deregulation, privatisation, deconcentration and devolution of political and administrative authority, and re-organised the public service over time to be more aligned with the political needs.

In general, all reforms so far have been ad hoc and piecemeal. They have not emerged out of a meaningful, well-planned programme of public administrative reform followed in a phased manner but instead have been influenced by the political priorities of the day. There was no holistic, systematic approach to reform, although the ARC recommended doing so. The evidence obtained suggests that decisions were taken on a case-by-case basis in order to address the perceived problems at that time. Thus, all reforms have been implemented in isolation, reactive to crisis situations rather than proactive, which displays the pragmatic approach to problem-solving by all successive SL governments since Independence (1948).

As a result, the reforms so far undertaken have not delivered any positive outputs or outcomes but have had largely negative results. They have had adverse impacts such as over-politicisation (e.g. abolition of the PSC, introduction of DPA/DM); duplication of functions (e.g. introduction of Provincial Councils); over institutionalisation (e.g. introduction of branch offices); and waste, corruption and abuse of power (e.g. nationalisation, introduction of PEs and privatisation). Due to some reforms (e.g. language reform and abolition of CCS) the SLPS lost many of its best men. None of the reforms were intended or led to attracting quality people to public service. Missed opportunities were more than those seized. It is evident that some of these reforms were misguided by the political elites due to political desire to win elections (e.g. the Language Act), take revenge on the Opposition party supporters (e.g. abolition of $\mathrm{VH}$ ), extend the political power base and administrative 
decision-making (e.g. DCB), and safeguard their long term political survival and retain power at the centre (e.g. PCs).

It is evident that all the reforms failed. There were several reasons for this. The main reason seems to be that there was a powerful opposition to reforms from a large number of forces. These forces have been illustrated in Figure 9 of the revised model. The other reason was that there was a lack of foresight and common sense. Further, there also had been weak planning and implementation, for example, the DPAs lost their momentum due to lack of delegation of powers by the central ministers. However, this lesson was not taken into account when designing other decentralisation efforts such as DMs, DDCs and PCs. These reforms faced, and the PCs are now facing, a similar chaotic situation because they have not been founded on a solid policy foundation or theoretical underpinnings as in New Zealand.

The other factor which contributes to the failure of reforms was that there were no stable reforms because governments often changed and changed all the former policies and reforms with them. Reform on top of reform has been the problem in SL after Independence. There has been an inconsistency of policies in the government and the provinces due to lack of national policies as discussed in Chapter 4 which prevent whole-of-government and collegial actions. Even within the government there is a lack of consistency. One minister comes and does exactly the opposite of the previous minister, for example, changing school text books and examinations.

Some of the reform initiatives seemed to have had the opposite of the intended effect, for example, introduction of DDCs. The DDCs were introduced to solve a political problem i.e. agitation of the Tamil minority for greater decentralisation. The DDCs took over the functions of elected village and urban councils, thus village level participation in decision-making was undermined. Later the government realised the mistake and introduced the 'Gramodaya Mandalayas' and 'Pradeshiya Mandalayas' to fill the gap by an amendment to the DDC Act, but they were neither elected nor effective bodies (Sirivardana, 2004). As such, on many occasions reforms were made without adequate examinations of their effects on the system as a whole (e.g. DPAs, DMs, DDCs, and Official Language reform). This resulted in more problems or even greater complexity. 
However, some of the reforms were able to solve some of the problems; for example, public sector salaries have been raised on the recommendation of the ARC, and the language reform paved the way for the majority of people to interact with public administration. The creation of a unified CAS and abolition of $\mathrm{VH}$ achieved some of the objectives of the reform. The reforms helped to remove the 'caste system' entrenched in these two systems. The introduction of the unified CAS opened the door for educated rural young people to get into higher positions in the public service including women who had previously been overlooked. The decentralisation effort through DPAs, DMs, DDCs, and PCs gave recognition to the sub-national level. Accordingly, these reforms have had some positive effects but they produced largely negative outcomes because they were not properly designed and implemented.

On the other hand, other reforms failed due to conflict within the interest groups in administration. They have tried to promote their own interest rather than the country's interest. Accordingly, in the process of solving problems these reforms created another set of problems. For example, language reform had more far-reaching adverse, social, political and economic effects than any positive effects to the country as a whole. The primary consequence of this reform was the further division of the two major ethnic groups of the country, the Sinhalese and the Tamils, and the increased ethnic disharmony leading to a civil war. Although this is not the only root cause for ethnic conflict, according to the sources and many of the respondents in this study, language reform triggered the conflict. SL has suffered from 52 years of conflict, lost thousands of lives, missed many opportunities of economic and social progress, and spent huge sums of money (SLRs 102 billion only for 2007) (Ministry of Finance and Planning, 2007, p.89). The conflict caused by this reform has created a situation of unrest throughout the country and displaced thousands of people many times. Furthermore, the deterioration of ethnic disharmony and intensity of conflict also led to Indian intervention in domestic matters, leading to the signing of the IndoSri Lanka Accord in 1987.

Further, due to language reform, the number of Tamils and Sinhalese who possessed fluency in English with which they could converse with each other got sharply reduced, and this decline in fluency in the common language of English became a 
national issue by the 1990s. It created a monolingual society. Further, young people have been deprived of access to the wealth of knowledge and skills available to them and employment abroad. Many of the respondents remarked that in the 1960s and 70s many Sri Lankans held top positions in international organisations such as the World Bank, IMF and UNESCO, but today the situation is the opposite due to lack of English proficiency. One of the reasons for the high level of unemployment in SL is also attributed to the lack of knowledge in English in the educated youth due to this catastrophic reform. Therefore, the government has tried to accommodate educated youngsters in the public service, for example, the recent appointment of graduates to the bloated public service, in large numbers.

The political dimension in public administration is another key area in the SL context. The public sector is a sub-system of the political system. Thus, one cannot function effectively independent from the other. They are interdependent. Therefore, public sector reform will not be successful in the SL context without reforms to the political system. Almost all respondents of this study mentioned that public sector reform cannot be independent from political reform in key issues. In this context the challenge was that what sort of political reforms are feasible? The key areas that need attention in the political system which have direct bearing on public administration are: powers of Executive President (Chapter 3); checks and balances by the Legislature over the functions of the executive; patronage; and leadership (Chapter 4).

In summary, this section critically evaluated the result achieved from the postIndependent public administrative reforms (1950-2005) in SL. It highlighted why reforms failed, what factors contributed for such failures and the overall outcomes of the reforms.

\subsection{Major Issues to be Addressed}

Chapters 4 and 5 of this thesis raised numerous empirical and normative issues political and administration by nature such as: the plethora of public institutions; lack of clarity in government functions; bureaucratic overstaffing; lack of professional in the public service; informal appointments; corruption; duplication of government 
functions; lack of transparency, accountability, checks and balances or good governance; greater executive power over legislature; lack of political will to reform, the use of official language and political patronage in the public service. They directly or indirectly have negative effects on the socio-economic progress and well-being of the citizens. Therefore, there is a need for an overhaul and systematic approach for reforms to the present public administrative system. This does not mean that all the reform programmes have to be implemented overnight. Given the relative significance of the issue, the reforms can be lined up for implementation in priority order or where possible implemented concurrently.

This section highlights major issues that needs immediate attention and describes their relative significance for future prospects in priority order.

\subsubsection{Political Issues}

In the SL context political dimensions were the major bottleneck for effective reforms in the past. The enormous power of Executive President, lack of checks and balances by the Legislature over the Executive and lack of will to reform the public sector by the political leaders, and political patronage in public services are key issues identified by this thesis. Those should be given first priority in reforms. Reforms in the political system provide a base for other reforms in the long run. In addition, without addressing political issues, it is difficult to imagine reforms being effective in other areas in the administrative system because political dimensions are the backbone of the administrative system.

\subsubsection{Executive Presidency System}

The Executive President of SL enjoys enormous powers. The President dominates all decisions including control of public finance and other constitutional matters. In 2001, the $17^{\text {th }}$ Amendment to the Constitution attempted to curtail the President's power on key appointments, but failed due to resistance from the President. Under the presidential system, the legislature has been undermined and there are no checks and balances of the President by the legislature. It was evident (Chapters 3, and 4) that on 
many occasions presidential powers had not been used for good governance but badly misused due to the immunity granted to the position by the Constitution.

The Opposition and media highly criticised the Executive over the violation of the constitutional provisions in relation to the public service. The $\mathrm{CC}$ is defunct due to the unwillingness of the President to appoint its members. The de-politicisation of key government institutions expected by reformers is yet to be realised for this reason. The concentration of enormous powers on the one hand creates a situation of undermining the collective activities of the legislature and the Cabinet. There have been many occasions where presidents acted as dictators. Under the executive presidential system there is a risk of undermining the democratic principles and good governance, therefore, it needs a modification. The unusual strength of the Executive President is one of the unique features of SL's administrative system when compared with other South Asian countries (where there are presidencies of more ceremonial than real substance) which have similar settings. The Executive Presidency is one of the causes of the failure of administrative reforms in SL. Therefore, reform to this system is a first priority of the day.

\subsubsection{Political patronage}

As discussed in the previous chapters, political patronage is embedded and encompasses all spheres in the public administrative system including public personnel management functions. Although political patronage in regard to personnel management of the national cadre, except secretaries of ministries and heads of departments, was restricted by the $17^{\text {th }}$ Amendment to the Constitution in 2001 by transferring the powers of Cabinet of Ministers to an independent PSC, the political elites refuse to comply with the change. It is evident that they still try to enjoy the autonomy envisaged by the 1972 Constitution though it is no longer in operation, and the Cabinet no longer has power other than formulation of policies in relation to the public service. The Cabinet manipulates the recruitment procedure by making temporary appointments in the public service on political patronage and later making them permanent without due consideration of necessary educational standards to handle positions. The appointments to the higher strata of public service are still under political hands under the present Constitution. Therefore, the lack of 
meritocracy in appointments and promotions procedures in the SLPS is a key issue to be addressed.

These issues need immediate attention because these practices could lead to eventual degradation of the SLPS and deterioration of the quality of outputs and outcomes of the government programmes. Further, this system hinders equal opportunities for different communities to access public employment, thus violating constitutional provisions. In addition, the SLPS could lose its credibility, and impartiality. Moreover, the right people may not be in the right places in the delivery of public goods and services and to assist effectively in the formulation of public policies in the interest of the country. Because of the appointment to higher positions are on patronage public officials tend to get favours from political and bureaucratic elites for their promotions, thus training and development have been given little attention by individuals and institutions. This could further exacerbate the quality of services. In addition, this system may prevent the attraction of the best candidates from the job market for public sector positions.

Therefore, these problems have to be tackled without delay in order to preserve the quality of the workforce and to enhance credibility, impartiality, and professional public service, attract the best people for public sector positions, and achieve organisational objectives and socio-economic development in the country. The minority could be better off and bitterness of the war could be sweetened if the patronage of personnel management practice is abolished.

Other issues in the public personnel management which need attention are the public services structure (with a plethora of combined services), lack of manpower planning, effective cadre review, discipline, human resource development especially in the senior strata, and effective individual performance management systems. Furthermore, the shortfalls in the $17^{\text {th }}$ Amendment to the Constitution and delays in functioning of NPSC, the entity responsible for civil service staffing, are other key issues that need immediate corrections.

These issues needs short-term solutions because the lack of manpower planning and continuous cadre review system in the public service created a situation of 
overstaffing, underemployment, imbalance in cadres, and under-compensation. Lack of discipline in the public service and the legislature led to corruption, malpractices, degradation the SLPS and loss of faith and trust by the public over the public service. The supply-driven training and the lack of a proper human resource development system in the SLPS led to lack of professionalism in the SLPS. It also led to a lack of professionals in specialised jobs, especially in the higher strata. The lack of a proper individual performance appraisal system has contributed to lowering performance standards, reducing morale, causing inefficiency in service delivery, delays, lethargy, corruption, and increasing frustration within the SLPS. There is no incentive to work harder because there is no difference between the high performers and low performers. The shortfalls in the $17^{\text {th }}$ Amendment to the Constitution which were discussed in Chapter 5 created a situation of the non-operation of the $\mathrm{CC}$, the agency entrusted with the approval of appointments to some positions and the nomination to the President on candidates for others including the commissioners of independent commissions. Due to this situation those agencies are run by the personnel appointed by the President. In addition, the functioning of the NPSC also needed especial attention because some respondents in this study highlighted that there are delays in approval of appointments and transfers by the NPSC, thus, public sector institutions fail to run public businesses effectively. It lacks powers in relation to key appointments in ministries and departments and has no power on the personnel management of PEs. These issues need systematic approaches for correction.

\subsubsection{Structural and Institutional Issues}

The administrative structure is a key instrument which formulates and implements policies, programmes and projects for the betterment of the citizens. Therefore, the administrative system could be logically arranged in order to encourage the smooth functioning of government business. However, there are several structural and institutional issues in the present administrative system which include (1) large number of ministries with confused responsibilities and functions, (2) a plethora of loss-making commercial PEs and non-commercial PEs with duplication of functions, (3) duplication of responsibilities and functions in central and provincial governments, (4) lack of clear roles and responsibilities of the state and provinces, and (5) lack of real devolution. These structural issues have led to several negative 
outcomes such as delays, confusion, high costs, wastage, corruption, and underutilisation of scarce resources. Further, they create institutional problems such as overstaffing, inadequate checks and balances, lack of capacity for coordination of public policy management and systems and procedures, lack of citizens' participation or private-public partnerships. These structural issues are interconnected and have to be addressed and treated as a package. Otherwise, reforms would be counterproductive.

The present size of the Cabinet, other ministerial portfolios and public sector cadres exceed the needs of the country, thus, their existence and cost effectiveness cannot be justified. The continuation of a large number of loss-making commercial PEs and non-commercial PEs in the administrative machinery needs immediate reform because they draw significant amounts of public money for their survival, and, thus, obstruct investments in other critical sectors. In addition, the confusion of the role of the state and provinces is evident in the failed programme of devolution and the shifting political attitudes on privatisation. Effective devolution could be helpful in the present day context to address the Tamil interests. Further, real devolution may enhance Tamils' participation in economic and social development which is long overdue. The wounds of the war could be healed through such an attempt. Moreover, it could lead to lasting peace and national integration in the country.

In addition, there is a low degree of public and private partnership in relation to provision of goods and services. Since the introduction of a market economy in the late 1970s, the private sector has played an important role in the provision of goods and services. However, there is no effective relationship between public and private sectors for a common goal, i.e. socio-economic development in the country. Rather the "public sector continued to look with suspicion at the private sector" (Wanasinghe, 2005, p. 16). These perceptions hinder effective private sector participation in development. Public-private partnership has been introduced in services like telecommunications, but the full potential of the private sector has not been harnessed so far.

Therefore, these structural and institutional issues could be the second priority area in any future agenda of reforms because once structural issues are resolved and the 
structure is logically organised in the short run, it would also resolve a number of other institutional and non-institutional issues such as overstaffing, and financial problems.

\subsubsection{Language Issues}

The implementation of a trilingual policy is complex and faces a number of problems as discussed in Chapter 4. The lack of Tamil language knowledge on the part of the majority of Sinhala public officials, especially those who work in the provision of basic services to different communities, is the main concern of the Tamils. As a result, they are deprived of access to public services in their own language. This is one of the root causes of the 30 years of war. The shortfalls in the following constitutional provisions and lack of proper implementation of the Language Act led to this situation.

Article 22 of the Constitution declares that Sinhala and Tamil are the Languages of Administration throughout the country. It further states that Sinhala should be the Language of Administration of all provinces except the North and East while Tamil is the Language of Administration in the North and East. According to this provision Tamils living in other provinces and Sinhalese living in the North and East are unable to transact business with the government institutions in their respective languages. Many Tamils living in Colombo and suburbs cannot get their work done in Tamil due to the dearth of Tamil translators and interpreters in government offices. According to the Official Language Commission (2005), only 8.3\% of public servants are Tamil speaking. The Official Language Department and the Official Language Commission (OLC) have been in the administrative machinery from the early 1990s, but there is no significant outcome to improve the knowledge of both languages in public officials despite many reports and recommendations. It is reported that the OLC lacks autonomy and powers to implement the policy effectively.

SL is a multicultural, multi-religious and multi-ethnic society. Therefore, SL needs to meet the needs of the pluralistic society in which the language is a key element. In order to sustain the recent war victory and promotion of social cohesion and longlasting peace, the service provision could be on both official languages with equal 
status. Therefore, a long term programme of action is essential in the future reform agenda in order to overcome the language problem which is a priority issue of the day.

\subsubsection{Corruption}

As discussed in chapter 4, there have been 'mega' frauds and corruption at the state level by the upper echelons of elected and appointed officials in the public service. Corruption is institutionalised in some public organisations. A top political leader and a higher echelon public official were fined by the Supreme Court in relation to corrupt activities in the recent past. It is reported that there are around 300 elected and top public officials in the investigation list of the Bribery and Corruption Commission. According to this Commission, there were many complaints on corrupt activities in the private sector too but there is no law to investigate corruption in the private sector. This evidence indicates that the problem of corruption has become worse. It seems that the existing anti-corruption measures have been ineffective and inadequate. Thus, corruption has become a 'wicked problem' in SL.

In a corrupt public service, citizens are not afforded their democratic right of equal access to public services. In addition, corruption causes a loss to government in terms of revenues, and tarnishes the image of public services. Further, corruption impedes economic development. Although no country has recorded total elimination of corruption SL should try to minimise the present level of corruption.

\subsubsection{Inadequacy of Transparency, Accountability, Integrity and Good Governance}

There is a lack of transparency, accountability and integrity in public administration and governance. Currently citizens do not have knowledge and information on how public goods and services are delivered, who is responsible for and accountable to each action, and how the MPs and officials run the government businesses, except from some controversial reports by the media. Even the citizens do not know the changes in service delivery mechanisms including changes in ministries and departments, since they are very often changed according to the volatility of the 
political environment. Citizens in SL still remain passive recipients of public goods and services. Their participation in governance is minimal due to the lack of transparency in the conduct of public business, on the one hand, and the lack of political and bureaucratic arrangements at the local community level to obtain citizens' input, on the other.

The Official Secret Act and the standing Orders of Parliament prevent disclosure of information and open deliberations of Committees in Parliament especially the COPA and COPE deliberations. The perception of citizens in regard to transparency and accountability of public governance and integrity of public officials is not positive. The availability of information in areas of public policy and their implementation, of the facilitation of economic activities, and the maintenance of law and order, are important factors that all stakeholders of public administration are concerned with. The recent Supreme Court intervention in administrative matters, the VAT scam in the Inland Revenue Department and the Supreme Court judgements on the three privatisation deals discussed in Chapter 4 clearly show that there is a lacuna in transparency, accountability, integrity and governance.

Improvement in transparency, accountability, integrity, and governance in the public administration, therefore, may create a positive image and enhance the credibility and trust in public business. There is a need to hold public officials accountable for their actions, which also helps to minimise corruption.

\subsubsection{Lack of Results-Oriented Management Culture \& Deficiencies in Public Financial Management}

The government of SL lacks a performance-oriented administrative and political culture both at macro and micro levels. The input-oriented budgetary system, large scale recruitments to public service, recruitment of unqualified personnel to run public offices, lack of a performance measurement system for Secretaries of Ministries, ineffective performance appraisal on other categories of officials and lack of performance-based promotional and human resource development systems, which have been discussed in Chapter 4, clearly show that there is a lack of attention to results-oriented management practices in the SLPS. The financial expenditure, high 
attendance in public offices, and employment data alone do not display the progress of public administration. The lack of a results-oriented management philosophy in public administration may lead to less contribution of the service sector to GDP and disregard the value for money concept, thus, this is a priority area to be addressed.

Associated with the lack of a result-oriented management culture are several deficiencies in the financial management system as discussed in Chapter 4. Lack of a budget committee in Parliament; non-implementation of recommendations of the parliamentary watchdog committees; no response to the AG's observations on irregularities by the executive; non-adherence to financial and administrative regulations are a few examples which lead to loss of billions of rupees to the Treasury.

\subsubsection{Lack of Policy Management, Competition Policy or Regulatory Regime}

The main weaknesses in the current policy management process are the ad hoc nature of the task, and a lack of human resources that are needed for effective policy management and policy formulation in the political and administrative systems. More importantly there is an inadequacy of analysing policy options before reaching final decisions. There is also a lack of consultation with main stakeholders. Each event of public policy formulation is not preceded by optimal interaction among relevant sectors. Instead, policy formulation takes place in isolation in each sector of the economy, which needs cohesive policies. In addition, there is a lack of competition policy and regulatory mechanism in the administrative system even 30 years after the opening of the economy in 1977.

The ad hoc nature of policy formulation, lack of cohesive policies, policy management and regulatory strategies in the public administration hinders effective implementation of government programmes, collegial and joined-up government actions because each level tries to act independently (centre, province and local level). This leads to further wastage of scarce resources, delays in government activities, clashes in various sectors in administration and finally creates problems for 
citizens. Overall, the lack of policy management and regulatory regimes impede the socio-economic development, and therefore, need attention in the short run.

\subsection{Lessons Learned from the Past}

The lessons learned through past reform experiences and the fact that the ARC recommendations were not fully implemented (Chapter 6) are of great value in designing and initiating future reforms.

First, no administrative reform initiative in SL would be successful unless there is a strong and consistent political will and commitment, including the commitment from all constituents of the political gamut, not confined to the ruling elites on the objectives and strategies of reform agenda. In the case of the $17^{\text {th }}$ Amendment to the Constitution in 2001 the political commitment was there, but it was lost when it came to implementation. As yet, there is no consistent political will and commitment in SL to ensure the success of reforms.

Second, and related to the first lesson, a reform agenda has not taken into account the vested interest of all the stakeholders in public administration. Four groups in particular could be identified in the SL context for resistance to reform in the past: the political groups, bureaucracy, trade unions and religious groups. Resistance of political groups extends across the board and it is embedded into the SL political culture. The senior bureaucrats view reforms as a threat to job security, erosion of power and authority that they have enjoyed over time. The trade unions in the public sector gained more power over time due to the increased number of members, with the large number of recruitments in the SLPS and their affiliation with political parties.

Third, there is no attempt as yet to raise awareness and discuss proposed reforms at the national level among key stakeholders, including the public, to ensure their effective implementation. Therefore, raising awareness and consensus on objectives and measures of reforms among political parties and other stakeholders by the reformers is a vital factor. 
Fourth, there was no systematic approach to public administration reform in SL with proper plans and infrastructure. The implementation of the reforms was weak. In most cases there were no monitoring, reviews or rectification of shortcomings.

Fifth is the question of policy complexity. This is in fact true in the case of ARC recommendations because the reform agenda was not designed for implementation over the short term and long run given the reality of the polity and the availability of infrastructure and the relative significance of the problems. The holistic approach to reform does not mean that all recommendations have to be implemented overnight.

Finally, no administrative reforms should be implemented in isolation without necessary reforms in the political system or Constitution given the realities of the SL polity because the administrative system of the country is a sub-system of the political system. However, this requirement cannot be applicable across the board, for example, some reforms such as improvement of systems and procedures, reducing cadres and number of ministries in public administration, can be implemented without major constitutional or political reforms but SL's political history proves that even for such minor reforms some constitutional change will be helpful. For example, the $13^{\text {th }}$ Amendment to the Constitution restricted the number of ministers in the PC whereas the number of ministers of the national government has no such restriction. Therefore, any overhaul of reforms in the administrative machinery needs legal and political reforms to support it.

\subsection{Challenges for Public Management}

The current situation of SL's public administration (Chapter 4) suggests major reforms in the political and administrative arenas in the country, without which an efficient, effective, and impartial public service cannot be developed. In addition, the recent war victory of the government over the LTTE (May 18, 2009) created an atmosphere to reform many aspects of government business in order to bring the Tamil community into the mainstream administration and to bring everlasting peace to the country.The participation of all political cohorts, public servants, private sector and communities in whole-of-government and collegial activities may be helpful to achieve peace, social integration, socio-economic development and increase the 
quality of life of all Sri Lankans. In this connection the centre and province have to realign with a new deal. In this attempt a series of challenges are there for public management which raises a number of questions.

What is the role of the state? How to define and demarcate it? This is important because the role of the public administration depends on the role of the government. Similarly, what is the role of the province, district, and local governments in economic development and service delivery and reconciliation? In addition, there is a need for clarity in the roles, rights, responsibilities, freedoms and accountabilities of the public officials in key positions in the public service.

What is the appropriate balance between centralisation and decentralisation of administrative and political authority? What are the criteria for true devolution?

What is the role of the public sector in the development of peace in the country? How to bring Tamils into mainstream administration and development? How to reconcile the grievances of minorities? What are the priorities?

Can public administrative reforms be independent from political reforms? What sort of political reforms are feasible? This is important because the administrative reform is a political exercise.

What kind of 'bargain' or deal should exist between top politicians and top civil servants? What do they expect from each other?

How to develop a loyal, efficient, impartial, and capable public service?

How secure are senior public service jobs? Can top public servants remain at their posts as different governments come and go? Can top posts of government be opened to competition from inside and outside the service or appointments be made on contract for a limited number of years? Can the 
appointees be employed on performance-related contracts so that they can survive changes of government if performance targets are reached? Who is going to set targets and assess their performance objectively?

How can corruption be minimised?

How to judge how much coordination and stakeholder consultation is adequate?

What does it mean by to refer to the notion of an "independent public service"? What are the implications? How can adequate political control of the bureaucracy be achieved? This matter has to be cleared in the minds of the political elites as well as in the bureaucrats because at present there is no clear understanding on this matter on both sides.

How can the lessons drawn from the past on administrative reforms be transformed into something useful?

Answers to these questions are not simple but complex and crucial. Many factors have already been identified in this thesis as impeding factors for reforms such as lack of political and bureaucratic will; resistance from trade unions, coalition partners and religious groups; lack of support from citizens' groups; and unstable government. However, that does not mean no reforms can be successfully implemented. Given the political will and commitment, any problems can be sorted out.

\subsection{Conclusion}

This thesis critically analysed the current situation and the past public administration reform experience of SL from 1950 to 2005 using the theoretical framework introduced by Pollitt and Bouckaert to examine reform experience of SL. Due to several omissions in that framework, an alternative conceptual framework was introduced on the basis of SL's reform experience. SL's experience in administrative reforms has been complex and conflict ridden. Various reforms introduced so far have not been targeted to address the inefficiency of the public service. Similarly, the 
decentralisation efforts have not been able to address the Tamils' interests. Almost all the reforms largely contributed to negative outcomes. It appeared that many reforms were unable to deliver positive outcomes due to political considerations in the design and implementation of reforms; instead they created many more complex problems. Change after change with each change of government and the leadership in an ad hoc way has been the rule since Independence. Thus, while other countries such as Singapore, Malaysia and Korea, which had the same per capita incomes as SL in the 1960s, are moving ahead, SL is going backward. Today, these countries have per capita incomes that are several times higher than SL's.

How and why SL has fallen into this situation? How and why are all of the factors like this? Finding a simple answer is not possible because it is more complex than meets the eye. The first and most obvious reason is the 30-year long war which has taken a heavy social and economic toll on the country's performance. The other reason may be the unusual strength of the Executive President. Why was the President able to claim all those powers which are quite problematic? Why was the Constitution revised in 1978 to give the President those powers? Why did parliamentarians and citizens not oppose this and allow it to happen? Above all, SL has a long history of being a democratic country. Why did that democracy not work to correct the leader who proposed the revision of the Constitution? Didn't the Parliamentary Select Committee on Constitutional Affairs or the civil society, intellectuals, religious elites, media and the Opposition foresee the future outcomes as they saw in other government proposals in the past, for example, when religious elite, intellectuals, civil society and the main Opposition, the UNP, opposed power sharing through Bandaranaike-Chelvanayakam Pact in 1950s or the main Opposition, the SLFP, and the same group were vehemently against the power sharing through Senanayake-Chelvanayakam Pact in the 1960s. Why did such a movement not emerge to oppose the introduction of Executive Presidency?

Similarly, why were the ARC's recommendations not implemented? There are many factors. The overarching set of reasons would be that ongoing reforms require stable, peaceful, year by year continuous governing system. That is the only way the reforms are properly developed and implemented, but this was not in the case in SL. Therefore, if one tries to build up a model or develop an explanation on why and how 
SL's situation is like that the answer would be complex. The first half of the answer would be self-serving political culture and the second half of the answer would be that public service is driven by political motivation rather than technical motivation. The high echelons of public servants are appointed and beholden to the politicians of the day. Therefore, the level of stability and continuous development of public services is technically impossible. Self-serving political culture and patronage are not confined to SL but they have serious implications on the country's public administration and reforms.

Therefore, without establishing an enabling political environment the necessary administrative reforms would be impossible. The creation of an enabling environment is a hard and challenging task. Both political and bureaucratic elites should be ready to dedicate and commit for a new era of change. Therefore, the pathway forward is not clear but the Sri Lankans are common sense people. They are always passionate and strong about their responsibility towards their next generation.

There are several ways to achieve the enabling environment and a stable government. The first approach would be to get the basics right. There is a view that countries should get the basics right before attempting more advanced reforms (ADB, 2003). In this respect non-compliance to rules and regulations and other deficiencies in the administrative apparatus highlighted annually by the AG, COPA and COPE and reactivating the key recommendations of the $\mathrm{ARC}$ which are relevant today and were not implemented hitherto could be addressed first. Once the basics are established, during the first three to five years the government could concentrate on establishing an enabling environment in the political and administrative arenas. This enabling environment could be established through five areas: addressing the root causes of the 30 years of internal conflict of the country; reforming the political system including the Executive Presidency; addressing the key issues in the current public administration mentioned above; enhancing the use of information technology in the service delivery; and establishment of professional public service. Addressing the genuine problems of the minority could be helpful to bring peace and harmony among a divers community. In this endeavour devolution of a substantial amount of power and functions to the sub-national level, which was one of the demands by the Tamils since Independence, is desired as a long-lasting political solution. 
Another approach could be establishing a group of reformers with authority who would work together to try and shape everything in the right direction because the present Administrative Reforms Council does not seem to fully involved because its members, including the Chair, are engaged in other priority jobs. It is essential to have a separate permanent group who could take an holistic approach to address the issues continuously. Otherwise, attempts would be counterproductive. All these approaches are immensely difficult and will take time. A huge amount of resources will be required.

In all these approaches towards resolving problems, the big challenge faced by SL is the ability to respond, which depends crucially on the ability to reform the polity, and build and sustain high quality institutions, both private and public. This raises the question of scale. Is SL too small to sustain credible, capable institutions in the public service? How does SL maintain the quality of private and public institutions in a world of increased complexity and globalisation? In what areas would SL effectively exercise sovereignty through jointly controlled institutions by Sinhala, Muslim, and Tamil leaders? Can Sinhala, and Tamil political leaders and interest groups completely forget and give up unpleasant memories of the past which were hitherto exercised by taking revenge from each other for narrow political gains and negotiate a fair deal for a common goal and interests of all communities in the country?

If the government could overcome the 30 years of terror, then reforms in the public administration should not be that impossible. 


\section{Chapter 8: Post-Script}

\subsection{Introduction}

This thesis has been focused on public sector reform in SL from the 1950s to 2005, in particular in relation to implementation of the recommendations of the ARC $1986 / 88$ - the one and only comprehensive study of the system of public administration in the country. As this thesis was being completed, it was becoming increasingly clear that two events in particular had a potential impact on the matters raised in this thesis and warranted a short postscript chapter. The first of these events was the election of President Mahinda Rajapaksa in 2005 and the subsequent work on the "Mahinda Chintana" (MC) (Mahinda's Vision) and the second, the military defeat of the Tamil Tigers in May 2009. The question that arises is does either of these enable the government to address the particular issues of public administration and governance identified in this thesis?

First, it is worth repeating the key issues identified by this thesis. It was found that the key recommendations of the ARC were not properly implemented due to the lack of political and bureaucratic interest, resistance from pressure groups, unfavourable political circumstances, and the lack of proper institutional arrangements for implementation. Some of its recommendations were attempted through the constitutional Amendments, the $13^{\text {th }}$ and $17^{\text {th }}$ Amendments. However, because of inadequate implementation (lack of fiscal and human resources devolution and non appointment of the Commissioners for the Independent PSC (see Chapter 4 and 5) the expected results have not been achieved.

In addition, this thesis found a wide range of issues in the political system in the country: enormous powers of Executive President, lack of check and balances by the legislature over the functions of the executive, patronage and lack of discipline and leadership qualities. In the area of public administration this thesis found issues on the structure and institutions, personnel management, use of official languages, delivery of services, governance, financial management, regulatory and policy management. The lack of real devolution as stipulated in the $13^{\text {th }}$ Amendment, the main concern of the Tamils, led to many years of terrorism in the country. This thesis 
suggested several policy measures that might overcome these issues or least ameliorate them: to arrange the administrative structure logically and address institutional issues such as duplication and unclear functions and responsibilities in central and provincial governments, the large number of ministries with confused responsibilities and functions, and the plethora of loss making commercial PEs with duplication of functions, In addition, it suggested eliminating patronage and introducing meritocracy in personnel management functions. Further, it suggested introducing delivery of services in both official languages in order to sustain the recent war victory, promote social cohesion and long lasting peace. Similarly, it suggested reducing the present level of corruption by eliminating lack of transparency in public business, holding public officials accountable for their actions and introducing good governance practices in public management. Further, the thesis recommended introducing cohesive policies and regulatory strategies and introducing holistic approaches in government actions. It particularly emphasised the importance of reducing the power of the Executive President.

The election of the fifth President, Rajapaksa, and the ending of the 27-year war in the first four years of his leadership is a remarkable achievement. The President's economic and social philosophy speculated in the MC became the guiding policy document. The political circumstances of the day (weak leadership in the Opposition UNP, and the support of the JVP to Mahinda Rajapaksa) and the MC policy document provided ${ }^{79}$ the government with citizens' support to win the election and to defeat the LTTE in May 2009. The conclusion of the civil war created the possibility for further evolution of policies and reforms in the public sector. For example, meaningful devolution of power to sub-national level, providing equal opportunities to all communities to access SLPS and introducing meritocracy in all appointments in the public service including secretaries of ministries, heads of departments.

\footnotetext{
79 Address by President Rajapaksa at the ceremonial opening of Parliament, Sri Jayawardhanapura Kotte, May 19, 2009, same day the war is over, "it is necessary to recall at this time the statements in the historic Mahinda Chintana that policy statement that was placed before the people three years ago. The freedom of our country is supreme. I will not permit any separatism. I will also not permit anyone to destroy democracy in our country"
} 
This chapter discusses whether there are any policy developments in the area of public administration reforms due to these recent political upheavals since 2005 in SL and see whether those issues identified by the research have been addressed.

\subsection{Issues Identified}

\subsubsection{Political Issues}

As seen in Chapter 7 enormous powers of Executive President, lack of checks and balances by the Legislature over the Executive and the lack of will to reform the public sector by the political leaders and political patronage in public services were key issues identified by this thesis.

\subsubsection{Executive Presidency}

This thesis found that the enormous power of the Executive President is a hindrance to good governance in public management. Since 1994, there have been calls for the abolition of this system and it was discussed in political circles (Vijitha Herath, interview, 18.01.2008). In every Presidential election after 1994, the abolition of this system was one of the pledges of its candidates, but nothing happened once the candidate is elected. In 2005, the "Mahinda Chintana" pledged to change the Parliamentary Election System and to abolish of the Executive Presidency. As a first step, he proposed to present a Constitutional amendment through which the Executive President would be made answerable to the Parliament by virtue of holding such office. However, this is not yet fulfilled.

In the meantime, before the completion of his six year period (2005 December 2011), President Rajapaksa called for a presidential election on 23 December 2009, two- years before his term was over, and the election was held on 26 January 2010. The main candidates in this contest were President Rajapaksa from SLFP and General Fonseka, former Military Chief as the common opposition candidate. Winning over peace by establishing democracy would be priority of Fonseka's election pledge. It will be done by abolishing the Executive presidency, reduction of the large cabinet, eradication of corruption and waste and the implementation of the $17^{\text {th }}$ Amendment to the Constitution and increase of public servant salary by SLRs. 
10,000 were the main pledges of the Common Candidate among other things. The first three pledges were the major findings of this study to be addressed in the future (see Chapter 7). President Rajapaksa's pledges were: increase of public servant's salary by SLRs. 2500; cut down 'unnecessary powers' of the Executive President; and address the Tamils demand by a home grown solution. However, there were no clear statements regarding 'unnecessary powers' and 'his solution to Tamil problems'. Neither candidate came up with a clear plan in regard to the devolution of powers. The major implications of the Executive President system have been discussed in Chapter 3, 4 and 5. Presidential powers need immediate curtailment or abolition in order to strengthen democracy and good governance.

\subsubsection{Abolishing Patronage and Introducing Meritocracy}

The 'MC' does not talk about the introduction of meritocracy in all appointments in the SLPS but it promised to uplift the dignity of the public service and to take action to make permanent all those who have been recruited on casual and temporary basis. As discussed in Chapter 4 and 5, under the $17^{\text {th }}$ Amendment to the Constitution, public service personnel management functions including appointments, transfers, promotions and disciplinary control are entrusted to the Independent PSC and in relation to the Police Service, those functions are dealt by the Police Commission. However, as discussed in Chapter 4 and 5, these institutions are still defunct due to non-appointment of its Commissioners.

Ignoring the $17^{\text {th }}$ Amendment, the powers of the PSC and the Police Commission envisaged by the Constitutional Amendment were transferred to the Secretaries of Ministries by a circular ${ }^{80}$ signed by the Secretary to the Cabinet (see Chapter 5). Accordingly, the authority of decision making in public sector personal management functions were transferred to the Cabinet from an independent body. Political interference is possible because Secretaries of Ministries are appointed by the President and they are under the control and direction of their individual ministers (see Chapter 5). Whether the Secretary to the Cabinet or the Cabinet of Ministers has the authority to transfer the powers of the independent commissions, which were

${ }^{80}$ Office of the Cabinet of Ministers No. 09/1041/360/034 dated 25.06.2009 
endorsed by two thirds of majority votes in Parliament, to the secretaries of line ministries, is a matter for concern. It seems that there are legal implications in this situation.

The Opposition parties in particular have criticised these government actions saying that the Government violates good governance practices. The Opposition Common Candidate who contested in the Presidential Election on 26 January 2010 made a particular point about these problems and his ten points election manifesto pledged that he would implement the $17^{\text {th }}$ Amendment to the Constitution if he was elected. However, the PSC is still not operative and the Secretaries of ministries enjoy all the powers in relation to PSC's functions.

\subsubsection{Structural and Institutional Issues}

This thesis has argued that the lack of real devolution of powers to sub-national level was one of the root causes of the 27 years of LTTE terrorism in SL. Until 2005, successive governments and the LTTE were unable to reach an agreement with the devolution of powers to the sub-national level. Mahinda Rajapaksa, who was elected as the President in 2005, pledged in his ' $\mathrm{MC}$ ' manifesto to protect the unitary status and sovereignty of the country by eradicating LTTE, but there was no pledge in sharing more powers to the sub-national level. In other words, the MC does not contain a firm political solution to this national problem. The strategy adopted in eradicating LTTE was the war against the terrorists because President Rajapaksa firmly believed that terrorism should be crushed first in order to reach a political solution to the national problem.

At the same time the President established an All Party Representative Committee (APRC) chaired by Professor Tissa Vitharana, Minister for Science and Technology, to arrive at possible political solutions to the conflict, but the main Opposition, UNP, JVP and the TNA (Tamil party) did not participate in the committee meetings. A summary report of the APRC was submitted to the President in August 2009, but it was not published. The BBC (January 15, 2010) reports that "Mr Rajapaksa has now said he does not think any generally acceptable solution has yet been suggested". The 
$\mathrm{BBC}$ report further says that after the Presidential election ${ }^{81}$ incumbent President is going to put forward his own solution to the problem. In an interview, the Chair of the APRC said that "the government is planning to reactivate the APRC after the general election 2010, with a view to obtaining the participation of Tamils parties in the North and East in finding political solutions to the Tamil problem" (Vitharana, interview, February 17, 2010).

Since defeating the LTTE in May 2009, until this thesis was completed in July 2009 and this Post-Script Chapter written in early 2010 there has not been any policy development in regards to devolution of powers which is expected by the Tamils. One of the possible reasons for delay in real devolution might be instabilities caused by the final stage of war and the attendant large scale civilian casualties, and displacement. This situation has led the international community to accuse the SL Government of human rights violations. International groups (including the Tamil Diaspora) urged the UN to summon the SL government and military personnel before the International War Tribunal. Another possible reason for delay in real devolution might be that the Government also was busy with demining hundreds of thousands of landmines, which were buried by the LTTE, in the North in order to resettle the displaced people (about 300,000 in total). The international community also pressurised the government to resettle the displaced people in their original places without delay. In addition, the Government wants the participation of people of the North in the democratic process to select their Local Government members in order to reactivate local governments with a view to obtain local participation in the resettlement process, something that cannot be achieved until stability returns. Another possible reason for delay in devolution is that the government might want to give time to the healing process without making any policy changes soon after the completion of war.

\subsubsection{Equal Opportunities - Language Issues}

The other issue identified by this thesis was the lack of equal opportunities to access the public services by all communities. Therefore, the post war scenario created a

\footnotetext{
${ }^{81}$ Presidential election was scheduled to be held on 26 January 2010.
} 
situation for proactive reforms in the area of delivery of public goods and services. According to many people as SL moves from a post-war to a post-conflict era, it will need to find a political solution that involves power sharing, as well as pursuing development that is equitable and inclusive (personal observation). They say the government needs to take decisive steps towards reconciliation. In this regards, the implementation of the official language policy plays a key role. One of the key causes of the 30 year LTTE war was the language issue. The Tamils face many challenges due to the use of Sinhala language in the delivery of services by the majority of government institutions. They believed they were discriminated against by successive Sinhala regimes.

According to the most recent Language Resources Needs Assessment Survey conducted by the Official Languages Commission (OLC) which covered 50 state institutions, there were a very low percentage of officers proficient in Tamil serving in the public administration sector (Sunday Times, February 14, 2010). The report revealed in areas outside the north and east the percentage of officers proficient in Tamil was $9.5 \%$, compared with $18.1 \%$ officers proficient in Sinhala in the north and east. Sinhala is the language of administration in areas outside the north and east while Tamil is supposed to be the language of administration in these two areas. Base hospitals, police stations, local authorities, head offices and Divisional and District Secretariats are the institutions where language was found to be an obstacle to around $50 \%$ of members of the public questioned. Issues like filling of forms and communication with state institutions were the areas those surveyed faced hindrances. Even though in around $60 \%$ of state institution forms were printed in all three languages as the law stipulates, there were many institutions where this rule was not adhered to. There was also low compliance with regard to the display of name and sign boards, direction boards and information displays in the two official languages. The major implication due to lack of attention to these elements might be that further division of communities and de-motivation of the minority in participation of social and economic development. It is also a drawback for reconciliation and development of peace in the two main communities, Sinhala and Tamil. Communication gap between two communities, Sinhala and Tamil, still is a major concern in post-war scenario thus needs reforms as suggested in Chapter 7 


\subsubsection{Elimination of Corruption}

As mentioned in Chapter 4, public sector corruption and wastage was a major problem in the recent past. The ten-year action plan prepared by the Department of National Planning based on MC manifesto does not talk about corruption and wastage. However, the Opposition Common Candidate who contested the Presidential Election on 26 January 2010 categorically mentioned that public sector is corrupt and corruptrion should be eliminated. His ten point election manifesto pledged that he would take steps to eliminate corruption and wastage in the public sector once he is elected. He highlighted several examples of corruption. Mahinda Rajapaksa who was elected for the second time as the President of SL in January 2010 has promised to address this issue. However, the term of the Commission to Investigate Allegations of Bribery and Corruption ${ }^{82}$ came to an end on March 29, 2010 and the Commission is defunct until new appointments are made to it by the President on the recommendations of the $\mathrm{CC}$, which is yet to be reconstituted (ColomboPage News Desk, 13 Mar 2010).

The major implication once the Commission's term expires is that new complaints on alleged acts of bribery and corruption could not be investigated by the Commission and action could also not be taken in relation to ongoing investigations that would be concluded after March 29, 2010. If corruption issue is not properly addressed, it will lead to misuse of public resources. So that expected economic and social wellbeing cannot be harnessed.

\subsubsection{Implementation of Remaining ARC Recommendations}

Since 2005, the remaining ARC's recommendations which have been partially implemented or yet to be implemented (see Chapter 6) were:

Establishment of National Salaries and Cadre Commission in 2006 (see Chapter 4 4.3.2.1)

Linked Salaries to cost of living in 2006;

\footnotetext{
${ }^{82}$ The Commission to Investigate Allegations of Bribery and Corruption is yet another independent commission formulated under the $17^{\text {th }}$ Amendment to the Constitution and appointments to the commission are to be made on the recommendation of the $\mathrm{CC}$.
} 
Revised salaries to specific posts based on job classifications in 2007; and Introduced a uniform salary structure in 2007.

However, it should be noted that other issues which were explained in Chapter 7 have remained unaddressed since defeating the LTTE in May 2009. It can be argued therefore that there has been no significant policy development in the area of public administration reforms since 2005 .

\subsection{Conclusion}

This post-script Chapter reviewed whether there were any policy developments in the public sector management with the recent political developments of the country especially the election of President Rajapaksa in 2005 and the subsequent work on the "MC" and the military defeat of the LTTE in May 2009. It also reviewed whether major issues identified by this thesis have been addressed due to these new developments. It is revealed that the major issue, the real devolution of powers to sub-national level which was the major demand by the Tamil community, has not yet found any political solution since after defeating the terrorism in the country. In addition, it is revealed that there is no major policy development since winning the war in relation to the structural issues such as plethora of loss making PEs, and duplication of functions of the three layers of the government. The other issues such as abolition of patronage in personnel management functions, abolition of enormous powers of the Executive President and elimination of wastage and corruption in the public sector are yet to be addressed. However, the use of official languages, both Sinhala and Tamil, in delivery of services is vital for reconciliation and peace.

President wields enormous powers under SL's executive presidency system. With his re-election for a second term (to commence in November 2010), President Rajapaksa will rule the country for a total duration of 11 years until 2016. Added to this the UPFA coalition led by the President has a majority in parliament now. This provides him an unprecedented opportunity to take positive action including constitutional amendments, and to resolve the acrimonious issue of devolution of powers to Tamils. Thus he is at the helm at an important stage in SL's political history with the strength to solve the simmering ethnic confrontation and unite the nation. 


\section{References}

Aberbach J.D. \& Rockman B.A. (2002). Conducting and coding elite interviews. Political Science and Politics 35(4), 673-676.

Abeywardene H.A.P. (2007). Government, administration and justice. National Atlas Sri Lanka Survey Department, 25-27.

Abeywardene, H. A. P. (2006, April 21). Fostering a local government system in Sri Lanka: A new vision. Daily News, p. 4.

Abeywickrama, M. I. (2008, January 20). Burying COPE and COPA in the name of good governance. The Sunday Leader, p. 16 \&17.

Adam, C., Cavendish, W., \& Mistry, P. (1992). Adjusting privatisation: Case studies from developing countries. London, Jamaica \& USA: James Currey Ltd., Ian Randle Publishers Ltd. and Heinemann.

ADB. (2001). Special evaluation study on the privatisation of public sector enterprises: lessons for developing member countries. Retrieved December 20, 2007, from: http://www.adb.org/Documents/PERs/sst-stu-2001-15/sespublic-sector.pdf\#page $=31$

ADB. (2003). Accrual budgeting and accounting in government and its relevance for developing member countries, Retrieved September, 2, 2008 from:

http://www.adb.org/documents/reports/acrual_budgeting_accounting/accrual budgeting accounting.pdf.

ADB. (2004). Report and recommendation of the President to the Board of Directors on proposed loans to the Democratic Socialist Republic of Sri Lanka for the Fiscal Management Reform Programme.

ADB. (2004). Review of governance and public management for Sri Lanka.

Retrieved May 20, 2007, from: http://www.adb.org/Governance/sri-report

ADB. (2008). Sri Lanka: Fiscal Management Reform Program. Retrieved September 20, 2008, from: http://www.adb.org/Documents/Tranche-

Releases/SRI/36168-SRI-PRTR.pdf

Administrative Reforms Committee. (1986/88). Reports No. 1- 10. Colombo:

Department of Government Printing.

Amunugama, S. (1977). A Sociological analysis of present recruitment to the S.L.A.S. Economic Review, 3(2).

Appoints 75 year old as LankaPutra Bank chairman. (2008, January 20). The Sunday Leader, p. 22.

Auditor General. (2006, 2007, 2008). Annual Reports. Colombo: Auditor General's Department.

Bale, M., \& Dale, T. (1998). Public sector reform in New Zealand and its relevance to developing countries. The World Bank Research Observer, 13(1), 103-121. 
Borland, K. W. (2001). Qualitative and quantitative research: A complementary balance. New Directions for Institutional Research, 112, 5-13.

Boston, J. (1991). The theoretical underpinnings of public sector restructuring in New Zealand. In J. Boston, J. Martin, J. Pallot \& P. Walsh (Eds.), Reshaping the state: New Zealand's bureaucratic revolution (pp. 1-50). New York: Oxford University Press.

Boston, J., Martin, J., Pallot, J., \& Walsh, P. (1996). Public management: The New Zealand model. Auckland, Melbourne, New York, Toronto: Oxford University Press.

Bovaird, T., \& Loffler, E. (Eds.). (2003). Public management and governance. London and New York: Rutledge, Taylor and Francis Group.

Braibanti, R. (Ed.). (1966). Asian bureaucratic systems emergent from the British imperial tradition. Durham, N.C.: Duke University Press.

Call for a disciplined public service (2007, December 24). Daily News.

Case, W. (2007). Semi-democracy and minimalist federalism in Malaysia. In H. Baogang, G. Brian \& I. Takashi (Eds.), Federalism in Asia (pp. 124-143). UK, USA: Edward Elgar Publishing Limited.

Central Bank of Sri Lanka. (1993, 2002, 2004, 2005, 2006, 2007 \& 2009) Annual Reports . (1975). Review of the economy . (1998). Economic progress of independent Sri Lanka.

Ceylon. (1956). The Official Language Act (1956). Colombo: Department of Government Printing.

Ceylon. (1960). Parliament (Powers and Privileges) Act (1956 Revision). Sri Lanka: Department of Government Printing.

Chandrika admits committing 'three' mistakes as Lanka President. (2008, March 31). Retrieved from: www.lankanewspapers.com

Collins, C. (1951). Public administration in Ceylon. London, New York: Royal Institute of International Affairs.

Collins, C. (1966). Ceylon: The imperial heritage. In R. Braibanti (Ed.), Asian bureaucratic systems emergent from the British imperial tradition (pp. 444549). Durham, N.C.: Duke University Press.

ColomboPage Sri Lanka (March 13, 2010). http://www.colombopage.com/archive_10/Mar1268497074JV.html

Commission of Inquiry on Local Government Reforms. (1999). Report of the Commission of Inquiry on Local Government Reforms. Colombo: Department of Government Printing.

Commission to Investigate Allegations of Bribery or Corruption. (2005, 2009). Annual Reports. 
Committee of the Citizens Consultation on Free \& Fair Elections and Depoliticisation of Key Institutions. (1998). Report of the Citizen Consultation on Free and Fair Elections and De-politicisation of Key Institutions. Colombo: United National Party.

Committee on Public Accounts. (2007). Interim report. Sri Jayewardenepura Kotte: Sri Lanka Parliament.

Committee on Public Enterprises. (2007). First and second reports Sri Jayewardenepura, Kotte: Sri Lanka Parliament.

Committee to Study the Operation of Provincial Councils in Sri Lanka. (1996). Provincial councils: operational experience of devolution. Colombo: Ministry of Co-operatives, Provincial Councils, Local Government \& Indigenous Medicine.

Cresswell, J. W. (2003). Research design. Thousand Oaks, London and New Delhi: SAGE Publications.

De Alwis, R. K. (2000). Identifying the constraints to effective operation of employee performance appraisal systems (PA): Australia and Sri Lanka. Unpublished Master's Dissertation. Australian National University.

De Silva, C. R. (2005). Sri Lanka in 2005: Continuing political turmoil. Asian Survey, 46(1), 114-119.

De Silva, K. M. (1981). A history of Sri Lanka. London: C. Hurst.

. (Ed.). (1993). Sri Lanka: problems of governance. Sri Lanka, International Centre for Ethnic Studies.

De Votta, N. (2003). Sri Lanka in 2003: seeking to consolidate peace. Asian Survey, 44(1), 44-49. . (2004). Sri Lanka in 2004: enduring political decay and a failing peace process. Asian Survey, 45(1), 98-104.

Department of Census \& Statistics. (2002). Statistical pocketbook. . (2006). Census of public \& semi-government sector employment. . (2009).Department of Statistics. Retrieved February 23, 2009 from: http://www.statistics.gov.lk/misc/overview.htm

Department of Management Services. (2002, 2004). Suspension of recruitments to the public service, provincial public services including local authorities, public corporations, statutory boards and government owned companies and abolition of existing vacant posts in such organization. Circulars No. 16 October 1, 2002 and No. 23 September 8, 2004.

Department of Public Enterprises. (2003). Code of best practices for public enterprises in Sri Lanka and the implementation guidelines. . (2004). Report on the review of performance of public enterprises by National Review Committees 2003. 
(2005). Financial performance. Retrieved March 16, 2009, from: http://www.treasury.gov.lk/FPPFM/ped/commercialforward.htm

Denzin, N. K., \& Lincoln, Y. S. (Eds.). (2005). The SAGE handbook of qualitative research (3rd ed.). New Delhi, London: Sage Publications.

Devendra, T. (2008, January 10). Do we need salaries commissions? The Island.

Dharmadasa, K. N. O. (Ed.). (1996). Language policy in multi-ethnic society: the case of Sri Lanka. Kandy: International Centre for Ethnic Studies

Dissanayake, D. (2008, January 27). VAT scam: state unfolds the big sham. The Sunday Times, p. 2.

Dolowitz D. and Marsh D. (1998). Policy transfer: a framework for comparative analysis. In M. Minogue, Polidano, C., and Hulme, D. (Ed.), beyond the new public management: changing ideas and practices in governance (pp. 38-56). UK, Northampton, MA, E Elgar: Cheltenham.

Dunham, D., \& Kelegama, S. (1997). Stabilization and adjustment: a second look at the Sri Lankan experience, 1977-93. The Developing Economies, 35(2), 166184.

Eastern Provincial Council. (2009). Short history. Retrieved March 13, 2009, from: http://www.ep.gov.lk/

Economist. (2008, February 3). 60 years after independence: nation building need of the hour. The Sunday Times.

Economist. (2009, April 26). Are we heading towards a debt trap? Retrieved April 26, 2009, from http://www.sundaytimes.lk/090426/Columns/eco.html

Fernando, K. (2009). Sri Lankan students protest against education privatisation. Retrieved May 23, 2009, from: http://www.wsws.org/articles/2009/may2009/sled-m22.shtml

Fernando, L. (2005). The essence and direction of public administration reforms. In M. Sarvananthan (Ed.), Post-1977 Period - economic reforms in Sri Lanka (pp. 135-180). Colombo: International Centre for Ethnic Studies.

Fernando, N. (1999). Sri Lanka in 1998: political stalemate and economic drift. Asian Survey, 39(1), 185-190.

FR petitions against Sri Lanka Ministry of Education over principals appointments. (2007). Retrieved October 18, 2007, from: http://www.colombopage.com/

Galal, A. (1991). Public enterprises reform: lessons from the past and issues for the future. Washington D.C.: World Bank.

Gamage, C. (n.d.). Decentralisation of the government machinery in Sri Lanka: some major events: Handout - Induction Training Programme of SLAS 1984.

Ganewatte, S. N., \& Ferdinando, S. (2007, December 19). Inland Revenue Dept. detected fraud long before AG. The Island, p. $1 \& 6$.

Garry, D. E. (2004). Doing research in the real world. London: Sage Publication. 
Goonawardene, H. D. L. (2007, May 21). Lecture delivered on "The role of Public Service Commission under the 17th Amendment to the Constitution". Colombo: Sri Lanka Foundation Institute

Government of Sri Lanka (2007). Government ministries. Retrieved May 20, 2008, from: http://www.priu.gov.lk/ . (2007). ICT policy and procedures for the government. Retrieved February 15,2009 , from:http://www.icta.lk/index.php?option=com_content $\& v i e w=\operatorname{article} \& \mathrm{id}=2$ $17 \&$ Itemid=109\&lang $=$ en . (2009). Ministries of Sri Lanka government. Retrieved February 11, 2009, from: http://www.gov.lk/public/groups.asp?xi=91\&groupname $=\& \mathrm{cp}=2 \& \mathrm{sk}=$

Grbich, C. (2007). Qualitative data analysis: an introduction. London, Thousand Oaks \& New Delhi: SAGE Publications.

Guiza, E. C., \& Nem Singh, R. P. (2003). Enhancing the staff performance appraisal system of the Coconut Research Institute, Sri Lanka. CRI.

Gunasena, S. (2006). Language Policy: An overview of the Sri Lankan experience. In A. Jayewardene (Ed.), Perspectives on national integration in Sri Lanka (pp. 229-259). Colombo Ministry of Constitutional Affairs \& National Integration.

Gunawardena, A. S. (n.d). Beyond legal and administrative constraints confronting provincial councils: issues in devolution and governance change in Sri Lanka. Colombo: Sri Lanka Institute of Local Governance. . (1984). Decentralisation for development - re-appraising Sri Lanka's experience: Handout - Induction Training Programme of SLAS 1984.

Harris, R. L., \& Kearney, R. N. (1963). A comparative analysis of the administrative systems of Canada and Ceylon. Administrative Science Quarterly, 8(3), 340360.

Heinrich, C. J. (2003). Measuring public sector performance and effectiveness. In G. B. Peters \& J. Pierre (Eds.), Handbook of Public Administration (pp. 25-34.). London, Sage Publications.

Hennayake, S. K. (1989). The Peace Accord and the Tamils in Sri Lanka. Asian Survey, 29(4), 401-415.

Herath, H. M. A. (1991). Decentralisation for rural development in Sri Lanka. Carleton, Ottawa.

Herath, H. M. T. N. R. (2006). Role of the state of Sri Lanka in the context of selected Asian countries: Identification of the drawbacks. Seminar 7, August 17, Australia. University of Wollongong.

Hughes, O. E. (1994). Public management and administration. New York: St.Marin's Press.

Ians. (2008). Former Sri Lankan president fined by Supreme Court. Retrieved

October 8, 2008, from: http://www.newstrackindia.com/newsdetails/25966 
ICTA. (2009). Re-engineering government. Retrieved January 23, 2009 from: http://www.icta.lk/index.php?option=com_content\&view=article\&id=63\&Ite $\underline{\text { mid}=40 \& l a n g=e n}$ . (2007, August). Birth certificates in 10 minutes The Catalyst, 11.

Jennings, I. (1954). Politics in Ceylon since 1952. Pacific Affairs, 27(4), 338-352. . (1949). The Constitution of Ceylon. London: Geoffrey Cumberlege, Oxford University Press.

Kannangara, N. (2008, August 6). The govt's educational nightmare. Retrieved August12, 2008, from: http://www.themorningleader.lk/20080806/spotlight.html

Kappagoda, N. (2004). Public debt: institutional issues. In S. Kelegama (Ed.), Economic policy in Sri Lanka: issues and debates New Delhi/Thousand Oaks/London: Sage Publications.

Katugampola v. Commissioner-General of Excise and Others - SLR - 207, Vol 3 of 2003 LKCA 83; (2003) 3 Sri LR 207 (23 October 2003)

Kavirathne, I. (2008, January 27). Grade 1 admissions: mixed reception to parents' claims. The Sunday Times, p. 2.

Kearney, R. N. (1966). Ceylon: the contemporary bureaucracy. In R. Braibanti (Ed.), Asian bureaucratic systems emergent from the British imperial tradition (pp. 485-549). Durham, N.C.: Duke University Press.

. (1973). The politics of Ceylon (Sri Lanka). Ithaca and London: Cornell University Press.

. (1975). Educational expansion and political volatility in Sri Lanka. Asian Survey, 15(9), 727-744.

Kelegama, S. (1992). Privatisation: The Sri Lankan experience. Colombo: Institute of Policy Studies.

Kettl, D. F. (2000). The global public management revolution: A report on the transformation of governance. Washington, D.C.: Brookings Institution Press.

Knight-John, M. (2002). The institutional framework for regulation and competition in Sri Lanka. U.K.: University of Manchester.

Knight-John, M., \& Athukorala, P. P. A. W. (2005). Assessing privatisation in Sri Lanka: distribution and governance. Retrieved August 26, 2007, from: http://www.cgdev.org/doc/Privatization/ch\%2012.pdf

Knight-John, M., \& Rajapakse, A. (2005). Effective states and engaged societies: the case of Sri Lanka, 1-44. Retrieved February 12, 2008 from: http://siteresources.worldbank.org/AFRICAEXT/Resources/Sri_Lanka.pdf.

Kovilagodage, J. (2009, June 9). Sri Lanka activist targets 40 privatizations. Retrieved June 10, 2009,from:http://www.lankabusinessonline.com/fullstory.php?nid=5790536

Laking, R. (1995). Developing a culture of success. Public administration and development 15, 283-294. 
Leitan, G. R. T. (1979). Local government and decentralised administration. Colombo: Lake House.

. (1992). The system of provincial councils in Sri Lanka: centre - province relations. Sri Lanka: Centre for Regional Development Studies.

Lilleker, D. G. (2003). Interviewing the political elite: navigating a potential minefield. Politics 23(3), 207-214.

Lips, M. (2008). Before, after or during the reforms? Towards information-age government in New Zealand. Policy quarterly, 4(2), 21-25.

Lowndes, V. (1996). Varieties of new institutionalism: a critical appraisal, Public Administration, 74, 181-197.

Marasingha, M. L. (1988). Ethnic politics and constitutional reform: The Indo-Sri Lanka Accord. The International and Comparative Law Quarterly, 37(3), 551-587.

Marga Institute. (1995). Policy dialogue - administrative reforms. Colombo: Marga Institute, Sri Lanka.

Marsh D. \& Stoker G. (1995). Theory and methods in political science, Macmillan Press Ltd, London.

Marshall, C., \& Rossman, G. (2006). Designing qualitative research. Thousand Oaks, London, New Delhi: SAGE Publication.

Mason, J. (2002). Qualitative researching. London, Thousand Oaks and New Delhi: SAGE Publications

Matthews, B. (1978). Recent developments in Sri Lanka politics. Pacific Affairs, 51(1), 84-100.

(1982). District Development Councils in Sri Lanka. Asian Survey, 22(11), 1117-1134.

(1989). Sri Lanka in 1989: Peril and good luck. Asian Survey, 30(2), 144149.

Maxwell, J. A. (1996). Qualitative research design: an interactive approach. London, New Delhi: SAGE Publications.

Mayan, M. J. (2001). An introduction to qualitative methods. Canada: International Institute for Qualitative Methodology.

Maykut, P. S., \& Morehouse, R. (1994). Beginning qualitative research: A philosophic and practical guide. London, Washington, D.C.: Falmer Press

McCourt, W. (2001). Finding a way forward on public employment reform: a Sri Lankan case study. Retrieved December 12, 2006, from: http://www.gsdrc.org/docs/open/CC99.pdf. . (2005). Patrons versus Weberians in the Sri Lankan civil service. Management in development, Working Paper Series, 1-27. Retrieved November 15, 2006 from: http://www.sed.manchester.ac.uk/idpm/research/publications/wp/mid/docume nts/mid_wp13.pdf 
'Mihin Lanka financial terrorism' exposed in parliament. (2008, September 23).

Retrieved February 16, 2009, from:

http://www.lankaenews.com/English/news.php?id=6425

Miles, M. B., and Huberman, A. M. (1994). Qualitative data analysis. London: Sage.

Minichiello V. Aroni R. Timewell E. and Alexander 1. (1995) In-depth

Interviewing, 2nd edition, Sydney Longman Australia, Chapters 4, 5 and 8.

Ministry of Education. (2009). Preliminary report - School Census - 2006. Retrieved May 4, 2009, from:

http://www.statistics.gov.lk/education/SUMMARY\%20TABLES\%202006.p $\underline{\mathrm{df}}$

Ministry of Employment and Labour. (n.d). National productivity policy for Sri

Lanka: the public sector component.

Minister of Finance and Planning Sri Lanka. (2005 \& 2006). The budget speeches. (2006). Budget-2006: Statements under the Fiscal Management

[Responsibility] Act No. 3 of 2003. Retrieved December 23, 2008, from: http://www.treasury.gov.lk/FPPFM/fpd/pdfdocs/budget2006dec/Fiscal\%20St rategy\%20Statement\%20English\%20\%202006\%20dec.pdf

. (2005, 2006, 2007 \& 2008) Annual reports. Retrieved October 10, 2008, from:

http://www.treasury.gov.lk/FPPFM/fpd/pdfdocs/annualreports/annualReport2 006.pdf (2008, 2009). Estimates.

Ministry of Local Government Housing and Construction. (1981). Gramodaya mandala handbook. Colombo: Department of Government Printing.

Ministry of Policy Development and Implementation. (2007, May 23). Decentralised Capital Budget, Circular No. SEC/MPI/043, 2007.

Ministry of Provincial Councils and Local Government. (2007). Performance and 2008 future plans.

Ministry of Public Administration. (1998, 2000). Performance appraisal of public officers - Circular No. 07/1998, 08/1998, 09/1998, and 02/2000, Colombo.

Ministry of Public Administration and Home Affairs. (2004 \& 2005).

Implementation of the Public Management Assistants' Service, Circular No. 10/2004 \& 01/2005. Colombo.

(2008). The Divisional Secretary cadre: provincial administration division.

Ministry of Public Administration Provincial Councils \& Home Affairs. (1990).

Guidelines for decentralised planning, budgeting and programme co-

ordination. Colombo.

(2005, 2006). Combined Service Circulars No. 01/2005 and 15/2006. 
More war victory celebrations in Sri Lanka. (2009, January 9). Retrieved February 8, 2009, from:

http://www.colombopage.com/archive_09/January9184646RA.html

Moore, M. (1990). Economic liberalisation versus political pluralism in Sri Lanka. Modern Asian Studies, 24(2), 341-383.

Nadarajah, S. (1997). Evolution of administrative reforms. In M. Somasundram (Ed.), The Third Wave: governance and public administration in Sri Lanka (pp. 239-262). Colombo: International Centre for Ethnic Studies

National Council for Administration Sri Lanka. (2006). Compensation reforms and salary system integration. Colombo 03: Resources Development Consultants Limited.

National Productivity Secretariat of Sri Lanka. (2004, 2005) Annual reports

No time to debate 21 ministries in next year's budget. (October 26, 2008). Retrieved October 31, 2008, from:

http://sundaytimes.lk/081026/News/sundaytimesnews_02.html

Oberst, R. (1985). Democracy and the persistence of westernized elite dominance in Sri Lanka. Asian Survey, 25(7), 760-772.

(1986). Administrative conflict and decentralisation: the case of Sri Lanka. Public Administration and Development, 6(2), 163-174.

Official Language Commission of Sri Lanka. (2005). Memorandum of recommendations.

Organisation of Professional Associations of Sri Lanka. (2007). Reawakening Sri Lanka as paradise isle, Colombo, $\mathrm{BMICH}$

Osborne, D., \& Gaebler, T. (1992). Reinventing government: how the entrepreneurial spirit is transforming the public sector. New York, N.Y.: Plume.

Osborne, S. P., Bovaird, T., Martin, S., Triker, M., \& Waterston, P. (1995). Performance management and accountability in complex public programmes. Financial accountability and management, 11(1), 19-37.

Outgoing Sri Lankan Chief Justice calls for a Sri Lanka with one people. (2009, June 6). Retrieved June 6, 2009, from: http://www.asiantribune.com/?q=node/18227

PAC takes Inland Revenue Department to task. (2007, November 30). Daily Mirror, p. A9.

Parliament of Sri Lanka. (2008). Handbook on Parliament. Retrieved April 6 (2009), from: www.parliament.lk

(2008). Committees. Retrieved October 24, 2008, from: http://www.parliament.lk/committees/special_purposes.jsp

(September 24, 2001). Parliamentary debates: official report (Hansard). Vol.138. 
Patton, M. Q. (2002). Qualitative research \& evaluation methods. Thousand Oaks, London and New Delhi: SAGE Publications.

Perera, S. (2007, January, 15). All public institutions must be restructured Daily Mirror, p. A9.

Phadnis, U. (1984). The political order in Sri Lanka under the UNP regime: Emerging trends in the 1980s. Asian Survey, 24(3), 279-295.

Pollitt, C. (2003). Public management reform: reliable knowledge and international experience. OECD Journal on Budgeting, 3(3), 122-136.

Pollitt, C., \& Bouckaert, G. (2000, 2004). Public management Reform: A comparative analysis. New York: Oxford University Press.

Presidential Commission on Youth. (1990). Report of the Presidential Commission on Youth. Colombo: The Department of Government Printing

President removes the Bribery chief. (2008, February 20). LankaNewspapers.com, from http://www.lankanewspapers.com/news/2008/2/24939.html

Presidential Secretariat Sri Lanka. (1998). Performance appraisal guidelines for staff officers.

Project Team for Establishment of a public debt management office. (2004). Existing debt management arrangement. Colombo: Ministry of Finance.

Public Enterprises Reform Commission. (2004). Annual report.

Raadschelders, Jos C.N. (2009). Is American public administration detached from historical context? On the nature of time and the need to understand it in government and its study, The American Review of Public Administration xx(x) online first, published on August 31, 2009.

Rahman, T. (2005). Parliamentary control and government accountability in Sri Lanka: the role of parliamentary committees. Retrieved January 20, 2009, from http://www.basas.ac.uk/conference05/rahman,\%20taiabur.pdf

Rajapaksa, M. (2005). Mahinda Chintana Retrieved from: http://www.priu.gov.lk/mahindachinthana/MahindaChinthanaEnglish.pdf.

Ramanayake, W. (2008, September 9). SC orders immediate salary increment for teachers. Daily News.

Ranasinghe, S. W. (1992). Devolution and administrative innovation: the case of Divisional Secretariat in Sri Lanka. Unpublished manuscript, Colombo: Postgraduate Institute of Management

Rao, P. V. (1988). Ethnic conflict in Sri Lanka: India's role and perception. Asian Survey, 28(4), 419-436.

Ratnasiri v. Ellawala, Court of Appeal Sri Lanka No: 16/2004.

Reforming the public service. (2007, December 4). Daily Mirror, p. A8.

Rhodes, R.A.W. (1995), The Institutional Approach, In Marsh D. \& Stoker G. (Ed.), Theory and Methods in Political Science, Macmillan Press Ltd, London 
Rondinelli D. A., Nellis J.R, \& Cheema G.S. (1983). Decentralization in developing countries: a review of recent experience. Washington D.C.: World Bank.

Root, Hodgson, \& Vaughan-Jones. (2001). Public administration reform in Sri Lanka. International Journal of Public Administration, 24(12), 1357-1378.

Rupasinghe, K. (2007). The impact of language rights violations in Sri Lanka 19562007. DailyMirror, p. A9.

Ryan, B. (2006). Managing for outcomes: understanding clients. Policy Quarterly, 2(4), 39-46.

Salaries and Cadre Commission (1958-61). Report of the Salaries and Cadre Commission: Colombo. Department of Government Printing.

Salih, R. (2000). Privatisation in Sri Lanka. Retrieved December 27, 2006, from: http://wwwilomirror.cornell.edu/public/english/region/asro/newdelhi/downlo ad/privatzn.pdf

Samarasinhge, S. W. R. D. A. (2008, January 23). Grade One Admission Policy. The Island, p. 5.

Schaffer, H. B. (1995). Sri Lanka in 1995: a difficult and disappointing Year. Asian Survey, 36(2), 216-223.

Schick, A. (1996). The spirit of reform: managing the New Zealand state sector in a time of change: A Report prepared for the State Service Commission and the Treasury, New Zealand.

(1998). Why most countries should not try New Zealand reforms. The World Bank Research Observer, 13(1), 123-131.

Schwartz H. and Jacobs J. (1979) Qualitative Sociology, New York, Free Press, Part I Reality Reconstruction: What it is and why do it?; Part II: Reality Reconstruction: How to do it.

Scott J. (2000), Rational Choice Theory, In G. Browning, A. Halcli, \& F. Webster. Understanding contemporary society: theories of the present, Saga Publications. Retrieved from http://privatewww.essex.ac.uk/scottj/socscot7.htm

Secretary to the Cabinet. (2007). Note to the Cabinet Sub-Committee on establishment matters: Powers over the public service - PSC vs. Cabinet, (pp. 1-3). Colombo.

Senevirathne, D. G. P. (1984). Language and administration. Sri Lanka Journal of Development Administration, 1(1-12), 40-47.

Shastri, A. (1992). Sri Lanka's provincial council system. Asian Survey, 32(8), 723743.

(2001). Sri Lanka 2001: Year of reversal. Asian Survey, 42(1), 177-182.

. (2002). Sri Lanka in 2002: turning the corner? Asian Survey, 43(1), 215221.

Singer, M. (1990). New realities in Sri Lankan politics. Asian Survey, 30(4), 409425. 
(1991). Sri Lanka in 1991: Some surprising twists. Asian Survey, 32(2), $168-174$.

Sirisena squabbles with Charmal to sell water. (2008, September 6,). Retrieved September 12, 2008, from:

http://www.lankatruth.com/News/Full_Story_Page/2008/September/06/2008 0906_02.htm

Sirivardana, S. (2004). Innovative practice amidst positive potential for paradigm shift: The case of Sri Lanka. In P. Wignaraja \& S. Sirivardana (Eds.), ProPoor growth and governance in South Asia New Delhi, Thousand Oaks, Calif: SAGE Publications India Pvt. Ltd.

Six Sigma. (2007). 5 S. from: http://www.isixsigma.dom/dictionary/55-486htm

Slater, R. (1997). Approaches to strengthening local government: lessons from Sri Lanka. Public Administration and Development, 17(2), 251-265.

SLTB overstaffed but short of drivers. (2007, August 14). The Island.

Somasundram. (1997). The Third Wave: Governance and public administration in Sri Lanka. Colombo and New Delhi: International Centre for Ethnic Studies and Konark Publishers.

Sri Lanka. (1955). The Official Secret Act (1955). Colombo: Department of Government Printing.

. (1972, May 22). The Constitution of Sri Lanka (Ceylon) 1972. Sri Lanka:

Department of Government Printing.

. (1978, August 31). The Constitution of the Democratic Socialist Republic

of Sri Lanka 1978. Sri Lanka: Department of Government Printing.

. (1980). Development Councils Act (1980). Colombo: Department of

Government Printing.

. (1985). Establishments Code part 1 and 11. Sri Lanka: Department of

Government Printing.

. (1987, November 14). Pradeshiya Sabhas Act (1987). Sri Lanka:

Department of Government Printing.

. (1987, November 14). Provincial Councils Act (1987). Sri Lanka:

Department of Government Printing.

. (1987, November 14). The 13th Amendment to the Constitution of 1978.

Sri Lanka: Department of Government Printing.

. (1992). The transfer of powers (Divisional Secretary) Act No. 58 of 1992.

Sri Lanka: Department of Government Printing.

. (2001, October 3). The 17th Amendment to the Constitution of 1978. Sri

Lanka: Department of Government Printing.

. (2003, July 02). Delegation of authority by the Public Service Commission:

Gazette No.1295/26 Sri Lanka: Department of Government Printing.

. (2005, December 24). Minute of the Public Management Assistants'

Service: Gazette No.1372/23 Sri Lanka: Department of Government Printing. 
. (2005, November 14). Minute of the Sri Lanka Administrative Service:

Gazette No.1419/3, Sri Lanka: Department of Government Printing.

. (2007, January 29). The functions of the ministers, Gazette No. 1482/9, Sri

Lanka: Department of Government Printing.

.(2006, May 9). Establishment of the National Salaries and Cadre

Commission: Gazette No. 1444/8 Sri Lanka: Department of Government Printing.

Sri Lanka Government suspends Colombo Municipal Council (2008). Retrieved November 26, 2008, from:

http://www.colombopage.com/archive_08/October29172238SL.html

SLIDA. (1983). Report of a colloquium on administrative reforms June 16-17 Policy Analysis Division.

Sri Lanka President, a dictator awaiting, says main opposition. (2008) Retrieved

May 9, 2008, from: http://lankanewspapers.com/new/index.jsp

Sri Lanka rocked by court ruling against John Keels holdings. (July 24, 2008).

Retrieved August 23, 2008, from:

http://www.lankabusinessonline.com/fullstory.php?nid=1133984571

The Speaker airs views on national issues. (2007, December 28). Daily Mirror.

Thelen, K, (1999). Historical institutionalism in comparative politics, Annual Review Political Science, (2), 369-404.

Transparency International, Corruption Perception Index 2009, Retrieved from http://www.transparency.org/policy_research/surveys_indices/cpi/2009/what _S_new_in_cpi_2009

UNDP. (1990). Programme for the improvement of public sector management: Government of Sri Lanka. Colombo: UNDP.

Unqualified teachers an obstacle to education. (2007, December 1). Daily Mirror, p. 8.

Uswatta-arachchi. (2008, January 23). Jumbo Cabinet - Jumbo Peanuts! The Island, p. 3 .

Wanasinghe, S. (1994). Activating the administrative reform process in Sri Lanka.

Colombo: Institute of Policy Studies.

(2001). The implications of the changing role of governance in Sri Lanka.

Colombo: Institute of Policy Studies.

(2005). Common Country Assessment (CCA) - public administration.

Unpublished memo.

Warnapala, W. W. A. (1973). Sri Lanka in 1973: a test for both rulers and the ruled. Asian Survey, 14(2), 148-156. 
(1974). Civil service administration in Ceylon: a study in bureaucratic adaptation. Colombo: Department of Cultural Affairs.

(1979). Sri Lanka 1979: new stresses in the economy and the polity. Asian Survey, Part II, 20 (2), 206-216.

(1979). Sri Lanka 1978: reversal of policies and strategies. Asian Survey, 19(2), 178-190.

(2004). Parliament and public accountability in Sri Lanka. Colombo:

Godage International Publishers (PVT) LTD.

Weerakkody, D. (2007, January 20). Can COPE stop the rape of public institutions? Daily Mirror, p. B3.

(2007, June 2). COPE report: high time to address core issues. Daily Mirror p. B3.

Weerakoon, B. (2004). Rendering unto Caesar: a fascinating story of one man tenure under nine prime ministers and presidents of Sri Lanka. Colombo, New Dawn Press, Inc. UK, USA, India: Vijitha Yapa Publications.

Weerakoon, T. S. (1995). Public enterprises pathology: Sri Lanka's experience in perspective. Asian Journal of Public Administration, 17, 302-321. Retrieved October 29, 2007 from http://sunzi1.lib.hku.hk/hkjo/view/50/5000103.pdf.

Weerasooria, W. (2004). The law governing public administration in Sri Lanka. Colombo: Postgraduate Institute of Management

Weizacker, V. E. U., Orang, R. Y., Marthias, F., \& Marianne, B. (Eds.). (2005). Limit to privatisation: how to avoid too much of a good thing. U.K. and USA: Earthscan.

Western Provincial Council. (2009). Western Province of Sri Lanka. Retrieved March 13, 2009, from http://www.wpc.gov.lk/

Wickramasinghe, N. (2009). Sri Lanka in 2008: waging war for peace. Asian Survey, 49(1), 59-76.

Wickramasinghe, W. (2008, January 24). Politicisation of society and salaries and perks of MPs. The Island, p. 11.

(2008, January 23). Politicisation of society and salaries and perks of MPs. The Island, p. 10.

Wignaraja P. \& Sirivardana S. (2004). Pro-poor growth and governance in South Asia New Delhi, Thousand Oaks, Calif: SAGE Publications India Pvt.Ltd.

Wijesinghe, D. (1997). Asian perspectives - case of Sri Lanka. Paper presented at the Roundtable Conference on Administrative Reform, India.

(1998). Governance for the XX1 st century: learning lessons from the public service reforms - Sri Lanka. Paper presented at the International Conference, Ottawa, Canada.

Wijeweera, B. S. (1988). A colonial administrative system in transition: the experience of Sri Lanka. Colombo: Marga Publications.

(1989). Policy development and administrative changes in Sri Lanka: 19481987. Public Administration and Development, 9(3), 287-300. 
(2006). The dynamics of a constitutional amendment: A case study of the 17th Amendment to the Constitution of Sri Lanka. Paper presented at the Sri Lanka Association for the Advancement of Science Proceedings of the 62nd Annual Session, Colombo.

Wilson, A. J. (1974). Politics in Sri Lanka. Bristol: Western Printing Services LTD. (1980). The Gaullist system in Asia: the Constitution of Sri Lanka (1978). London and Basingstoke: The Macmillan Press LTD

World Bank. (2000). Sri Lanka: recapturing missed opportunities. Retrieved November 25, 2006, from: http://siteresources.worldbank.org/SRILANKAEXTN/Resources/Missedopportunities/full_report.pdf.

(2003). Country financial accountability assessment study. Colombo: South Asia Region Financial Management Unit

(2004). Sri Lanka development policy review. Retrieved December 20, 2006, from:

http://siteresources.worldbank.org/INTSRILANKA/Resources/293961LK0re vised.pdf

(2006). Decentralisation in Sri Lanka. Retrieved November 15, 2006, from: www.web.worldbank.org/WBSITE/EXTERNAL/COUNTRIES/SOUTHASI $\underline{\mathrm{AEXT} / \mathrm{E}}$

Wriggins, H. W. (1961). Impediments to unity in new nations: the case of Ceylon. The American Social Science Review, 55(2), 313-320.

(1981). Sri Lanka in 1980: the year of constraints. Asian Survey, 21(2), 203211.

(1982). Sri Lanka in 1981: year of austerity, development councils, and communal disorders. Asian Survey, 22(2), 171-179. 


\section{Appendix 1: Cabinet and Ministries}

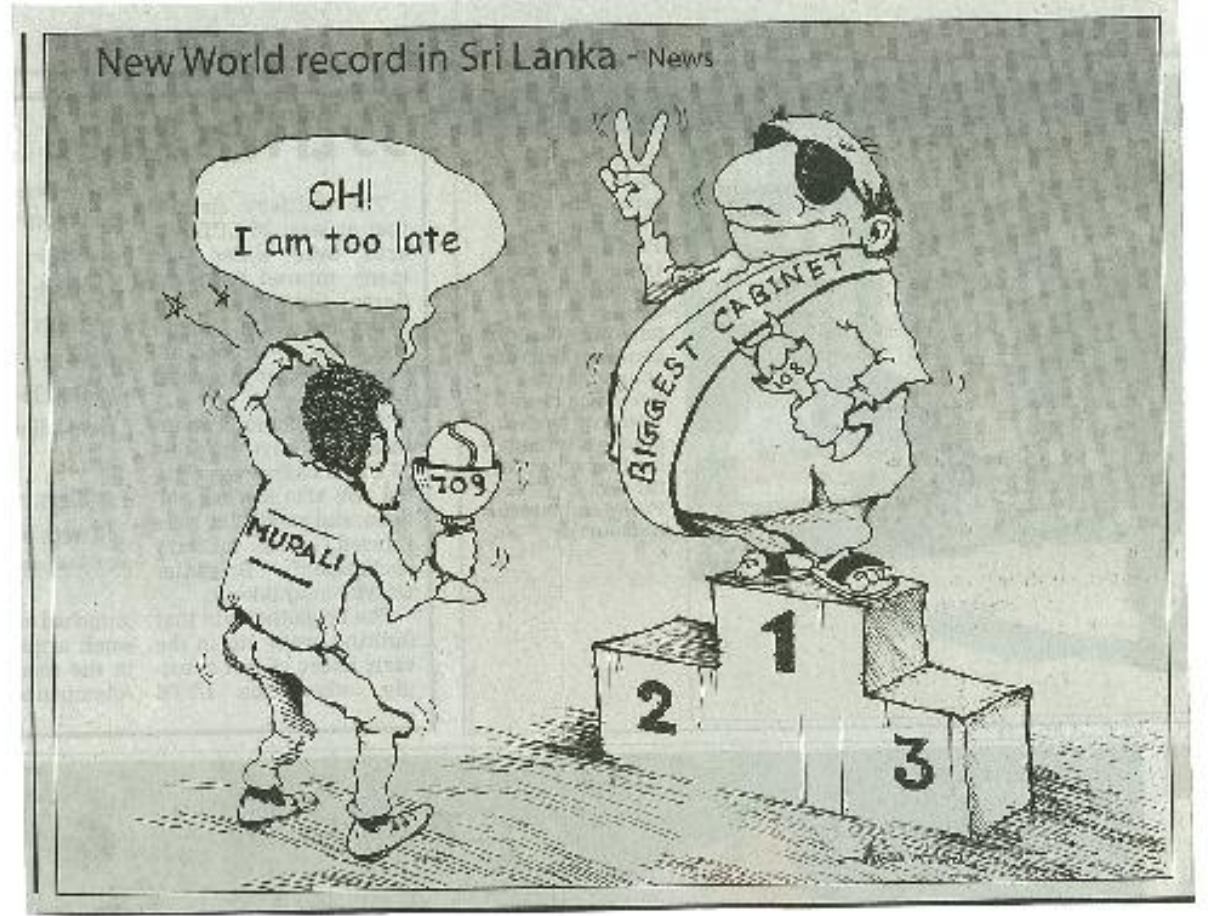

Seurce: Ariontha (2oot, December 4 ), Daily maror

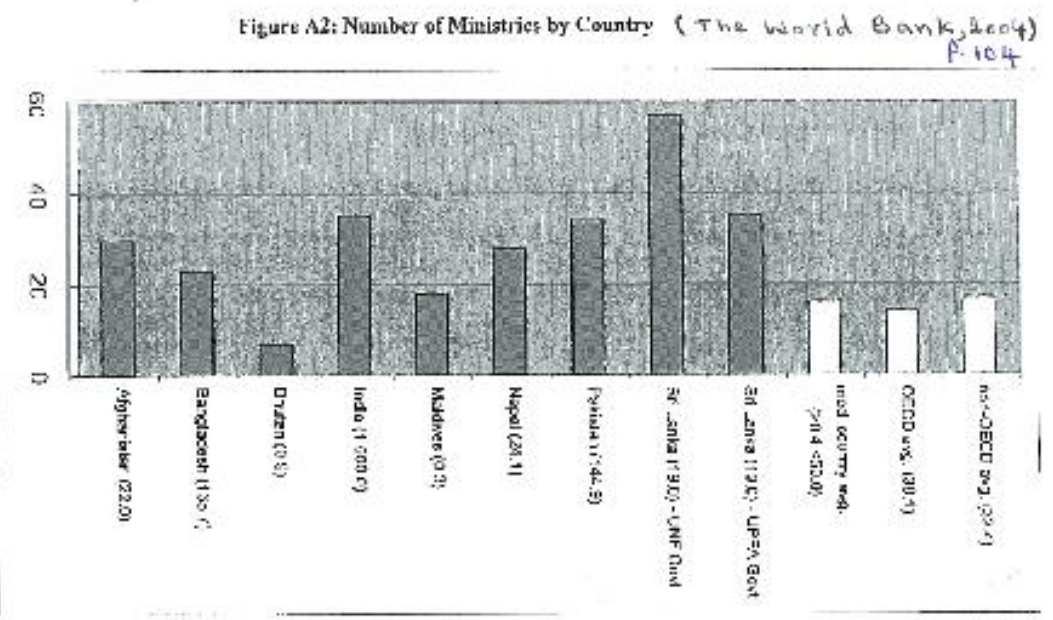




\section{Appendix 2: Interview Questions}

\section{Questionnaire to the Chairman of the}

Administrative Reform Committee

\section{General questions}

Are you aware of the administrative reform initiatives in Sri Lanka since independence? What are they?

What have been the primary motivations (drivers) for administrative reforms?

\section{Specific questions}

Why did the government establish Administrative Reform Committee (ARC) in 1987?

How did ARC construct the problems which it recommended for fixing?

How and why did it derive its recommendations?

Why have the ARC recommendations not been fully implemented?

How and why have some of its recommendations been implemented?

Why didn't ARC prioritise its recommendations for implementation with an implementation plan?

Why did ARC recommend setting up a separate Ministry for the public service ignoring the Ministry of Public Administration that existed during that time?

One of the key recommendations was the re-establishment of a Public Service Commission. The government set up a PSC in 2001, after 15 years. Does it lead to independent and politically neutral public service as you expected? If 'not' why?

One of the other key recommendations was the establishment of a Senior Management Group in the public service. That was never executed. Do you still think that SMG is essential? Why? 
Cont...,

Another key recommendation was the introduction of a performance appraisal system in the public sector. This recommendation was implemented in 1998. Do you think that the present system is effective? If 'not' Why?

Do you think that public sector reform should initiate from governmental reform, if it is to be meaningful and effective? Please elaborate.

Another key recommendation was to introduce a scientific manpower planning system in the public sector. This was never executed. Why?

The other key recommendation was to introduce National Training Policy for the public sector. This was never implemented. Do you think that this recommendation is still valid? If 'yes' why?

In report No. 6 you argued that the devolution of administrative authority to subnational level would enable public to exercise authority over planning, management, and evaluation of activities which contribute to their development and well-being. Do you see this rhetoric in practice today? If 'not' why?

In the same report you recommended that there should be clear cut demarcation of functions and development sectors between the centre and the province, the size of the concurrent list should be kept to a minimum and the use of financial relationship as a control mechanism should be avoided. Do you think that these recommendations were adequately considered in the devolution? If 'not' why? What were the impacts of non-implementation of these recommendations?

What is your overall view on the Provincial Council System in SL?

The ARC Report No 7 highlighted a number of deficiencies in the administrative system owing to large number of ministries, departments, and non-departmental organisations. Do you see any difference today in this context? Please elaborate.

In your report No. 9 you made several recommendations to improve the work systems in the public sector. One of the key recommendations was to enhance the use of information technology in the public sector. Do you see any progress in this regard? Please elaborate.

Why are there still so many problems in the Sri Lankan public administration despite various approaches to reform? Why and how have key historical, structural, sociological economic and political factors since independence contributed to the current situation? 


\section{Questionnaire to other interviewees}

Note: Questions were selected and posed from the following according to the individual interviewee's experience on reform

Are you aware of the administrative reform initiatives in Sri Lanka since independence? What are they? What were the primary motivations (drivers) for administrative reforms? Who were the architects? Where did reform ideas come from? Why were they chosen for implementation? What have been their impacts? What has been accomplished?

Were they really the most important things that should have been reformed?

Are there others that are more important? Why are they more important?

Why are there so many problems in the SL public administration despite various approaches to reforms? Why and how have key historical, structural, sociological, economic and political factors since independence contributed to the current situation?

What sort of administrative reforms attract the most attention by the media, and political and other societal groups in SL and Why?

What have been the major obstacles to implementing public administrative reform in SL?

Can public sector reform be independent from governmental reform?

In what way are public administrative and constitutional reforms linked in Sri Lanka?

Why have the goals of $17^{\text {th }}$ Amendment to the Constitution not been achieved yet?

Overstaffing, corruption, inadequate delegation of authority to periphery, and large number of ministries, departments and public enterprises are the key issues in the public sector today. Can you expect efficient public service without addressing these issues properly? Please comment

What kind of governance problems do you see in SL's public administration? Please elaborate.

Empirical evidence suggests that the government regulations or other measures in relation to privatised public enterprises are not sufficient enough. What is your view? Please elaborate

What do you perceive about the recent reform initiatives of enactment of Fiscal Responsibility Act and creation of the Assistant Management Service in the public sector? 


\section{Appendix 3: Interviewees (in alphabetical order)}

\begin{tabular}{|c|c|c|c|c|}
\hline & Name & Position & Category & $\begin{array}{l}\text { Dates of } \\
\text { interview }\end{array}$ \\
\hline 1 & Dr. H.A.P. Abeywardene & $\begin{array}{l}\text { Former Government } \\
\text { Agent and Senior } \\
\text { Lecturer PIM }\end{array}$ & $\begin{array}{l}\text { Public } \\
\text { official cum } \\
\text { Academic }\end{array}$ & $\begin{array}{l}22.11 .2007 \\
22.12 .2007 \\
15.02 .2008 \\
\end{array}$ \\
\hline 2 & Mr. S. Abeysinghe & $\begin{array}{l}\text { Deputy Secretary to } \\
\text { Treasury }\end{array}$ & $\begin{array}{l}\text { Public } \\
\text { official }\end{array}$ & 24.01 .2008 \\
\hline 3 & Mr. J. Abeywickrama & $\begin{array}{l}\text { Secretary, Ministry } \\
\text { of Plantation } \\
\text { Industries }\end{array}$ & $\begin{array}{l}\text { Public } \\
\text { official }\end{array}$ & $\begin{array}{l}26.11 .2007 \\
03.12 .2007\end{array}$ \\
\hline 4 & Mr. D. Amarasinghe, & $\begin{array}{l}\text { Former Secretary and } \\
\text { current Advisor to } \\
\text { the President }\end{array}$ & $\begin{array}{l}\text { Public } \\
\text { official }\end{array}$ & $\begin{array}{l}14.11 .2007 \\
10.12 .2007\end{array}$ \\
\hline 5 & $\begin{array}{l}\text { Hon. Imthias } \quad \text { Bakeer } \\
\text { Marker }\end{array}$ & $\begin{array}{l}\text { Former Minister, } \\
\text { Post, } \\
\text { Telecommunications } \\
\text { and Media }\end{array}$ & Political & 05.01 .2008 \\
\hline 6 & Hon. Ronnie De Mel & $\begin{array}{l}\text { Former Minister, } \\
\text { Finance and Planning }\end{array}$ & Political & $\begin{array}{l}05.12 .2007 \\
19.12 .2007 \\
\end{array}$ \\
\hline 7 & Mr. Andrew De Silva & $\begin{array}{l}\text { Former Secretary, } \\
\text { Ministry of } \\
\text { Education }\end{array}$ & $\begin{array}{l}\text { Public } \\
\text { official }\end{array}$ & $\begin{array}{l}07.11 .2007 \\
13.11 .2007\end{array}$ \\
\hline 8 & Mr. D. Dissanayaka & $\begin{array}{l}\text { Secretary, Ministry } \\
\text { of Public } \\
\text { Administration }\end{array}$ & $\begin{array}{l}\text { Public } \\
\text { official }\end{array}$ & 04.01 .2008 \\
\hline 9 & Dr. Lloyd Fernando, & $\begin{array}{l}\text { Former State } \\
\text { Secretary, State } \\
\text { Ministry of Plan } \\
\text { Implementation }\end{array}$ & $\begin{array}{l}\text { Public } \\
\text { official }\end{array}$ & 06.01 .2008 \\
\hline 10 & Mr. Lionel Fernando & $\begin{array}{l}\text { Co-chair, Salaries } \\
\text { and Cadre } \\
\text { Commission }\end{array}$ & $\begin{array}{l}\text { Public } \\
\text { official }\end{array}$ & 22.01 .2008 \\
\hline 11 & Mrs. H.D.L.Goonewardene & $\begin{array}{l}\text { Secretary, Public } \\
\text { Service Commission }\end{array}$ & $\begin{array}{l}\text { Public } \\
\text { official }\end{array}$ & 11.02 .2008 \\
\hline 12 & Mr. A.P. Gunasekara & $\begin{array}{l}\text { Secretary, Ministry } \\
\text { of Petroleum, and } \\
\text { Petroleum Resource } \\
\text { Development }\end{array}$ & $\begin{array}{l}\text { Public } \\
\text { official }\end{array}$ & $\begin{array}{l}21.11 .2007 \\
30.11 .2007 \\
03.01 .2008\end{array}$ \\
\hline 13 & Mr. Asoka Gunawardene & $\begin{array}{l}\text { Chairman, Finance } \\
\text { Commission }\end{array}$ & $\begin{array}{l}\text { Public } \\
\text { official }\end{array}$ & 07.01 .2008 \\
\hline 14 & Mr. Vijitha Herath & MP & Political & 18.01 .2008 \\
\hline 15 & Mr. Daya Liyanage & $\begin{array}{l}\text { Former Deputy } \\
\text { Secretary to the } \\
\text { Treasury }\end{array}$ & $\begin{array}{l}\text { Public } \\
\text { official }\end{array}$ & $\begin{array}{l}02.01 .2008 \\
07.01 .2008\end{array}$ \\
\hline
\end{tabular}




\begin{tabular}{|c|c|c|c|c|}
\hline & Name & Position & Category & $\begin{array}{l}\text { Dates of } \\
\text { interview }\end{array}$ \\
\hline 16 & Mr. V.K. Nanayakkara & $\begin{array}{l}\text { Former Secretary, } \\
\text { Ministry of } \\
\text { Education }\end{array}$ & $\begin{array}{l}\text { Public } \\
\text { official }\end{array}$ & $\begin{array}{l}06.11 .2007 \\
14.11 .2007\end{array}$ \\
\hline 17 & Mr. N. Pathmanathan & $\begin{array}{l}\text { Former Deputy } \\
\text { Secretary to the } \\
\text { Treasury }\end{array}$ & $\begin{array}{l}\text { Public } \\
\text { official }\end{array}$ & $\begin{array}{l}26.11 .2007 \\
02.01 .2008\end{array}$ \\
\hline 18 & Hon. S. Premajayantha & $\begin{array}{l}\text { Minister of } \\
\text { Education }\end{array}$ & Political & 19.02 .2008 \\
\hline 19 & Dr. S.W. Ranasinghe & $\begin{array}{l}\text { Professor, Open } \\
\text { University of Sri } \\
\text { Lanka }\end{array}$ & Academic & 11.12 .2007 \\
\hline 20 & Mr. S. Ranugge & $\begin{array}{l}\text { Secretary, Ministry } \\
\text { of Export } \\
\text { Development and } \\
\text { International Trade }\end{array}$ & $\begin{array}{l}\text { Public } \\
\text { official }\end{array}$ & 09.11 .2007 \\
\hline 21 & Mr. Susil Sirivardana & $\begin{array}{l}\text { Former } \\
\text { Commissioner }\end{array}$ & $\begin{array}{l}\text { Public } \\
\text { official }\end{array}$ & 22.11 .2007 \\
\hline 22 & Mr. M. Somasundram & $\begin{array}{l}\text { Former Director } \\
\text { General }\end{array}$ & $\begin{array}{l}\text { Public } \\
\text { official }\end{array}$ & $\begin{array}{l}11.12 .2007 \\
17.12 .2007\end{array}$ \\
\hline 23 & Mr. H.S. Wanasinghe & $\begin{array}{l}\text { Chair of the } \\
\text { Administrative } \\
\text { Reforms Committee } \\
\text { of } 1986 / 88\end{array}$ & $\begin{array}{l}\text { Public } \\
\text { official }\end{array}$ & $\begin{array}{l}09.11 .2007 \\
02.12 .2007 \\
31.12 .2007 \\
08.01 .2008\end{array}$ \\
\hline 24 & Mr. Bradman Weerakoon & $\begin{array}{l}\text { Former Secretary to } \\
\text { the Prime Minister } \\
\text { (1956-1970, 2001- } \\
\text { 2004) }\end{array}$ & $\begin{array}{l}\text { Public } \\
\text { official }\end{array}$ & $\begin{array}{l}15.11 .2007 \\
20.11 .2007 \\
30.11 .2007\end{array}$ \\
\hline 25 & Mr. K.H.J. Wijayadasa & $\begin{array}{l}\text { Former Secretary to } \\
\text { the Prime Minister } \\
\text { and the President } \\
(1984-1994)\end{array}$ & $\begin{array}{l}\text { Public } \\
\text { official }\end{array}$ & $\begin{array}{l}10.12 .2007 \\
27.12 .2007 \\
11.01 .2008\end{array}$ \\
\hline 26 & Mr. W.G. Wijerathna & $\begin{array}{l}\text { Additional Secretary, } \\
\text { Ministry of } \\
\text { Plantation Industries }\end{array}$ & $\begin{array}{l}\text { Public } \\
\text { official }\end{array}$ & $\begin{array}{l}03.12 .2007 \\
13.12 .2007\end{array}$ \\
\hline 27 & Mr. D. Wijesinghe & $\begin{array}{l}\text { Secretary to the } \\
\text { Cabinet }\end{array}$ & $\begin{array}{l}\text { Public } \\
\text { official }\end{array}$ & $\begin{array}{l}12.11 .2007 \\
19.11 .2007\end{array}$ \\
\hline 28 & Dr. B.S. Wijeweera & $\begin{array}{l}\text { Former Government } \\
\text { Agent }\end{array}$ & $\begin{array}{l}\text { Public } \\
\text { official cum } \\
\text { academic } \\
\end{array}$ & 09.01 .2008 \\
\hline
\end{tabular}

In addition to above key respondents, the following officials were also interviewed to gather information on productivity development, investigation of corruptions, the use of IT in public administration and the PCs

Upali Marasinghe - Director, Productivity Secretariat, 27.12.2007

Seetha Fernando, Accountant, Ministry of Provincial Council, 09.01.2008

P. Ranasinghe -Director General, Bribery and Corruption Commission, 28.1.2008 
Wasantha Deshapriya - Director (Re-engineering Governance), ICTA, 28.1.2008 


\section{Appendix 4: Map of SL - Provinces}

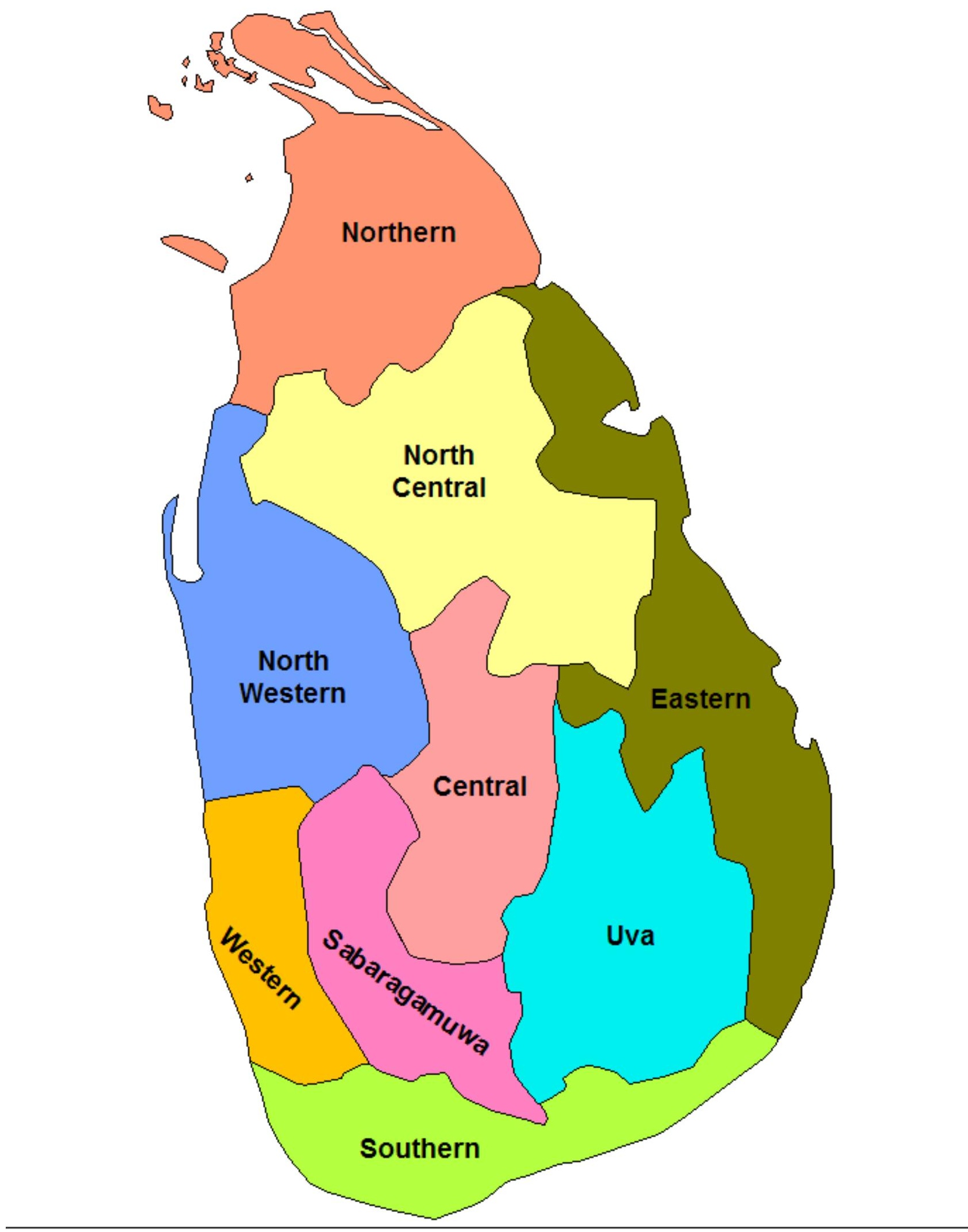




\section{Appendix 5: Map of SL - Districts}

\begin{tabular}{l} 
Legend \\
Vavuniya \\
Trincomalee \\
Ratnapura \\
Puttalam \\
\hline Polonnaruwa \\
\hline Nuwara - Eliya \\
Mullaitivu \\
Monaragala \\
\hline Matara \\
Matale \\
Mannar \\
Kurunegala \\
Killinochchi \\
Kegalle \\
Kandy \\
\hline Kalutara \\
Jaffna \\
Hambantota \\
Gampaha \\
Galle \\
Galombo \\
Batticaloa \\
Badulla \\
Anuradhapura \\
Ampara \\
\hline Amara
\end{tabular}

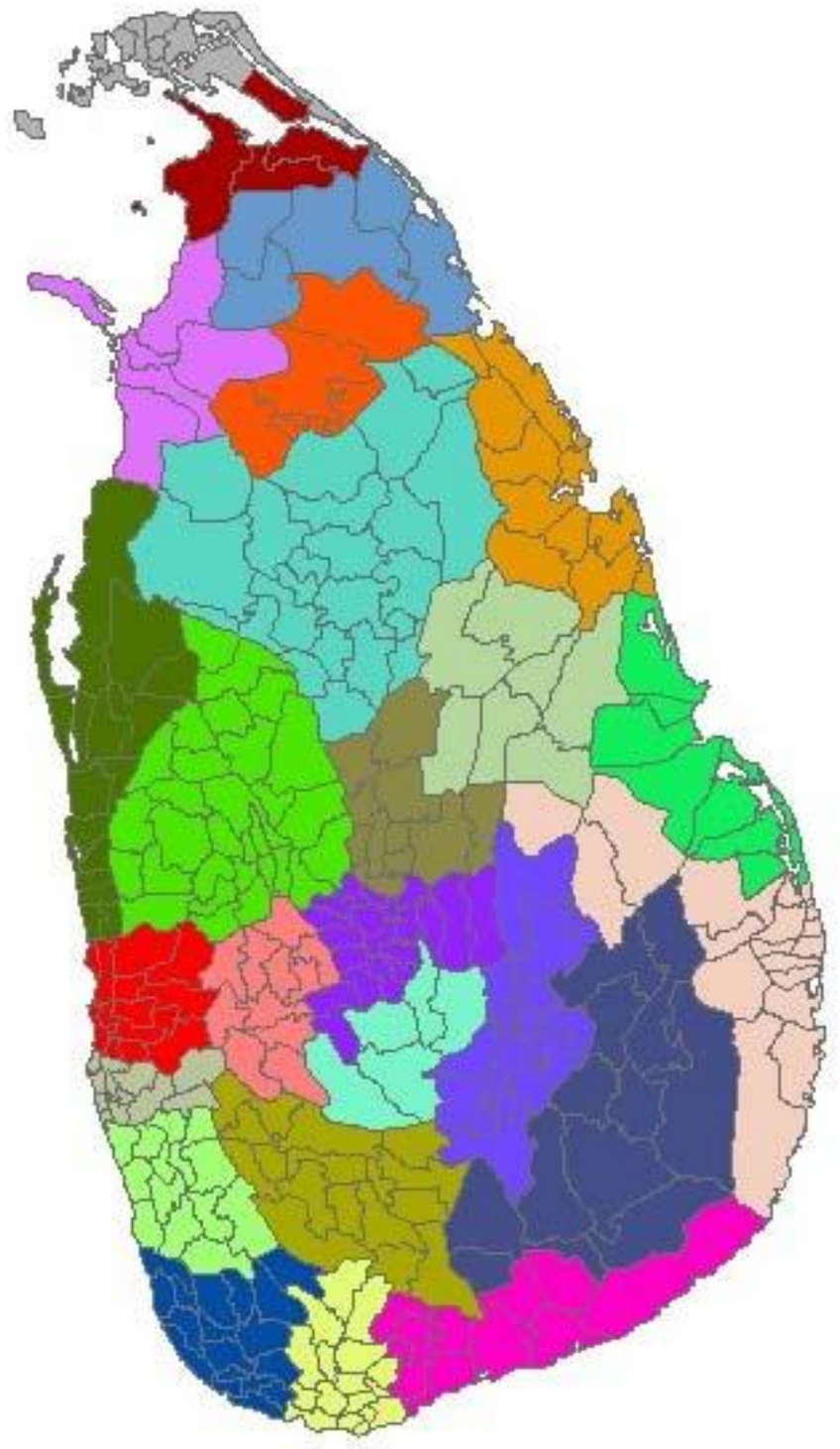




\section{Appendix 6: Administrative Structure}

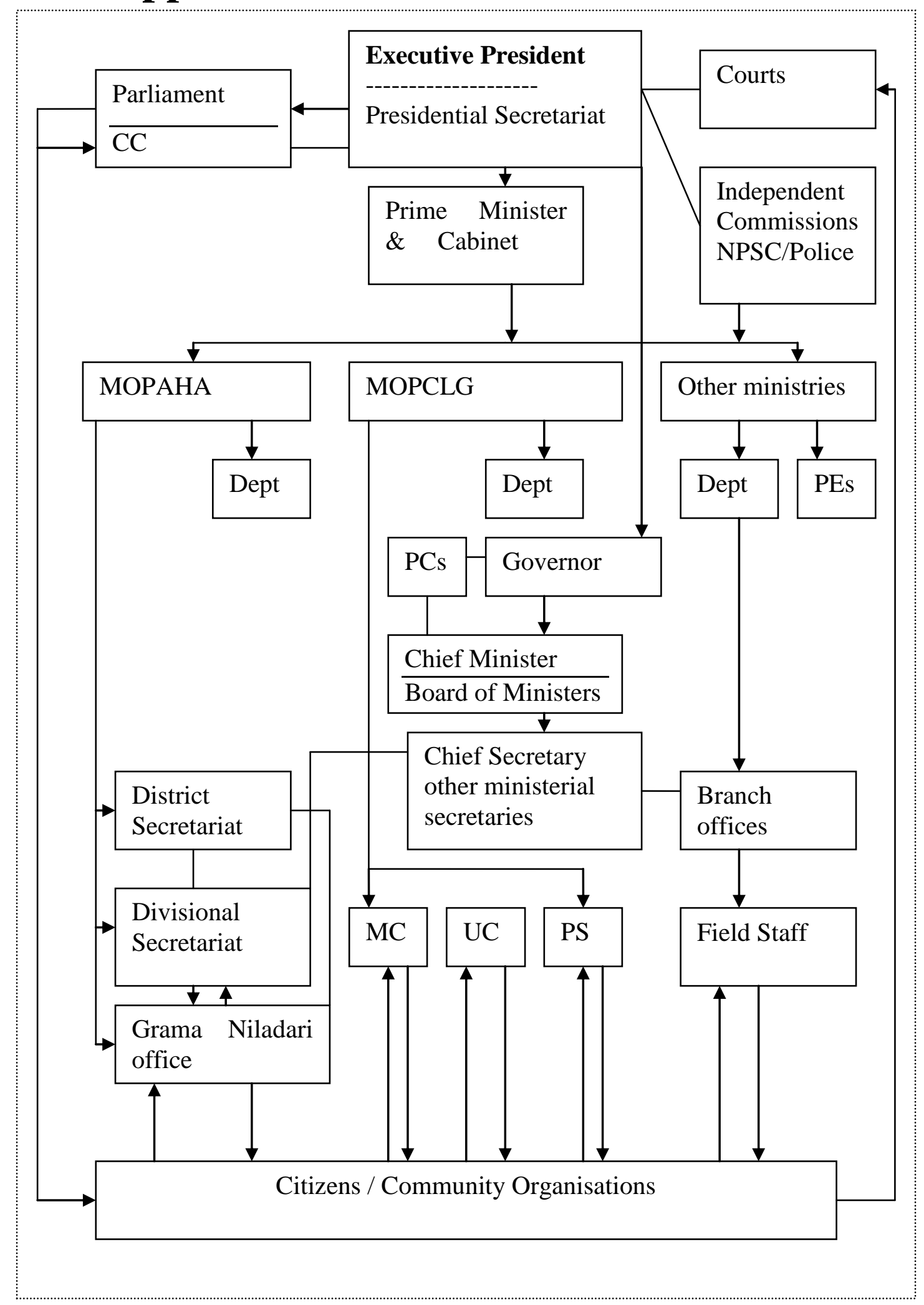

Note: MOPAHA- Ministry of Public Administration and Home Affairs MOPCLG - Ministry of Provincial Council and Local Government

PEs - Public Enterprises; PCs - Provincial Councils; MC - Municipal Council; UC - Urban Council; PS - Pradeshiya Sabha 


\section{Appendix 7: Delegation of Authority of the National Public Service Commission}

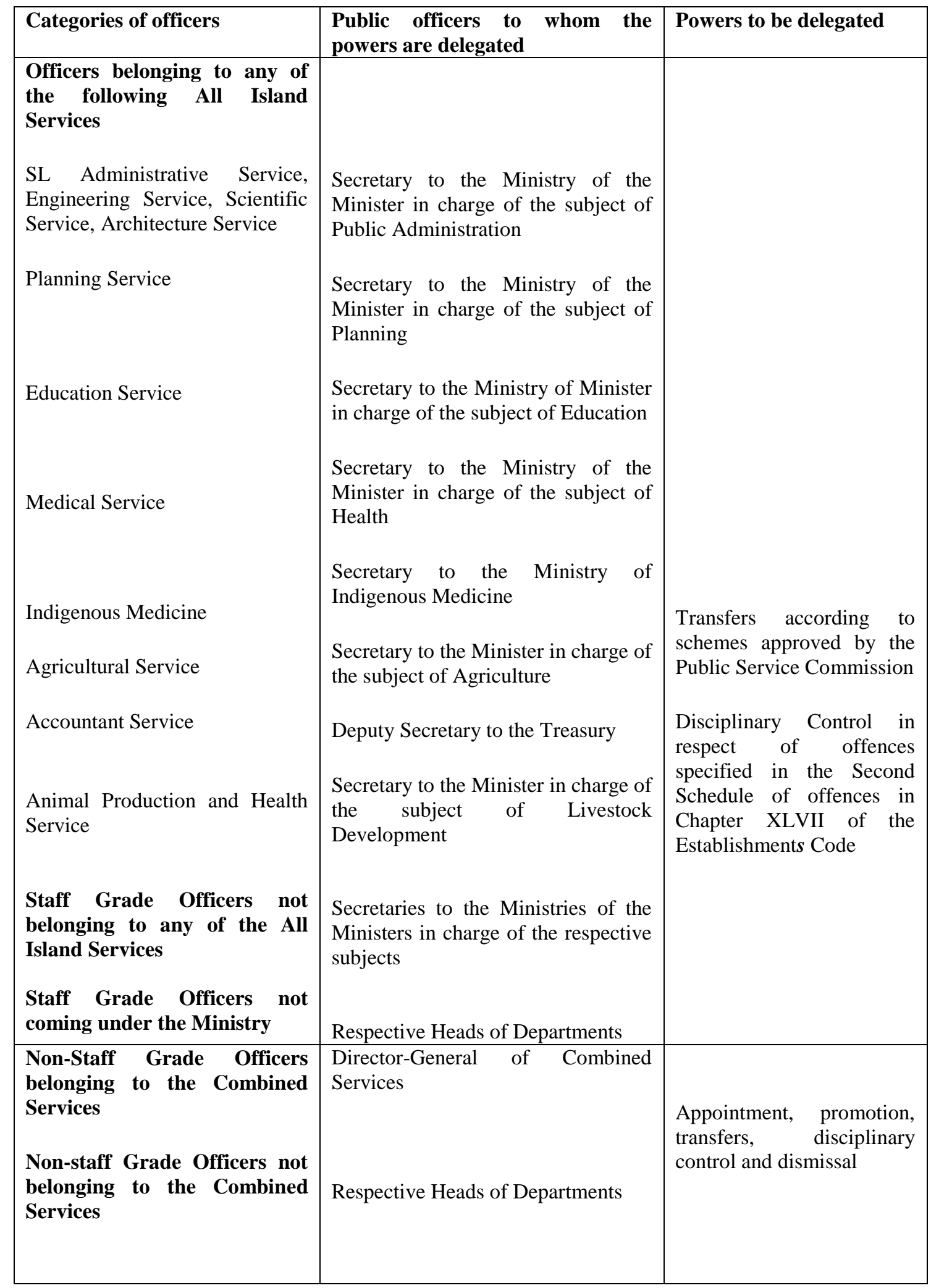

Source: Extraordinary Gazette No. 1295/26 of the Democratic Socialist Republic of SL (2003, July 2) 


\section{Appendix 8: ARC Recommendations}

\section{Implemented Fully or Partially}

\begin{tabular}{|c|c|}
\hline $\begin{array}{l}\text { Key Recommendations } \\
\text { Cadre Management and Salaries }\end{array}$ & Status \\
\hline $\begin{array}{l}\text { Freeze all recruitment for two years and } \\
\text { rationalisation of cadres; } \\
\text { Revise salaries upward; } \\
\text { Link Salaries to cost of living; } \\
\text { Revise salaries to specific posts based on job } \\
\text { classifications; } \\
\text { Reduce number of salary scales. }\end{array}$ & $\begin{array}{l}\text { Set up in 1989, but not } \\
\text { effective. Again in } 2005 \\
\text { Salaries \& Cadre } \\
\text { Commission was } \\
\text { established. } \\
\text { 2001, Partially } \\
\text { implemented } \\
\text { 1989/2006 } \\
2007 \\
\text { Partially }\end{array}$ \\
\hline $\begin{array}{l}\text { Personnel System } \\
\text { Re-establish independent PSC; } \\
\text { Abolish job bank scheme of recruitment; } \\
\text { Introduce open, competitive and merit-based } \\
\text { recruitment; } \\
\text { Decentralise non-staff recruitments; } \\
\text { Formulate job descriptions and scheme of } \\
\text { recruitment for each post; } \\
\text { Introduce performance appraisal system; } \\
\text { Implement transfers at the beginning of the year; } \\
\text { Give three months notice to employee on transfer; } \\
\text { Not to link transfers to disciplinary measures; } \\
\text { Make retirement at the age of } 60 \text { years; } \\
\text { Not to extend service after } 60 \text { years; } \\
\text { Facilitate retirement prior to } 55^{\text {th }} \text { birthday; } \\
\text { Link pension to cost of living index; } \\
\text { Introduce appeal tribunal under PSC. }\end{array}$ & $\begin{array}{l}2001 \text { but defunct in } \\
2005 \\
1990 \\
1990, \text { not for all posts } \\
\text { Partially } \\
\text { After } 2000 \\
1998 \text {, Partially } \\
\text { Partially } \\
\text { Partially } \\
\text { Partially } \\
\text { Partially } \\
\text { Partially } \\
\text { 1990s } \\
\text { 2007 } \\
\text { 2002, Independent body } \\
\text { AAT was established }\end{array}$ \\
\hline $\begin{array}{l}\text { Training } \\
\text { Strengthen the SLIDA; } \\
\text { Release full-time public servants to undergo } \\
\text { postgraduate programmes; } \\
\text { Provide funds for training as a part of the } \\
\text { emoluments of each ministry; } \\
\text { Establish Provincial Public Service Commissions. }\end{array}$ & $\begin{array}{l}\text { Partially } \\
\text { Implemented } \\
\text { Partially } \\
1990\end{array}$ \\
\hline $\begin{array}{l}\text { Devolution } \\
\text { Maximum allocation of operational responsibilities } \\
\text { to provinces; }\end{array}$ & Partially \\
\hline
\end{tabular}




\begin{tabular}{|c|c|}
\hline Key Recommendations & Status \\
\hline $\begin{array}{l}\text { Establish a Finance Commission; } \\
\text { Allocate financial resources based on the devolved } \\
\text { revenue; } \\
\text { Establish Provincial Planning Councils; } \\
\text { Establish Provincial Public Service Commissions. }\end{array}$ & $\begin{array}{l}1988 \\
\text { Partially } \\
1990 s \\
1990 s \\
1990 s\end{array}$ \\
\hline $\begin{array}{l}\text { Rationalisation of Government Functions } \\
\text { Establish a National Planning Council: } \\
\text { Greater delegation of responsibility and authority; } \\
\begin{array}{l}\text { Establish effective mechanism to address public } \\
\text { grievances. }\end{array}\end{array}$ & $\begin{array}{l}1990 \text { s } \\
\text { To some extent through } \\
\text { PCs. } \\
\text { Partially }\end{array}$ \\
\hline $\begin{array}{l}\text { Systems and Procedures } \\
\text { Review and improve work processes in each } \\
\text { organisation; } \\
\text { Improve the office layout to enhance supervision } \\
\text { and monitoring; } \\
\text { Device appropriate work systems and procedures when } \\
\text { new services are launched and when training cadres. }\end{array}$ & $\begin{array}{l}\text { All partially } \\
\text { implemented }\end{array}$ \\
\hline $\begin{array}{l}\text { Financial Management } \\
\text { Streamline paying-in procedures; } \\
\text { Simplify forms and documents; } \\
\text { Shorten payment processes; } \\
\text { Expand the payment outlets; } \\
\text { Adopt continuous reforms to the internal financial } \\
\text { systems; } \\
\text { Establish audit units in ministries and departments at } \\
\text { the centre and the provinces; } \\
\text { Introduce a team of trained professionals in } \\
\text { procurement management; } \\
\text { Give appropriate training to relevant managers on } \\
\text { domestic and international bidding and procurement; } \\
\text { Provide training for all categories of staff handling } \\
\text { financial management; } \\
\text { Review and reform the financial management } \\
\text { system periodically. }\end{array}$ & All partially \\
\hline $\begin{array}{l}\text { Public enterprises } \\
\text { Hold non-governmental organisations accountable } \\
\text { to Parliament through the Public Accounts } \\
\text { Committee; } \\
\text { Apply the 'Sunset' principle (p. 242) strictly to } \\
\text { non-departmental organisations; } \\
\text { Have an operational management board at the top. }\end{array}$ & Partially \\
\hline
\end{tabular}




\section{Appendix 9: ARC Recommendations Not Implemented}

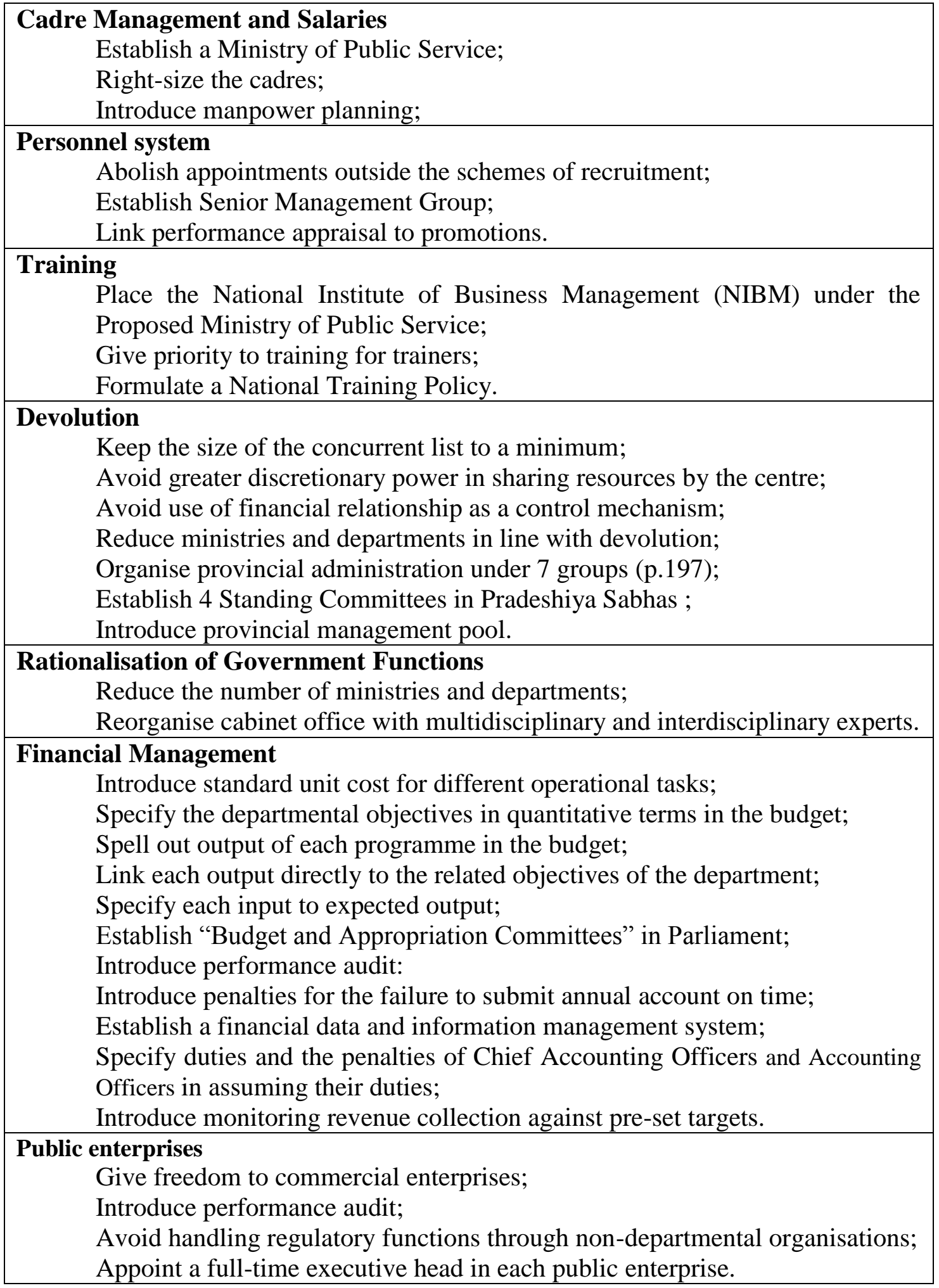

